\title{
ASSÉDIO MORAL ORGANIZACIONAL NOS BANCOS
}

\author{
Dissertação de mestrado \\ Orientador Professor Paulo Eduardo Vieira de Oliveira
}

Universidade de São Paulo

Faculdade de Direito

São Paulo

2012 


\section{ASSÉDIO MORAL ORGANIZACIONAL NOS BANCOS}

Dissertação de mestrado apresentada à Banca Examinadora da Faculdade de Direito da Universidade de São Paulo como requisito parcial para a obtenção do título de Mestre em Direito do Trabalho elaborada sob a orientação do Professor Paulo Eduardo Vieira de Oliveira. 


\section{ASSÉDIO MORAL ORGANIZACIONAL NOS BANCOS}

Dissertação de mestrado apresentada à Banca Examinadora da Faculdade de Direito da Universidade de São Paulo como requisito parcial para a obtenção do título de Mestre em Direito do Trabalho.

Data da Banca:

Nome:

Título:

Instituição:

Nome:

Título:

Instituição:

Nome:

Título:

Instituição: 


\section{Agradecimentos}

Primeiramente, gostaria de agradecer ao povo brasileiro que inspirou e garantiu os estudos que resultaram nessa dissertação através de uma universidade estadual e uma bolsa de estudos federal. Educação pública, gratuita e de qualidade que, infelizmente, ainda é restrita a uma minoria e carece de universalização.

À classe trabalhadora e à categoria bancária, em especial ao Sindicato dos Bancários do ABC, cujas lutas e organizações inspiraram este trabalho.

Ao meu Orientador Paulo Eduardo Vieira de Oliveira, que me possibilitou elaborar essa obra com seus ensinamentos na sala de aula e fora dela, concedendo-me liberdade e oportunidades.

Ao Professor Jorge Luiz Souto Maior, pessoa fundamental desde o início e para o desenrolar dessa trajetória na FDUSP, e ao Professor Homero Batista pelas contribuições ofertadas na qualificação e aproveitadas nessa dissertação.

A minha família que, suportando a saudade causada pela distância, torce por mim. O banzo daqui de longe é muito forte.

A meus amigos que deixei na Bahia ou que também foram pra longe e os que ganhei aqui. Tamo junto.

A Vinícius, Anderson, Carla, Mateus, Arendra, Dalila e Filipe, fundamentais em minha chegada a São Paulo.

A Bruno pelos comentários precisos, mormente o das "humanas", e a João, que fez questão de contribuir com o abstract, resúmen e résumé.

A Gilberto Gil, cuja melodia perfumava a tarde enquanto essas palavras eram escritas.

A Andrea, meu grande amor, que me ensinou como é boa a vida a dois e como é bom se entregar a uma paixão. Minha vida com você é um eterno carnaval.

À Bahia, que me deu régua e compasso. 
Em vez de falar em crise e em desordem, que são os temas preferidos da classe dominante brasileira na sua tradição autoritária, é hora de comemorarmos o fato de que finalmente este país está conhecendo uma experiência democrática. Democracia não é, como querem os liberais, o regime da lei e da ordem. Democracia é o único regime político no qual os conflitos são considerados o princípio mesmo do seu funcionamento.

Marilena Chauí

Gosto de atrito. É a base do sexo.

Caetano Veloso 


\section{RESUMO}

O presente trabalho tem por escopo constatar a existência generalizada do assédio moral em sua modalidade organizacional nos bancos e analisar como o movimento sindical da categoria bancária enfrenta o problema para poder perceber que as negociações coletivas são o palco adequado para resolver o problema. A apreensão jurídica do assédio moral organizacional, a análise transdisciplinar de sua ocorrência nos bancos e a crítica às negociações coletivas no Brasil e no setor serão analisados para que se visualize a hipótese.

Palavras-chaves: assédio moral organizacional, bancos, organização sindical bancária, democracia, negociações coletivas 


\begin{abstract}
The present work aims to state the generalized existence of moral harassment in its organizational version in banks and to analyze how the trade union movement of bank employees faces the problems in order to be able to perceive that collective negotiations are the adequate stage to solve the problem. The juridical apprehension of organizational moral harassment, the transdisciplinary analysis of its occurrence in banks and the criticizing of collective negotiations in Brazil and in bank sector will be analyzed so as to verify the hypothesis.
\end{abstract}

Keywords: organizational moral harassment, banks, bank employees' trade union organization, democracy, collective bargaining 


\section{RESÚMEN}

Este trabajo tiene como objetivo constatar la existencia generalizada del acoso moral en su modalidad organizacional en los bancos y analizar como el movimiento sindical de la categoría bancaria enfrenta el problema para poder percibir que las negociaciones colectivas son el escenario adecuado para resolver el problema. La aprehensión jurídica del acoso moral organizacional, el análisis transdisciplinar de su ocurrencia en los bancos y la crítica a las negociaciones colectivas en Brasil y en el sector serón analizadas para que se verifique la hipótesis.

Palabras clave: acoso moral organizacional, bancos, organización sindical bancaria, democracia, negociaciones colectivas 


\section{RÉSUMÉ}

Ce travail a pour objectif de constater l'existence généralisée du harcèlement moral dans sa modalité organisationnelle aux banques et d'analyser comment le mouvement syndical de la catégorie bancaire se trouve face à ce problème, pour pouvoir s'apercevoir que les négociations collectives sont la scène adéquate pour le résoudre. L'appréhension juridique du harcèlement moral organisationnel, l'analyse transdisciplinaire de son occurrence dans les banques e la critique aux négociations collectives au Brésil et dans le secteur seront analysées pour que l'hypothèse soit verifiée.

Mots clés: harcèlement moral organisationnel, banques, organisation syndicale bancaire, démocratie, négociations collectives 


\section{SUMÁRIO}

1. INTRODUÇÃO. .12

2. O ASSÉdio MORAL ORgANIZACIONAL E SUA RECEPÇÃO PELO

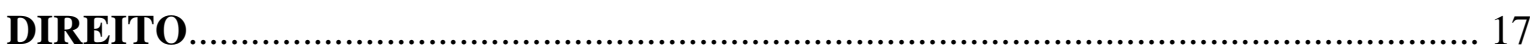

2.1. Os Estudos Iniciais sobre o Assédio Moral no Trabalho..............................................17

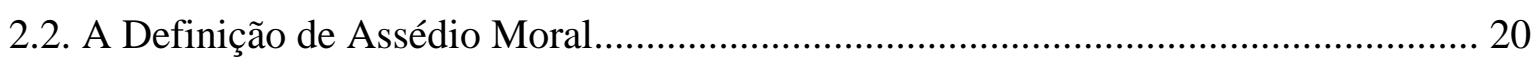

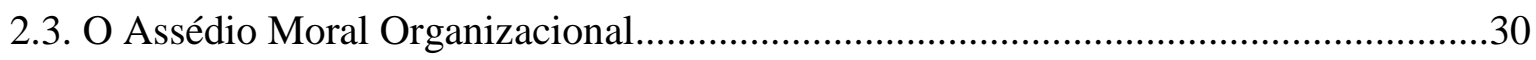

2.4. Os Fundamentos do Assédio Moral Organizacional......................................................37

2.4.1. O controle subjetivo do trabalhador - fundamento subjetivo...................................40

2.4.2. A quantificação do trabalho e as avaliações das metas ou o aumento da

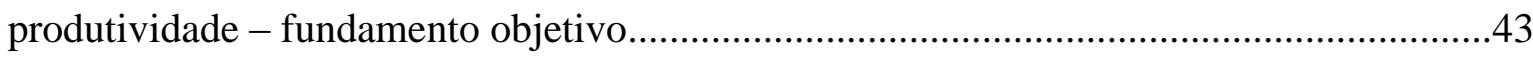

2.5. A Apreensão Jurídica do Assédio Moral.......................................................................49

2.6. O Assédio Moral Organizacional Captado pelo Direito Brasileiro................................52

2.7. Os Fundamentos Jurídicos do Assédio Organizacional...............................................77

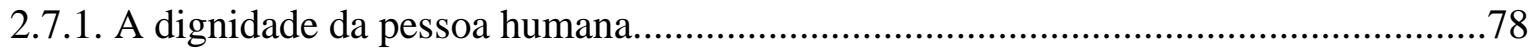

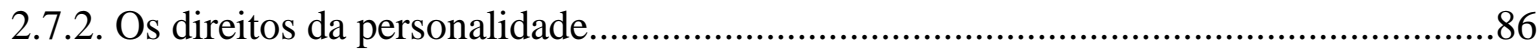

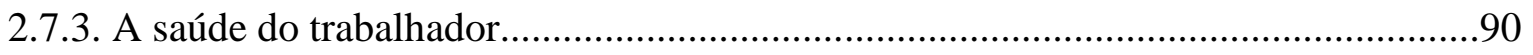

3. O ASSÉDIO MORAL ORGANIZACIONAL NOS BANCOS...............................96

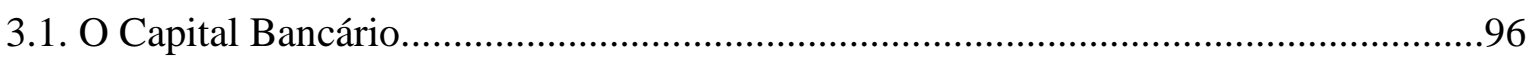

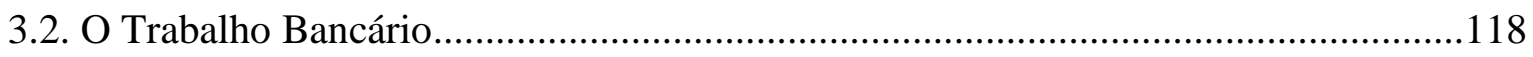

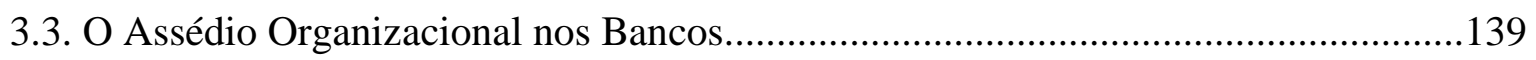

3.3.1. A base subjetiva do assédio moral organizacional nos bancos...............................141

3.3.2. A base objetiva do assédio moral organizacional nos bancos................................... 146

3.3.3. Decorrências do assédio moral organizacional no setor bancário............................155

3.3.4. Ações judiciais comuns à categoria bancária a comprovar o assédio moral organizacional nos bancos

4. A LUTA SINDICAL É O MEIO ADEQUADO A RESOLVER O PROBLEMA DO

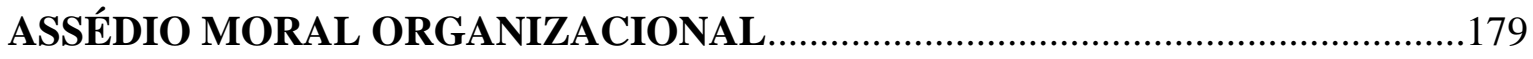

4.1. O Problema das Negociações Coletivas no Brasil....................................................179

4.2. A Organização Sindical Bancária e a Superação do Assédio Moral............................233

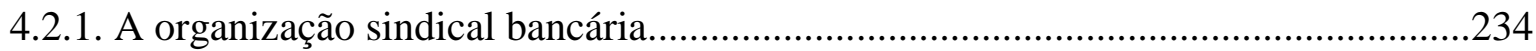

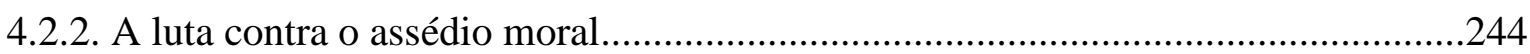


5. CONCLUSÃO

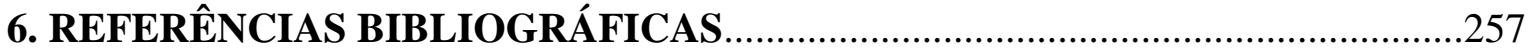

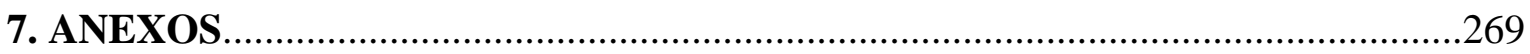




\section{INTRODUÇÃO}

Essa dissertação é uma defesa da mais ampla, plena e irrestrita liberdade sindical.

Os sindicatos representam um dos elementos mais importantes para a consolidação da democracia em qualquer país e em qualquer momento da história do capitalismo. A organização coletiva dos trabalhadores em defesa de seus interesses permitiu que à sociedade dar um salto de qualidade humanista na medida em que a busca pelo acúmulo de riquezas encontrou um contraponto calcado no ser humano.

O capital e as empresas capitalistas visam o lucro e nada mais. Se encontram liberdade de atuação, destroem tudo e todos em nome da acumulação. Destroem os seres humanos que para as empresas trabalham e colocam outros no lugar, levam a países inteiros a entrarem em guerra e se destruíram mutuamente, enriquecem uns poucos e mantem milhões na mais impiedosa miséria. Assim também é o capital bancário.

Os bancos e demais instituições financeiras concentraram o capital produzido pelas indústrias para depois submeter as próprias indústrias e demais atividades econômicas. Surgiram para financiar a economia, mas hoje é a economia que financia os bancos.

Nas últimas décadas, as instituições financeiras adquiriram centralidade na economia global. Os desarranjos sociais produzidos foi a consequência nefasta dessa hegemonia. O preço maior pela acumulação de riquezas que nada produzem e se valorizam apenas pelos juros é pago pela força de trabalho bancária.

No Brasil, o trabalho nos bancos sofreu fortes transformações a partir dos anos 1990 que criou um quadro de destruição física e mental dos empregados. Os novos modelos de gestão transformaram o bancário em um vendedor e sobre eles pesa a responsabilidade pelo sucesso ou fracasso da empresa. O Direito do Trabalho afirma que cabe ao empregador os riscos do negócio. Os bancos desvirtuaram por completo essa afirmação.

A atividade bancária é extremamente relacional. O resultado do negócio não depende apenas do empregado, mas depende fundamentalmente do cliente. É este quem decide o que é melhor pra si, qual produto adquirir, qual serviço lhe interessa. Mas os bancos desconsideram por completo as peculiaridades de uma atividade de serviços e impõem metas de produtividade aos seus empregados. 
O empregado bancário tem metas de vendas de cartões, metas de seguros, metas de previdência, metas de títulos de capitalização, metas de consórcio, metas, metas, metas. Sua avaliação resume-se a um número: o quanto ele produziu. Ou o quanto o banco queria que ele tivesse produzido. Do cumprimento das metas depende o seu salário, a sua promoção, o seu emprego.

Ele dorme pensando nas metas, sonha com as metas, acorda pensando nas metas. Em sua jornada diária, será cobrado duas, três, dez vezes pelo que já vendeu e pelo que não vendeu. E cada oportunidade deve ser aproveitada: uma reunião com amigos, um almoço em família, um fim de semana no clube, sempre haverá uma chance de vender um produto ou um serviço. O bancário vive metas.

A essa situação de violência organizacional, o Poder Judiciário assiste impassível. A Constituição assegura a dignidade, a personalidade e a saúde dos trabalhadores. O assédio moral organizacional nos bancos é latente, mas há dificuldades em repeli-lo. A tradição jurídica brasileira é de leis minuciosas e interpretações silogísticas. Mas o assédio moral envolve alta carga de subjetividade e valoração, incomuns na processualística nacional.

Uma sentença que defira horas extras liquida-se pelo simples cálculo da quantidade de horas trabalhadas ou de uma estimativa. Mas quanto vale uma tendinite que impede a pessoa até de escrever seu nome? Quanto custa uma depressão? Dores de cabeça constantes? Qual o valor a se pagar a um indivíduo que passa o fim de semana trancado no quarto, longe do convívio social? Nas faculdades de direito, ensina-se que a condenação por assédio deve observar as condições econômicas do reclamado. Sendo assim, como explicar uma condenação de R 10 mil a uma empresa que lucra R 10 bilhões em um ano?

A superação do assédio organizacional nos bancos só poderá ser protagonizada pelos bancários e suas lutas sindicais. Para isso lutarão contra um poderoso conglomerado econômico ao passo em que lutarão contra uma legislação que lhe nega a liberdade de se organizar e agir. A Constituição de 1988 manteve os elementos centrais corporativistas de intervenção nos sindicatos: unicidade imposta, contribuição compulsória, base territorial municipal mínima, estrutura vertical, organização por categoria. Corporativismo esse que choca-se com a liberdade conquistada pelos países de capitalismo avançado e defendida pela OIT. 
A liberdade sindical é de extrema importância desde que o capitalismo generalizou o trabalho assalariado subordinado. São os trabalhadores que enriquecem as empresas e cabe a estes definir os seus destinos e suas condições de labor. A autonomia privada coletiva é absolutamente necessária enquanto o trabalho social for alienado, apropriado por outrem. Dois personagens históricos em dois momentos históricos distintos confirmam essa tese.

Em 1922, a URSS consolidava-se após quatro anos de devastadora guerra civil. Boa parte das empresas foram estatizadas, socializadas ou transformadas em cooperativas. A revolução e o Estado pretendiam-se proletários mas, mesmo nessa sociedade que estaria nas mãos dos trabalhadores, o líder russo Vladimir Ilitch Ulianov pregava a liberdade dos trabalhadores organizarem-se coletivamente em defesa de seus interesses imediatos contra as empresas.

\footnotetext{
No que diz respeito às empresas socializadas, recai incondicionalmente sobre os sindicatos a obrigação de defender os interesses dos trabalhadores, de contribuir, na medida do possível, para melhorar suas condições materiais de existência, corrigindo constantemente os erros e os exageros nos organismos econômicos, de vez que estes erros e exageros derivam-se da deformação burocrática do aparelho do Estado (LENIN, 1979, 315/6).
}

A Revolução Russa era a primeira grande experiência de socialização da economia e assunção da classe trabalhadora ao poder. Mesmo nessas circunstâncias, Ulianov defendia a autonomia dos sindicatos, sua liberdade e seu direito de ação livre em defesa dos trabalhadores. No mesmo texto, é defendida a filiação voluntária dos empregados por exemplo.

Meio século depois no Brasil, Luiz Inácio da Silva seria eleito presidente do Sindicato dos Metalúrgicos do ABC em plena ditadura militar e auge da Guerra Fria. Seu discurso de posse na presidência do sindicato em 1975 constatava que a humanidade vivia um dos mais obscuros momentos para os destinos individuais e coletivos da história.

De um lado vemos o homem esmagado pelo Estado, escravizado pela ideologia marxista, tolhido nos seus mais comezinhos ideais de liberdade, limitado em sua capacidade de pensar e se manifestar. E no reverso da situação, encontramos o homem escravizado pelo poder econômico explorado por outros homens, privados da dignidade que o trabalho proporciona, tangidos pela febre do lucro, 
jungidos ao ritmo louco da produção, condicionados por leis bonitas mas inaplicáveis, equiparados às máquinas e ferramentas (apud RAINHO, BARGAS, 1983, p. 187).

O líder operário constatava que a defesa da liberdade sindical do líder russo não surtira efeito e o Estado soviético prevaleceu sobre os trabalhadores. Por outro lado, o capitalismo polarizava com a opressão do mercado e escravizava os trabalhadores perante as estruturas econômicas. Qualquer que fosse o modelo de sociedade adotado, havia opressão e Silva preconizava que "somente pela nossa própria ação conseguiremos atingir os objetivos almejados pela classe que representamos" (apud RAINHO, BARGAS, 1983, p. 188).

O que Lênin e Lula afirmaram em momentos e países tão diversos era o mesmo: a livre ação sindical e a autonomia privada coletiva são fundamentais para que os trabalhadores negociem as condições de seu trabalho e decidam os seus destinos. Em linguagem jurídica, para que obtenham a dignidade individual e coletiva. A análise da organização sindical bancária e de suas mais recentes convenções coletivas comprovam essa tese.

Os bancos reformaram a gestão de seus recursos humanos ao longo dos últimos anos acarretando uma série de problemas aos bancários. A despeito das amarras corporativistas que perduram, o Brasil vive o seu mais longo período democrático e as sucessivas campanhas contra o assédio moral e as metas abusivas começam a dar os primeiros resultados. Acompanhar a concretização desses direitos através das negociações coletivas é o objeto desse trabalho, que será dividido em três partes.

A primeira parte analisará a absorção, pelo Direito, do instituto do assédio moral organizacional. O assédio é um fato social que antecede o direito. Sua percepção inicial foi captada pelas chamadas ciências do trabalho e só então a legislação social pôde lhe repelir. Será analisado como distinguem-se o assédio interpessoal do organizacional e quais bens jurídicos tutelados pelo direito brasileiro são atacados.

Em seguida, será analisado o capital bancário em perspectiva histórica e o seu duplo negativo, o trabalho bancário. Buscar-se-á compreender como a tensão que os vincula engendra o assédio organizacional. Para isso, serão utilizados necessários conceitos transdisciplinares e informações quantitativas e qualitativas que permitam a visualização do assédio. 
Por fim, far-se-á uma crítica ao ordenamento jurídico vigente no que diz respeito ao modelo sindical corporativista que ainda perdura em detrimento da liberdade sindical. Será analisado como as negociações coletivas ocorrem no Brasil e como a legislação sindical demanda urgente reforma democrática. A par disso, observar-se-á a organização sindical bancária, suas convenções coletivas e o como o combate ao assédio moral organizacional começa a surtir os primeiros efeitos.

Há uma percepção por parte da doutrina de que as negociações coletivas são o melhor caminho para regulamentar os conflitos entre capital e trabalho e a Universidade de São Paulo não foge à regra. Nesse ínterim, essa dissertação pretende apresentar uma análise jurídica geral do assédio organizacional e uma crítica ao direito coletivo vigente, a partir da análise de um conflito específico que ocorre nos bancos, um tão importante setor econômico, para que sirva de exemplo da importância e urgência da democratização das relações de trabalho no Brasil. 


\section{O ASSÉDIO MORAL ORGANIZACIONAL E SUA RECEPÇÃO PELO DIREITO}

O presente capítulo tem por escopo compreender o fenômeno do assédio moral em geral e do assédio moral organizacional em particular. Será abordado o tema em perspectiva histórica, observando como os primeiros estudos e reações ao problema se desenvolveram e como as chamadas ciências do trabalho o trataram.

A partir do domínio dos conceitos que envolvem a problemática, analisar-se-á como o Direito apreendeu o fenômeno, primeiro nos ordenamentos jurídicos dos países de capitalismo avançado, até chegar ao Brasil que, embora não disponha de uma lei específica sobre o tema, absorveu-lhe através de uma interpretação sistemática da legislação vigente.

2.1 Os Estudos Iniciais Sobre o Assédio Moral No Trabalho

Todos os estudos acerca da problemática do assédio moral apontam para Heinz Leymann como pioneiro das pesquisas sobre o tema. Embora nascido na Alemanha, foi professor na Universidade de Estocolmo, Suécia, e lá desenvolveu seus trabalhos pioneiros.

No início dos anos 1980, Leymann propôs-se a estudar os impactos psicológicos de trabalhadores expostos a comportamentos humilhantes e degradantes no local de trabalho, comportamentos esses que se estendiam no tempo. Buscava atingir, com isso, todos os atores envolvidos nos processo de trabalho, principalmente os assalariados e suas entidades sindicais, mas também administradores, economistas, psicólogos, juristas, médicos etc.

Leymann foi o responsável por cunhar as expressões psicoterror e mobbing para as situações pesquisadas, onde uma pessoa tornava-se alvo de outra ou de um grupo na empresa onde trabalhava e era continuamente agredido, perseguido pelos agressores. Como eram análises iniciais, seria preciso uma definição para que fosse possível a sua divulgação e identificação por parte das vítimas.

O termo mobbing designa uma atitude de grupos de animais contra um indivíduo tido como perigoso, como um predador. O grupo orquestra-se para atacar o seu alvo 
coletivamente, afastando o mal potencial. A analogia com situações nas organizações de trabalho foi um primeiro passo para identificar o mal.

Através de seus estudos, divulgaram-se números que expressavam o assédio moral em termos de quantidade. Nos cálculos iniciais em relação aos trabalhadores suecos, estimou-se que 3,5\% dos 4,4 milhões de assalariados haviam sofrido algum tipo de perseguição moral por mais de quinze meses no local de trabalho (BARRETO, 2006, p. 27).

É preciso ressaltar que a Suécia era um país privilegiado para este tipo de estudos. A forte tradição social-democrata escandinava, com um poderoso movimento sindical e um internacionalmente reconhecido quadro de igualdade social muito maior do que em qualquer outra parte do globo o favoreceram.

A partir desses estudos pioneiros, o assédio moral tomou força enquanto mal a ser pesquisado academicamente e combatido sindical e legislativamente por outros países; primeiro europeus, e depois, pra fora do velho continente.

Em meados dos anos 1990, já se reuniam estudiosos do fenômeno na Hungria em um congresso internacional a fim de compilar os conhecimentos já obtidos, dando força à temática. Na Inglaterra, a Fundação Andrea Adams juntamente com o Manufacture Scientific and Financial, então o maior sindicato inglês, entrevistam cerca de mil trabalhadores e constatam que metade já fora vítima de mobbing. Na Itália, surge uma Associação contra o Mobbing e o Stress Psicossocial, a PRIMA, entidade que divulga e combate as práticas de assédio nos locais de trabalho.

Pipocam estatísticas a partir de então. Dados compilados dão conta de que 8,1\% dos trabalhadores europeus foram vítimas de mobbing, sendo 16,3\% dos trabalhadores ingleses, 10,2\%dos suecos, 9,9\% dos franceses, 7,3\% dos alemães. Em 2001, o próprio parlamento europeu afirma que o número de 12 milhões de assalariados europeus vítimas de assédio moral é um dado subestimado (BARRETO, 2006, p. 28). Mesmo considerando esses números como fora da realidade, servem para dar a dimensão do problema.

O debate se fortalece e populariza de uma vez por todas a partir da contribuição francesa. Duas pessoas destacam-se aqui: Christophe Dejours e Marie-France Hyrigoyen.

Dejours tornou-se uma autoridade nos assuntos relativos ao trabalho no mundo. Ainda nos anos 1990, publica um livro analisando o sofrimento no trabalho na França. Não fala em assédio moral, mas associa as novas formas de organização do trabalho, que 
repassam os ônus da competitividade aos empregados, à violência moral cotidianamente relatadas nos ambientes laborais.

Mas foi a obra de Hirigoyen que teve o maior impacto mundo afora. Essa vitimóloga é apontada como autora da expressão assédio moral e difusora mais importante do tema. Seu livro “Assédio Moral no Cotidiano" é tido como responsável por fortes mobilizações de trabalhadores na França denunciando e combatendo os abusos dessa natureza.

Hirigoyen sistematizou pesquisas sobre o assédio moral, dando-lhe uma conceituação até hoje muito utilizada por quem estuda o tema. Mostrou diversos casos em seus livros obtidos por entrevistas ou por pessoas que lhe encaminhavam relatos espontaneamente. Sua definição sobre o assédio moral fundamentou a lei francesa que trata do tema, datada de janeiro de 2002.

O estudo das psicopatologias decorrentes do trabalho ganhou visibilidade e especialização; a psicodinâmica do trabalho evolui tão rápido quanto as transformações na organização do trabalho. Este ramo da psicologia interage com a ergonomia, a medicina do trabalho, a sociologia, a história social, a sociolinguística, a economia do trabalho e com a saúde pública.

Dejours observa que essas interações tiveram dois efeitos imediatos: deslocaram o centro da pesquisa da psiquiatria para a psicologia e solidificaram a denominação "psicodinâmica do trabalho",

corrente mais abrangente por atribuir um lugar tão importante à clínica dos efeitos comprometedores do trabalho sobre a saúde mental (a psicopatologia do trabalho stricto sensu) quanto aos poderosos efeitos do trabalho como potencial mediador na construção da saúde mental (MENDES, MERLO, MORRONE, 2010, p. 141).

$\mathrm{Na}$ Europa e nos Estados Unidos, já há um ramo científico autônomo, a vitimologia, para estudar os processos que tornam um indivíduo vítima e seus impactos nas pessoas.

No Brasil, as pesquisas sobre o assédio moral iniciam-se já no século XXI, despertando o interesse de profissionais de diversas áreas, mormente de juristas e psicólogos. Por pioneirismo, são citados freqüentemente os estudos de Maria Ester de Freitas; por importância, também os de Margarida Barreto. Mas há que se registrar que os 
estudos brasileiros já são considerados como dos maiores e mais importantes do mundo na temática.

\title{
2.2 A Definição de Assédio Moral
}

Percebe-se uma necessidade de estabelecer corretamente uma definição para assédio moral de forma que não haja deturpações do termo e banalização que possam prejudicar o combate a este mal social.

Marie-France Hirigoyen estabeleceu a definição de assédio moral pioneiramente e de forma mais influente nos estudos posteriormente, ao menos no Brasil. Seu livro “Assédio Moral - A Violência Perversa no Cotidiano" trata do assédio em diversas relações sociais; mas foi em relação ao trabalho que gerou as maiores discussões.

\begin{abstract}
Por assédio em um local de trabalho temos que entender toda conduta abusiva manifestando-se sobretudo por comportamentos, palavras, atos, gestos, escritos que possam trazer dano à personalidade, à dignidade ou à integridade física ou psíquica de uma pessoa, pôr em perigo seu emprego ou degradar o ambiente de trabalho (HIRIGOYEN, 2009, p. 65).
\end{abstract}

A vitimóloga atribui ao assédio moral a deterioração do ambiente de trabalho, diminuindo a produtividade e aumentando o absenteísmo. Nasce como algo que não aparenta maiores problemas, mas se propaga, perdura no tempo e torna-se destrutivo.

As vítimas procuram levar na brincadeira ou ignorar em um primeiro momento. Só que as agressões se multiplicam, não param. O indivíduo é acuado, atacado, inferiorizado por um longo e tormentoso período. Surgem os impactos psicológicos mais comuns: humilhação, depressão, cansaço intermitente, perda do sono, crises nervosas, choro.

Como uma bola de neve, os mecanismos de violência vão se acentuando, tornandose cada vez mais violentos. 
tende a anestesiar a vítima, que não irá mostrar senão o que tem de pior (HIRIGOYEN, 2010, p. 67).

O impacto deste livro na sociedade francesa e mundial foi tão grande que a autora publicou anos depois uma nova obra sobre o assunto, agora focada no assédio moral em ambientes laborais. Hirigoyen constatou que a expressão utilizada deu margem à aplicações nem sempre condizentes com sua conceituação clínica.

Em sua obra seguinte "Mal-Estar no Trabalho - Redefinindo o Assédio Moral", procurou-se delimitar com maior precisão a expressão construída por ela, de forma que evitasse o seu uso indevido, o que traria óbvios problemas de divulgação e combate.

Assim, Hirigoyen esclarece a montagem da expressão pelo significado das duas palavras. Assediar define ataques repetidos, insistentes, sem trégua. A importância desta palavra seria caracterizar a agressão enquanto conjunto de ações, algo que se propaga no tempo, o que o tornaria mais degradante por ser uma agressão conglobada, em detrimento de ataques pontuais.

A palavra moral também teria um significado preciso. $\mathrm{O}$ tipo de agressões tratadas aqui trariam considerações sobre o bem o mal, do que seria aceitável ou não na sociedade. Trazer o debate para a moral ou a ética era importante porque as vítimas sentem-se rejeitadas, maltratadas; a moral qualificaria o sentimento de injustiça das vítimas, colocando-as no centro da conceituação do assédio.

Nada mais justo, uma vez que são as vítimas que sentem os impactos do assédio, que sofrem com suas conseqüências. Do agressor, só interessaria a intencionalidade de seus atos, com vistas à sua punição. Vitimologia.

Ao explicar melhor o termo, Hirigoyen aperfeiçoa o conceito de assédio moral, propondo uma definição que superasse à do livro anterior, enriquecida com os debates que se sucederam.

O assédio moral no trabalho é definido como qualquer conduta abusiva (gesto, palavra, comportamento, atitude...) que atente, por sua repetição ou sistematização, contra a dignidade ou integridade psíquica ou física de uma pessoa, ameaçando seu emprego ou degradando o clima de trabalho (HIRIGOYEN, 2010, p. 17). 
Percebe-se aqui presentes diversos elementos caracterizadores do assédio moral, como a ação, a sistematicidade, o estabelecimento de um alvo, a intencionalidade do agressor e a degradação da vítima e do ambiente de trabalho.

A ação, como visto acima, pode ser qualquer conduta abusiva, de forma que é impossível estabelecer quais ações poderiam ser interpretadas como assédio moral; este se manifesta de várias maneiras. Pode se dar na forma de reclamações aos gritos contra um empregado mesmo que este não esteja fazendo nada de errado, gestos desabonadores, palavras ofensivas, um isolamento contínuo da vítima, a sua exclusão das tarefas etc.

O caráter sistemático das agressões é sempre ressaltado, pois o assédio moral visa destruir a vítima, aniquilá-la física ou psiquicamente. Um ato violento isolado não constitui assédio, pois este deve ser prolongado no tempo. Por isso, é possível falar também em processualidade, pois a repetição dos ataques dão a idéia de uma violência processual que causa danos muito mais graves do que ataques individuais; ao contrário, o assédio é sempre repetitivo, sem trégua.

Via de regra, os estudiosos consideram ser necessário a individuação do alvo, mas ressalvam que não é impossível que o alvo seja mais de uma pessoa. Melhor fazem aqueles que consideram o alvo a pessoa ou as pessoas agredidas, porque o assédio moral pode se dar contra vários, contra um grupo. É plenamente possível que um grupo seja inteiramente perseguido por um chefe mais grosseiro ou uma empresa que submeta seus empregados todos a métodos violentos de gestão. Uma fazenda que mantenha empregados em situação análoga à de escravo, por exemplo, deve ser condenada por assédio moral coletivo.

Frise-se nesse aspecto que a relação de poder violenta não tem a ver com a hierarquia, sendo plenamente possível a ocorrência de assédio moral ascendente (de um inferior hierárquico contra um superior) ou horizontal (entre duas pessoas de igual hierarquia).

A intencionalidade do agressor é comumente afirmada com a ressalva de que é possível que o assédio se inicie sem este requisito, mas a sua persistência inclua a intenção do agente depois. Ocorre que a vitimologia é assentada, como o próprio nome diz, sobre a vítima e os efeitos sentidos por esta em virtude do assédio; a psicodinâmica do trabalho estuda a saúde mental em ambiente laboral, ou seja, com a pessoa agredida; para o Direito do Trabalho, não interessa se houve intenção ou não do agente, ensejando o fato a reparação por dano. 
Assim sendo, é de se questionar a intenção do agente agressor, sendo melhor preocupar-se com o dano causado à vítima, quando tratar-se de assédio moral. Por isso, a degradação da vítima e do ambiente de trabalho enquanto característica do assédio moral.

Um ambiente de trabalho onde ocorra assédio moral é um ambiente degradado, violento, nefasto para o exercício de qualquer atividade profissional. Mesmo para quem não é alvo do assédio, a violência exerce opressão porque, se fazem com o outro, podem fazer com qualquer um. Violência em local de trabalho sempre desemboca em mais violência.

A vítima de assédio moral é atacada psicologicamente, sendo a sua dignidade e personalidade aviltada. Porém, não é só a sua saúde mental a atingida, podendo desencadear reações que afetem também a saúde física. Não é incomum, por exemplo, que uma vítima assediada tenha dificuldade de dormir, perca peso e fique com o organismo debilitado, suscetível a qualquer doença.

As características aqui elencadas não esgotam o tema e são passíveis de controvérsia. Contudo, tem a importante função de melhor desenhar o conceito, tornando-o mais perceptível por quem o estude. Ademais, encontram-se quase todos ressaltados por diversos especialistas na temática. A simples transcrição de alguns estudiosos assim o demonstra.

\footnotetext{
O conceito de assédio moral, que podemos compreender como um processo sistemático de hostilização, direcionado a um indivíduo, ou a um grupo, que dificilmente consegue se defender dessa situação. Esse processo pode ter por efeito, ou resultado, algum tipo de prejuízo para o agredido, que pode ser simplesmente a criação de um ambiente hostil, que traga desconforto físico e emocional, ou até o adoecimento e a exclusão do grupo (GOSDAL, SOBOLL, 2009, p. 17).
}

Na definição acima, percebe-se claramente algumas preocupações das autoras em salientar algumas características do assédio moral. A expressão "processo sistemático de hostilização" trata do fato de o assédio ser um conjunto de agressões que se prolonga no tempo, uma agressão processual, diversamente de um ataque pontual. Utilizou-se tanto a idéia de processo quanto de sistema para reforçar tal entendimento.

Percebe-se também uma preocupação de negar o entendimento manifestado por alguns autores de que o assédio moral só pode se dar contra um indivíduo. O assédio moral 
pode, sim, ocorrer contra mais de uma pessoa, como acontece quando tratar-se de assédio moral organizacional, a ser estudado mais à frente.

Depreende-se da definição acima que o resultado não precisa ser necessariamente um dano pessoal ao indivíduo, podendo ser meramente a criação de um ambiente laboral hostil, violento. Tal perturbação, mesmo que não trouxesse um dano físico ou emocional à(s) vítima(s), por si só já configura o assédio para as autoras, embora o mais comum seja “o adoecimento e a exclusão do grupo".

Em outra importante obra escrita coletivamente, tem-se a seguinte definição.

O assédio moral é uma conduta abusiva, intencional, freqüente e repetida, que ocorre no ambiente de trabalho e que visa diminuir, humilhar, vexar, constranger, desqualificar e demolir psiquicamente um indivíduo ou um grupo, degradando as suas condições de trabalho, atingindo a sua dignidade e colocando em risco a sua integridade pessoal e profissional (FREITAS, HELOANI, BARRETO, 2009, p. 37).

Uma diferença importante surge em relação à definição anterior: a intencionalidade, em acordo com a definição de Hirigoyen. A transcrição acima coloca claramente a intencionalidade como condição do assédio moral. E mais: haveria uma intenção perceptível de atingir os resultados, que seria diminuir, humilhar, vexar, constranger, desqualificar e demolir psiquicamente a(s) vítima(s).

Marcia Novaes Guedes propõe o seguinte delineamento.

No mundo do trabalho, assédio moral significa todos aqueles atos comissivos ou omissivos, atitudes, gestos e comportamentos do patrão, da direção da empresa, de gerente, chefe, superior hierárquico ou dos colegas, que traduzem uma atitude de contínua e ostensiva perseguição que possa acarretar danos relevantes às condições físicas, psíquicas, morais e existenciais da vítima (GUEDES, 2008, p. 33).

O caráter processual e sistemático do assédio adquire, aqui, a idéia de continuidade e ostensividade. A autora incorporou ao conceito as classificações de assédio descendente (gerente, chefe, superior hierárquico), horizontal, (colegas), ascendente (subordinados) e organizacional (direção da empresa). Esclareceu que os atos podem ser omissivos ou comissivos - ocultações de informações relevantes os primeiros, reclamações constantes 
em público os segundos por exemplo. Também acatou-se a idéia de que o mal não precisa necessariamente ter ocorrido para que o assédio tenha se consumado ("que possa acarretar").

O conceito está em aberto, em definição. Sua evolução dá-se com a própria evolução das relações de trabalho, que trazem situações novas, incrementando o assédio e o requalificando. Isso é mais fácil de perceber ao ler a definição de mobbing proposta por Leymann.

\begin{abstract}
Uma interação social através da qual um indivíduo (raramente mais) é atacado por um ou mais indivíduos (raramente mais de quatro), diariamente e por muitos meses, levando-o a uma posição quase indefesa e de alto risco de demissão (a pessoa é levada a pedir demissão ou acaba demitida) (apud GOSDAL, SOBOLL, 2009, p. 24).
\end{abstract}

Por esta definição, percebe-se porque o termo mobbing foi adotado por Leymann: a situação descrita é claramente análoga ao mobbing original. Essa expressão advém das ciências da natureza e descrevem uma situação normalmente anti-predatória, onde um grupo de animais se une para atacar e expulsar um animal maior.

Por ter sido o pioneiro, Leymann não se valeu das ricas análises de dados que o sucederam, com descrição de casos os mais variados, o que requalificou deveras o assédio moral; nem mesmo essa expressão havia em seu tempo.

Preocupou-se em prescrever o caráter processual dos ataques de modo que o definiu com diários e por durante muitos meses; sabe-se atualmente que a quantidade de vezes que ocorre varia tanto de caso a caso que é melhor não estabelecer uma temporalidade. Ignorou a possibilidade de um assédio moral organizacional.

Porém, Leymann utilizou expressões que relativizaram o conceito, facilitando a sua superação pelos que vieram. Ele fala de uma vítima, mas deixa a possibilidade de ser mais de uma; numera os agressores ("raramente mais de quatro"), mas não veta um número maior.

Leymann chegou a elencar quarenta e cinco ações e estabelecer que o mobbing acontece quando uma ou mais daquelas ações se repitam ao menos uma vez por semana e por seis meses no mínimo (HIRIGOYEN, 2010, p. 30). Por óbvio, essa definição não é mais aceita hoje, a despeito de sua inegável importância. 
Como o conceito é relativamente novo e aberto, afeito a relativizações e superações, a própria Hirigoyen, provavelmente a maior responsável pela divulgação do assédio moral, está sujeita a críticas. Na preocupação de diferençar o que é do que não é assédio, para evitar a banalização do termo, a vitimóloga francesa marcou diferenças rígidas e discutíveis.

Agressões pontuais, de fato, não são consideradas assédio moral pelo próprio significado do termo: assédio, como já falado, pressupõe ataques sucessivos, duradouros, sem trégua. Nem mesmo em situações extremas de humilhações, como um empregado que depara-se com a porta de sua sala com a fechadura alterada para que não entre, é aceito como assédio por ela.

Juridicamente falando, pode haver um dano moral em um gesto único passível de reparação como se verá adiante. Mas não será considerado assédio, a despeito da violência.

Conflitos profissionais também não são considerados assédio moral. Entende-se que a existência de conflitos seja até positiva para uma organização na medida em que choca pontos de vista diferentes sobre a mesma questão. As divergências são, inclusive, a base da democracia, fundamentando a existência de diversas instituições, como o parlamento e o devido processo legal.

Entretanto, o conflito supõe a possibilidade de aceitação das divergências, de modo que uma parte não possa sufocar a outra, ainda que não a aceite.

O que caracteriza então um conflito é a "escalada simétrica", ou seja, uma igualdade teórica entre os protagonistas. Aceitando o conflito, reconhece-se a existência do outro como interlocutor e o pertencimento a um mesmo sistema de referência (HIRIGOYEN, 2010, p. 25).

Nesse caso, fala-se até em um “conflito consensual”, uma vez que a ambos os lados do contencioso é permitida a expressão, sem humilhações e constrangimentos. Também aqui não se fala em assédio moral, por mais duro que seja o embate.

Outras formas de violência são citadas por Hirigoyen como diversas do assédio moral de forma mais breve. A violência externa, na forma de uma agressão de um criminoso ou de um cliente por exemplo. Porém, é dever da empresa tomas as medidas cabíveis para que cessem as agressões, mormente quando se repetem e se assemelham ao assédio. 
A violência física é outro tipo de violência que não considerado assédio moral. Pode ser que uma situação de assédio resulte em uma agressão física; pode ser também que a vítima tenha alguma degradação física decorrente da degradação psíquica. Mas tal forma de ataque também não se enquadra nas definições de assédio propostas.

O assédio sexual igualmente é um instituto diverso, à parte. Isso se justifica porque em, muitos países, já há previsão legal de tipificação penal para esta sorte de violência, que afeta principalmente as mulheres, de idade menos avançada e situação sócio-econômica mais humilde.

Porém, três formas de violência apontadas por Hirigoyen como não enquadradas na definição de assédio moral merecem reparos: o estresse, a gestão por injúria e as más condições de trabalho.

Referindo-se ao estresse pelo seu significado popular de más condições e sobrecarga do trabalho, diferencia o estresse do assédio, mesmo que este tenha aquele enquanto uma primeira fase. De fundamental, haveria a percepção ou não da vítima de ser o alvo da agressão.

\begin{abstract}
Se uma pessoa está sobrecarregada, incumbida de tarefas sem lhe terem dado os meios de executá-las, precisa de um certo tempo para julgar se é ou não um tratamento exclusivamente destinado a ela. As consequiências dessa agressão sobre sua saúde serão pouco diferentes das de uma sobrecarga do trabalho ou uma má organização, pois, mesmo que seu corpo reaja fortemente, ela não terá consciência do que lhe sucede (HIRIGOYEN, 2010, p. 20).
\end{abstract}

A partir dessa significação do estresse, define o assédio moral a partir do momento em que a vítima percebe que é objeto de uma agressão mal intencionada, quando os gestos violentos tornam-se, aos seus olhos, intencionalmente injuriosas e humilhantes. Segundo ela, o impacto moral na vítima é muito maior quando esta se dá conta de estar sendo deliberadamente atacada.

$\mathrm{O}$ agravante seria o fato de a vítima não entender o porquê daqueles ataques dirigidos a ela, não saber que motivos teria dado para as agressões se sempre se esforçou para dar o melhor de si no trabalho. "Trata-se de uma ferida no amor-próprio, um atentado contra a dignidade, mas também uma brutal desilusão ligada à perda súbita de confiança que se tinha depositado na empresa, na hierarquia ou nos colegas" (HIRIGOYEN, 2010, p. 20). 
Hirigoyen chega a utilizar o exemplo de um empregado de um banco em processo de reestruturação como exemplo. As reformas e as demissões degradaram as condições de trabalho: ambos aumentaram a carga aos empregados que restaram, o que tornou o trabalho deveras estressante. Os funcionários mais antigos foram particularmente atingidos porque submetidos a mudanças para pior e chefes mais jovens.

Um desses funcionários antigos está bastante estressado. Por um motivo qualquer fora do ambiente laboral, sofre um acidente e recebe um afastamento previdenciário. Como o momento é de aumento geral da carga de trabalho, ele passa a ser discriminado por sua chefa, que não gostou do seu afastamento. É constantemente vigiado, seu trabalho recebe críticas todo o tempo, sua mesa muda de lugar para que sua superiora o observe de perto.

Para Hirigoyen, somente no segundo momento é que se pode falar em assédio moral porque, inicialmente, seria apenas estresse, aumento da carga de trabalho; só depois é que a situação se agravaria, passando a ser agressões sistemáticas visando humilhar a vítima, constrangê-la intencionalmente até sua saída da empresa.

Acontece que o estresse é a resposta de um corpo a exposição intensiva de fatores externos agressivos. Será abordado mais detalhadamente à frente, quando tratar-se-á dos efeitos do assédio moral nos indivíduos.

Aqui, interessa ressaltar que fatores estressantes no ambiente de trabalho favorecem a ocorrência de assédio moral, porque aumentam o grau de violência e as respostas às diversas situações cotidianas ficam normalmente mais agressivas. Por outro lado, ataques sistemáticos como os caracterizadores do assédio moral podem desencadear estresse nas vítimas como resposta às agressões.

Estresse e assédio moral, embora não sejam a mesma coisa, mantém entre si uma relação muito mais íntima do que o sugerido por Hirigoyen.

O assédio moral se refere ao contexto de trabalho, o estresse ocupacional se refere às alterações na saúde das pessoas, em decorrência dos esforços de adaptação das demandas impostas neste contexto (GOSDAL, SOBOLL, 2009, p. 47).

Outro ponto discutível trata-se da chamada gestão por injúria. Entende-se essa como um conjunto de comportamentos tirânicos de um gestor que expõe todos os seus 
subordinados a mecanismos intensos de pressão constante com total desrespeito generalizado, onde sobram injúrias e violência.

Algumas diferenciações são feitas destes casos com o assédio moral por Hirigoyen. Primeiro, o assédio moral seria normalmente velado, sub-reptício, enquanto a gestão por injúria seria aberta, visível a todos. Segundo, que esse tipo de gestão traria agressões generalizadas, sem distinção de vítimas, atingindo a tudo e a todos.

Hirigoyen se apega aqui à necessidade de individualização da vítima. Mesmo que se admita a possibilidade de assédio a mais de uma pessoa, essa(s) estaria(m) bem definida(s) enquanto alvo(s). Essa diferenciação acaba por aproximar o conceito de assédio moral do conceito de mobbing proposto por Leymann e, a despeito de inegável importância, já superado com o surgimento de elemento e estudos novos.

Além disso, não é plausível a idéia de que o assédio tenha que ser, necessariamente, velado, uma vez que essa possibilidade não é aventada em vários dos casos trazidos, por Hirigoyen inclusive.

As más condições de trabalho também são apresentadas pela vitimóloga como diversas de um assédio moral. Novamente, a falta de individuação da vítima é levantada como justificativa para estabelecer a diferença, uma vez que é afirmado que tais más condições só configurariam assédio moral se destinadas a um funcionário específico.

A intencionalidade é trazida aqui à condição de diferenciação: se houver uma degradação deliberada das condições de trabalho contra um funcionário, configura-se assédio; se, por outro lado, a degradação for motivada apenas por desleixo da empresa, não o configura, sendo levado à alçada de fiscais do trabalho ou dos sindicatos.

A despeito dos méritos dos argumentos acima levantados e da existência de estudiosos do tema que defendam as diferenciações do assédio moral em relação ao estresse, à gestão por injúria e às más condições de trabalho, é notável que há divergências quanto a esses pontos.

Tais diferenciações se apegam ferrenhamente a elementos secundários para a caracterização do assédio, dogmatizando o conceito, tornando rígido algo que, por ser cientificamente novo, deve ser flexível e estar aberto à superações constantes.

Negar as notórias relações do estresse com o assédio e diferenciá-lo da gestão por injúria e das más condições de trabalho significa negar a existência de algo que é cada vez mais sério e mais grave e merece mais atenção do que os casos já consolidados pelos especialistas: o assédio moral organizacional. 


\subsection{O Assédio Moral Organizacional}

Ao tecer comentários sobre possíveis causas da ocorrência de assédio moral, Hirigoyen afirma que se deve abordar o problema por dois prismas: o psicológico, que leva em conta o histórico pessoal dos envolvidos (vítima e agressor), e o organizacional, que leva em conta a gestão.

Não seria possível analisar o assédio somente a partir das fraquezas da vítima ou de sua incapacidade de se defender; também não poderia se observar apenas uma necessidade intrínseca de humilhar as pessoas à sua volta para se afirmar por parte do agressor. Mesmo sob o prisma psicológico, há variações a serem estudadas.

Porém, Hirigoyen considera que sopesar os aspectos psicológicos e organizacionais não quer dizer que estes últimos prevaleçam sobre aqueles. Isso é, não se poderia afirmar que a culpa é do capitalismo selvagem ou da globalização neoliberal, que impõe novos mecanismos de gestão que favorecem condições de assédio. Compreender o lado organizacional não poderia desresponsabilizar os indivíduos por suas ações.

A vitimologia deveria se preocupar com essas ações individuais que são a causa direta do assédio. Não se poderia deixar de atribuir um protagonismo à vítima e ao agressor, este para que seja punido por seus atos. Mesmo reconhecendo que a forma como as empresas se organizam pode favorecer ou, até mesmo, incentivar a violência no ambiente de trabalho e o assédio moral, como também o grau de tolerância da sociedade circundante e dos grupos sociais envolvidos. "Todos esses determinismos estão interligados, mas o indivíduo continua tendo, apesar de tudo, liberdade de ação ou reação" (HIRIGOYEN, 2010, p. 186).

Essa ênfase dada às ações individuais pode ser oriunda da cultura liberal européia em geral e francesa em particular. Pode ser uma decorrência lógica de um ramo da ciência, a vitimologia, que se preocupa em compreender os impactos da violência nas pessoas individualmente consideradas. Pode ser ainda uma preocupação em repreender, punir os agressores de modo a combater o mal.

Porém, é certo que o "psicologismo em excesso", que ela mesma critica, pode engessar a idéia que se tem de assédio moral. Pior: pode significar a desconsideração do 
problema onde ele é mais grave, porque não mostra o rosto. Apegar-se à individuação do agressor pode não ser o caminho mais eficiente para combater o assédio moral.

Após tecer essas considerações, a autora afirma que, se as práticas de assédio tem se intensificado nos últimos tempos, a explicação será nos contextos profissionais violentos, de mecanismos de gestão perversos ou turbulentos, que serviriam como uma espécie de autorização organizacional para as agressões individuais.

Como exemplo de como a nova organização do trabalho favorece a violência, ela volta ao tema do estresse. É reafirmado que estresse e assédio moral não são a mesma coisa, mas um permite ao outro prosperar com mais facilidade. Mas a exigência de maior produtividade, a intensificação da carga de trabalho, a redução do tempo e o aumento das tarefas anestesia os empregados e dão a entender que não existem regras, só metas.

Nesse contexto, difunde-se a idéia de que tudo é permitido para se chegar aos objetivos da empresa, e os chefes são estimulados a cometer abusos, perseguições, cobranças violentas que redundem em assédio moral. A tensão permanente impede inclusive de os trabalhadores se importarem com o outro; ao invés de defender o colega das agressões dos gestores, é melhor se preocupar em cumprir suas tarefas para que não seja o próximo perseguido.

Outro problema das organizações que favorece a ocorrência de assédio seria a má comunicação. A falta de diálogo, de espaços de fala democráticos, a linguagem seca, direta, os informes descendentes que não permitem questionamentos, tudo leva à insegurança dos subordinados. Estes temem pedir esclarecimentos para não parecerem incapazes, não se sentem à vontade para questionamentos, não conseguem dar sugestões inovadoras. A falta de uma estrutura comunicacional adequada impede que um empregado defenda-se ou peça ajuda se agredido.

A padronização das tarefas também é exemplificada. As empresas divulgam que perseguem profissionais inovadores, mas sempre os enquadram ao seu perfil, tolhem a criatividade. De forma absolutamente conservadora, preferem "indivíduos formatados", que se conformem com o modelo padronizado.

Como esse modelo é imposto de cima pra baixo, os chefes da hierarquia enquadram seus subalternos de forma tirânica, achando que fazem o bem para a empresa ao uniformizar as condutas. Os trabalhadores não conseguem fugir da armadilha pelo temor da rejeição; submetem-se às ordenações superiores e, quando se dão conta da violência a 
que estão submetidos, já é tarde demais: seu psicológico já está abalado e a reação é mais difícil.

A necessidade e a falta de reconhecimento é outro fator organizacional a ser considerado por Hirigoyen. Contudo, ela mantém-se irredutível à necessidade de individuação dos agressores e das vítimas para que se possa corrigir as seqüelas destas e punir aquelas. As questões relacionadas à gestão favorecem a ocorrência, mas não são hipóteses de assédio moral. Todavia, os estudos que se seguiram apontam para outra direção.

Identifica-se uma objetivação do assédio moral, contra a subjetivação pura e simples. Os novos mecanismos de gestão começam a ser responsabilizados pela violência, em detrimento da culpabilidade exclusiva dos indivíduos agressores. Percebe-se que a nova organização do trabalho trazida pelo capitalismo concorrencial global

quebra as relações e os contratos de trabalho, legitima a competição acirrada em todos os níveis, individualiza as culpas e os prejuízos pelo não atendimento de metas descabidas, torna facilmente a empresa em uma pessoa jurídica nômade sem responsabilidades locais, eleva o ritmo e a flexibilidade do trabalho, coloca a guerra econômica como o álibi para justificar a sobrevivência da empresa a qualquer custo e gera um ambiente de trabalho em que a violência começa a fazer morada permanente (FREITAS, HELOANI, BARRETO, 2009, p.35).

O clima frenético de guerra de todos contra todos, não apenas permite, como engendra a violência. Menos do que uma omissão que favorece o assedio moral, o problema organizacional é um problema comissivo; a gestão, em si, é o agente agressor.

A generalização da violência nas organizações acarreta mais violência. Sua banalização faz com que as pessoas acatem como normal algo que, necessariamente, deveria ser excepcional. As agressões passam a fazer parte de um cotidiano perverso. Basta lembrar como nos governos do PSDB falava-se em flexibilização do Direito do Trabalho com uma naturalidade estarrecedora, quando a simples idéia de flexibilizar as condições de vida de quem vive do trabalho deveria chocar.

Um ambiente de trabalho selvagem e concorrencial, de competição entre as pessoas que deveriam estar unidas lutando por seus direitos comuns, é agressivo por natureza. Seu resultado é uma agressão generalizada à saúde física e psíquica dos empregados. 
Entendemos que analisar a violência, pelo seu desdobramento de assédio moral, como um problema das organizações, pode abrir espaço para o resgate de um ambiente mais colaborativo, mais honesto e mais saudável para as pessoas e para os negócios (FREITAS, HELOANI, BARRETO, 2009, p. 37).

Maria Ester de Freitas, Antonio Heloani e Margarida Barreto afirmam categoricamente que, sendo as organizações o palco onde o assédio moral acontece, sua estruturação é determinante para a violência, podendo incentivar, reduzir ou extinguir o mal. São as empresas que ditam as relações internas entre seus empregados.

Nas organizações, os atores e atrizes pautam suas condutas pelo aspecto legal mais do que o aspecto moral. Porém, inegavelmente, a moral tem um peso considerável, levando-se em conta que nem todas as ações são tuteladas pelo Direito. Cada ação de cada indivíduo é precedida pela avaliação se o que se fará é certo ou errado, devido ou inadequado. As normas estabelecidas pelos regulamentos internos são as mais importantes; mas a construção de uma consciência coletiva sobre o agir, talvez, seja utilizada com mais freqüência.

Freitas, Heloani e Barreto sugerem, então, que a cultura interna de uma empresa condiciona as relações intersubjetivas e intergrupais, o grau de intimidade permitido, as formas de comunicação, os mecanismos de superação de atritos. Enfim, condicionam o ambiente de trabalho.

\footnotetext{
Quando consideramos o assédio moral uma questão organizacional, entendemos que algumas empresas negligenciem os aspectos desencadeadores desse fenômeno, ou seja, consideramos que o assédio moral ocorra não porque os dirigentes o desejem, mas porque se omitem (FREITAS, HELOANI, BARRETO, 2009, p. 38).
}

Tal interpretação distingue-se da ofertada por Hirigoyen, que pressupunha um indivíduo intencionalmente agressor. Agora, entende-se que a própria empresa é a agressora, por utilizar mecanismos de gestão violentos. Seus dirigentes estimulam a violência interna e não intervém para interromper os ataques. Os agressores encontram respaldo na própria organização, que tem na violência uma regra, uma cultura, uma filosofia de funcionamento. 
Nesse ambiente agressivo e permissivo, surgem abusos e humilhações generalizados. Diversos são os exemplos apresentados: empregados que cometem erros são expostos à humilhação coletiva, são estabelecidos rituais ofensivos contra aqueles que não atingem suas metas, trabalhadores reintegrados após afastamento previdenciário são deliberadamente discriminados.

O modo de funcionamento das organizações ocasiona o assédio moral. A ultraespecialização cria uma valorização desenfreada da hierarquia onde os chefes, de tão poderosos, facilmente, abusam de seu poder. Como encontram aceitação de suas práticas despóticas pela empresa, a cultura estabelecida é de violência generalizada, destruindo a integridade dos empregados indistintamente.

Os mega processos de fusão ou aquisição de empresas umas pelas outras força uma reestruturação repleta de atritos. Como o procedimento nunca é democrático, acirram-se os atritos interpessoais, frustrações com a não ascensão a um cargo desejado, inveja pela ascensão de um colega considerado inferior, disputas sem a menor preocupação com a ética.

As terceirizações, via de regra ilegais, dividem os trabalhadores entre os integrados pela empresa principal, bem remunerados, instruídos e com maior poder de decisão, e aqueles de "segunda classe", contratados pelas terceirizadas a baixos salários, sem proteção e segurança adequada, que só recebem ordens de formas as mais humilhantes possíveis.

O assédio moral torna-se uma questão intrínseca ao funcionamento da empresa. É o assédio moral organizacional.

Essa modalidade de assédio é atribuída à hierarquia inerente às empresas capitalistas. A gestão da mão-de-obra coordenada por um centro administrativo visando extrair o máximo de produtividade do trabalho, fundamento de poder diretivo positivado juridicamente, é um prato cheio para o cometimento de abusos. Em nome do aumento dos lucros, as organizações estabelecem condições de trabalho naturalmente agressivas, ofendendo a saúde física e psíquica dos empregados e atentando contra a dignidade destes.

Atribui-se a Adriane Reis o primeiro trabalho acadêmico brasileiro que se propõe a conceituar o assédio moral organizacional. Em uma pesquisa de mestrado, ela trás a seguinte definição: 
O assédio moral organizacional se configura pela prática sistemática, reiterada e freqüente de variadas condutas abusivas, sutis ou explícitas contra uma ou mais vítimas, dentro do ambiente de trabalho, que, por meio do constrangimento e humilhação, visa controlar a subjetividade dos trabalhadores (apud GOSDAL, SOBOLL, 2009, p. 34).

Reis frisa que esse controle da subjetividade pode se apresentar enquanto uma licitude, como a adesão às regras da empresa, o estabelecimento de metas, o controle do tempo de ida ao banheiro, ou enquanto uma medida explicitamente ilícita, como a apreensão da carteira de trabalho.

Essa definição tem o mérito de ampliar a interpretação do que seja assédio moral. Utiliza-se de importantes elementos caracterizadores do assédio, como a sistematicidade e a degradação psíquica da vítima. Porém, inova radicalmente ao apontar como o agressor não uma pessoa sádica em particular, mas a empresa. Esta se utiliza de seu poder de direção para controlar e disciplinar seus empregados de forma a atentar contra a dignidade humana.

Thereza Cristina Gosdal, Lis Andrea Soboll, Mariana Schatzmam e André Davi Eberle saúdam a iniciativa, mas criticam a definição acima por considerá-la demasiado ampla. Entendem que, da forma como o problema é colocado na dissertação de Reis, todo assédio que não fosse causado meramente por questões interpessoais seria organizacional, o que traria problemas porque descuidaria da intenção e da responsabilidade da empresa. É possível ir além dessa crítica e constatar que a definição acima centra-se apenas na mobilização subjetiva do trabalhador quando, na verdade, esse controle subjetivo não é um fim em si mesmo, é um meio utilizado para aumentar a produtividade empresarial.

Essas autoras afirmam que, para caracterizar o assédio moral organizacional, é importante frisar o seu caráter de política empresarial, modelo de gestão da empresa. Para fazê-lo, sugerem diferençar o assédio moral em duas modalidades: o interpessoal e o organizacional. O primeiro seria o conceito consagrado em todos os ramos da ciência que o estudam; o segundo estaria focado na violência como mecanismo de controle, política de gestão do empregador. Daí, organizam sua definição.

O assédio organizacional é um conjunto sistemático de práticas reiteradas, inseridas nas estratégias e métodos de gestão, por meio de pressões, humilhações e constrangimentos, para que sejam alcançados determinados objetivos empresariais ou institucionais, relativos ao controle do trabalhador (aqui incluído o corpo, o comportamento e o tempo de trabalho), ou ao custo do trabalho, ou ao 
aumento de produtividade e resultados, ou exclusão ou prejuízo de indivíduos ou grupos com fundamentos discriminatórios (GOSDAL, SOBOLL, 2009, p. 37).

Percebe-se claramente que as definições de assédio moral organizacional buscam superar as definições de assédio moral interpessoal, que é o clássico, o tradicional, iniciado com a analogia ao mobbing. Mantém-se o núcleo do conteúdo do assédio, o que engloba a reiteração dos ataques ao longo do tempo e a destruição psíquica e física da vítima e das condições de trabalho.

O salto de qualidade que se dá é considerar o assédio moral enquanto política de gestão de mão-de-obra. Há uma preocupação em compreender a violência objetivamente, enquanto um mecanismo de aprisionamento dos empregados para potencializar os lucros da empresa às custas da saúde de seus trabalhadores. Em vez de condenar um chefe autoritário, puna-se a empresa, beneficiária que é da hiper-exploração.

A intencionalidade, conforme já antecipado, é relativizada. Para as autoras, não haveria uma intenção deliberada de atingir o empregado com condições degradantes de trabalho. A intenção, no assédio organizacional, é aumentar a produtividade da empresa, reduzir seus custos, controlar os trabalhadores.

Para diferençar com precisão o assédio moral interpessoal do organizacional, Gosdal, Soboll, Schatzmam e Eberle (2009, p. 39/40) montam uma tabela comparativa entre os dois institutos com suas semelhanças e diferenças.

Ambas as modalidades de assédio se igualam por significarem hostilidades sistemáticas que intimidam e humilham, pela repetição e longa duração das agressões e pela desigualdade de forças entre agressor e agredido.

As diferenças residiriam nos seguintes fatos: o assédio organizacional está inserido nas práticas de gestão e na política da empresa; visa atingir determinados objetivos institucionais (controle dos trabalhadores, aumento da produtividade, cumprimento de metas e resultados e redução de custos); é praticado pelos dirigentes da organização; o alvo é determinável (grupos ou a totalidade dos trabalhadores); estímulo e promoção do assédio pela instituição. De outro lado, o assédio interpessoal visa humilhar e excluir o assediado; pode ser praticado por superiores ou inferiores hierárquicos ou pessoas de mesma hierarquia; o alvo é determinado (normalmente uma pessoa ou um pequeno grupo); e conta com a omissão da empresa. 
A principal diferença entre o conceito inicial de Reis e o dos autores é que aquela trata o assédio organizacional apenas pelo controle subjetivo do trabalhador e estes enfatizam que o assédio organizacional visa os objetivos da empresa, dão um caráter mais amplo à finalidade: o controle subjetivo do trabalhador ou o aumento da produtividade ou a redução dos custos ou a exclusão de um grupo indesejado.

O fundamental desta evolução é caracterizar o assédio moral como parte da estratégia das empresas de controlar seus empregados e aumentar sua produtividade através de práticas violentas de gestão do trabalho. A pressão pelo cumprimento de metas, o constrangimento e a humilhação de quem não atinge os resultados estabelecidos, as agressões a um grupo de empregados da empresa que esta queira dispensar após uma fusão ou uma incorporação, a discriminação de empregados que se afastem temporariamente por motivos legais (previdenciários, cipistas), tudo isso acarreta uma degradação do ambiente de trabalho, destrói a saúde física e mental dos trabalhadores, configurando uma forma de assédio muito pior e mais danosa do que o assédio interpessoal.

Este trabalho, a par da conceituação do assédio moral organizacional, focar-se-á nessa modalidade de violência contra os trabalhadores no que diz respeito às estratégias das empresas para aumentar a produtividade dos obreiros e reduzir custos através do estabelecimento de metas abusivas e da cobrança humilhante pelos resultados. O controle do corpo e da mente dos empregados levado às últimas consequiências será o centro da pesquisa.

Não obstante, o assédio organizacional que visa excluir um grupo será abordado lateralmente uma vez que é prática recorrente na economia em geral e nos bancos em particular. Quando de uma fusão ou aquisição de um banco pelo outro, o enxugamento de pessoal é ato continuo. Se o banco adquirido for público, então, a perseguição é maior, como será demonstrado à frente.

\subsection{Os Fundamentos do Assédio Moral Organizacional}

As transformações por que passa a economia em seu processo evolutivo impactam, como não poderia deixar de ser, as relações de trabalho nas organizações. A ciência avança 
no processo de dominação e transformação da natureza pela humanidade. Obstáculos oriundos do tempo e do espaço são superados todo o tempo pelas novas tecnologias.

Mas a ciência não avança apenas no campo natural e exato: avança também no campo humano. A complexidade crescente dos indivíduos e da sociedade traz novos problemas para a psicologia, o direito, a política, a administração, a economia etc. Estas duas últimas evoluem fortemente no sentido de aumentar os lucros e a produtividade do capitalismo, sem medir esforços ou conseqüências.

Para isso, pesam a mão sobre a gestão do trabalho. Jogam nos ombros dos trabalhadores o peso da concorrência, da demanda, da abertura, dos lucros, das metas, dos resultados. O taylorismo, que deslocou dos empregados para os empregadores a administração do trabalho, foi só o começo de uma história de degradação do corpo e da mente da classe que vive do trabalho.

Vincente de Gaulejac (2007, p. 41) aponta três fatores que transformariam profundamente o capitalismo no final do século XX: a financeirização da economia, a mundialização dos mercados e a "ditadura do tempo real" ocasionada pela fusão da informática com as telecomunicações.

As bolsas de valores tornaram-se o centro nervoso da economia. Ao deslocar o centro econômico da produção industrial para a não-produção financeira, as próprias empresas tornaram-se uma mercadoria, cujo valor é avaliado diariamente nas bolsas. Nesse ínterim, tudo vira custos a serem enxugados para se atingir o máximo de atratividade dos investidores.

Antigamente, uma empresa era propriedade de uma família, conheciam-se os "patrões" pessoalmente. Hoje, os fundos de investimento ou de pensão ditam as regras atuando freneticamente no mercado de capitais. Com os avanços tecnológicos, pode-se conhecer a cotação de uma empresa diariamente, se subiu ou se desceu na bolsa; basta ligar o computador ao chegar na empresa e o valor desta está lá, quantificada volatilmente por sua cotação na bolsa e pelas análises financeiras.

Como se mede o lucro mais que diariamente e se visa sempre atrair investidores, todos os efetivos das empresas devem aumentar os lucros e reduzir seus custos. É nesse bojo que a antiga gestão de pessoal deu espaço à gestão de recursos humanos. Ao menos no nome, afirmava-se que havia pessoas nas empresas; agora chama-se pelo que verdadeiramente são: recursos, mesmo que humanos. 
Proliferam-se os managers que atuam nas empresas com vistas a inseri-las nessa ciranda financeira que tornou-se o mundo. Sua função é mobilizar os recursos humanos de forma a potencializar o trabalho coletivo. O significado da expressão dá bem a idéia de seu papel. Segundo Gaulejac (2007, p. 48), management (gerenciamento) vem de manège (equitação), que seria o lugar onde os cavalos são criados e se aprende a montá-los. Ou seja, o uso desta expressão dispensa maiores explicações!

A proliferação dos managers deu-se com a financeirização da economia. A pressão dos acionistas pela redução de custos faz com que a gestão dos recursos humanos endureça o jogo com seus empregados, estabelecendo uma política de salários e outras vantagens trabalhistas e previdenciárias as menores possíveis. Ao mesmo tempo, a globalização econômica desloca empresas pelo mundo à procura de mão-de-obra mais barata; a pressão pela redução dos custos do trabalho dá-se internamente pela gestão das organizações e externamente pela concorrência global que impõe a redução dos custos do trabalho.

O gerencialismo, o mundo dos managers, carrega consigo uma máscara ideológica que oculta suas reais intenções. As ciências gerenciais sempre se apresentam como imparciais, neutras. Seriam técnicas de melhor organizar os recursos das empresas, materiais ou humanos, que garantiriam uma melhor produtividade. Isso é facilmente perceptível quando os "especialistas" aparecem na imprensa para opinar sobre as tendências do mercado, as decisões dos governos, os números do mercado financeiro. São tratados por "especialistas" para fingir que obedecem a uma técnica científica, quando atendem aos interesses dos acionistas na verdade.

\footnotetext{
O paradigma utilitarista transforma a sociedade em máquina de produção e o homem em agente a serviço da produção. A economia se torna finalidade exclusiva da sociedade, participando da transformação do humano em "recurso" (GAULEJAC, 2007, p. 75).
}

O gerencialismo prega que a empresa é o sistema do funcionamento de diversos fatores que interagem; todos têm a sua utilidade, suas funções, suas especialidades e o seu valor. O "fator humano" seria o mais especial, o que demandou a criação de um departamento específico para a gestão dos recursos humanos.

Gaulejac crê que colocar o humano enquanto um fator da empresa leva a uma inversão: a empresa é que pertenceria aos humanos e não o contrário. A empresa deveria 
atender aos objetivos das pessoas e não as pessoas deveriam atender aos objetivos da empresa.

Este trabalho baseia-se na compreensão de que o trabalho é uma mercadoria vendida como outra qualquer, que o capitalismo "coisifica" as pessoas, que não há trabalho digno neste modo de produção. O gerencialismo seria apenas uma especialização da gestão da mão-de-obra nas organizações, um avanço científico para jogar a responsabilidade do sucesso ou fracasso da empresa nos ombros dos seus empregados. Porém, concorda com Gaulejac na análise do gerencialismo e utiliza seus apontamentos para fundamentar a existência de um assédio moral organizacional.

O assédio organizacional foi conceituado anteriormente como a sistemática de práticas de gestão violentas, humilhantes e constrangedoras que visa atingir os objetivos da empresa relativos ao controle do trabalhador, o aumento da produtividade ou a exclusão de um grupo. Por isso, dois elementos analisados por Gaulejac serão salientados: o comprometimento do empregado para os objetivos da empresa (controle do trabalhador) e a quantificação aritmética do desempenho (aumento da produtividade).

\subsubsection{O controle subjetivo do trabalhador - fundamento subjetivo}

A ordem industrial taylorista era extremamente hierarquizada, piramidal. $\mathrm{O}$ rígido controle dos tempos e movimentos e a disciplina visavam a canalizar a atividade física do proletariado para tornar seus corpos úteis, dóceis e produtivos. Já o gerencialismo parte da mobilização psíquica dos empregados, visando a obter o comprometimento destes para os objetivos da empresa.

O poder gerencialista preocupa-se não tanto em controlar os corpos mas em transformar a energia libidinal em força de trabalho. (...) Passa-se do controle minucioso dos corpos para a mobilização psíquica a serviço da empresa. A repressão é substituída pela sedução, a imposição pela adesão, a obediência pelo reconhecimento (GAULEJAC, 2007, p. 109).

Manipula-se livremente o psicológico dos indivíduos para que atuem em acordo aos propósitos das empresas. Invoca-se o desejo pelo sucesso e reconhecimento profissional, o 
crescimento na organização. O trabalho é apresentado como a realização pessoal do indivíduo, realização enriquecedora, desafio estimulante.

A psique dos empregados é mobilizada para tornar-se produtiva e submissa; é sobre ela que incidem as relações de poder e dominação no gerencialismo e não mais sobre a ação física dos corpos como no taylorismo. Mobilizá-la para torná-la força produtiva a serviço da empresa.

A vigilância, então, torna-se menos física do que comunicacional. Ao invés de incidir sobre os movimentos, sobre a atividade dos empregados, ela incide agora sobre os resultados, através do estabelecimento de metas e cobranças. Ao invés de controlar os tempos e movimentos, busca-se o engajamento para os projetos da empresa e o máximo da disponibilidade para o cumprimento das tarefas; ao invés de controlar o durante, controlase o depois.

Os avanços tecnológicos reduzem ainda mais o período de não-trabalho. Se está em um engarrafamento, pode-se agilizar um e-mail ou uma ligação. A mobilização é constante e a pressão pelo atingimento das metas, frenética.

O gerencialismo exige a adesão dos empregados ao seu projeto, oferece a integração total do indivíduo na corporação. A busca pela excelência, o crescimento na empresa pelos méritos individuais, o sucesso contra o fracasso, tudo é canalizado como se o ego do trabalhador estivesse integrado ao grande ego da empresa. "O objetivo do sistema managinário é colocar em sinergia o funcionamento organizacional e o funcionamento psíquico" (GAULEJAC, 2007, p. 122).

Essa lógica traz uma política de "perde-perde" à saúde mental e física dos empregados. Estes experimentam diversas sensações no âmbito laboral, como o sucesso ou a frustração. O problema é que o engajamento psíquico dos indivíduos integra-os na organização; o sucesso desta é o sucesso do empregado.

Para obter o sucesso da empresa que, ao fim e ao cabo é o seu sucesso, o trabalhador envolve todos os esforços possíveis de seu corpo e sua mente, levando-o à exaustão. Por outro lado, se a empresa fracassa, a frustração, a decepção, o sentimento de impotência ou incapacidade é seu, o que também lhe traz prejuízos à saúde.

Há controles mais sutis, implícitos na política do envolvimento narcísico, do "vestir a camisa", através dos programas de auto-estima, afetividade e empatia. (...) $\mathrm{Na}$ prática, isso significa afetividade colonizada na conjugação do eu e do 
nosso, na promessa da satisfação dos desejos individuais submetidos ao "sucesso" empresarial (BARRETO, 2006, p. 101).

Margarida Barreto observa que a própria denominação dos empregados mudou; agora, é "colaborador”, “associado", “cooperador”, "parceiro”, "financiador”. A expressão “empregado" traz consigo uma idéia de subordinação que as organizações tentam suprimir - suprimir a idéia, não a subordinação, frise-se.

Essas novas denominações visam a ocultar as relações de poder e hierarquia reais para motivar os trabalhadores. Estes devem ser mantidos satisfeitos com seu desempenho, motivados para o labor, engajados nos objetivos do capital. Afinal, trabalha-se para o seu crescimento individual, o da "sua" empresa e o da sociedade!

A nova gestão dos recursos humanos busca introjetar nos "colaboradores" os valores relacionados aos novos mecanismos de produção. As mudanças provocadas pelas telecomunicações, pela robótica, pelo toyotismo trouxeram novidades como o kanban e o just in time, que concatenam a produção com a demanda temporal do mercado, os programas de qualidade total que visam obter taxas de defeito o mais próximo possível do zero.

Para obter os resultados exigidos, os trabalhadores devem manter alta concentração nos serviços, serem capazes de se adaptar à equipe, dar respostas rápidas a problemas novos, ter qualificação suficiente para dialogar com os clientes. Não se pode ater-se apenas ao trabalho prescrito; exige-se jogo de cintura para lidar com situações inesperadas. Até porque a bolsa de valores cobra diariamente!

As novas práticas de recursos humanos pregam o enlaçamento do sucesso coletivo ao sucesso individual; se você cresce, a empresa cresce junto. Encarar desafios é uma virtude que o profissional atual deve ter. Ousadia, criatividade, espírito de equipe, empreendedorismo, iniciativa... Em uma palavra: produtividade.

As obrigações do empregado, ao invés de serem ditadas pelos chefes, são interiorizadas por ele; sua subjetividade é assimilada por suas tarefas, fruto da pressão psicológica constante dos novos mecanismos gerenciais. É como se a vítima trouxesse o criminoso para dentro de si de forma deveras masoquista.

Marcus Vinicius Soares Cerqueira aborda esse autoflagelo dos trabalhadores. Aponta que a superação da religião pela ciência trouxe um homem autônomo e consciente, centrado em si. Mas a modernidade trouxe consigo sua própria crítica. 


\begin{abstract}
Marx apresenta as idéias referentes ao descentramento do indivíduo quanto às relações de produção presentes no campo social. Nietzsche indica o quanto as verdades provêm das relações de poder entre os homens, e Freud, com seus estudos do inconsciente, põe limites quanto à auto-determinação do sujeito (In MENDES et alii, 2010, p. 172).
\end{abstract}

Indica que passa-se, então, a buscar em instituições a aceitação para que haja um reconhecimento, uma integração. Essa entrega é total, dócil, submissa. Ausente a figura teológica para guiar as vidas, busca-se outra figura paterna que faças as suas vezes. Tornase uma marionete perante a figura que o absorva e engrandeça.

Uma empresa é o espaço privilegiado para ocorrer esta entrega. Afinal, é no trabalho que se obtém o sustento, o salário. Nela, o indivíduo abdica de sua liberdade em troca do reconhecimento, da possibilidade de ascensão, da aceitação, mesmo sendo ela o seu algoz, que lhe explore até a última gota de suor.

Essa narrativa de entrega teria sido agravada com o advento do neoliberalismo, o desmanche das instituições trabalhistas e previdenciárias de bem-estar social e a possibilidade de exclusão-mor: o desemprego, a exclusão do mercado de trabalho. As novas formas de dominação, quer dizer, de gestão de recursos humanos, evoluem pari passu ao desenvolvimento das forças produtivas e do quadro sócio-econômico.

O controle exercido pelo capital sobre o trabalho não é mais focado nos tempos e movimentos do corpo; ao invés, é exercido sobre a subjetividade dos empregados, que se integram e entregam à empresa. A mobilização subjetiva das emoções dos trabalhadores configura as novas técnicas de gestão.

O assédio moral organizacional constitui, então, a perpetuação dessa estratégia que funciona à base da violência psíquica. Há uma sedução do indivíduo para os objetivos das organizações, uma interiorização destes objetivos, uma pressão constante para o atingimento das metas e resultados cobrados. $\mathrm{O}$ assédio tornou-se estrutural. Mas, para que este exista, a quantificação do trabalho é imprescindível.

2.4.2 A quantificação do trabalho e as avaliações das metas ou o aumento da produtividade - fundamento objetivo 
Um dos piores legados do neoliberalismo foi ter reduzido a economia a uma subdisciplina da matemática. Os economistas preocupam-se tanto com os números a ponto de esquecer que existe uma sociedade formada de pessoas de carne e osso à sua volta. Retiraram o caráter de ciência humana da economia e afirmaram a supremacia do caráter de ciência exata.

Emblemático disso é a quantidade de engenheiros que fizeram pós-graduação em economia a ingressaram no mercado de análises, consultorias econômicas. Um profissional que tem formação altamente vinculada aos números e às equações ingressa em um ramo da ciência que mescla humanidades e exatas. Só pode prevalecer esta última.

O gerencialismo, ideologia que adquiriu grandes proporções justamente no auge do neoliberalismo, levou a objetivação baseada em funções matemáticas às últimas conseqüências: “compreender é modelar, isolando certo número de variáveis e de parâmetros, que podemos então medir" (GAULEJAC, 2007, p. 67).

Propõe-se estabelecer uma espécie de racionalidade ultraformalista que permita enquadrar cada elemento dos recursos humanos em algum tipo de mensuração, de quantificação. O objetivo é estabelecer um padrão racional de condutas em que seja possível manter o comportamento humano o mais previsível, calculável. Se se atinge essa previsibilidade comportamental, fica mais fácil prescrever suas ações para otimizá-las e, o mais importante, calculá-las, "programar sua existência".

Seguindo essa linha, tudo o que é mensurável deve ser rigidamente calculado. O que não for mensurável deve ser descartado porque torna-se inútil aos olhos do gerencialismo: como utilizar algo que não se pode calcular, traduzir em números?

Gaulejac sustenta que a objetividade pode ser louvável, mas querer reduzir a realidade a uma equação impede que se compreenda o comportamento humano e a história das organizações. A “doença da medida” cega os pesquisadores, que não conseguem mais enxergar a condição humana, perdidos que estão no mundo das matemáticas. Mas não é justamente esse o objetivo?

Edward Lazear, economista do trabalho americano focado no estudo do "capital humano", é um exemplo de como a "quantofrenia" avança nas ciências que se ocupam das relações entre capital e trabalho. Estuda qual a melhor forma de contratar um empregado, como remunerá-lo, avaliar o seu desempenho. Calcula como potencializar o rendimento do trabalho a não mais poder. 
Antes de explicar suas teorias e equações, em um extremo de sinceridade, Lazear constata:

\begin{abstract}
Reinforcement of workers through evaluation and raises is not completely dissimilar from psychologists' notion of reinforcement of laboratory animals in a behavioral setting. Pigeons, rats, dogs, and other animals can be induced to behave in particular ways by reinforcing or punishing their behavior (LAZEAR, 1995, p. 103).
\end{abstract}

Para não se cometer uma injustiça contra Lazear, registre-se que ele afirma que os trabalhadores têm duas diferenças importantes com os animais de laboratórios: primeiro, os economistas trabalham com incentivos e avaliações que maximizem o potencial de cada indivíduo, preocupando-se em garantir uma estrutura onde os empregados possam potencializar os lucros da empresa. Segundo, por se tratar de um mercado, o empregado pode sair de uma organização que não satisfaça seus interesses em busca de outra, enquanto os animais de laboratório são escravos dos pesquisadores. Comovente!

A partir dessa constatação nada humanista, Lazear problematiza sobre os mecanismos de avaliação dos trabalhadores. Munido de gráficos, tabelas e equações, compara quando um empregado deve ser avaliado freqüentemente ou pode ser permitido com um intervalo maior entre as avaliações, por exemplo.

A chamada personnel economics preocupa-se com todos os aspectos relacionados aos recursos humanos sob a ótica das organizações e através das ciências econômicas. Percebe-se que as pessoas respondem fortemente a incentivos e, por isso, as empresas devem ter bons mecanismos de estímulos e remuneração para que os indivíduos respondam aos seus objetivos.

Há motivações extrínsecas e intrínsecas dos empregados. As motivações extrínsecas são as que podem partir da empresa, como um incremento na remuneração ou ascensão na hierarquia. Mesmo que haja motivações intrínsecas (interesses pessoais), devese canalizar essas para as metas e resultados pretendidos.

As pesquisas buscam os melhores meios de avaliar o desempenho e remunerá-lo. Se não há motivação intrínseca do empregado, sua atividade terá um custo, uma motivação adicional. O problema é que o trabalho realizado difere do trabalho medido e isso acarreta em mais custo deste esforço medido incorretamente. 
Outra questão trazida por Lazear é sobre a avaliação ser coletiva ou individual. Como nas empresas há vários profissionais interligados com funções complementares, torna-se difícil avaliá-los individualmente. Porém, a avaliação do grupo pode ocultar o fato de um trabalhar mais que o outro. Sempre é salientado que as avaliações visam incentivar os trabalhadores; se mal feita, tem o efeito contrário, desestimula.

A avaliação subjetiva é extremamente custosa e complexa, embora seja considerada por ele a mais adequada. Há o exemplo de uma empresa americana que passa seis semanas realizando avaliações individuais. É longa e custosa, mas é eficiente para os propósitos empresariais.

Diversas questões são apontadas sobre as avaliações. Um profissional mais experiente que passa instruções aos mais novos não tem como ser avaliado por isso. Trabalhadores em postos de comando são mais facilmente avaliados do que um empregado da limpeza. Avaliar pelos lucros obtidos não funciona para todos os empregados funciona para um gerente mas não para um porteiro. Avaliações relativas (comparando os empregados) ou absolutas (pelo desempenho individual) dependem de a empresa querer mais ou menos competição entre eles.

O que importa observar aqui é que a estratégia de avaliação dos empregados visa sempre a motivá-los a cumprir com os objetivos propostos pelas empresas. Nos meios de avaliações, tem-se um poderoso mecanismo de integração do trabalhador à organização através de mecanismos de estímulo e recompensa. Remunerar adequadamente a quem desempenhe seu ofício adequadamente.

Christophe Dejours, porém, profere diversas críticas quanto aos mecanismos atuais de avaliação do trabalho. Afirma que o trabalho não pode ser medido uma vez que representa uma experiência subjetiva incomensurável.

No início, avaliar o trabalho significava avaliar o tempo à disposição do empregado para o trabalho. Só que isso é um erro, pois não mede a intensidade ou a destreza com a qual o serviço é prestado, muito menos a qualidade. Com o incremento tecnológico, principalmente a partir da década de 1970, esse problema tornou-se mais latente e caiu em descrédito.

Dejours parte do princípio de que a maior parte do trabalho é destinada a imprevistos, inesperados, panes, ou seja, situações diversas daquelas formalmente designadas aos empregados. Define, então, o trabalho real como o que o indivíduo 
acrescenta ao que lhe foi prescrito visando a obter os resultados que lhe foram estabelecidos.

Dificuldade adicional é trazida pelo avanço do setor de serviços sobre a participação da indústria na economia. A troca da produção pela prestação, as formas de gestão de mão-de-obra tornam ainda pior a tarefa de avaliar. "Essas tarefas requerem uma mobilização subjetiva por parte do trabalhador em registros invisíveis, uma vez que são relacionais e até mesmo intersubjetivas" (DEJOURS, 2008, p. 62).

Para que o trabalho fosse, de fato, avaliado, deveria trazer à tona uma série de procedimentos desenvolvidos que estão ocultos em relação àquilo que foi prescrito. Assim, com a reestruturação da produção desencadeada na década de 1970, abandonou-se a avaliação pelo tempo de trabalho e passou-se a avaliá-lo pelo desempenho produtivo obtido por cada um com a utilização dos recursos disponíveis. "Mas ao longo de nosso percurso ficou claro que a medida dos desempenhos não é a avaliação do trabalho, pois não há nenhuma proporcionalidade entre desempenho e trabalho" (DEJOURS, 2008, p. 59).

Com o necessário exercício da subjetividade canalizado no setor de serviços, medir o trabalho pelo tempo torna-se descartável. Na sua impossibilidade, tentou-se uma avaliação das competências para aproximar a avaliação do sujeito. A crítica de Dejours é que esta caminha em demasia à pessoa e se afasta do trabalho em si. O desempenho laboral antecede, é um pressuposto para estabelecer a competência e, por isso, seria inviável avaliar mobilização subjetiva existente no setor de serviços, que é uma relação direta entre produtor e usuário.

A bola da vez seria a avaliação da qualidade, a qualidade total. Essa traria a possibilidade de enxergar o trabalho real ao abordar não só o trabalho prescrito, mas o efetivo. Mas as estratégias de marketing, os selos de qualidade ocuparam todo o espaço e a avaliação da qualidade ficou só no nome. A qualidade total acaba por fazer o resultado preceder o trabalho, o que levaria o trabalho prescrito às últimas consequências, por fazê-lo mais rígido e controlado.

Apesar de toda a crítica das chamadas ciências do trabalho, as chamadas ciências da gestão imperam. As avaliações tornaram-se mecanismo de gestão ao manter os empregados sobre pressão de ficarem para trás nos rankings, nas promoções, nos salários diferenciados e porque traduzem o trabalho para o mundo dos números, dos gráficos, das tabelas, que é o mundo pelo qual as organizações sentem-se seguras e previsíveis. Mesmo que diante da falsidade total. 
Exemplos não faltam de que as avaliações, mormente as de qualidade total tão em voga, não avaliam nada. Provavelmente, a British Petroleum tinha todas as certidões de qualidade total quando causou a mais grave tragédia ambiental que se tem notícia nos EUA; as mega instituições financeiras americanas mantinham seus funcionários sobre os mais rígidos controles de qualidade antes de quebrarem o mundo; os frequentes recalls da indústria automobilística seguem o mesmo caminho.

As avaliações individuais, consideradas por Lazear como as melhores embora mais trabalhosas, espalham medo perene entre os trabalhadores, que estão sós, estressados e apavorados com os resultados. Além disso, quebram os laços de solidariedade e coletividade, base do movimento sindical e fonte da resistência às condições laborais precárias. Fortalecem o individualismo, a concorrência generalizada, a deslealdade.

Muitas vezes essas avaliações são acompanhadas de exposições vexatórias dos piores colocados, rankings que constrangem todos ao máximo, punições ou agressões verbais.

A despeito das críticas, a atribuição de metas absurdas que não conseguem dar conta das particularidades locais ou individuais é padrão nas grandes empresas e nos grandes bancos. O seu cumprimento ou não é o fundamento de uma promoção ou rebaixamento, de um remanejamento ou reformulação total.

É comum as organizações classificarem suas agências ou filiais de acordo com os resultados obtidos à luz de suas metas: há a agência de nível 1, 2, 3 ou 4, nível ouro, prata ou bronze etc. Os trabalhadores são submetidos à pressão total com metas explosivas colocadas em suas mesas e avaliação contínua de seu desempenho. Buscam a qualidade total independente do custo humano.

O controle psicológico dos trabalhadores pela sua mobilização subjetiva associado aos métodos de avaliação de desempenho baseados em metas e qualidade total ensejam a prática de assédio moral organizacional, o que se encontra em um nível muito mais danoso do que o assédio moral interpessoal.

A associação desses dois elementos obedece aos objetivos empresariais e atendem a uma nova forma de organizar os recursos humanos à base da pressão psicológica com efeitos lesivos à saúde mental e física dos trabalhadores e à dignidade destes. O ambiente de trabalho torna-se um estorvo pela situação de completa degradação moral que impera.

A captação desse fenômeno pelo direito configura um importante mecanismo para combatê-lo. 


\subsection{A Apreensão Jurídica do Assédio Moral}

Após a constatação da existência do problema, o assédio moral tornou-se objeto de estudo das mais variadas ciências: psicologia, medicina, economia, administração, direito. A novidade era deveras impactante para as relações entre capital e trabalho e merecia a atenção de pesquisadores de várias matizes.

De outro lado, os trabalhadores organizados em torno de suas entidades sindicais iniciaram mobilizações com o intuito de denunciar o assédio moral publicamente e lutar contra sua prática, entrando em conflito aberto com as organizações empresariais como não poderia deixar de ser.

Sempre que o conflito capital $\mathrm{x}$ trabalho se acirra, o Estado intervém através do Direito para evitar que haja uma crise na economia mais grave que inviabilize a continuidade regular do sistema produtivo. Em outras palavras, o Direito apreende o conflito em acordo à interpretação de sua ordem sistemática, traduz o conflito que surge na base econômica para o mundo jurídico.

Via de regra, esse movimento se dá nesse sentido: da economia para o direito. Com o assédio moral, não foi diferente - muito embora a psicologia tenha sido fundamental para fazer o meio-de-campo entre o econômico e o jurídico. Em uma formulação esquemática, pode-se dizer que a) práticas sistemáticas de agressão moral ocorriam(em) no seio econômico, nas relações laborais; b) estudos de psicólogos constataram a degradação moral resultante e tornaram públicas tais práticas e c) o Direito captou o conflito e se propôs a resolvê-lo de forma a impedir o acirramento do conflito.

As informações sobre leis que combatem o assédio moral nas relações de trabalho a seguir descritas foram extraídas dos livros de Márcia Novaes Guedes (2008) e Freitas, Heloani e Barreto (2009).

Como os estudos sobre o mobbing iniciaram-se na Suécia, é justamente nos países escandinavos que se localizam as primeiras normas legais para combatê-lo. Esses países têm uma forte tradição social-democrata, com um vigoroso movimento sindical, que lhes confere uma peculiar construção de distribuição de renda e justiça social reconhecidos mundo afora. 
Frise-se que, antes mesmo dos estudos conduzidos por Leymann, Dinamarca (1975), Noruega e Suécia (1977) já possuíam legislações a afirmar que um ambiente de trabalho degradado tem conseqüências nefastas à saúde dos trabalhadores.

O Ministério da Saúde e Segurança sueco publicou resolução em 1994 adotando medidas contra "ações recorrentes, reprováveis ou claramente hostis ocorridas no confronto de trabalhadores singulares, de modo ofensivo e capazes de determinar o seu afastamento da coletividade e que opera no local de trabalho". Percebe-se claramente a definição leymanniana de mobbing aqui adotada.

Essa resolução administrativa é encarada como a primeira norma a respeito do mobbing. Responsabilizava as empresas pela organização do trabalho em respeito à segurança física, técnica, psicológica, social e organizativa dos empregados. Preceituava a prevenção das perseguições psicológicas com a participação dos trabalhadores e indicava pontos a ser considerados, como a explicitação da reprovação de tais condutas na empresa, a identificação de problemas ou sintomas que permitiriam a ocorrência do assédio, as medidas de combate à prática e apoio à vítima. Atualmente, o assédio moral é também penalmente tipificado na Suécia.

Na Noruega, desde 1977 já dispõe de um comando genérico trazido em uma lei do ambiente de trabalho dispondo que "os trabalhadores não serão submetidos ao assédio ou qualquer outro conduta inconveniente", incorporada posteriormente ao Código de Trabalho local em 1994. A forma genérica adotada aqui deu-se por uma opção de combater todas as formas de discriminação, permitindo com esse comando uma proteção ampla. Outrossim, em 1993 um julgado da Suprema Corte estabeleceu a definição de mobbing leymanniana e reconheceu o direito do trabalhador em ser ressarcido pelos danos físicos e psíquicos.

O Código de Trabalho Português, saudado como referência na proteção da dignidade do trabalhador, trata do assédio moral embora de forma genérica no bojo de várias discriminações, o que lhe leva alguns autores a criticar esse ponto. Há um projeto de lei no congresso específico sobre o tema bem mais rigoroso, prevendo inclusive a ocorrência de assédio moral organizacional.

A Inglaterra dispõe do Protection from Harassment Act de 1997, que prevê indenização ao agredido, aplicação de multa ao agressor e a possibilidade deste ser preso por até seis meses. Há a faculdade de um acordo ser celebrado entre as partes envolvidas visando a cessação dos ataques, subindo a pena para cinco anos em caso de descumprimento. 
O Código Civil italiano prevê a proteção à dignidade do empregado e a reparabilidade por dano moral. Há a possibilidade de conciliação no caso de assédio moral. Não obstante, desde 1999 a jurisprudência italiana vem abordando o tema, a partir do caso de uma empregada que entrou em depressão após perseguição e humilhação repetidas cometidas por seu chefe.

Na França, há a Loi de Modernisation Sociale aprovada no parlamento em 2002. Fortemente influenciado por Hirigoyen, dela utiliza o conceito de assédio moral em seu capítulo IV. Incentiva a conciliação interna na ocorrência de assédio, mas prevê prisão de até um ano, multa de até 15 mil euros e inversão do ônus da prova no caso de processo. Responsabiliza o empregador pela vigilância das condições de trabalho, prevenção e punição ao agressor.

Espanha, Alemanha e outros países utilizam a interpretação sistemática de sua legislação para combater o assédio moral. A União Européia tem recomendação para que os países se debrucem sobre o tema com vistas a uma futura uniformização legislativa.

Os Estados Unidos da América são a sede do capitalismo mais desenvolvido do planeta. Por consequiência, tem a burguesia mais poderosa e a ideologia liberalindividualista mais enraizada, onde os trabalhadores sequer têm o direito à sindicalização e as regras de proteção laboral são insignificantes. Não é à toa que um movimento como o Tea Party ganha tanta força em tão pouco tempo com suas histeria anti-comunista.

Nos EUA, onde 3 mil trabalhadores se suicidam anualmente por conta de assédio moral, os tribunais utilizam o Civil Rights Act de 1964 para combater o mal. Porém, este se faz de forma bem recuada, com três pré-requisitos: a gravidade da conduta, a repetição dos ataques e a sua influência na produtividade do trabalhador. Este último requisito permite questionar se isso é uma forma de proteger o trabalho ou o capital...

Na América Latina, há projetos de leis regulamentando o tema tramitando em diversos parlamentos nacionais, sugerindo punições a empresas e indivíduos infratores, incentivos a organizações que o previnam, conciliações etc. A despeito da escassez legislativa, a jurisprudência tem resolvido o problema a seu modo, interpretando sistematicamente a legislação e tutelando a dignidade dos empregados.

No Brasil, há algumas leis estaduais e municipais a combater o assédio moral no âmbito da administração pública. O pioneirismo é atribuído ao Rio de Janeiro, com uma lei aprovada em 2002 proposta por um deputado do Partido Socialista Brasileiro. 
Também em 2002, o município de São Paulo aprovou uma lei de iniciativa de um vereador do Partido dos Trabalhadores dispondo sobre aplicação de penalidades a servidores municipais que cometam assédio moral. $O$ estado paulista teve duas oportunidades de aprovar leis semelhantes propostas por deputados do PT em 2002 e 2007, mas os governadores do PSDB vetaram ambas.

Tais normas são de Direito Administrativo, o que quer dizer que, embora absorvam institutos e definições do Direito do Trabalho, aplicam-se somente a servidores estaduais e municipais, uma vez que somente o Congresso Nacional pode legislar sobre as relações entre capital e trabalho.

Constata-se que a proposição legislativa para o combate ao assédio moral, no Brasil e ao redor do mundo, via de regra cabe a partidos de esquerda, englobando aqui socialistas, social-democratas, trabalhistas ou comunistas. Lado outro, a rejeição ou veto a tais leis dão-se pelos partidos de direita.

Esse registro é uma obviedade, na medida em que os partidos de esquerda tem origem na classe trabalhadora, encontrando sua força nos movimentos sindicais e organizações de outras classes subalternas. Movimento inverso é encontrado nos partidos de direita, cuja força reside nas classes dominantes e são os canais preferenciais do capital ao parlamento.

2.6 O Assédio Moral Organizacional Captado pelo Direito Brasileiro

A apreensão jurídica do assédio moral no Brasil deu-se de forma semelhante à boa parte dos países em que a iniciativa coube à jurisprudência. Uma interpretação sistemática da Constituição e do Direito Privado possibilitou a aplicação do instituto antes mesmo de uma positivação expressa por parte do parlamento.

A definição jurídica do assédio moral é absorvida de outros ramos da ciência já observados. Compreende-se por este o conjunto de ações ou omissões, em suas mais diversas formas, que configurem o ataque sistemático a um ou mais indivíduos com a conseqüente destruição física e psíquica deste(s) e a degradação do ambiente de trabalho.

As formas como ocorrem o assédio moral são narrados fartamente na literatura especializada e facilmente encontradas em uma rápida busca jurisprudencial na internet. 
Um grupo de colegas que sabota um dos seus pares temendo sua ascensão; uma empresa que isola empregados para que estes peçam demissão; um chefe ególatra que agrida em público um seu subordinado desproporcionalmente. São inúmeras as possibilidades de ocorrência de assédio moral.

O elemento central sempre destacado para sua configuração é o caráter sistemático dos ataques. Conforme observa Amauri Mascaro Nascimento (2009, p. 518), o assédio moral pressupõe "reiteração, comportamento, prática que se repete. O assédio moral é uma série de atos cuja tipificação não é definida em lei”.

Além de afirmar a centralidade da reiteração dos ataques para definir o instituto, Nascimento evidencia o fato de que o Brasil não dispõe de uma lei própria para defini-lo, o que não é um empecilho para sua aplicação, uma vez que a legislação vigente permite o seu combate pelos magistrados. Ademais, são tantos os exemplos que, em nenhuma hipótese, o ordenamento jurídico poderia tipificar a totalidade dos atos que ensejem a condenação por assédio moral.

Melhor que tipificar tais atos, é analisar os casos concretos para pode auferir a existência ou não do assédio. As práticas reiteradas são aceitas medianamente pela sociedade? Sua ocorrência trouxe algum grau de degradação psicofísica ao agredido? A partir da constatação da repetição dos ataques e de seus impactos subjetivos, declara-se a existência do assédio e defere-se a sua reparação.

Compreende-se, assim, como as características definidas inicialmente pela psicologia são apropriadas pelo Direito. A ação ou omissão destrutiva é a base, o ato, o conteúdo do assédio moral. A sobrecarga de trabalho para que a vítima não consiga cumprir suas tarefas e seja recriminada, gritos em público contra um empregado vulnerável, acusações levianas são exemplos de atos do assédio. A omissão por parte da empresa ou dos chefes também.

O caráter sistemático é o ponto comumente mais ressaltado pela doutrina e jurisprudência trabalhista. A agressão não pode ser um ato isolado, tem que ser repetido. Não que um ataque único não configure um dano reparável, mas não constitui assédio que, conforme já debatido, pressupõe reiteração, comportamento. Observe-se o constante nos fundamentos do seguinte acórdão.

(...) O assédio moral verifica-se quando ocorre exposição do trabalhador a situações constrangedoras e vexatórias de forma continuada e sistemática, a 
ponto de desestabilizá-lo moral e fisicamente, em verdadeira agressão à dignidade da pessoa humana (...). Processo 0182400-49.2009.5.04.0771. TRT da $4^{\mathrm{a}}$ Região, $8^{\mathrm{a}}$ Turma. Relator: Denis Marcelo de Lima Moralinho. 16/06/2011.

O impacto subjetivo é consequiência do assédio. Este não é uma doença, mas acarreta várias. Depressão, insônia, crises de choro são exemplos de degradação psíquica por que passam as vítimas. Emagrecimento, vulnerabilidade a doenças, Lesão por Esforço Repetitivo são degradações físicas.

A degradação do ambiente de trabalho também deve ser levada em conta. Um local de trabalho onde o assédio é a tônica mantém todos os empregados, mesmo os que não são alvo imediato do assédio, sob constante pressão, temerosos de ser a bola da vez. O desrespeito ao trabalhador é incompatível com um ordenamento jurídico que preze pela dignidade e pelas garantias contra excessos do poder diretivo patronal.

A degradação do ambiente laboral talvez seja um definidor mais importante que a degradação da saúde do trabalhador. Não é preciso quebrar a perna do atacante para que o juiz apite falta. Um jogador que profira um carrinho mostrando a sola da chuteira pode ser punido com cartão amarelo mesmo que sequer atinja o adversário. Da mesma forma, não é preciso que o indivíduo seja acometido de depressão profunda para que se constate que foi assediado. O impacto subjetivo pode ser definidor do valor da indenização, mas o assédio é definido de fato pelas agressões, e não pelo agredido.

\footnotetext{
Importa mencionar que não é necessário o dano explícito ou o adoecimento caracterizado para configurar o assédio moral. $O$ que se pune é o comportamento, a conduta abusiva (...) para caracterizar o assédio moral basta demonstrar o desvio ou abuso de comportamento do assediador, independente de ter gerado ou não conseqüências à saúde do trabalhador (OLIVEIRA, 2010, p. 200).
}

A par dessas características, pode-se afirmar que o assédio moral no trabalho é toda prática, omissiva ou comissiva, reiterada sistematicamente contra um ou vários empregados com a consequiente degradação do ambiente laboral e que tende a desestabilizar a saúde física ou psíquica do(s) indivíduo(s).

Pelas relações de força estabelecidas pela hierarquia empresarial, oriundas do poder diretivo, a ocorrência mais freqüente de assédio moral é o descendente, aquele que ocorre 
de um superior hierárquico para um inferior. A subordinação a que está, contratualmente, submetido o empregado e o poder de dirigir a prestação do serviço conferido ao empregador facilitam que o exercício deste poder diretivo seja extrapolado e enseje o assédio moral.

Porém, não é raro que o assédio dê-se na modalidade horizontal, entre profissionais de mesma hierarquia. Um grupo de empregados pode, por exemplo, discriminar insistentemente um indivíduo ou, até mesmo, sabotar o seu trabalho, ou por inveja e medo de que este ascenda profissionalmente com mais facilidade que os agressores ou por puro preconceito, racismo, homofobia, machismo.

Mais difícil de constatar, embora não impossível, é o assédio moral ascendente, que ocorre de baixo para cima na hierarquia empresarial. Um novato desavisado que assuma função de chefia pode despertar a ira do grupo que trata-o com desleixo, descumpre as tarefas propositadamente, sabota a autoridade do chefe para deslegitimá-lo.

Independente da verticalidade ou horizontalidade do assédio, fato é que o Direito realça o aspecto sistemático enquanto diferencial caracterizador do assédio moral. Isso porque uma única agressão pode ensejar um dano moral e sua indenização, enquanto que, para que haja a reparabilidade civil por assédio moral no trabalho, necessário se faz a repetição das agressões, que é a repetição do dano moral.

A Constituição Federal de 1988 sacramentou, no art. 5º V, que "é assegurado o dá direito de resposta, proporcional ao agravo, além da indenização por dano material, moral ou à imagem". Com isso, encerrou anos de debate que mobilizava doutrina e jurisprudência acerca da possibilidade de haver reparação de natureza moral no Direito brasileiro.

É importante frisar que a conceituação do assédio como "moral" tem significados distintos para a psicologia e para o direito. Hirigoyen afirmava cabalmente que o assédio é moral porque diz respeito a noções de bem e mal, de comportamentos aceitos ou não socialmente, em virtude do sentimento de injustiça que acometia as vítimas.

Para o direito, o moral se contrapõe ao patrimonial, uma vez que, historicamente, as reparações previstas pelos ordenamentos jurídicos - e o brasileiro não foge è regra diziam respeito tão somente a prejuízos de natureza patrimonial, econômico, pecuniário. $\mathrm{O}$ dano moral é uma evolução que aponta para novas perspectivas de proteção pessoal.

A partir do momento em que a possibilidade da reparação moral de um dano é declarada, permitiu-se que o mesmo ocorresse com o assédio moral. Na realidade, o 
assédio moral é um conjunto de danos morais, é a repetição de agressões com esta natureza contra um alvo determinado. O contrário não ocorre: o dano moral pode consumar-se com um único ato, um único ataque que tenha impactos na subjetividade do indivíduo.

É por isso que o Direito do Trabalho trata de forma tão enfática a reiteração enquanto elemento caracterizador do assédio. A repetição dos ataques é o que permite diferir-lhe do dano moral, que o engendrou.

\footnotetext{
Ampliando a interpretação, é possível afirmar que o assédio moral (e, por extensão, o sexual) é uma categoria ou espécie de dano moral que, devido a sua forma de expressão, temporalidade e freqüência, apresenta singularidades. $\mathrm{O}$ dano moral é gênero (FREITAS, HELOANI, BARRETO, 2009, p. 91).
}

Esse é um dos aspectos que diferencia a apreensão jurídica do assédio moral em relação à apreensão psicológica do fenômeno. Cada ramo das ciências humanas terá suas idiossincrasias, suas vicissitudes, o que traz a possibilidade de nuances diversas mesmo que se trate de um mesmo instituto comum a ambos os ramos da pesquisa.

O dano, no que diz respeito ao Direito, constitui-se na lesão que um ato ilícito de outrem tenha causado em interesse alheio juridicamente tutelado, em virtude de dolo ou culpa daquele. Sua previsão consta no Código Civil que assim o prevê: "art 927. Aquele que, por ato ilícito (arts. 186 e 187), causar dano a outrem, fica obrigado a repará-lo”.

Quatro elementos caracterizam o dano reparável: a ação ou omissão voluntária, que seria a ação ensejadora; o elemento subjetivo culpa, sendo essa a negligência ou a imprudência; a causalidade, que seria a relação de causa e efeito entre a ação e o dano; e o dano em si, o prejuízo suportado motivado pela ação.

Além da previsão constitucional já observada, o Código Civil reafirma a possibilidade moral de dano ao definir o ato ilícito em seu art. 186: “aquele que, por ação ou omissão voluntária, negligência ou imprudência, violar direito e causar dano a outrem, ainda que exclusivamente moral, comete ato ilícito".

Esse dispositivo é cristalino ao ressaltar que o dano pode ser meramente moral. $\mathrm{O}$ dano pode ser moral por exclusão ao dano material. Distinguem-se pelo interesse juridicamente tutelado ofendido: o objeto da lesão foi patrimonial/econômico ou moral/pessoal? 
A evolução histórico-jurídica trouxe novidades alvissareiras. Já está assentado, por exemplo, que o dano não necessariamente ocorre contra um indivíduo, sendo reconhecida a possibilidade de ocorrência de dano moral coletivo. Particularmente a partir da aprovação do Código de Defesa do Consumidor (Lei 8.078/90), os direitos difusos, coletivos ou individuais homogêneos ganharam contornos bem definidos que permitiu uma aplicação do direito mais em acordo à atualidade.

Um dano moral difuso seria toda agressão decorrente de ato ilícito que ofenda direitos pessoais transindividuais cujos lesados seriam pessoas indeterminadas, ligadas por circunstâncias de fato. Tal dano seria indivisível, ou seja, a lesão a direito de um equivaleria à lesão a direito de todos, da mesma forma que sua reparação.

Um dano moral coletivo também seria transindividual e indivisível, e atingiria, pela definição legal, um grupo, categoria ou classe de pessoas que mantivessem entre si ou com o agressor uma relação jurídica base. Há uma relação jurídica que une o grupo, neste que é considerado o direito coletivo stricto sensu.

O dano moral individual homogêneo é decorrente de um ato ilícito comum, o que lesionaria direitos de diversas pessoas. Pode-se dizer que ofenderia um feixe de direitos individuais de pessoas determinadas, sendo que o dano e o seu causador são os mesmos.

O dano moral coletivo, nas três modalidades, permite que a reparação dê-se de forma unificada, facilitando o acesso à justiça na medida em que resolve diversas ofensas morais de uma vez só.

Os titulares do direito de reparação dos danos coletivos (stricto sensu) são as pessoas jurídicas constituídas em sociedade ou associações; os dos individuais homogêneos, as pessoas que tem interesses decorrentes de origem comum; os dos difusos, a comunidade (OLIVEIRA, 2010, p. 68).

Outro avanço considerável diz respeito à responsabilização da pessoa jurídica. $\mathrm{O}$ dano causado por pessoa física é o mais antigo e tradicional e não merece maiores transgressões: o indivíduo que comete um ato ilícito e causa dano a direito de outrem deve reparar o prejuízo causado.

A pessoa jurídica passou a ser responsabilizada também por seus atos e tornou-se sujeito ativo (e passivo) de dano moral. Não há mais debate a esse respeito: a "realidade sociológica" que adquiriu personalidade age em nome próprio por conta de seus interesses. 
Os danos cometidos a alheios devem ser reparados pela pessoa jurídica que cometeu a ilicitude.

O reconhecimento deste instituto é fruto de uma evolução no Direito forçado pelo mundo real da economia. As sociedades, associações ou fundações têm vida própria, com nome, patrimônio, interesses. Mesmo que seus prepostos lhes representem, é a pessoa jurídica em si que está atuando, se relacionando com o mundo.

Logo, não há motivo para não considerar a hipótese de a pessoa jurídica cometer uma ilicitude e acarretar um dano moral. Neste caso, deve reparar o dano como não poderia deixar de ser.

A responsabilidade subjetiva ocorre quando o dano é cometido diretamente pelo autor que lhe causa. Para que seja concretizado, é necessário que o autor tenha agido com dolo ou culpa, entendendo-se esta como a negligência ou a imprudência. Pela teoria clássica de Direito Civil, a regra é que o individuo haja com dolo ou culpa para caracterizar o dano.

Ocorre que, em diversas situações, pode não haver o animus de causar o dano, o que dificultaria a reparação se o direito ficasse condicionado ao dolo ou à culpa. Por isso, para facilitar a vida de quem teve um direito seu ofendido por um dano moral, surgiu a figura da responsabilidade objetiva.

A responsabilidade objetiva independe de culpa ou dolo. Aquele que, pelo simples exercício de sua autoridade, expõe terceiros ao risco de ocorrência de um dano, responde por este mesmo que não tenha culpa. Basta, apenas, que se comprove a relação de causaefeito entre o ato e o dano. Está prevista no parágrafo único do art. 927:

Parágrafo único. Haverá obrigação de reparar o dano, independentemente de culpa, nos casos especificados em lei, ou quando a atividade normalmente desenvolvida pelo autor do dano implicar, por sua natureza, risco para os direitos de outrem.

A responsabilidade objetiva verifica-se em duas hipóteses: ou quando prevista em lei ou quando o mero exercício da atividade de uma entidade qualquer, por si só, representar risco de causar danos a terceiros. Neste caso, será a entidade responsável por qualquer dano causado, mesmo que sua conduta não tenha sido culposa, já que sua 
atividade representa naturalmente um risco. Surgiram então duas importantes teorias do risco: o risco proveito e o risco criado.

Pela teoria do risco proveito, é reparável todo dano causado a terceiros oriundo de uma atividade realizada em proveito do responsável. Quem aufere lucros de uma atividade econômica que cause risco de violação da saúde, da personalidade de outrem será onerado pelos danos causados. A obrigação de indenizar decorre do simples aproveitamento da atividade.

A teoria do risco criado vai além. O simples fato de haver um risco a outrem gera a responsabilidade de quem exerce a atividade. Esta teoria abarca toda e qualquer ação que ponha terceiros em risco mesmo que nenhum benefício tenha sido auferido.

Um avanço além em matéria de dano moral decorre do instituto do abuso do direito ou uso irregular do direito. Embora, a priori, esteja-se utilizando um direito subjetivo, excede-se à sua finalidade social, rompendo a barreira da licitude. Está contido no art. 187 do Código Civil: "também comete ato ilícito o titular de um direito que, ao exercê-lo, excede manifestamente os limites impostos pelo seu fim econômico ou social, pela boa-fé ou pelos bons costumes".

Ao exercitar as prerrogativas previstas pela legislação, não se pode desobedecer os fundamentos e as finalidades a que o direito se presta, sob pena de lesar terceiros e incorrer em dano contra estes, o que configuraria uma ilicitude. Mesmo o uso de um direito legitimamente conferido, pode-se extrapolá-lo e incorrer em dano por violar sua finalidade.

O surgimento desse instituto está ligado á crença de que todo direito existe em função de uma finalidade, ou seja, é um meio e não um fim, o que impediria o seu uso em detrimento do direito de outrem. Se o seu uso prejudica alheio, causa-lhe um dano, tem-se que o direito foi exercido de forma irregular, excessiva, abusiva. Se isso ocorre, haverá a responsabilidade e a reparação.

A despeito de o dano moral ser uma construção de direito civil, é inegável sua utilização em sede trabalhista, nas relações entre empregado e empregador. É mais do que freqüente a ocorrência de dano moral por parte das empresas contra os seus empregados, em diversos momentos da contratualidade trabalhista.

Despiciendo aprofundar aqui a ocorrência do dano moral nas relações de emprego, uma vez que trata-se de assunto devidamente superado. O dano moral é só mais um instituto previsto em direito civil absorvido pelo direito do trabalho. O ordenamento 
jurídico nacional é único, embora departamentalizado em diversos ramos (constitucional, penal, civil, trabalhista etc.), o que lhe confere uma sistematicidade e interação constantes.

O modo como essa migração ocorreu lhe indica. A partir da Constituição de 1988, passou-se a observar o dano moral nas relações de emprego. No início, a matéria era discutida na justiça estadual comum, o que denota que era encarado como matéria de direito civil ainda que se tratasse de uma relação empregatícia, de um dano causado por um empregador ao empregado.

Em um determinado momento, surgiu uma divergência onde tanto a justiça estadual comum quanto a justiça especializada do trabalho avocavam para si a competência de julgar dano moral na relação de emprego. O que se discutia era a predominância do caráter civil do dano à personalidade ou do caráter trabalhista da relação de emprego.

A querela foi suprimida em 1991 quando de um acórdão relatado pelo Ministro do STF Sepúlveda Pertence deliberou que é competência da justiça especializada julgar conflitos oriundos de relação empregatícia, ainda que se trate de matéria civilista.

Admite-se atualmente a ocorrência de dano moral nas diversas fases do contrato de emprego: antes, durante e depois de sua celebração.

Fala-se em dano moral na fase pré-contratual nos momento de seleção e puntuação. Diversas são as modalidades de seleção de uma empresa: exame de currículo, exames médicos, avaliações de competência, provas escritas e práticas. Já aqui pode se ofender a personalidade dos candidatos com a exigência de informações íntimas em demasia ou a discriminação explícita por questões de raça, gênero, orientação sexual etc.

A fase de puntuação é aquela onde ocorrem tratativas com vistas à celebração contratual. Revela-se a intenção de contratar e as condições do acordo começam a se delinear. Também aqui pode ocorrer dano com o vazamento indevido de uma informação que deveria ter sido mantida em sigilo. Ademais, ao criar-se a expectativa do emprego, pode ser que o candidato abdique do emprego anterior, realize despesas outras e venha a ter a contratação frustrada. Não é em caráter absoluto, mas pode ocorrer de o empregador ter criado uma expectativa além do que devia e ser responsabilizado por danos que sofra o candidato.

A fase pré-contratual é o momento mais difícil de se perceber a ocorrência de dano como não podia deixar de ser. A empresa tem a liberdade de contratar quem quiser, mas isso não pode ser feito à revelia do Direito, não pode fazê-lo com mecanismos não 
amparados legalmente. Tenha-se em mente que quem procura emprego está, muitas vezes, em estado de fragilidade, de necessidade.

Mais fácil é observar o dano pessoal durante a execução do contrato de emprego. $\mathrm{O}$ poder diretivo do empregador e a subordinação do empregado constituem uma combinação explosiva que facilmente descamba para o abuso de poder.

O poder diretivo do empregador é um instituto controverso, tanto na forma quanto o conteúdo de suas categorizações acadêmicas. Foco permanente de tensões nas relações capital-trabalho, muitas vezes é extrapolado em seu exercício, atingindo a dignidade do trabalhador e dando ensejo a reclamações por danos morais.

Seu conceito não foi estabelecido diretamente pelo legislador, sendo apreendido na própria definição do empregador, estipulado no art. $2^{\circ}$ da CLT: “considera-se empregador a empresa individual ou coletiva, que, assumindo os riscos da atividade econômica, admite, assalaria e dirige a prestação pessoal de serviço".

Ao estabelecer que o empregador dirige a prestação do serviço, a CLT está conferindo a este a capacidade de determinar o conteúdo da prestação do serviço do empregado; em outras palavras, está conferindo ao empregador o poder diretivo.

O poder diretivo pode ser conceituado, assim, como o conjunto de prerrogativas asseguradas legalmente ao empregador para determinar o conteúdo concreto da prestação da atividade laboral por parte do empregado. Se este vende a sua força de trabalho à empresa em troca do salário, de tal forma que a empresa se apropria desta mercadoria trabalho para o seu acúmulo de capital, é esta empresa que dirá como esse trabalho será aproveitado.

A partir do momento em que o empregado se apresenta enquanto trabalhador subordinado, ele está alienando a sua força de trabalho à empresa, que o dirigirá em acordo com os demais elementos objetivos da produção e reprodução do capital. O empregador determina onde o empregado atuará, quais serão as suas tarefas, a sua função dentro da empresa, enfim, o conteúdo da sua prestação.

Em uma sociedade onde o trabalho é social e a propriedade é privada, ou seja, onde os produtores diretos atuam coletivamente, com ações as mais simplificadas possíveis para que aumente a sua produtividade, e todo esse trabalho coletivo é apropriado pelo empregador, o poder diretivo erige-se como uma necessidade que garante o máximo de aproveitamento do trabalho apropriado. 
A centralização do poder diretivo na figura do empregador diz respeito a essa contradição do capitalismo - trabalho social e propriedade privada. Porém, a organização da atuação dos trabalhadores impõe-se como exigência histórica de produtividade.

Friedrich Engels, um dos precursores do socialismo científico, trata do tema já no século XIX em um debate sobre a autoridade. Engels afirma que as condições objetivas de produção no capitalismo substituem acentuadamente a ação individual dos trabalhadores por sua ação combinada. A grande indústria assumiu o lugar das pequenas oficinas, assim como os grandes meios de transporte assumindo o lugar dos pequenos.

\footnotetext{
Em todo o lado a ação independente dos indivíduos é substituída pela ação combinada, a complicação dos processos interdependentes (...) Querer abolir a autoridade na grande indústria, é querer abolir a própria indústria, é destruir a fiação a vapor para voltar à roca de fiar (ENGELS).
}

Engels dá alguns exemplos sobre essa necessidade de organização na produção. $\mathrm{Na}$ nascente indústria têxtil, por exemplo, ele demonstra como o funcionamento das máquinas necessita da combinação do trabalho dos indivíduos, que devem operá-las, consertá-las eventualmente, trazer a matéria-prima, deslocar o material produzido. Tudo isso depende de que todos tenham suas funções pré-definidas, que acordem seus horários.

Quando um imprevisto ocorre, há que se tomar uma decisão acerca da melhor solução para evitar que se interrompa a produção. Independente de onde venha essa decisão, se do engenheiro da fábrica ou de uma assembléia de trabalhadores, existirá uma fonte de autoridade que consiga organizar esse tipo de produção em grande escala.

\footnotetext{
Acabamos, pois de ver que, por um lado, certa autoridade, atribuída não importa como, e, por outro lado, certa subordinação são coisas que, independentemente de toda a organização social, se impõem a nós devido às condições nas quais produzimos e fazemos circular os produtos (ENGELS).
}

Essa autoridade era encarada por Engels como uma necessidade da organização social do trabalho, uma racionalidade para a produção. O poder diretivo nos moldes atuais surge quando desloca-se essa fonte de autoridade para a pessoa do empregador. E, nesse aspecto, Taylor e suas teorias representam um marco. 
O taylorismo representa um método de aumento da produtividade através da racionalização do tempo gasto no trabalho, maximizando a atuação do trabalhador nas fábricas e evitando desperdício.

Taylor trabalhara em diferentes posições numa fábrica antes de tornar-se engenheiro. Ele praticou a observou as práticas profissionais dele e de seus colegas para fundar a sua teoria de administração. E isso quando o capitalismo entrava na sua fase monopolista, em que as indústrias concentravam uma quantidade de empregados nunca antes vista.

A partir disso, ele planejou formas de simplificar ao máximo a atuação de cada trabalhador individualmente considerado, de forma que cada um pudesse repetir seus atos o maior número de vezes por dia. Com isto, aumentava a produtividade de cada um e de todos.

Antes do taylorismo, as tarefas dos trabalhadores eram passadas oralmente dos mais velhos para os mais novos. E estas tarefas eram aprendidas empiricamente, sem nenhum planejamento. Isso dava poder aos trabalhadores, que podiam retardar o trabalho, tornandoo menos cansativo e forçando as empresas a contratar mais trabalhadores, o que reduziria o desemprego.

Para que os empregados não retardassem o trabalho propositalmente, Taylor propôs que uma gerência administrativa deveria centralizar o comando das tarefas dos obreiros, retirando-lhes essas definições. Para ele, as tarefas dos empregados deveriam deixar o empirismo a que eram submetidas e tornar-se "científicas", planejadas pela empresa visando aumentar a produtividade.

A divisão entre trabalho manual e intelectual já existia antes de Taylor. Porém, a partir dele, essa separação consumou-se totalmente na empresa, retirando qualquer atividade intelectiva dos trabalhadores, legando-os apenas o trabalho braçal mais simples. Com isso, operou-se uma transformação no mundo das organizações que definiria o poder diretivo do empregador tal como o Direito do Trabalho concebe-o atualmente.

(A subordinação) pode ser a inserção do prestador num sistema coordenado, em função dos interesses do empregador, no qual os atos de trabalho do empregado não são atos de escolha, mas atos de integração no processo produtivo ou nos serviços, exigidos pelas finalidades essenciais da empresa (GENRO, 1994). 
A história das organizações tornou o trabalho muito mais complexo e aumentou a participação do setor de serviços na economia em relação ao setor da indústria. $O$ taylorismo foi inevitavelmente superado por outras formas de gestão de recursos humanos, sendo o gerencialismo um exemplo disso. Entretanto, a direção do empregador e a subordinação do empregado permanecem.

A doutrina costuma dividir o poder diretivo em três elementos: o poder de organização, de controle e disciplinar. Esses seriam os três momentos em que o empregador exerceria a sua capacidade jurídica de dirigir a prestação do labor.

O poder de organização refere-se ao direito do empregador em integrar a prestação do empregador aos demais fatores de produção da empresa, ou seja, às condições objetivas do trabalho. Tal organização tem a ver com o aspecto econômico e social da empresa.

Nas palavras do professor Amauri Mascaro Nascimento (2009), “empresa é a organização complexa que combina os fatores da produção, de modo que ao empregador cabe dar a unidade no empreendimento, moldando-se para que cumpra as diretrizes a que se propõe".

Em sua gestão, a empresa pode ter uma estrutura social organizada em torno de uma diretoria, assembléia, conselho fiscal, assim como pode ter um regulamento interno, um quadro de carreira contendo as normas que garantem a promoção dos empregados e estipulam as suas funções.

Deve-se registrar que as questões relativas às condições de trabalho, como remuneração e jornada, sofrem influência tanto estatal, haja vista que a legislação trabalhista em seu conjunto estabelece cláusulas mínimas que devem ser observadas, quanto negocial, haja vista que os acordos e convenções coletivas são cada vez mais efetivados no Brasil.

A despeito destas intervenções estatais e coletivas, o poder diretivo é tido como uma faculdade do empregador, uma vez que a finalidade central de uma empresa capitalista é a acumulação de capital, que necessariamente favorece o proprietário.

Decorrência óbvia deste poder de organização é a faculdade de fiscalização do empregado por parte do empregador. O poder de controle garante, então, que o empregador poderá fiscalizar a execução das tarefas dos trabalhadores, cobrando-lhes resultado e empenho. Observa Nascimento (2009) que a atividade desenvolvida pelo obreiro, "sendo 
subordinada e mediante direção do empregador, não é exercida de modo que o empregado pretende, mas daquele que é imposto pelo empregador"

A empresa poderá controlar o tempo de trabalho com os cartões de ponto, poderá requerer prestações periódicas de conta ou determinado padrão de qualidade das tarefas, e outras formas mais tensas da relação capital-trabalho como as câmeras de vigilância.

Por fim, o poder disciplinar confere direito ao empregador de exercer diretamente a sua autoridade sobre o trabalho alheio, de sorte que torna-lhe possível aplicar sanções ao empregado faltoso, que não cumpra suas obrigações.

O direito brasileiro reconhece legalmente a suspensão de, no máximo, trinta dias, vaticinado pelo art. 474 da CLT e a dispensa por justa causa, fundamentalmente consubstanciada no art. 482 do mesmo documento consolidado. A advertência verbal ou escrita é admitida baseada na noção de quem pode o mais pode o menos. Por se tratar de uma penalidade mais branda do que as legalmente previstas, integrou-se no ordenamento jurídico trabalhista.

O poder diretivo não é um direito absoluto: encontra limites intrínsecos e extrínsecos. O contrato de emprego e o regulamento da empresa limitam intrinsecamente a direção do empregador, uma vez que devem ser observados e não podem ser extrapolados. Os limites extrínsecos são as acordos e convenções coletivas e o Direito.

São constantes as condenações de empresas por exigir que seus empregados se fantasiem, dispam-se na saída para revista íntima, tenham o tempo de ida ao banheiro controlada, ou seja, condenações por abuso do poder diretivo. Muitas dispensas por justa causa são revertidas judicialmente por também configurarem abuso.

Frise-se que o contrato de emprego não resume-se às relações patrimoniais da prestação do serviço e do pagamento salarial. É considerado também uma relação pessoal, o que assegura a proteção da dignidade da pessoa humana, os direitos de personalidade e a saúde do empregado. Além do mais, há que estabelecer uma relação de fidúcia envolvendo a boa-fé e a lealdade como nas demais relações de direito privado, o que envolve o compromisso de não enganar nem causar danos aos trabalhadores.

Por fim, o dano moral pode ocorrer no momento da rescisão do contrato de emprego. A Constituição Federal em seu art. $7^{\circ}$, I preceitua como direito dos trabalhadores "relação de emprego protegida contra despedida arbitrária ou sem justa causa, nos termos de lei complementar, que preverá indenização compensatória, dentre outros direitos”. É certo que essa lei complementar nunca veio, o que constitui grave omissão legislativa. 
Dispõe o art. 165 da CLT que "os titulares de representação dos empregados nas CIPA (s) não poderão sofrer despedida arbitrária, entendendo-se com tal a que não se fundar em motivo disciplinar, técnico, econômico ou financeiro".

A Convenção 158 da OIT dispõe que

Art. 4 - Não se dará término à relação de trabalho de um trabalhador a menos que exista para isso uma causa justificada relacionada com sua capacidade ou seu comportamento ou baseada nas necessidades de funcionamento da empresa, estabelecimento ou serviço.

A ratificação da Convenção 158 pelo Congresso Nacional é pauta do movimento sindical e tem ganhado força nos últimos anos. Ela já chegou a ser ratificada no início dos anos 90, mas foi denunciada no governo FHC.

O importante a observar aqui é que a CLT e a convenção 158 da OIT fornecem os elementos que caracterizariam a despedida motivada por motivo disciplinar ou incapacidade técnica do empregado, ou motivos econômicos, tecnológicos e financeiros do empregador. $\mathrm{O}$ art. 482 consolidado absorveu os motivos disciplinares que ensejam a dispensa por justa causa.

Infelizmente, sem a ratificação da citada Convenção da OIT, o poder de dispensa patronal continua intacto no Brasil, podendo ser efetivado sem qualquer mediação sindical e sem sequer exigir fundamentação, o que facilitaria a comprovação de danos morais. $O$ único senão imposto à dispensa imotivada é a multa de 40\% do FGTS estabelecida pelos Atos das Disposições Transitórias da Constituição, que de transitória não tem nada, uma vez que já dura desde 1988. Além disso, pode-se considerar que o art. 483 protege explicitamente a dignidade e os direitos da personalidade do empregado.

Outrossim, é reconhecida a proteção ao empregado contra dispensa abusiva, assim considerada aquela que exceder manifestamente os limites impostos ao poder diretivo. Qualquer dispensa gera dano ao empregado, por negar-lhe a continuidade do seu trabalho. Ao dano gerado pela dispensa tida por lícita, há a previsão de multa de 40\% do FGTS, o que equivale a um reconhecimento do dano e a sua reparação.

Ocorre que, sendo a dispensa abusiva, além do dano inerente ao rompimento do contrato de emprego, há um novo dano porque contrário à função social da empresa e lesivo à dignidade do trabalhador. "Num mesmo ato, atingem-se dois direitos distintos, um 
com a indenização prevista em lei, outro com outra indenização 'autônoma' pelo dano ilícito causado à personalidade" (OLIVEIRA, 2010, p. 148). Como exemplos de despedida abusiva, cite-se uma dispensa fruto de racismo ou homofobia. O assédio moral visando o pedido de demissão das vítimas também pode ser localizado aqui.

Pela análise das definições trazidas de assédio moral e da absorção do dano moral pelo Direito do Trabalho, é plausível afirmar que o assédio organizacional é plenamente aceito pela interpretação a aplicação deste ramo do direito. Indo mais além, pode-se afirmar que para o ordenamento jurídico vigente no Brasil, não há diferença entre o assédio moral interpessoal do assédio organizacional.

O assédio moral interpessoal é o conjunto de atos de agressão praticados sistematicamente, reiteradamente contra um ou mais indivíduos com o intuito de humilhar, constranger, excluir, causando impactos à saúde psicofísica da vítima. $\mathrm{O}$ assédio organizacional também consiste em práticas reiteradas de agressão moral ou pessoal, normalmente contra um grupo ou contra todos os empregados, só que inseridos no modelo de gestão da empresa, visando o aumento da produtividade, do lucro, a diminuição dos custos ou a exclusão do grupo.

Essas são definições extraídas de outras ciências do trabalho. Conforme já debatido, cada uma com suas particularidades em abordar o problema. Quando o direito se apropria deste instituto, também o faz ao seu modo, com as suas particularidades. O assédio moral, ao migrar para o direito, o fez mediado pelo instituto do dano moral, que é a conseqüência do assédio moral e o modo de combatê-lo.

\footnotetext{
O assédio moral contém dano, ou melhor, é uma constelação de danos morais (...) é possível afirmar que o assédio moral (e, por extensão, o sexual) é uma categoria ou uma espécie de dano moral que, devido a sua forma de expressão, temporalidade e frequiência, apresenta singularidades. $\mathrm{O}$ dano moral é gênero (FREITAS, HELOANI, BARRETO, 2009,p. 90 e 91).
}

Para estes autores, o assédio moral é "decorrente de um conjunto de danos morais com características e sinais específicos”. Amauri Mascaro Nascimento (2009, p. 516) afirma que o "dano moral, que é o efeito da agressão moral, do assédio moral e do assédio sexual, é um só e mesmo conceito, no direito civil e no direito do trabalho". O livro organizado por Gosdal e Soboll (2009, p. 69 e ss.) vai na mesma linha ao analisar que, dentre as medidas para combater o assédio moral, o trabalhador "pode pleitear o 
pagamento de indenização por dano moral ou material e mesmo a rescisão de seu contrato de trabalho por culpa do empregador".

Em linhas gerais, pode-se dizer que do assédio decorre um dano moral qualificado pela sua reiteração ao longo do tempo, o que pode trazer conseqüências mais gravosas. $\mathrm{O}$ assédio é a ação que dá causa ao dano reparável. A partir dessa associação do assédio pelo dano, conclui-se como perfeitamente cabível a possibilidade de ocorrência de assédio moral organizacional.

O assédio moral é o conjunto de atos processuais, sistemáticos, que perduram no tempo, que compõem uma totalidade de agressões morais que degrada as condições de trabalho e lesa a saúde psíquica e física da vítima. Os atos que compõem o assédio caracterizam a ação que tem relação de causalidade com o dano em si, qual seja, o abalo à saúde da vítima, encaixando perfeitamente nos elementos característicos do dano moral na relação de emprego. Analisando as diferenças entre assédio interpessoal e organizacional, percebe-se que todas elas são desimportantes para o direito.

A primeira diferença diz respeito ao agressor. $\mathrm{O}$ assédio interpessoal pode ser ascendente, descendente ou horizontal. $\mathrm{O}$ ascendente, mais comum, trata de um agressor hierarquicamente superior à vítima; o descendente, lado outro, trata de agressor hierarquicamente inferior. O horizontal, por fim, trata de agressor e vítima de mesma posição hierárquica, não há um maior que o outro.

O assédio organizacional terá sempre a empresa enquanto protagonista por meio de seus gestores que impõem mecanismos de gestão totalmente tiranizados. Pode-se dizer que é descendente, embora a organização em si seja a agressora. Só que essa age pelos seus gestores em nome de seus investidores no bom e velho esquema "manda quem pode, obedece quem tem juízo".

Além disso, quando o(s) trabalhador(es) ingressa(m) em juízo, o reclamado será sempre a empresa ou pela omissão em não ter interrompido o processo ou pela ação já que o estimulou. Logo, não importa se o agressor é um chefe sádico ou um chefe obediente aos objetivos da empresa, pois é esta que será responsabilizada pelos danos causados pelo assédio.

A própria evolução da responsabilidade civil e da teoria do risco depõe a favor do assédio organizacional. Inegável atualmente que a pessoa jurídica tem personalidade própria, vida autônoma. Embora representada por pessoas físicas, estas agem em nome 
daquela. Daí reconhece-se plenamente a possibilidade de a empresa causar dano a outrem e ser obrigada a repará-lo.

E mais: com a responsabilização objetiva, a teoria do risco indica a possibilidade de ocorrência de assédio moral organizacional. Se as atividades da empresa expõem seus empregados a riscos de estresse, de depressão por descumprimento de metas abusivas ou outros abalos psíquicos, de Lesão por Esforço Repetitivo, o assédio organizacional é plausível tanto pelo risco proveito quanto pelo risco criado.

Com um mínimo de ousadia hermenêutica, pode-se chegar à conclusão de que mesmo o assédio horizontal pode ser decorrente de assédio organizacional. Ao abusar das metas impostas e dos respectivos mecanismos de cobrança, a empresa estimula a competição de todos contra todos a favorece o surgimento do instinto de sobrevivência onde qualquer ética é abandonada e sabotar o trabalho de um colega pode significar a manutenção do emprego.

A responsabilidade objetiva anula outra diferença entre o assédio interpessoal do organizacional: a intencionalidade. Diz-se comumente que o assédio interpessoal visa constranger, humilhar, vexar ou excluir a vítima. Já o assédio organizacional visaria ou excluir um grupo ou reduzir custos ou aumentar a produtividade dos empregados sem necessariamente visar o dano causado. Nada disso interessa ao direito.

A responsabilidade subjetiva ainda é a regra para o direito civil com a verificação da culpa ou dolo. Mas responsabilidade objetiva torna desnecessário o animus ao se preocupar exclusivamente com a relação de causa e efeito entre a ação e o dano causado.

São freqüentes as condenações de empresas que expõem suas trabalhadoras às famigeradas revistas íntimas na saída do trabalho, quando estas chegam a despir-se por completo para provar que não furtaram nada, numa absurda inversão do princípio de que todas são inocentes até que se prove o contrário. O que a empresa quer com isso não é humilhar suas empregas por um máximo de sadismo; o que ela quer é não ter que se utilizar de dispositivos tecnológicos mais modernos e mais caros de controle das mercadorias. Ou seja, não há uma intenção deliberada de constranger, vexar. O que há é a vontade de não encarecer os custos da produção, aumentando os lucros em cima da dignidade alheia.

Quando um banco estabelece metas draconianas aos bancários não pretende proliferar o estresse, as lesões, a depressão e, até mesmo, o suicídio. O que ele quer é 
aumentar sua carteira de clientes e investidores e potencializar seus lucros em detrimento dos direitos de personalidade dos empregados bancários.

Empresas multinacionais comumente obedecem a comando das matrizes localizadas em países com sistema legal diverso. Há aquelas que não afastam empregados que desenvolvam doenças, não consideram acidente de trajeto como acidente de trabalho, combatem a sindicalização etc.

Tais exemplos ilustram movimentos de assédio moral que não podem ser interpretados como interpessoal, seja porque partem dos mecanismos perversos de gestão das organizações, seja porque não tinham o animus de humilhar, constranger, vexar. Tratase de casos explícitos de assédio organizacional e são plenamente absorvidos pelo ordenamento jurídico vigente.

Há momentos em que o assédio organizacional tem o elemento intencionalidade. Isso ocorre quando o objetivo de aumentar a pressão é excluir um grupo. As fusões e aquisições recentes de uma empresa sobre as outras trazem constantes exemplos disso. Quando duas empresas se fundem ou uma compra a outra, o enxugamento de pessoal é inevitável. Nesse caso, muitas impõem metas abusivas e discriminatórias sobre um grupo de empregados para forçá-los a pedir demissão, principalmente quando uma empresa privada adquire uma pública e os antigos servidores tornam-se alvo.

Outro exemplo de assédio organizacional com intencionalidade se dá quando uma empresa força a saída de um grupo especialmente tutelado pela legislação. Margarida Barreto analisa uma série de empresas que isolava trabalhadores que se afastavam junto à previdência social, acusando-os de frágeis, de fazer corpo mole ou de ganhar sem trabalhar.

\footnotetext{
Os "incapazes são separados dos "normais" e colocados à parte. Existem setores determinados "dos compatíveis" ou do "retrabalho, para onde são transferidos os reabilitados ou aqueles que mudam de função. Tais setores são conhecidos pejorativamente como "INPS", setor dos "inválidos", dos "podres" ou dos "inúteis" (BARRETO, 2006).
}

Essa modalidade de assédio é chamada por Márcia Novaes Guedes de mobbing estratégico, no qual a empresa organiza sua estratégia de forma que o empregado afaste-se por sua iniciativa como nos exemplos da "geladeira". Guedes (2008, p. 40) afirma que, no período onde o neoliberalismo esteve no auge, "o mobbing estratégico foi largamente 
utilizado por empresas e instituições financeiras para eliminar do quadro os empregados considerados inadequados para o novo modelo de produção flexível inaugurado".

Outra diferença entre o assédio interpessoal e o organizacional é o alvo. No primeiro caso, a vítima, normalmente, é um único indivíduo que sofre perseguição de outro ou de um pequeno grupo. Dificilmente mais de uma pessoa é vítima de um mesmo caso de assédio moral e, quando isso ocorre, é um pequeno grupo.

No caso do assédio organizacional, dá-se o oposto e o alvo costuma ser um grupo grande da empresa ou um setor específico. Depende muito dos objetivos empresariais. $\mathrm{O}$ estabelecimento de metas abusivas que demandem um desgaste maior do que o razoável ou aceitável pelo direito atinge a quase totalidade dos empregados. Se a gestão por estresse se der contra beneficiários de algum tipo de estabilidade legal (gestante, acidentados, cipistas etc.) o alvo é um grupo determinável. Este é o caso também quando o alvo das agressões são os empregados da empresa adquirida por uma maior, principalmente quando se trata de uma empresa pública absorvida por uma privada.

O reconhecimento do dano moral coletivo propiciou o análogo reconhecimento de assédio moral coletivo ou organizacional. Neste caso, a intervenção do sindicato da categoria torna-se mais importante, pela via negocial, pela pressão sindical não excluindo a possibilidade de greve ou com o ingresso de ação coletiva na Justiça do Trabalho. Até mesmo a intervenção do Ministério Público do Trabalho com o ingresso de ação civil pública ou por celebração de Termo de Ajustamento de Conduta é viável aqui.

O assédio moral organizacional figura, no rol dos direitos coletivos, como causador de um dano causado a interesses individuais homogêneos. Tal fundamento explica-se pelo caráter personalíssimo dos direitos lesados pelo assédio, como a integridade física, psíquica, moral, social. O que ocorre é o prejuízo a um feixe de vítimas envolvidas, onde a personalidade de todos é igualmente atingida; mas esta personalidade é, como o próprio nome sugere, individualíssima.

Disso decorre que a reparação pode ser pleiteada judicialmente individual ou coletivamente. O grupo assediado poderá ingressar em juízo em conjunto porque o interesse tem origem comum: a agressão é a mesma, o agressor é o mesmo e a lesão causada também.

Questão de difícil viabilidade é acerca da possibilidade de ocorrência de assédio organizacional na fase pré-contratual. Há empresas que focam em candidatos com o “corpo-máquina” em estado de saúde beirando a perfeição, no que em muito se assemelha 
a processos de eugenia. A possibilidade de se constatar uma espécie de higienismo e discriminação é real.

Margarida Barreto trás alguns relatos em suas pesquisas que auxiliam o debate. Cita casos de empresas onde o setor de recursos humanos, responsável pelas contratações, requerem uma bateria de exames incompatíveis com o ordenamento jurídico pátrio.

Realizam raio X, de tórax e coluna, ultra-som, eletroneuromiografias (ENMG), eletroencefalogramas (EEG), eletrocardiograma tonal (ECG), dinamometrias, audiometrias e impedanciometrias, visiontest, múltiplas análises de sangue e urina, provas de função pulmonar, citologia oncótica (mulheres), PSA (homens), exame odontológico, pesquisa de HIV e beta HCG (BARRETO, 2006, p. 122).

Há situações expressamente resolvidas pela lei como a proibição de exame de HIV por exemplo. Mas até que ponto pode se chegar na avaliação dos candidatos sem ultrapassar o juridicamente aceitável? Uma empresa que exige foto para a contratação de uma recepcionista não o faz acintosamente com o escopo de discriminar pela aparência física?

As entrevistas de seleção, normalmente realizadas por profissionais de psicologia, fazem uma bateria de indagações que invadem a intimidade e a privacidade dos candidatos. Perguntam se bebem, se fumam, quantos filhos têm, quais os hobbies, o que ouvem, o que lêem, que lugares freqüentam, orientação sexual dentre outras.

O problema nesses casos é que é mais fácil comprovar o dano moral, mas é inviável qualificá-lo como assédio pela curta duração inerente à fase de seleção. De toda sorte, essas seleções ilustram que as práticas de agressão moral podem ser políticas de gestão das organizações sem visar um alvo específico.

De outro lado, é mais viável perceber casos de assédio organizacional quando da ruptura do contrato. Os exemplos citados de empresas que humilham abertamente empregados com estabilidade, mormente previdenciária, encaixam-se perfeitamente nessa modalidade. Os trabalhadores pedem dispensa após longo processo de agressão moral, exposição pessoal, constrangimento com o intuito de forçar-lhes a abdicar da estabilidade e pedir desligamento.

Perseguições a empregados oriundos de empresas públicas compradas por outras privadas também denotam assédio moral organizacional na extinção da relação de emprego. O grupo de empregados outrora servidores, que gozavam de estabilidade, torna- 
se alvo freqüentemente da empresa adquirente. São discriminados todo o tempo até que não suportam mais a humilhação e pedem para sair.

O assédio moral organizacional significa, na prática, o abuso do poder diretivo por parte do empregador. O Direito do Trabalho confere a este a prerrogativa de selecionar quem quiser para atuar entre seus quadros, atribuir tarefas que lhe convierem com a conseqüente fiscalização e punibilidade, o poder potestativo de dispensar quem quiser etc. Mas toda essa relação entre o capital e o trabalho, é mediada pelo Direito do Trabalho e pelo contrato de emprego.

A relação fática que se estabelece de absorção da força de trabalho no processo de produção e reprodução capitalista é o conteúdo e o contrato individual de emprego celebrado é a forma desta relação. Há uma tensão entre o processo econômico da estrutura produtiva e as condicionantes impostas pela superestrutura estatal. O Direito do Trabalho estabelece uma normalidade que é generalizada para todas as relações de assalariamento.

Embora os juristas em geral não admitam, a economia molda o direito de modo que lhe garanta estabilidade e impeça uma ruptura, uma vez que o processo produtivo é anárquico e, se deixá-lo por conta própria, tende à sua própria destruição. $\mathrm{O}$ assédio moral organizacional é explicado por isso.

A legislação confere ao empregador o poder diretivo sobre o empregado conforme já observado. Só que esse poder não é absoluto nem ilimitado: limitam-lhe as leis e os contratos individuais ou coletivos. Exceder esse limite configura abuso do poder; no caso, abuso do poder diretivo.

É legalmente possível ao empregador estabelecer metas a serem cumpridas aos empregados e fiscalizar o cumprimento destas. A partir das metas, organiza-se a atuação empresarial e avalia-se o desempenho individual e coletivo dos trabalhadores. Mas essas metas encontram limites expressos pelo direito.

Tais limites, se excedidos, configuram abuso do poder diretivo traduzido na figura do assédio organizacional. Há limites absolutos que são expressos e limites relativos que devem ser apurados em cada caso. Exemplo de limites expressos é o temporal: segundo o art. $7^{\circ}$, XIII da Constituição Federal, a jornada não pode exceder as $8 \mathrm{~h}$ diárias e 44 semanais em nível geral. Mas há categorias com outras jornadas, como 6h para bancários, telefonistas e mineiros, $5 \mathrm{~h}$ para médicos e jornalistas.

A título de exemplo, uma empresa de call-center pode estabelecer que cada atendente tenha que realizar um número $\mathrm{x}$ de atendimentos por dia, desde que esse número 
x seja possível de ser realizado dentro de um espaço de tempo de seis horas. Supondo que x seja o número razoável, no plano ideal, de atendimentos diários, a empresa que exigir 2x estará incidindo em assédio moral organizacional, porque abusa do direito de dirigir a prestação dos serviços, agride direitos personalíssimos dos empregados como método de aumento de produtividade e redução de custos.

Outra limitação expressa é o salário mínimo, seja esse o geral, o profissional ou o da categoria. A Constituição garante no art. $7^{\circ}$, VII, "garantia de salário, nunca inferior ao mínimo, para os que percebem remuneração variável”. O abuso do poder, nesse caso, tem como conseqüência a ruptura contratual como prevista no art. 483, g da CLT.

Mas também há limites não expressos de forma quantificada por serem qualitativos, personalíssimos, e que devem ser apurados com mais acuidade. Como definir que um empregado teve a sua dignidade lesada? Não há uma definição prévia do que é e do que não é digno, os valores devem ser apurados no bojo do processo.

Tomem-se os exemplos da revolução industrial na Inglaterra. Os trabalhadores passavam dezesseis horas na fábrica, não paravam nem para almoçar, crianças de seis ou sete anos já laboravam, dormiam dezenas de peões no mesmo quarto, as condições de higiene e segurança eram as piores, os salários não eram suficientes nem para custear o mínimo de alimentação exigido para a manutenção dos indivíduos. Aos 30, as pessoas já eram anciãs.

Nessas condições, é óbvia a constatação de que a dignidade dos trabalhadores estava totalmente desrespeitada. Mas é possível trazer exemplos mais atuais noticiados cotidianamente ainda hoje no Brasil. Grandes fazendas que mantém seus trabalhadores em condições análogas à de escravo, indústrias têxteis onde bolivianos trabalham doze horas por dia, empreiteiras que levam empregados da construção civil para o interior e organiza alojamentos em péssimas condições.

Esses são exemplos onde o poder diretivo do empregador é extrapolado e este incorre em abuso porque utiliza suas prerrogativas legais em desacordo com as finalidades a que o Direito lhes impõem. Em outras palavras, praticam atos de agressão moral constantes e reiterados para atingir objetivos empresariais como redução de custos da mãode-obra e aumento da produtividade, ocasionando danos à saúde física e psíquica dos empregados à direitos personalíssimos destes. Em outras palavras mais, incorrem em assédio moral organizacional, onde o assédio faz parte da política de gestão de recursos humanos da empresa. 
A definição de assédio moral de Maurício Godinho Delgado aponta nesta direção.

Do mesmo modo, o chamado assédio moral, que consiste na exacerbação desarrazoada e desproporcional do poder diretivo, fiscalizatório ou disciplinar pelo empregador de modo a produzir injusta e intensa pressão sobre o empregado, ferindo-lhe o respeito e a dignidade (DELGADO, 2007, p. 1214).

As metas de gestão e os sistemas de avaliação podem ser atribuídas ao poder diretivo enquanto constituírem mecanismos de organização do trabalho, mas não podem significar a degradação moral dos empregados. Se por um lado a empresa dirige a prestação do serviço, por outro ela assume os riscos do negócio, o que é conhecido como alteridade. Uma vez que a empresa fica com os bônus do negócio (lucros), deve arcar com os ônus.

Os estudos sobre economia do trabalho relativos ao capital humano parecem ter a intenção de romper com a alteridade e jogar nos ombros dos trabalhadores a responsabilidade pelos negócios. Elaboram cálculos tão precisos sobre o agir do trabalho, a produtividade individual e coletiva, os instrumentos de avaliação que transferem aos empregados toda a responsabilidade pelo sucesso da empresa. Se estes cumprem seu dever conforme o ordenado, a organização vai bem.

A jurisprudência trabalhista já reconhece o assédio moral organizacional, como no acórdão abaixo extraído do TRT da $16^{\text {a }}$ Região.

\footnotetext{
ASSÉDIO MORAL ORGANIZACIONAL. GESTÃO POR ESTRESSE. STRAINING. PRÁTICA CONSISTENTE NO INCENTIVO AOS EMPREGADOS DE ELEVAREM SUA PRODUTIVIDADE, POR MEIO DE MÉTODOS CONDENÁVEIS, COMO AMEAÇAS DE HUMILHAÇÕES E RIDICULARIZAÇÕES. DEVIDA INDENIZAÇÃO POR DANOS MORAIS COLETIVOS. REDUÇÃO DO QUANTUM FIXADO PELA INSTÂNCIA A QUO. A gestão por estresse, também conhecida como assédio moral organizacional ou straining consiste em uma "técnica gerencial" por meio da qual os empregados são levados ao limite de sua produtividade em razão de ameaças que vão desde a humilhação e ridicularização em público até a demissão, sendo consideravelmente mais grave que o assédio moral interpessoal (tradicional) por se tratar de uma prática institucionalizada pela empresa, no sentido de incrementar seus lucros às custas da dignidade humana dos trabalhadores. Caracterizada tal situação, é devida indenização pelo dano moral coletivo causado, que deve ser suficiente, sobretudo, para punir a conduta (função punitiva) e para desincentivar os infratores (função pedagógica específica) e a sociedade (função pedagógica genérica) a incorrerem em tal prática, mas também para proporcionar, na medida
} 
do possível, a reparação dos bens lesados, como preceitua o art. 13 da Lei 7.347/85. Assim, tendo em vista a amplitude das lesões e suas repercussões, razoável a redução do quantum indenizatório para $\mathrm{R} \$$ 200.000,00 (duzentos mil reais). Recurso ordinário do Sr. Alessandro Martins não admitido, por deserto. Recurso ordinário da Euromar conhecido e, no mérito, parcialmente provido.137.347 (772200801616005 MA 00772-2008-016-16-00-5, Relator: JOSÉ EVANDRO DE SOUZA, Data de Julgamento: 13/04/2011, Data de Publicação: 26/04/2011).

O assédio organizacional é descrito a prática de aumentar a produtividade por meios de métodos condenáveis que atentam contra a dignidade humana. O acórdão reconhece a existência de um dano moral coletivo e afirma que tais práticas são mais graves que o assédio interpessoal por serem incorporadas à gestão da empresa. Pensamento semelhante fundamenta o seguinte acórdão proferido pelo TRT da $9^{a}$ Região.

TRT-PR-27-08-2010 EMENTA: COBRANÇA DE METAS. AGRESSÃO VERBAL DO SUPERIOR HIERÁRQUICO. ASSÉDIO MORAL ORGANIZACIONAL. A dignidade da pessoa humana, fundamento de nosso Estado Democrático de Direito (art. $1^{\circ}$, III, CF), deve prevalecer no cotejo com o poder diretivo do empregador. Isso porque a ordem econômica é fundada na valorização do trabalho humano (art. 170, CF), não se podendo admitir o exercício da livre iniciativa em detrimento de direitos da personalidade do trabalhador. O despreparo emocional da supervisora, ao cobrar metas aos gritos de sua equipe e acusar os trabalhadores de serem lentos, afeta negativamente o ambiente de trabalho, configurando prática de assédio moral organizacional. (19700200829906 PR 19700-2008-29-9-0-6, Relator: LUIZ CELSO NAPP, 4A. TURMA, Data de Publicação: 27/08/2010).

A turma julgadora preocupou-se em afirmar que a dignidade da pessoa humana limita o poder diretivo do empregador. Se este direito fere aquele, configura-se abuso de poder.

Há acórdãos em que o órgão julgador não denominou expressamente o assédio enquanto organizacional, mas o reconheceu, como no exemplo abaixo extraído do TST. 

PERSONALIDADE CONSTITUCIONALMENTE PROTEGIDOS -
DECISÃO REGIONAL PROFERIDA À LUZ DO ART. 5 $5^{\circ}$ X, DA
CONSTITUIÇÃO FEDERAL. 1 . Conforme estabelece o art. $5^{\circ}, \mathrm{X}$, da CF, o dano moral passível de indenização diz respeito à violação da imagem, honra, vida privada e intimidade da pessoa. 2. Na hipótese dos autos, o Regional consignou que o Reclamado, com o intuito de controlar as suas metas de produção, adotava para seus empregados condutas claramente constrangedoras. Nesse contexto, registrou o TRT que a Empresa restringia a ida de seus funcionários ao sanitário a apenas duas ou três vezes ao dia, com duração de cinco minutos cada uma delas, e com a sujeição, em algumas ocasiões, a autorização do superior hierárquico, o qual poderia, inclusive, ir buscar o funcionário que demorasse mais do que cinco minutos no sanitário, havendo, ainda, determinação para que o empregado que fosse ao toalete deixasse seu crachá pendurado nas vassouras. Por outro lado, as saídas para beber água também eram controladas. Ademais, havia no Reclamado diretriz, constante do seu regulamento, para a medição da produtividade, sendo utilizado para tanto um cronômetro, que calculava o tempo de trabalho dos funcionários quando a produtividade não era satisfatória, ocasião em que algum funcionário do Reclamado, com o aparelho na mão, se posicionava na frente do empregado cujo tempo de trabalho estava sendo contado, o que causava bastante nervosismo em alguns deles. Por fim, quando as metas de produção não eram alcançadas, havia muita pressão por parte do Reclamado, que cobrava dos empregados o seu alcance sob pena de terem que trabalhar além do normal ao longo da jornada. 3 . Assim, concluiu o Regional que havia nos autos farto conjunto fático-probatório caracterizando o assédio moral e o terror psicológico vivenciados pelos Obreiros no ambiente de trabalho, o que lhes causava verdadeira angústia quanto à manutenção de seus empregos e ao sustento de suas famílias. 4. Neste contexto fático e à luz do que estabelece o art. $5^{\circ}, \mathrm{X}$, da $\mathrm{CF}$, segundo o qual são invioláveis a intimidade, a vida privada, a honra e a imagem das pessoas, assegurado o direito a indenização pelo dano material ou moral decorrente de sua violação, revela-se acertada a conclusão a que chegou a Corte de origem, pois, independentemente dos motivos que justificariam o zelo pela produtividade, o Reclamado deveria observar critérios de razoabilidade, devendo o Empregador, que é responsável direto pela qualidade das relações e do ambiente de trabalho, adotar medidas compatíveis com os direitos da personalidade constitucionalmente protegidos. RR - 1186/2007-004-20-00. $7^{\text {a }}$ TURMA DO TST. MINISTRO RELATOR: IVES GANDRA MARTINS FILHO. PUBLICAÇÃO: 15/05/2009.

Embora o TST não utiliza aqui a expressão assédio organizacional, reconhece a prática atentatória à dignidade obreira e motivo de reparação. Afirma que as medidas usadas para o atingimento de metas eram incompatíveis com os direitos fundamentais. $\mathrm{O}$ TST utiliza inclusiva a expressão terror psicológico para qualificar os absurdos métodos de gestão descritos.

Conceituado o assédio moral organizacional, torna-se necessário analisar os fundamentos jurídicos violados quando de sua ocorrência. 
É recorrente a afirmação de que o assédio moral lesa a dignidade, a personalidade e a saúde dos trabalhadores. Esses são os três valores normativos centrais cujo desrespeito é a fundamentação jurídica do assédio moral em geral e do assédio organizacional em particular. Os três são analisados a partir de então.

2.7.1 A dignidade da pessoa humana

A dignidade é comumente considerada como o direito mais fundamental de um ordenamento jurídico que se repute democrático. Há juristas que defendem incisivamente que a ausência da proteção jurídico-constitucional da dignidade denota ausência do Estado democrático de direito em si.

De plano, refuta-se aqui a tese, defendido por um sem número de estudiosos, que afirmam ser a dignidade como um direito universal e atemporal aos moldes das teorias jusnaturalistas. Não que este trabalho se afilie aos positivistas que crêem que só há proteção dos direitos humanos a partir da positivação destes. A questão é que, ao deslocar o conceito para uma abstração tal que se repute o direito a todo e qualquer ser humano em qualquer lugar e qualquer época, está-se deslocando a realidade do direito e suas nuances, sua evolução histórica que flutua em acordo com as contradições das sociedades. Em síntese: está-se colocando o direito à dignidade para além da luta de classes, o que não é admitido neste trabalho.

A Declaração Universal dos Direitos proposto pela ONU em 1948, em seu primeiro artigo, prevê que "art. $1^{\circ}$. Todos os seres humanos nascem livres e iguais em dignidade e direitos. Dotados de razão e consciência, devem agir uns para com os outros em espírito de fraternidade". A previsão da dignidade logo no primeiro artigo concorda com os argumentos trazidos por aqueles que defendem que este é o direito mais fundamental, mais central, mais importante de um ordenamento jurídico democrático.

O texto deste artigo revela forte influência dos valores emanados pela revolução francesa, ao citar expressamente a liberdade, a igualdade e a fraternidade. Percebe-se ainda 
que o conceito de dignidade aqui adotado, como é hegemônico senão absoluto atualmente, é o kantiano, o que será desenvolvido mais à frente.

Seguindo esta mesma linha, a Constituição Federal de 1988 aponta também no seu primeiro artigo a dignidade da pessoa humana como um dos fundamentos da República Federativa do Brasil, art. $1^{\circ}$, III, ao lado da soberania (inc. I), cidadania (inc. II), valores sociais do trabalho e da livre iniciativa (inc. IV) e pluralismo político (inc. V).

A dignidade volta a aparecer mais a frente na Constituição como fundamento da ordem econômica: "art. 170. A ordem econômica, fundada na valorização do trabalho humano e da livre iniciativa, tem por fim assegurar a todos existência digna, conforme os ditames da justiça social, observados os seguintes princípios (...)”.

Pode-se interpretar destes dois comandos constitucionais que a república será organizada em torno do modo de produção capitalista, com a apropriação privada do trabalho coletivo. Mas o exercício deste funcionar econômico é limitado pela dignidade da pessoa humana, que deverá ser observada mesmo no trabalho subordinado.

Antes de adentrar no significado destes comandos, é preciso analisar o desenvolvimento histórico dos direitos humanos para se ter em mente como chegou-se até aqui. Essa análise envolve a compreensão das três principais gerações de direitos, que envolvem a liberdade, a igualdade e a fraternidade. Estes estão imbricados com o desenvolvimento do capitalismo e suas contradições.

A primeira geração de direitos humanos são os chamados direitos de liberdade, ou direitos individuais, ou de prestação negativa. O surgimento da classe burguesa na Europa entrava em confronto com o sistema feudal vigente e sua aristocracia baseada em privilégios. Situa-se na Magna Carta de 1215 na Inglaterra o primeiro documento legal que garantia tais direitos, com a previsão de só privar um cidadão de sua liberdade ou de seus bens após um julgamento justo.

A Declaração dos Direitos do Bom Povo da Virgínia de 1776 e a Constituição americana de 1787, extremamente individualistas, iam na mesma direção.Com a revolução francesa e a Declaração dos Direitos do Homem e do Cidadão de 1787, os direitos humanos adquiriram ares de universalidade.

Nessa primeira, foram garantidos os direitos individuais à vida, à liberdade, à propriedade, a um julgamento justo dente outros. A aristocracia e nobreza feudais anteriores eram baseados na autoridade total da monarquia. O rei era dono de tudo e de todos e podia agir como se tudo fosse sua propriedade, podendo confiscar bens e 
patrimônios de quem quisesse sem motivo algum ou ordenar uma prisão por mera liberalidade.

Para que o modo capitalista de produção se assentasse e superasse em definitivo o modo feudal, tais privilégios que emanavam do Estado tinham que ser tolhidos. O capitalismo pressupõe a livre circulação de mercadorias, a liberdade de contratar, de comprar e vender, inclusive a força de trabalho alheia. O reino da propriedade individual era incompatível com o absolutismo estatal. Por isso diz-se que esses direitos individuais são negativos, porque exige uma abstenção da prática de força do Estado para com os particulares. O Estado deveria respeitar o indivíduo e suas liberdades e direitos, mormente o de propriedade.

Essa primeira geração de direitos dizia respeito a uma classe específica, a burguesa, proprietária, que se tornou dominante. E mais: como as mulheres não tinham cidadania, esses direitos só se aplicavam aos homens. A declaração era dos direitos do homem e do cidadão, e não da mulher e da cidadã.

O estabelecimento do modo de produção capitalista como dominantes e a revolução industrial permitiram o acúmulo do capital em novas bases, mas também gerou o seu duplo negativo: o trabalho assalariado. Este foi denominado "livre" porque era baseado em um contrato. É bom que se diga que liberdade, para a classe dominante, era liberdade contra o Estado e não contra o mercado.

A classe trabalhadora assalariada não gozava de tais liberdades justamente porque não tinha propriedade nenhuma. A expressão "proletariado" indica que a única propriedade que tinham era uma "prole" numerosa. Alguém já disse que entre o forte e o fraco, quem oprime é a liberdade. A liberdade, que nada mais era que uma liberdade de mercado, evidenciou as diferenças entre os proprietários dos meios de produção e os proprietários da força de trabalho.

Trabalhava-se por até 16 horas diárias nas fábricas, comendo mal, dormindo pior, sofrendo acidentes e tornando-se inválidos, morava-se a léguas de distância do trabalho, não havia aposentadoria ou proteção para os doentes, o salário era insuficiente para o alimento próprio e do da família. E o pior: os trabalhadores não podiam se organizar e lutar coletivamente porque o individualismo burguês considerava o sindicalismo como um atentado às liberdades individuais.

Da mesma forma que a aristocracia do regime antigo opôs-se à primeira geração de direitos humanos, a burguesia opôs-se à segunda geração, a dos direitos sociais, ou 
positivos, ou de (uma pretensa) igualdade. Esta segunda geração de direitos humanos exigia não uma abstenção, mas uma prestação por parte do Estado. Este foi convocado a intervir no mercado de forma a atenuar as desigualdades.

É na segunda geração de direitos humanos que surgem a previdência, os sistemas de aposentadoria, o salário mínimo, a limitação do trabalho de crianças e mulheres, as normas de insalubridade, o reconhecimento legal dos sindicatos e o direito de greve. Tais direitos só foram possíveis pela luta coletiva dos trabalhadores, o que só foi permitido com a ruptura com o individualismo burguês e a possibilidade de associação sindical. A segunda geração de direitos humanos representa os direitos dos trabalhadores.

A partir do momento em que o capitalismo se impõe como sistema de produção dominante e os direitos individuais (da burguesia) e sociais (dos trabalhadores) representam a apreensão jurídica desse sistema econômico, surgiram os direitos humanos de terceira geração ou difusos. Se a primeira geração garantiu a liberdade e a segunda, a igualdade, a terceira viria a garantir a fraternidade com os direitos do consumidor, os direitos ao meio ambiente, à paz, à comunicação dentre outros.

Pode-se dizer que os direitos humanos de primeira geração asseguraram o capitalismo enquanto modo de produção e a burguesia enquanto classe dominante. Os de segunda geração garantiram um mínimo de dignidade aos assalariados de forma que não se desestabilizasse o sistema econômico e asseguraram os trabalhadores enquanto classe dominada; esta pode ter um milhão de direitos, desde que se mantenha intocada a propriedade e a apropriação privada do trabalho alheio. Os direitos de terceira geração se propõem a serem direitos não de uma classe, mas de todas as pessoas que viveriam na mais tenra fraternidade dentro do modo de produção capitalista.

Não se pretende aqui aprofundar no debate sobre estes direitos ou sobre uma suposta quarta geração de direitos humanos. O importante é constatar que os direitos humanos compõem uma totalidade jurídica que visa garantir a dignidade humana.

É necessário conceber as liberdades públicas como aqueles direitos que possibilitam ao indivíduo - isolada ou socialmente considerado - o seu pleno desenvolvimento, tomando-se por base a dignidade da pessoa humana, bem como a igualdade e a justiça (SIMÓN, 2000, p. 52). 
Esses direitos humanos garantidores da dignidade vivenciaram um período de normatização jurídico-constitucional que lhes assegurava a proteção estatal e a sua observância mesmo entre particulares. Sandra Lia Simón cita Canotilho para afirmar que estes direitos adquirem um aspecto de fundamentalidade formal e material.

$\mathrm{O}$ aspecto formal da fundamentalidade dos direitos humanos significa que estas normas estão em um patamar superior do ordenamento jurídico, seu processo de revisão pelo parlamento é mais rigoroso, servem como limites à revisão constitucional e vinculam os poderes públicos em suas atuações. $\mathrm{O}$ aspecto material indica que constituem a estrutura do Estado, permitindo que a Constituição esteja aberta ao surgimento de novos direitos humanos, assegure aqueles não previstos expressamente e se aplique a fundamentalidade formal.

Enquanto os direitos humanos estão no plano das declarações internacionais como meta a serem atingidas pelos povos, são chamados de direitos humanos. No momento em que se tornam juridicamente constitucionalizados, passam à denominação de direitos e garantias fundamentais, tal qual se encontra na Constituição Federal de 1988. Os direitos fundamentais visam então à garantia da dignidade humana.

Retornando aos arts. $1^{\circ}$ e $170^{\circ}$ da Constituição de 1988, tem-se que a República Federativa do Brasil tem fundamento na soberania, cidadania, dignidade da pessoa humana, valor social do trabalho e livre iniciativa, e pluralismo político e que a ordem econômica visa garantir a todos a dignidade. Percebe-se por estes comandos que os direitos fundamentais foram assegurados para estabelecer a dignidade e que esta resolverá a tensão das relações entre capital e trabalho, representando os limites da exploração do trabalho alheio. Os valores sociais do trabalho e da livre iniciativa estão juntos no art. $1^{\circ}$, III porque os direitos de segunda geração limitaram os de primeira geração. Mas em que consiste, de fato, a dignidade da pessoa humana?

Para responder essa pergunta, é preciso analisar o desenvolvimento histórico do conceito partindo da idade antiga até chegar a Kant, com quem a dignidade adquiriu uma definição utilizada até hoje. Ingo Wolfgang Sarlet apresenta um interessante roteiro que será utilizado como base.

Na Roma antiga, a dignidade tinha um duplo conceito: por um lado, o homem está em uma posição especial na natureza em virtude de sua racionalidade e, por outro, o indivíduo encontra-se em uma posição social que também lhe confere dignidade. Ao 
vincular a dignidade à posição social do indivíduo, permite-se quantificar a dignidade e afirmar que uma pessoa pode ter mais dignidade do que outra.

Esta distinção pela posição hierárquica na sociedade era negada na Grécia pelos estóicos que afirmavam que todas as pessoas são iguais em dignidade por serem os humanos distintos dos animais. A dignidade estava então ligada à liberdade pessoal, pois todos seriam responsáveis por seus atos e seus destinos.

A dupla noção de dignidade que imperava na antiguidade, particularmente entre os romanos, encontrava explicação nas bases econômicas escravistas da economia. Se a classe trabalhadora era escrava, desprovida de personalidade e subjetividade porque era mercadoria, propriedade alheia, não havia como igualar em dignidade os escravos dos seus donos.

O pensamento cristão, que atingiu seu auge de dominação e influência no período medieval, fundamentou a idéia de dignidade no fato de que Deus fez o homem à sua imagem e semelhança e, ao fazê-lo, dignificou a natureza humana. Com este fundamento, todas as pessoas teriam liberdade para realizar suas vontades e construir livremente os seus destinos com autodeterminação e racionalidade.

Com a renascença e o humanismo crescentes na sociedade européia, quando a ruptura da modernidade contra a medievalidade estava em curso, surgiu a necessidade de romper com a idéia de que a dignidade era uma concessão divina e trazê-la para o mundo secular. Se a Igreja Católica era um dos pilares de dominação ideológica do regime antigo, sua superação era premente.

Primeiro, fundamentou-se em uma liberdade moral a capacidade do homem definir seu destino e tomar suas decisões em acordo às suas vontades. Depois, o fundamento da dignidade passou a ser a racionalidade humana, completando a secularização da dignidade.

Kant sinala que a autonomia da vontade, entendida como a faculdade de determinar a si mesmo e agir em conformidade com a representação de certas leis, é um atributo apenas encontrado nos seres racionais, constituindo-se no fundamento da dignidade da natureza humana (SARLET, 2010, p. 37).

A partir da noção da racionalidade humana, Kant afirma que o homem é um fim em si mesmo e não poderia ser utilizado como meio para satisfazer as vontades de outrem. Os seres que não dispõem de tal racionalidade são coisas e os racionais são pessoas que tem 
autonomia para determinar suas ações. Se uma coisa tem um preço, outra poderia ser colocada em seu lugar; mas aquilo que tem dignidade está acima de todo preço e não pode ser meio para satisfações de vontades alheias.

A dignidade humana, o valor humano, teria um certo caráter normativo, não podendo ser utilitário. Segundo Sarlet é na conceituação proposta por Immanuel Kant que o Direito encontra a fundamentação e conceituação e da dignidade enquanto autonomia e determinação do seu destino. A partir desta definição, Sarlet (2010, p. 42) afirma que, na concepção kantiana, "a dignidade da pessoa humana, esta (pessoa) considerada como fim, e não como meio, repudia toda e qualquer espécie de coisificação e instrumentalização do ser humano".

Sendo a dignidade um limite à exploração do trabalho alheio e considerando a relação entre empregador e empregado, onde este vende àquele a sua força de trabalho em troca de salário para que o empregador se utilize deste trabalho visando obter seus fins, como poderia a dignidade limitar essa relação que, em si, é uma coisificação? Reformulando a pergunta: se o poder diretivo garante ao empregador organizar a prestação do serviço do empregado junto aos demais fatores da produção, como poderia a dignidade intervir aqui?

A resposta não é fácil e é necessariamente submetida a relativizações. Ingo Wolfgang Sarlet (2010, p. 59) ressalva que Kant nunca negou a possibilidade de instrumentalização de uma pessoa "de tal sorte que venha a servir, espontaneamente e sem que com isto venha a ser degradado na sua condição humana, à realização de fins de terceiros, como ocorre, de certo modo, como aquele que presta um serviço a outro". Ou seja, a dignidade é incompatível com a instrumentalização da pessoa, mas não é incompatível com a instrumentalização do trabalho assalariado!

Thereza Cristina Gosdal também percebe o problema e busca uma resolução no mesmo sentido. Para ela, considerar a apropriação do trabalho pelo capital seria um critério muito amplo para delimitar "o que numa relação de trabalho desenvolvida sob o capitalismo, como ocorre com a realidade pátria atual, pode ser considerado como atentatório da dignidade do trabalhador (GOSDAL, 2007, p. 84).

O problema central aqui é que o conceito de dignidade sempre esteve vinculado à visão de mundo das classes dominantes e só é, de fato, assegurada a elas. A idéia de autodeterminação, de realização de suas vontades e construção de seu destino é aplicável ao empreendedorismo, à livre iniciativa. Mas a idéia de que ninguém pode ser 
instrumentalizado para os interesses de outrem é incompatível com a apropriação do trabalho alheio. Todos os empregados são instrumentalizados pelas empresas.

Não é coincidência que a definição de dignidade da pessoa humana aplicada até hoje tenha sido criada em paralelo aos direitos humanos de primeira geração. Kant era um ardoroso defensor da revolução francesa e sua filosofia estava conectada com os interesses ideológicos da burguesia revolucionária.

Por isso, pregam-se ideologias de que o trabalho dignifica o homem e pelo trabalho os indivíduos se realizam e interagem com a sociedade. A ética protestante, essa religião da revolução burguesa, veio a dignificar o trabalho e o acúmulo de riquezas como expôs Max Weber.

O trabalho assalariado é chamado de livre no bojo desse problema. Diz-se que a sujeição do escravo e do servo era pessoal e que o poder diretivo é exercido sobre a prestação do serviço e não sobre a pessoa do assalariado. Este seria livre para contratar com quem quisesse, o que não é verdade porque o empregado não está livre das leis do mercado.

Mas, retornando ao problema no seio de um ordenamento constitucional que tem a exploração capitalista como digna, Sarlet sugere que o critério definidor da dignidade como limite da relação entre empregado e empregador seria o objetivo da conduta, a intenção de coisificar o outro. Gosdal sugere que seria o abuso do poder diretivo, quando este poder é utilizado em desacordo com a sua finalidade social.

Utilizando-se dessas definições de objetivo (Sarlet) e abuso de poder (Gosdal), com as ressalvas já propostas, resgate-se os objetivos de um processo de assédio moral organizacional: "Pretende-se alcançar, ou manter, determinados objetivos empresariais ou institucionais relativos a índices de produtividade e/ou atingimento de resultados, ao controle dos trabalhadores e aos custos do trabalho" (GOSDAL, SOBOLL, 2009, p. 40).

Pode-se concluir então que o assédio moral organizacional atenta contra a dignidade da pessoa humana na medida em que há um objetivo manifesto de atingir os objetivos traçados pela empresa no sentido de atingir índices de produtividade, metas e resultados, abusando a empresa do seu poder diretivo na medida em que coisifica, instrumentaliza os empregados com o escopo de alcançar seus fins.

O acórdão do TST condena o uso de prendas e castigos como mecanismos de aumento da produtividade por ferirem a dignidade da pessoa humana. $\mathrm{O}$ trabalho assalariado não é considerado indigno a priori, mas o é quando há uma extrapolação do 
poder diretivo em relação á sua finalidade socialmente concedida. Os trabalhadores não podem assumir um caráter utilitário para o atingimento de objetivos empresariais que os trate como coisas, entendidas essas como desprovidas de dignidade, com valor quantificável.

Enquanto o empregado presta um serviço em troca de um salário em condições estáveis, o ordenamento jurídico assegura a manutenção da relação e a estabilidade do sistema. Mas se a empresa empregadora instrumentaliza seus empregados para o atingimento de seus objetivos relativos à produtividade e ao cumprimento de metas de forma a transferir os riscos de negócio aos trabalhadores em detrimento da saúde destes, extrapola o uso razoável do poder diretivo na medida que quantifica os valores dos obreiros, retira-lhes a personalidade e atribui-lhes instrumentalidade. Coisifica-os. Atentam contra a dignidade da pessoa humana.

Este é o limite direto imposto pela dignidade da pessoa humana ao poder diretivo, de forma a configurar o assédio moral organizacional. Mas há outras fundamentações, na medida em que os direitos e garantias fundamentais delimitam os direitos de personalidade, absorvidos pelo direito civil e, posteriormente, pelo direito do trabalho.

2.7.2 Os direitos da personalidade

Para a teoria clássica do Direito, a pessoa é o ente físico ou jurídico capaz de atrair para si a incidência de direitos e obrigações. É o sujeito ativou ou passivo de uma relação jurídica, titular de um direito ou de uma obrigação, apto a figurar num dos pólos de uma ação perante o judiciário, reivindicando o cumprimento ou sendo o alvo de uma reivindicação de um direito.

A personalidade é, então, essa capacidade de adquirir direitos e obrigações. Esta não se confunde com os direitos, mas é um pré-requisito para obtê-los porque todo direito está relacionado a uma pessoa; só adquire direitos quem tem personalidade jurídica.

É de conhecimento amplo que a expressão persona surgiu com o teatro na idade antiga, sendo esta a máscara que os autores utilizavam para aumentar o volume da voz e fazê-la ecoar (per sonare) mais facilmente ao público. A expressão passou a ser usada 
depois para designar o papel que o ator desempenhava e, por fim, passou a identificar o próprio ator.

Da mesma forma como a persona era o instrumento pelo qual o indivíduo adentrava no mundo teatral, a personalidade é a forma como o ser humano adentra no mundo jurídico. Dito de outro modo, ao ser humano do mundo natural corresponde à pessoa do mundo jurídico.

Atualmente é reconhecida a personalidade, ou seja, a possibilidade de adquirir direitos e obrigações, de atuar em uma relação jurídica, a entes não humanos denominados pessoa jurídica justamente por serem uma ficção criada pelo direito. Uma empresa, uma associação, uma fundação, um ente estatal têm personalidade jurídica.

Inicialmente, os direitos incidiam preferencialmente sobre a propriedade. As pessoas contraíam direitos e obrigações de natureza econômica, auferíveis pecuniariamente. O conjunto das relações jurídicas individualizadas denominou-se patrimônio, sendo este a projeção econômica da personalidade e objeto primeiro do direito.

Os direitos da personalidade só vieram a surgir com o advento do capitalismo e seu estabelecimento enquanto modo de produção dominante. A positivação dos direitos individuais desde a Carta Magna inglesa e a conseqüente efetivação dos direitos humanos possibilitou o reconhecimento dos direitos subjetivos de personalidade, de caráter não patrimonial.

Embora tal processo de reconhecimento por parte do direito positivo tenha-se iniciado no século XIII, pode-se dizer que o direito privado só lhes reconheceu no século XX na maioria dos países ocidentais. No Brasil, a Constituição de 1988 foi o marco definidor. "Somente em fins do século XX se pôde construir a dogmática dos direitos de personalidade, ante o redimensionamento da noção de respeito à dignidade da pessoa humana, consagrada no art. 1º, III, da CF/88" (DINIZ, 2009, p. 119).

Os direitos da personalidade são derivados direto da dignidade da pessoa humana, embora alguns se apliquem às pessoas jurídicas. Servem para materializar os valores que emanam da dignidade e possibilitam sua tutela pelo Estado que deve garantir-lhes, defendendo-se de seus atos e de atos de outras pessoas.

$\mathrm{O}$ art. $1^{\circ}$, III da Constituição coloca a dignidade da pessoa humana no centro do ordenamento jurídico. $\mathrm{O}$ art. $5^{\circ}$ dispõe que "todos são iguais perante a lei, sem distinção de qualquer natureza, garantindo-se aos brasileiros e aos estrangeiros residentes no País a inviolabilidade do direito à vida, à liberdade, à igualdade, à segurança e à propriedade" 
para, a seguir, enumerar diversos incisos qualificando uma série de direitos individuais sem, no entanto, limitá-los aos expressos ou positivados.

O Código Civil de 2002, em consonância com a nova ordem constitucional, cuida dos direitos da personalidade entre os artigos 11 e 21 . Fala da integridade física, do nome e da privacidade mas não estabelece numerus clausus, ou seja, um número fechado de direitos, deixando-se em aberto a serem complementados pela jurisprudência, doutrina e outras normas legais.

Os direitos da personalidade visam proteger a identidade de cada um. Os atributos que o tornam único, que lhe diferencia das demais pessoas no todo social é o objeto. Tutelam a vida, a integridade psicofísica, a liberdade, a honra, a imagem, a privacidade. Dito de outro modo, "os direitos da personalidade são direitos comuns da existência, porque são simples permissões dadas pela norma jurídica, a cada pessoa, de defender um bem que a natureza lhe deu, de maneira primordial e direta" (DINIZ, 2009, p. 120).

Enumera-se os direitos da personalidade em a) direito à integridade física, mormente ao domínio sobre o próprio corpo, b) direito à integridade intelectual, como a liberdade de pensamento e propriedade intelectual, c) direito à integridade moral, como a intimidade, a privacidade, a imagem, a honra e d) direito à integridade social, como a educação, a saúde, a liberdade de associação, a sindical.

Caracterizam-se como absolutos, pois são oponíveis erga omnes; instransmissíveis e inexpropriáveis, por não poderem passar à titularidade alheia; irrenunciáveis, pois nenhum ato tem o poder de abrir mão deles; vitalícios, pois nascem com a pessoa e permanecem até a sua morte, podendo, inclusive, sobreviver ao titular; imprescritíveis, não desaparecendo com a inércia do titular; e extrapatrimoniais por não terem como objeto um bem externo à pessoa, patrimonial, dizendo respeito ao "ser" e não ao "ter".

A lesão a direito da personalidade é chamada dano moral, conforme preceituado pelo art. 5', V da Constituição. O Codigo Civil também o prevê: “art. 12. Pode-se exigir que cesse a ameaça, ou a lesão, a direito da personalidade, e reclamar perdas e danos, sem prejuízo de outras sanções previstas em lei”.

Embora consagrado atualmente, o dano moral não estava previsto de fato pelo ordenamento jurídico pátrio até 1988. Antes disso, embora se encontrasse julgados esparsos no judiciário, a regra era a sua negativa e não havia nenhum consenso na doutrina. Vozes argüiam sua possibilidade e vozes argüiam sua impossibilidade. 
Reconhecido juridicamente, o dano moral contrapõe-se ao dano patrimonial e, por isso, também é chamado de dano extrapatrimonial. Esta foi a primeira forma de conceituálo, por exclusão: o dano que não for patrimonial (econômico) será moral.

Fala-se que o dano moral fere direito personalíssimo, atingindo a esfera da subjetividade humana, ou do seu plano valorativo em relação ao meio social. Priva os bens que possuem valor fundamental à individualidade pessoal, "inerentes à sua personalidade ou reconhecidos pela sociedade em que está integrado" (CAHALI, 2005, p. 22). Fala-se em sofrimento psíquico, dor, angústia, desprestígio, traumas psicológicos, falta de privacidade, degradação física. O dano moral causa um abalo no bem-estar psicofísico, uma redução da subjetividade da pessoa.

A expressão dano "moral" é muito criticada, mas sempre há a ressalva de, por estar enraizada no Direito, ser improdutivo buscar outra denominação. De fato, se o dano moral causa lesão à integridade física, intelectual, moral e social da pessoa, o aspecto moral é só uma parte que não deveria conceituar o todo. Tal dificuldade se deve fundamentalmente porque definiu-se o dano moral por exclusão ao patrimonial.

Paulo Eduardo Vieira de Oliveira (2010, p. 40) sugere que a denominação tecnicamente correta "porque melhor exprime o conceito jurídico do instituto, é dano pessoal ou dano à personalidade, tomando o termo pessoa em toda a sua ampla dimensão, compreendendo a integridade psicofísica, a intelectual, a afetiva, a moral e a social”.

A par dessas definições, constata-se que o assédio moral em geral e o assédio organizacional em particular afetam justamente os direitos de personalidade do indivíduo. Os verbos utilizados para caracterizar o assédio são sempre vexar, constranger, humilhar, intimidar, hostilizar, instrumentalizar. Tais atos de agressão não afetam, ao menos diretamente, o patrimônio do indivíduo e sim a sua personalidade, a sua subjetividade.

Os direitos da personalidade, na qualidade de materialização da dignidade da pessoa humana, são objetos juridicamente tutelados atingido pelo assédio. Deve-se ressaltar que, sendo a pessoa uma totalidade psicossomática, a proteção à sua personalidade é feita de forma integral. A despeito de a legislação especificar diversos momentos dos direitos da personalidade (direito à vida, à honra, à intimidade, à privacidade, à integridade física, ao nome etc.), isso não quer dizer estes são os únicos direitos relativos à personalidade nem que são departamentalizados, decompostos em várias partes. Pelo contrário, “os direitos da pessoa são interdependentes e se acham 
conexos entre si, na medida em que contam com um único fundamento, como é o valor ontológico da pessoa humana" (CAHALI, 2005, p. 60).

Vergonha e humilhação são elementos comuns nas vítimas de assédio. A humilhação é o sentimento de ser menosprezado, submetido, rebaixado, ultrajado pelo outro. A vergonha vem em seguida, impedindo o indivíduo de reagir, formando uma idéia negativa de si próprio.

O sentimento de incapacidade resultante do não atingimento das metas impostas pela empresa, a sensação de ter se tornado um objeto, a rejeição de uma organização que lhe agride visando sua expulsão. "O assédio moral pode provocar uma destruição da identidade" diz Hirigoyen (2010, p. 175).

$\mathrm{O}$ abalo à personalidade e aos direitos da personalidade pode ocorrer por diversas maneiras no assédio organizacional. A principal delas é o dano causado à integridade física e psíquica do indivíduo.

\subsubsection{A saúde do trabalhador}

Há registros de estudos associando doenças a certos tipos de trabalho desde a idade antiga, em Roma e Grécia. Porém foi a revolução industrial que fomentou a discussão do problema, haja vista que reunia grande número de trabalhadores nas fábricas e permitiu que se estabelecesse um vínculo de fato entre a doença e o labor. O marco da medicina do trabalho moderna remete ao século XVIII com o médico italiano Bernardino Ramazzini.

Os empregados estavam expostos a jornadas extenuantes e condições insalubres que os legava à própria sorte. Com a introdução do uso das máquinas industriais, os acidentes eram freqüentes e não havia nenhuma proteção; cada um deveria zelar por sua saúde individualmente e os danos causados eram considerados efeitos colaterais inevitáveis do sistema. Foi nesse momento que começaram a surgir leis que estabeleciam condições de proteção à saúde obreira como a Lei de Peel britânica de 1802, considerada a primeira lei trabalhista da história.

No ano de 1833, surgiu o Factory Act que aplicava-se à toda indústria têxtil limitava o trabalho do menor, previa escolas nas fábricas e acompanhamento médico às crianças. Inicia-se a medicina do trabalho, considerada, pela evolução apresentada por 
Sebastião Geraldo de Oliveira (2010), a primeira etapa da proteção à saúde do trabalhador. Nesta fase, que tomou força com o fordismo e o taylorismo, o médico adentrou na fábrica para resolver lesões ocasionadas aos trabalhadores para que estas não interrompessem o trabalho. Os médicos não tinham poder para estabelecer condições salubres de trabalho; apenas atendiam os lesionados.

O surgimento da ONU, da OMS e a Declaração Universal dos Direitos do Homem no período pós guerra promoveram o progresso social, o bem-estar físico e mental dos trabalhadores, a dignidade generalizada e outros mandamentos visando a melhoria das condições de vida. Surgiu a etapa da saúde ocupacional onde a ação deveria ser preventiva, atacando as causas das doenças dos empregados e não nas consequiências.

Essa fase preocupava-se com o ambiente de trabalho, que deveria ser mais favorável aos trabalhadores. Utilizou-se dos conhecimentos de profissionais de diversas áreas como juristas, médicos, engenheiros, arquitetos, psicólogos. Surgiu a ergonomia, com o escopo de adaptar o trabalho ao homem ao invés de o homem ao trabalho.

A terceira etapa é a da saúde do trabalhador. Surge nos anos 1970 na Europa e EUA, países de capitalismo central. Difere-se das anteriores porque, a partir de agora, há a participação dos trabalhadores organizados que deixam de ser meros espectadores e tornam-se protagonistas. Essa participação foi fundamental porque permitiu a visão do todo do problema: ao invés de se preocupar com cada trabalho desempenhado, todo o ambiente laboral deveria ser organizado de forma a garantir a saúde e o bem-estar.

É nesta fase que aparece a figura do meio ambiente de trabalho. A OIT aprova o Programa Internacional para o Melhoramento das Condições e do Meio Ambiente de Trabalho (PIACT) e as convenções 155 e 161.

\footnotetext{
O PIACT atua essencialmente em seis campos temáticos: segurança, higiene e meio ambiente de trabalho; duração do trabalho; organização e conteúdo do trabalho; condições de trabalho e escolha da tecnologia; ergonomia e relações entre o trabalho e o meio ambiente de vida (OLIVEIRA, 2010, p. 58).
}

Essa etapa é a mais impactante na legislação brasileira por ter sido absorvida pela Constituição, pelas leis previdenciárias e pela ratificação das convenções 155 e 161 . Ocorre que já se fala em uma nova fase, relacionada à qualidade de vida do trabalhador. 
A preocupação agora não se restringe à vida do trabalhador durante o trabalho e se preocupa com os elementos externos e com a satisfação de cada um com o seu labor. Essa nova etapa supera em muito as anteriores porque busca outro enfoque na figura do empregado.

\begin{abstract}
Agora, pretende-se avançar para além do paradigma da saúde do trabalhador; busca-se a integração deste com o homem, o ser humano dignificado e satisfeito com a sua atividade, que tem vida dentro e fora do ambiente de trabalho, que pretende, enfim, qualidade de vida no sentido amplo (OLIVEIRA, 2010, p. 63).
\end{abstract}

Essa nova fase parece ser um passo a mais na absorção da idéia de dignidade da pessoa humana pelo trabalhador. A duração do trabalho, a remuneração, a organização, a satisfação do indivíduo com o seu trabalho são valores intrínsecos levados em conta agora. O alimento, o transporte, o lazer, a moradia, a educação são valores extrínsecos que compõem a totalidade da qualidade de vida do trabalhador

A despeito de serem esses valores deveras distante da realidade brasileira, o ordenamento jurídico pátrio apreendeu muitos destes conceitos, mormente das últimas etapas evolutivas. Além da proteção à vida e à integridade física, a Constituição tutela a saúde dos trabalhadores em diversas passagens.

$\mathrm{O}$ art. $6^{\circ}$ apregoa que "são direitos sociais a educação, a saúde, o trabalho, a moradia, o lazer, a segurança, a previdência social, a proteção à maternidade e à infância, a assistência aos desamparados, na forma desta Constituição". Por este dispositivo, depreende-se que até a etapa mais moderna da qualidade de vida do trabalhador está prevista na lei maior, em consonância à segunda geração de direitos humanos.

$\mathrm{O}$ art. $7^{\circ}$, XXII prevê a "redução dos riscos inerentes ao trabalho, por meio de normas de saúde, higiene e segurança". Mais adiante, preceitua:

Art. 196. A saúde é direito de todos e dever do Estado, garantido mediante políticas sociais e econômicas que visem a redução do risco de doença e de outros agravos e ao acesso universal e igualitário às ações e serviços para sua promoção, proteção e recuperação". 
O art. 200, em seu inc. II, diz que compete ao SUS “executar as ações de vigilância sanitária e epidemiológica, bem como as de saúde do trabalhador”. No inc. VIII fala em "colaborar na proteção do meio ambiente, nele compreendido o do trabalho".

Na seqüência da promulgação da Constituição, o Brasil ratificou as convenções 155 e 161 da OIT. A primeira assim define saúde:

Art. $3^{\circ}$. A saúde, com relação ao trabalho, abrange não só a ausência de afecções ou de doenças, mas também os elementos físicos e mentais que afetam a saúde e estão diretamente relacionados com a segurança e a higiene do trabalho.

Essa definição é saudada por Sebastião Geraldo de Oliveira (2010, p. 80) pelo "reconhecimento da saúde mental, assunto tão debatido atualmente, principalmente em razão do crescimento do estresse e do assédio moral".

A Convenção 155 estabelece que os países signatários devem instituir uma política nacional relativa à saúde, segurança e meio ambiente do trabalho, com reexame periódico que ateste sua eficácia. Visa prevenir danos à saúde do trabalhador oriundos de causas diversas, físicas e mentais.

A Convenção 161 complementa a 155, na medida em que institui os Serviços de Saúde no Trabalho. Estes devem atuar preventivamente buscando garantir a saúde física e mental em níveis ótimos. Estabelece a participação dos empregados, mas expressa que a responsabilidade pelo meio ambiente do trabalho é do empregador.

A CLT tem um capítulo dedicado à Segurança e Medicina do Trabalho compreendendo os arts. 154 a 201. Estabelece competências ao Ministério do Trabalho e Emprego para regulamentar normas de segurança do trabalho, prevê a intervenção das delegacias regionais do trabalho e regula expressamente algumas atividades relativas a equipamentos de proteção individual, iluminação, conforto térmico, instalações elétricas, prevenção à fadiga dentre outras. É neste capítulo que há a previsão de remuneração superior às atividades insalubres, norma deveras criticada porque a legislação deveria proibir ou limitar ao máximo o trabalho nessas condições, reduzindo a jornada e diminuindo a idade para aposentadoria dos trabalhadores submetidos à insalubridade.

Percebe-se que há uma evolução qualitativa no trato da saúde psicofísica do trabalhador que vai além do ambiente de trabalho e garante-lhe qualidade de vida em sentido amplo. Tal evolução representa a incorporação do conceito de dignidade da pessoa 
humana ao conceito de empregado dentro dos limites trazidos pelas relações de apropriação do trabalho alheio.

Como os conceitos sobre a saúde do trabalhador estão sempre em aberto, em permanente evolução, sempre há inovações. Margarida Barreto (2006 p. 53) lembra que já há pesquisadores a afirmar que "o desgaste operário não é resultante da multicausalidade dos fatores de risco específicos de uma determinada indústria, estado intrinsecamente relacionado com a organização do trabalho e a divisão das tarefas".

Como o indivíduo em sua realidade psicossomática está subsumido no meio social, somente a medição do biológico ao social permitiria explicar o histórico do corpo. Há que observar a relação do "individual e do biológico num acontecer socialmente determinado e construído, revelador da complexidade corporal dos trabalhadores, que produzem e reproduzem seus meios de existência e sua vida material” (BARRETO, 2006, p. 55). A saúde é vista então com um processo biopsicossocial.

O assédio moral, notadamente o organizacional, deve ser compreendido à luz desses avanços do entendimento sobre a saúde do trabalhador e conseqüente recepção pelo direito desses avanços. A saúde dos empregados é notoriamente ofendida pelo trabalho em organizações que tem na agressão moral seu método de gestão.

São diversos os impactos do assédio organizacional à saúde do trabalhador. No início, manifestam-se perturbações funcionais como cansaço, nervosismo, perda do sono, enxaquecas, distúrbios digestivos, dores na coluna. Hirigoyen fala que, no início, ainda é possível reverter essa situação. Mas perdurando o assédio, que é o que ocorre quando organizacional, "a pessoa assediada apresenta então apatia, tristeza, complexo de culpa, obsessão e até desinteresse pelos seus próprios valores" (HIRIGOYEN, 2010, p. 160).

Após os distúrbios funcionais, vem os psicossomáticos de todo gênero: variações bruscas de peso, gastrites, úlceras, problemas de tireóides, desregulação menstrual, hipertensão, vertigens, indisposição. É possível que o corpo capte o assédio antes do cérebro e o impacto físico redunde em efeitos psiquiátricos.

O estresse é outra conseqüência do assédio organizacional. O estresse é a resposta do corpo a uma demanda externa sobre ele exercida. Apresenta três fases: o alarme, quando o organismo percebe o estímulo e prepara a reação, alterando o seu equilíbrio; a resistência, quando o estímulo é persistente e o corpo tenta restabelecer o equilíbrio, gerando desgaste; e a exaustão, quando a resistência sucumbe ao estímulo. 
Os pesquisadores reconhecem largamente o trabalho como possível fator estressante, mormente quando a pressão é alta e os prazos são curtos. O desgaste ao corpo e à mente são significativos, podendo levar até ao esgotamento do indivíduo, o chamado burnout.

Além destes impactos, deve-se frisar que atividades manuais repetitivas geram uma série de lesões no corpo, chamadas de Lesão por Esforço Repetitivo (LER). Essa pode ser a consequiência do assédio moral organizacional nas profissões de repetições de atos simples, monótonos, que exigem sempre o mesmo movimento do corpo.

\footnotetext{
Nas relações autoritárias, que submetem e inferiorizam, exigem e não reconhecem o outro como legítimo outro na convivência, a saúde é abalada, a doença se precipita, se adianta, se acentua e se instala. Manifestam-se distúrbios e dano psíquicos variados, que podem alterar as condutas e modificar a personalidade (BARRETO, 2006, p. 192).
}

Na passagem acima transcrita, Margarida Barreto resume os impactos do assédio organizacional nos indivíduos. Quando fala em submeter, inferiorizar, não reconhecer o outro, está claramente afirmando que a dignidade da pessoa humana não é respeitada nas organizações que praticam assédio organizacional. Quando fala em alteração de condutas e modificação da personalidade, tem-se que os direitos relativos à personalidade foram atacados. Quando fala em abalo à saúde e manifestação da doença, o direito à saúde do trabalhador, em suas diversas acepções, foi o lesado.

Em alguns setores da economia é mais fácil visualizar a ocorrência de assédio organizacional. Pela estrutura funcional e pela centralidade na economia adquirida nos últimos anos, os bancos representam locais de trabalho onde a pressão é política de gestão e o desrespeito aos direitos dos bancários é a regra. 


\section{O ASSÉDIO MORAL ORGANIZACIONAL NOS BANCOS}

Ao desenvolvimento do capitalismo industrial em grande escala correspondeu o desenvolvimento do capitalismo financeiro. As grandes indústrias demandaram o surgimento de grandes bancos, mormente após a atuação das corporações em caráter transnacional.

O processo de aceleramento da globalização sob a égide do neoliberalismo ao fim do século XX fortaleceu o sistema financeiro global de forma nunca antes vista. Grandes conglomerados bancários expandiram seu capital velozmente, aumentando sua importância para a economia global e o seu poder perante os países.

A centralidade adquirida na economia e o seu modo de fazer lucro tornam os bancos locais de intensa pressão sobre o trabalho de seus empregados e de fácil constatação da presença de assédio moral organizacional.

O presente capítulo localizará tal modalidade de assédio nos bancos. O estabelecimento de metas draconianas, os mecanismos de avaliação, a apresentação de casos práticos via entrevista com bancários e as ações trabalhistas e previdenciárias mais comuns na categoria bancária serão abordados de modo a permitir fácil visualização do assédio enquanto modo de gestão do trabalho bancário.

\subsection{O Capital Bancário}

Os bancos possuem particularidades em relação a outros setores da economia que serão abordados para a melhor elucidação do problema. Sua forma de acumular capital e o papel que desempenha tornam o seu funcionar propício para a ocorrência de assédio, principalmente na modalidade organizacional.

Parte do dinheiro acumulado pelas empresas realiza alguns movimentos técnicos que, por se tornarem complexos, adquiriram autonomia. Essa parte do dinheiro não retorna para o processo de reprodução do capital industrial, sendo necessário permanecer enquanto dinheiro para realizar esses movimentos técnicos. 
As empresas necessitam pagar e receber de muitas pessoas, o que demanda uma reserva de meios de compra ou de pagamentos. Esse pagar e receber dinheiro, por sua vez, exige a guarda do tesouro, balanços de conta, contabilidade apurada, meios de compensação, títulos de crédito etc. Karl Marx identificará aí uma espécie de divisão do trabalho porque, pela complexidade e autonomia dessas operações, outra categoria de capitalistas realizará tais operações.

A transformação dessa parte do dinheiro em meios de circulação e pagamento terá custos de circulação próprios, pois demanda trabalho, custos e não acumula lucro industrial. Torna-se um negócio especializado.

Pagamentos, recebimentos de dinheiro, operações de compensação, escrituração de contas-correntes, guarda do dinheiro etc., todas essas operações técnicas, separadas dos atos que as tornam necessárias, transformam em capital financeiro o capital nelas adiantado (MARX, 2008, p. 423).

Esse entesouramento nada mais é do que sua guarda e contabilização inicialmente, podendo ser considerado meros caixas das indústrias. Desenvolve-se plenamente quando a essas funções básicas somam-se as de emprestar, tomar emprestado e negociar a crédito. É quando esse dinheiro entesourado torna-se capital produtor de juros.

O dinheiro insere-se na produção capitalista enquanto capital quando pode valorizar-se, expandir o seu valor. Nos bancos, pode-se dizer que o próprio capital torna-se uma mercadoria porque se valoriza com os juros ao retornar do prestatário ao prestamista. Um exemplo elucida a questão.

Um banco empresta $\mathrm{R} \$ 100,00$ a uma indústria qualquer, têxtil por exemplo. Suponha-se que essa indústria consiga uma taxa de lucro de $20 \%$. Assim, ao utilizar o valor emprestado pelo banco, o que é feito com a produção e venda de roupas, a indústria transforma os R\$ 100,00 iniciais em R\$ 120,00, pois obteve lucro ao inserir o capital emprestado no processo produtivo. Se o banco emprestou os $\mathrm{R} \$ 100,00$ a uma taxa de juros de 5\%, a indústria retornará ao banco R\$ 105,00: os $\mathrm{R} \$ 100,00$ inicialmente emprestados mais os $\mathrm{R} \$ 5,00$ de juros. O banco terá lucrado $\mathrm{R} \$ 5,00$ com os $\mathrm{R} \$ 100,00$ que estavam parados, à espera de utilização; a indústria terá lucrado R \$ 15,00 ao solicitar empréstimo de $\mathrm{R} \$ 100,00$ ao banco, devolvendo o valor com juros de 5\%. 
O dinheiro entesourado pelos bancos agora é emprestado a terceiros, retornando acrescido de juros. Torna-se capital para o banco, que o empresta a juros, e para o prestatário, que o insere no processo de produção e reprodução real e obtém mais-valia a partir da sua realização. O banco não aliena uma mercadoria qualquer; ele aliena ao prestatário o valor-de-uso do capital, a possibilidade deste dinheiro funcionar como capital, valorizando-se através da extração de mais-valia, gerando lucro para quem o toma emprestado. Desse plus que o capitalista obtém com o dinheiro emprestado, o capitalista ficará com uma parte (seu lucro médio) e o banco receberá outra parte na forma de juros.

Tem-se uma clara divisão do trabalho então. Os bancos mantem uma quantidade de capital parada, à espera de uma empresa que demande empréstimo. Essa empresa é quem inserirá o dinheiro no processo produtivo, gerando lucro para si e pagando juros ao banco. A condição para isso é a existência prévia desse montante entesourado no banco, à espera de utilização econômica.

Há uma oposição entre duas figuras capitalistas, o financeiro e o industrial (ou comercial ou de serviços ou agrícola etc.). O primeiro dispõe de capital a ser investido produtivamente, mas não o realiza. Enquanto o capital está em suas mãos, não rende juros e quando rende juros, não está em suas mãos. O segundo só dispõe como seu o lucro obtido pelo investimento do capital no processo produtivo. Não dispõe do capital em si porque este está comprometido no processo de reprodução.

O valor obtido com a inserção do dinheiro no processo reprodutivo divide-se em duas partes: o lucro do empresário e o juro do banco. Quanto maior o lucro extraído daí, menor o juro e vice-versa. O juro, então, representa o fruto da propriedade do capital, o modo pelo qual os bancos valorizam seu capital; o lucro do empresário deriva da aplicação produtiva deste capital emprestado, que não pertence ao empresário, mas por este é utilizado e valorizado.

Uma parte do lucro, o juro, se apresenta de per si como fruto do capital numa significação definida; e a outra, o lucro do empresário, se revela fruto específico do capital em significação oposta: uma deriva da nua propriedade do capital, e a outra, da simples aplicação desse capital, do capital em movimento, ou das funções exercidas pelo capital ativo (MARX, 2008, p. 498).

Lucro e juro são categorias qualitativamente diversas oriundas do lucro bruto obtido pelo prestatário. Não são meras cotas repartidas do lucro bruto, são valores diversos 
obtidos pelas formas diversas de se relacionar com o capital. Enquanto o capitalista ativo valoriza o capital através da sua aplicação, seja na transformação da matéria-prima e criação de mercadorias, seja na comercialização das mercadorias, seja na prestação de um serviço, o capital financeiro valoriza-se pela sua simples propriedade, pelo seu acúmulo nos bancos, que lhe pode emprestar a juros a quem lhe dê aplicação prática e devolva-lhe em seguida o montante emprestado acrescido do juro extraído do lucro bruto.

Por valorizar-se sem necessidade de aplicação produtiva, Marx considera o capital financeiro a forma fetichista por excelência do capital. A forma geral do movimento capitalista seria D - M - D', ou seja, o capital seria aplicado, transformando matéria-prima em mercadoria a ser vendida, valorizando o capital inicialmente investido. Aqui, o capital realiza sua marcha completa para valorizar-se, marcha essa que envolve a produção e a circulação de mercadorias.

Para os bancos, a fórmula seria apenas D - D’, o dinheiro se valorizaria por si só, sem aplicação prática. Se um banco empresta $\mathrm{R} \$ 1.000,00$ a uma empresa com taxa de juros de $10 \%$, basta-lhe apenas esperar a data prevista no contrato para o pagamento que os $\mathrm{R}$ \$ 1.000,00 terão se transformado em $\mathrm{R} \$ 1.100,00$ sem nenhum esforço, independente do processo de produção e circulação. É dinheiro que gera dinheiro.

\footnotetext{
O capital aparece como fonte misteriosa, autogeradora de juro, aumentando a si mesmo (...) O capital produtor de juros é o fetiche autômato perfeito - o valor que se valoriza a si mesmo, dinheiro que gera dinheiro, e nessa forma desaparecem todas as marcas de origem (MARX, 2008, p. 520).
}

As metáforas utilizadas por Marx dimensionam a avaliação que ele fez do capital portador de juros. Este pareceria gerar dinheiro de modo tão natural quanto crescer é natural a uma árvore; proporciona juros da mesma forma que uma pereira proporciona uma pera; o dinheiro valoriza-se com o empréstimo assim como o vinho valoriza-se em uma adega com o tempo.

Diferente do capital industrial, comercial ou agrícola, o capital produtor de juros gera dinheiro como capital em si, capital-dinheiro, sem depender da produção, da oposição à força de trabalho extraindo-lhe mais-valia, da quantidade de matéria-prima disponível. Essa forma do capital é em si uma mercadoria, tendo seu preço expresso pela taxa de juros 
cobrada pelo seu empréstimo. Reproduz-se por sua própria existência, podendo reproduzirse infinitamente. O que pode acarretar danos graves.

O crédito representa a entrega de alguém a outrem de um valor determinado de dinheiro que deve ser devolvido em determinado prazo com o acréscimo dos juros. Baseiase em confiança e deve ter base monetária entesourada. No início do sistema de trocas, a moeda, o dinheiro materializado, representava os valores devidos por devedores a credores.

O desenvolvimento econômico capitalista tornou o sistema de trocas muito mais complexo e rápido. Mercadorias passaram a ser vendidas não com o dinheiro, mas com uma promessa de pagamento a ser realizada em determinado prazo. Surgem as letras de câmbio e demanda-se crédito para isso. As letras circulam como meio de pagamento até o dia em que vencem e devem ser compensadas.

O problema é que o sistema de crédito é baseado em dinheiro virtual, fictício, que só existe como promessa. Isso possibilita a circulação de dinheiro virtual em montante infinitamente maior que o dinheiro real entesourado. Dois exemplos trazidos por Marx (2008, p. 532) dimensionam isso.

Em 1840, um banqueiro de Yorkshire afirma que a circulação total de promessas de pagamento e as obrigações totais dos bancos ingleses que poderiam ser exigíveis à vista somariam $£ 153$ milhões, mas os bancos só dispunham em ouro de $£ 14$ milhões. Em 1842, um economista crê que a câmara de compensação londrina efetua pagamentos médios diários no valor de $£ 3$ milhões, mas que só seriam necessários $£ 200$ mil em reserva de dinheiro para o fazer.

Atualmente o problema só se agrava. Em 1997, as transações financeiras globais representavam cerca de 15 vezes a produção mundial total. Em 2011, as movimentações financeiras representavam quase 70 vezes a produção mundial (HALIMI, 2012, p. 24). Dinheiro que gera dinheiro.

Nos primórdios do desenvolvimento mercantil, os banqueiros guardavam os fundos de reserva dos comerciantes para que estes pudessem pagar os credores, receber dos devedores e realizar comércio internacional. Com moedas diferentes em cada país, os bancos possibilitaram a conversão de uma moeda em outra, permitindo pagamento de dívidas entre comerciantes de países distintos.

A partir do momento em que esse dinheiro estesourado passou a ser emprestado a juros, o papel dos banqueiros mudou. Passaram a acumular dinheiro emprestado para emprestá-lo. 
De modo geral, o negócio bancário, sob esse aspecto, consiste em concentrar grandes massas de capital-dinheiro emprestável, e assim, em vez do prestamista isolado, os banqueiros, representando todos os prestamistas, se confrontam com os capitalistas industriais e comerciais (MARX, 2008, p. 534).

Os bancos tem a tarefa, então, de arrecadar o máximo possível de dinheiro disperso, concentrá-lo e torna-lo capital portador de juro. Isso acontece de vários modos. Armazenam dinheiro produtivo ou especulativo, quantias grandes ou pequenas. Entesouram o capital das empresas que atuam nos diversos ramos da economia, os salários dos trabalhadores, enfim, a renda de todas as classes sociais. Tais montantes individualmente considerados não teriam o poder de valorizar-se. Mas, entesourados nos bancos, as quantias somadas tornam-se vultosas somas de capital-dinheiro a ser emprestado a juros, valorizando-se sem produzir única mercadoria sequer.

Além do dinheiro vivo armazenado, engloba o capital bancário os títulos de crédito e demais papéis lançados ao público. O dinheiro entesourado representa o capital próprio do banco e depósitos, que nada mais são do que empréstimos feitos pelo público ao banco também a juros. A magnitude das transações bancárias e a virtualidade do dinheiro levam ao fato de que a maior parte destes valores é fictício, só existe nos registros de contabilidade dos bancos.

O segredo do capitalismo financeiro é constituir capital fictício, especulativo, futuro, ampliando as somas em circulação mesmo que tais somas não existam nas reservas bancárias. Enquanto a economia funciona regularmente, estará tudo bem desde que não haja uma corrida para os bancos.

Os títulos de crédito circulam tanto, passam de mãos em mãos de tal forma que parecem adquirir autonomia em relação aos valores entesourados que, em tese, representam. Um título de crédito é um documento necessário ao exercício do direito literal e autônomo nele mencionado (COELHO, 2009, p. 373). É uma representação de um capital a ser empregado, uma proporção da mais-valia a se realizar.

A maior parte deste "capital-dinheiro" é puramente fictícia. Excetuado o fundo de reserva, todos os depósitos, embora sejam créditos contra o banqueiro, não tem existência efetiva. Quando utilizados nas operações de compensação, funcionam como capital para os banqueiros, desde que estes os tenham 
emprestado. Os banqueiros entre si pagam os cheques recíprocos sobre os depósitos que na realidade não existem, fazendo as deduções correspondentes nos saldos contábeis (MARX, 2008, p. 623).

Tal ocorre porque uma mesma peça de dinheiro pode servir de base a mais de uma concessão de crédito. Um banco que disponha de $\mathrm{R} \$ 1.000,00$ pode emprestar este valor a A, B e C ao mesmo tempo, a juros. Este valor é fictício, uma promessa de pagamento. Se A, B e C utilizarem o valor e pagarem ao banco, este terá triplicado o valor de forma fantasmagórica. O problema é se $\mathrm{A}, \mathrm{B}$ e $\mathrm{C}$ não conseguirem honrar seus compromissos e os novos donos dos três títulos forem cobrar-lhes ao banco. Nesse caso, haverá uma quebra, que foi o que houve em 2008.

Vários efeitos ocorreram na economia a partir da expansão do crédito. Há uma tendência ao nivelamento da taxa de juros cobrada pelos diversos emprestadores à medida que expande o sistema creditício. Diminui o custo de circulação porque o dinheiro é um destes custos. O dinheiro físico é suprimido nas transações, circula mais velozmente. Acelera o processo de reprodução, aumenta o tempo entre o ato de comprar e o de vender. E impulsiona o desenvolvimento das sociedades por ações.

Com crédito abundante, as empresas ampliam sua escala de produção de forma que capitais privados isolados não conseguem acompanhar. Há uma associação de capitais e as empresas tornam-se sociais ao invés de estritamente privadas. O capitalista ativo torna-se um mero dirigente da empresa e os acionistas são os proprietários do capital, assemelhando-se a capitalistas financeiros. Dissocia-se a figura do dono e do dirigente. Financeiriza-se por completo a economia.

Quando Marx escreveu O Capital, a economia concorrencial estava em seu auge. A partir de então, houve uma concentração brutal de capitais, formando grandes empresas que monopolizavam seus nichos, muitas vezes através de cartéis. Nos EUA e na Europa, grandes sociedades por ações cresciam e esmagavam os concorrentes menores, contando para isso com a aliança com grandes bancos.

Os bancos dispõem de quase todo o capital-dinheiro disponível na economia. $\mathrm{Na}$ condição de intermediadores dos pagamentos das empresas e de emprestadores de dinheiro a juros, acumulam quantias cada vez maiores que podem ser emprestadas e aplicadas em empreendimentos cada vez maiores também. Quando as empresas da produção e circulação crescem, aumentam a quantidade de capital entesourado no banco. O processo desenvolve-se como uma bola de neve. 
Lênin observou esse processo de concentração bancária na virada do século XIX para o século XX. Várias indústrias intermediárias cederam espaço a umas poucas indústrias gigantescas e monopolistas. Com os bancos, verificou-se o mesmo fenômeno. Alguns números ajudam a visualizar o problema.

Entre 1895 e 1911, não mais que seis grandes bancos dominavam a Alemanha e, neste período, ampliaram seus estabelecimentos de 42 unidades para 450. Os três grandes bancos franceses aumentaram o seu capital próprio de 200 para 887 milhões de francos entre 1870 e 1909. Na Inglaterra, os depósitos bancários cresceram, de 8,4 para 23,2 bilhões de marcos entre 1880 e 1908 (LENINE, 2008, p. 34 e ss.). Desnecessário lembrar que tal concentração tem como efeito a supressão ou a subordinação dos bancos menores.

Se poucos grandes bancos centralizam a quase totalidade do capital-dinheiro disponível, as empresas que demandam crédito tornam-se reféns desses monopólios. As movimentações das contas dessas empresas avolumam-se em proporções gigantescas, dando um salto de qualidade. Primeiro, permitem aos bancos conhecer profundamente as condições de funcionamento de todas as empresas. Segundo, permite-lhes controlar essas empresas, liberando ou restringindo o crédito. Por fim, os bancos passam a decidir o futuro das corporações, determinando sua rentabilidade, capitalização etc.

Os bancos expressam uma espécie de contabilidade geral da economia de mercado. Seu fortalecimento desenvolveu o capitalismo de forma concentradora, engendrando grandes corporações a esmagar as pequenas e médias em todos os ramos, inclusive o bancário. Monopólios, trustes, cartéis ameaçam frequentemente um modelo econômico que se pretendia baseado em livro concorrência.

A movimentação das contas correntes, a compensação de títulos de créditos de todas as empresas por alguns poucos bancos submetem aquelas a estes. O passo seguinte é a união pessoal do sistema financeiro com o produtivo, principalmente pela detenção e controle de ações e pela participação de representantes dos bancos nos conselhos de administração das demais empresas. Os bancos especializam diretores e criam departamentos voltados a cada segmento que subordina. Deslocam pessoas para cuidar de empresas do ramo de energia, químico, metalúrgico, serviços, comércio, pequenas e médias empresas. Acompanham de perto de forma individualizada cada setor específico.

Da mesma forma que as grandes empresas submetem as pequenas, os capitalistas financeiros submetem todos os demais ao ponto de permitir a Lênin concluir, ainda em 1916, que "o século XX assinala, pois, o ponto de transformação do velho capitalismo para 
o novo, da dominação do capital em geral para a dominação do capital financeiro" (LENINE, 2008, p. 46).

A monopolização crescente do período analisado por Lênin tornou os países de origem das grandes corporações insuficientes para satisfazê-las. O mundo foi repartido, então, pelos países ricos, fase conhecida pela história como neocolonialismo. A voracidade das grandes empresas e grandes bancos culminou com as grandes guerras, mas legou ao mundo uma economia submetida em tudo aos desígnios do capital financeiro.

Após trinta anos de crescimento contínuo da economia global do pós-guerra, o neoliberalismo imperou no mundo com sua política de desregulamentação do mercado e redução do Estado. Pavimentou-se a hegemonia do capital financeiro no processo de globalização.

Gaulejac sugere que três fenômenos transformaram o funcionar da economia na virada do século XX para o XXI: o império da economia financeira sobre a industrial, a desregulamentação estatal causada pela desterritorialização das empresas e a fusão das telecomunicações com a informática.

A lógica financeira é do lucro rápido, instantâneo, em detrimento do planejamento industrial. $\mathrm{O}$ avanço tecnológico responde a esta demanda na medida em que a cotação da bolsa de valores varia diariamente, e os acionistas e dirigentes acompanham cada passo. Busca-se o lucro imediato a qualquer custo e as empresas devem se adaptar.

O capitalismo industrial calcava-se na qualidade dos produtos inseridos nas leis de oferta e procura. "Hoje, a própria empresa se tornou um produto financeiro cujo valor é diariamente avaliado conforme a medida dos mercados" (GAULEJAC, 2007, p. 42). Sua rentabilidade é medida em tempo real e as empresas menores que atuem em sua coordenação, mesmo que não cotadas em bolsa, devem se enquadrar.

Encurta-se o tempo entre a publicação de balanços de resultados, submete-se as corporações a analistas financeiros que demandam rentabilidade imediata, a busca pela produtividade é em curto prazo, há pressão constante dos mecanismos de avaliação de desempenho, proliferam-se contratos de trabalho voláteis que permitam ajustes rápidos em resposta às exigências do mercado financeiro, dissemina-se a remuneração dos altos funcionários na forma de stock-options, atrelando seu desempenho ao da empresa.

O capitalismo familiar não pode ser desconsiderado, mas cede espaço cada vez mais a um poder despersonalizado. Há cem anos, sabia-se que a família Ford era dona das empresas Ford. Atualmente, milhares de pequenos acionistas individuais sequer conhecem 
as empresas de que são cotistas. Os chamados investidores institucionais reinam: fundos de pensão, fundos coletivos de aplicação, sociedades de seguro, bancos de investimento.

Quando uma pessoa física aplica seu dinheiro na bolsa, intermediado por uma empresa do mercado financeiro, o faz querendo obter lucros, rentabilidade. Antes, os donos diretos da empresa preocupavam-se com o longo prazo, com estratégias duradouras e com a permanência de seu empreendimento ao longo do tempo. Hoje os managers estão mais preocupados com a pressão do mercado do que com a empresa em si, que virou mera mercadoria.

François Chesnais (2011, p. 48) sugere que a propriedade capitalista adquiriu a forma de uma propriedade patrimonial. "Esta é dominada pela figura do proprietárioacionista e, mais precisamente ainda, pelo acionista institucional possuidor de títulos de empresas". Os detentores de ação não seriam meros emprestadores de dinheiro, seriam proprietários em posição de exterioridade da produção.

Por essa propriedade patrimonial, os acionistas conseguiriam influenciar a repartição das rendas em duas dimensões: na distribuição da riqueza entre salários, lucros e renda financeira e na distribuição entre o que seria lucro do investimento e dividendos e juros financeiros. Esses juros e dividendos seriam redirecionados às finanças, constituindo o que o autor francês define como "moderno entesouramento".

Como os dirigentes devem satisfação apenas ao mercado de capitais, aumenta a pressão sobre o trabalho, precarizando os contratos de emprego e dificultando a associação sindical. Como tudo tem que dar lucro o tempo todo, os recursos humanos também tem o seu valor medido em tempo real. Os trabalhadores tornam-se "agentes sociais de desempenho" (GAULEJAC, 2007, p. 50). A financeirização econômica acirra o conflito capital $\mathrm{x}$ trabalho em prol do primeiro.

\footnotetext{
Os assalariados foram as verdadeiras vítimas da chegada dos proprietáriosacionistas. É contra eles que se exerce o novo poder administrativo. Foram eles que sofreram e vão continuar a sofrer, desconsiderando acontecimentos políticos e sociais maiores, os efeitos das normas de rentabilidade impostadas pelos financistas (CHESNAIS, 2011, p. 55).
}

A consolidação dos estados nacionais foi uma resposta à consolidação das economias nacionais. A partir do momento em que as empresas crescem e expandem-se para outros países, há uma crise porque a política e o direito não conseguem acompanhar: o 
Estado permanece limitado ao seu território, mas as empresas não. Há uma economia global, mas a governança global ainda é fragilíssima. Sem a mediação estatal, as corporações correm o mundo e impõem suas lógicas aos países, muitos deles de PIB inferior ao valor acionário das multinacionais que lhe exploram.

O Direito do Trabalho sofreu com isso. O mundo financeiro não tem a menor preocupação com as condições de seus empregados e a globalização caracterizou-se por financeira e não por social. Os organismos multilaterais (FMI, BIRD, BID) pressionam os países a flexibilizar seu mercado de trabalho, condicionando isso a concessão de empréstimos e financiamentos. Nem a crise de 2008 foi suficiente para reverter essa tendência, verificável na gestão que o FMI dá à crise atual europeia.

A atual fase da acumulação financeira mundial é analisada por François Chesnais sob perspectiva histórica. O período pós-guerra caracterizou-se por desenvolvimento industrial intenso, avanços tecnológicos e investimentos pesados em infraestrutura para reconstruir principalmente a Europa. O capital portador de juros retoma suas forças após o choque do petróleo, entre as décadas de 70 e 80 do século XX.

Por acumulação financeira, entende-se a centralização em instituições especializadas de lucros industriais não reinvestidos e de rendas não consumidas, que têm por encargo valorizá-los sob a forma de aplicação em ativos financeiros - divisas, obrigações e ações - mantendo-os fora da produção de bens e serviços (CHESNAIS, 2011, p. 37).

O crescimento vigoroso por três décadas ininterruptas criaram um excedente de capital que não tinha condições de ser reinserido no processo produtivo. Some-se a isso a obrigatoriedade de os assalariados abrirem contas em bancos para o recebimento dos salários e tem-se as bases para o fortalecimento do mercado financeiro, que gera dividendos sem produzir nada.

A "idade de ouro" manteve a economia fortemente aquecida a ponto de o capitalismo ingressar em uma nova crise de superprodução. A demanda pelas mercadorias produzidas não acompanhava a ampliação da oferta e os lucros industriais tornavam-se cada vez menos atrativos. A criação de crédito foi a forma encontrada pelos governos para manter a economia em atividade. 


\begin{abstract}
A reconstituição de uma massa de capitais procurando se valorizar fora da produção, como capital de empréstimo e de aplicação financeira, tem por origem o esgotamento progressivo das normas de consumo e a baixa rentabilidade dos investimentos industriais (fato visível nas estatísticas) (CHESNAIS, 2011, p. 38).
\end{abstract}

O mercado financeiro saiu tão fortalecido que abriu linhas de crédito para realizar empréstimos aos governos, alimentando-se das dívidas públicas destes. Uma combinação de taxas de juros superior ao da inflação e do crescimento do PIB destes países criou uma situação de bola de neve, onde os juros da dívida são cada vez maiores e absorvem generosos pedaços dos orçamentos nacionais. A dívida se recria e acumula quantidades formidáveis de capital financeiro através "titulização" de dívidas públicas, espinha dorsal do sistema.

A absorção dos bônus dos tesouros possibilitou aos investidores institucionais centralizarem mais capital portador de juros que os bancos, com destaque para os fundos de pensão e as sociedades de seguros. Títulos de dívidas públicas, empréstimos a empresas mediante obrigações e a particulares mediante hipoteca, juros interbancários baixos e criação de crédito conformam as bases do regime de acumulação financeira. Segundo Chesnais (2011, p. 43), ao fim dos anos 90, os ativos dos investidores institucionais já era em muito superior ao PIB dos países da OCDE.

A globalização neoliberal impulsionada a partir dos governos Reagan nos EUA e Thatcher na Inglaterra não é neutra: é a mundialização do capital em geral e a mundialização financeira em particular. Concentrou poder e riqueza no mercado financeiro, os extratos superiores da classe capitalista.

Os organismos multilaterais impuseram aos países medidas que visavam reforçar essa predominância do capital portador de juros. Privatizações de empresas públicas e da previdência dos trabalhadores, cortes nas receitas fiscais dos estados, flexibilização de leis trabalhistas, política de câmbio flutuante, liberdade de circulação dos capitais, tudo era feito na medida exata exigida pelos investidores institucionais, localizados que estão no topo da cadeia alimentar do capitalismo. Ao invés de os bancos financiarem a economia real, é a economia que financia os bancos.

As inúmeras crises financeiras, tendo a iniciada em 2008 como a mais grave, devem-se à incompatibilidade entre o que o mercado financeiro exige da economia real e o que essa pode lhe dar. As finanças são insaciáveis e buscam ganhos obtidos pela variação 
de preço de seu patrimônio e não pela transformação de matéria-prima em mercadoria ou uso de um bem.

O mundo financeiro força o mundo produtivo a atuar em seu ritmo frenético, o que nem sempre é possível. O volume elevado de crédito liberado para uma produção futura contradiz-se com a busca por resultados imediatos que os investidores almejam. Crises são inevitáveis. "Como a alquimia, o comércio ilimitado de capital repousa no mito da criação de riqueza ex nihilo. Não há restrições, regulações. O mito, contudo, desmorona" (RIMBERT, 2011, p. 7).

A crise das hipotecas imobiliárias americanas que levou o sistema financeiro mundial à lona em 2008 é a prova cabal da força adquirida pelas finanças. Dois filmes são fundamentais para a compreensão da crise: o documentário "Trabalho Interno", dirigido por Charles Ferguson e o longa "Margin Call - O Dia antes do Fim", dirigido por J. C. Chandor. Os filmes dimensionam o que ocorreu, como ocorreu e porque ocorreu.

"Trabalho Interno" inicia demonstrando como os bancos da Islândia, um país com PIB de US\$ 13 bilhões, adquiriram uma dívida de US\$ 100 bilhões. O documentário mostra a apropriação da política pelo mercado financeiro nos EUA, mas que ocorreu da mesma forma no resto do mundo - basta lembrar que o então candidato Lula teve que divulgar um documento público antes das eleições de 2002 afirmando que respeitaria os contratos (principalmente com os bancos!) e, eleito, nomeou um ex-diretor do Bank of Boston para a presidência do Banco Central.

Nos EUA, os chairmans do FED e os secretários do tesouro são todos oriundos dos grandes conglomerados financeiros. Isso resultou numa absoluta desregulamentação deste mercado. Os bancos e entidades não bancárias levaram sua insaciabilidade por produzir dinheiro a partir do dinheiro às últimas consequências. A superprodução de imóveis era alimentada por liberação de crédito intensa e despreocupada. Quando um banco quebrou, quebraram todos e milhões de americanos perderam suas casas.

O filme "Margin Call" mostra os bastidores de um grande banco na véspera da crise. Mostra bem quem são as pessoas que trabalham no topo do sistema financeiro mundial, como ganham milhões em bônus, qual sua formação, sua ética. Ambos os filmes são imprescindíveis a quem queira compreender de fato a maior crise econômica desde 1929.

Para tentar evitar as crises e por causa de uma crise, foi criado o Comitê da Basiléia em 1974 para tentar regular o funcionamento dos bancos. Suas normas não expressam 
poder efetivo, sendo meras recomendações. E visam sempre a auto-regulação dos bancos, o que denota a força destes em sua busca pela liberdade plena de funcionamento sem intervenções.

O primeiro acordo foi elaborado em 1988, batizado de Basiléia I. Visava a supervisão de precaução, mecanismo que prevê dificuldades potenciais que prejudicassem os bancos. "O objetivo da supervisão de precaução é não mais administrar a atividade dos bancos, mas orientá-la a uma prudência maior, dando ênfase à regulação do mercado" (PLIHON, 2011, p. 30). Este acordo levou à entrada em cena das agências de avaliação de riscos, instituições que ficaram famosas na crise iniciada em 2008 por atestarem a qualidade de instituições financeiras que quebraram em série, contrariando as avaliações feitas. Os parâmetros utilizados são rentabilidade e liquidez, pressionando os bancos e acirrando a concorrência.

A regulação dos bancos baseou-se a partir de então nos mecanismos de controle interno desenvolvidos pelas próprias corporações e no controle por parte do mercado, através da concorrência e da rentabilidade e liquidez. Regulação estatal só em caráter suplementar.

O segundo acordo surgiu na década seguinte e visava fortalecer as análises de risco interna. Incitava os bancos a qualificar seus instrumentos de avaliação de riscos, analisa-los pela perspectiva de seu conjunto, reforçar o papel dos auditores bancários e a disciplina ao mercado.

Tais acordos, meras recomendações, explicitam o modus operandi do mercado financeiro: pouca intervenção estatal, leis do mercado e auto-regulação. Os modelos de avaliação de riscos ganharam espaço. Profissionais altamente qualificados nas ciências exatas que atuam em departamento próprio calculam as possibilidades e perdas potenciais em um intervalo de tempo dado. Um sistema que trabalha com crédito e promessas de pagamento que vão muito além de seus reservas precisa de preocupar com a possibilidade de os números não baterem. E não bateram.

Dominique Plihon crê que os acordos de Basiléia favoreceram a crise que assolou o mundo com a quebra de várias corporações financeiras. Primeiro porque as avaliações de risco fizeram os bancos apertarem o crédito em momentos de turbulência e afrouxarem desmesuradamente em momentos de bonança, que não são eternos. Segundo porque muitos bancos transferiram seus riscos para fundos de investimentos não regulamentados. Terceiro porque muitos bancos não conseguiam detectar seus riscos e se lançaram em 
aventuras. Quarto porque a regulação prevista focava nos bancos individualmente e desconsideraram o sistema financeiro como um todo. "Não foram levadas em conta as relações entre os bancos e os atores não bancários, bem como os diferentes mercados financeiros (mercados futuros, bolsas, mercado imobiliário)” (PLIHON, 2011, p. 31).

Em 2010, anunciou-se o acordo Basiléia 3, com aplicação prevista para o longínquo ano de 2018.

O Brasil tem a Lei 4.595/64 como a norma mais importante de Direito Bancário, mas há uma regulamentação baseada também em atos do executivo. A normatividade bancária e financeira obedecia às políticas governamentais ao longo das décadas, que visava a concentração e internacionalização, originando o sistema financeiro atual.

A ditadura instaurada em 1964 no país iniciou o processo de reformas do sistema financeiro brasileiro. Como o modelo econômico adotado era contracionista e submetido ao capital internacional, a reforma bancária seguiu a mesma linha e privilegiou a formação de grandes conglomerados bancários, além de abrir-se ao mercado internacional.

\footnotetext{
Implementadas ainda nos anos 60, tais reformas criavam mecanismos de controle e fiscalização da moeda e do crédito na economia, estruturavam o mercado de capitais, institucionalizavam a correção monetária na remuneração de aplicações, permitiam aos agentes financeiros do país tomar empréstimos externos e repassálos internamente, articulando o sistema financeiro nacional ao internacional (JINKINGS, 2002, p. 46).
}

O governo militar incentivava a concentração de capital e a formação de grandes corporações monopolistas no sistema financeiro como um todo, mas havia políticas específicas para os bancos. Houve um estímulo às fusões e incorporações e restringiu-se a abertura de novas agências bancárias, forçando as incorporações dos menores pelos grandes. Entre 1965 e 1970, a participação dos dez maiores bancos no setor subiu de 32\% para 43\% (JINKINGS, 2002, p. 47).

Nesse período, já era possível perceber a participação de ativos monetários e o aumento de títulos não bancários do sistema financeiro. Diversificou-se e especializou-se a atuação das empresas no setor. Incluiu-se no sistema financeiras, bancos de investimento, seguradoras, sociedades de crédito imobiliário, instituições vinculadas à bolsa de valores etc. Potencializou-se a acumulação financeira nos mais diversos modos, concentrando o capital. 
Havia uma restrição à participação de capital externo nas atividades típicas de bancos comerciais, atividades monetárias, até os anos 80 . Porém, nas atividades financeiras não bancárias a participação do capital externo não parava de aumentar, associando as instituições nacionais e internacionais.

A internacionalização do sistema foi impulsionada pela Lei 4.595/64, que trouxe a especialização do sistema, mas a Resolução nº 63 do Banco Central de 1967 deu um passo decisivo nessa direção. Transcreva-se o quanto preceituado em seu primeiro inciso:

I - Facultar aos bancos de investimento ou de desenvolvimento privados e aos bancos comerciais autorizados a operar em câmbio a contratação direta de empréstimos externos destinados a ser repassados a empresas no país, quer para financiamento de capital fixo, quer de capital de movimento, observado o disposto nesta Resolução e nas demais normas legais e regulamentares em vigor.

$\mathrm{O}$ acesso ao capital internacional abriu o mercado brasileiro no momento em que o governo militar promovia o "milagre econômico". O resultado foi o endividamento externo público e privado acelerados e o impulso à formação de grandes instituições monopolistas vinculadas ao mercado mundial. A partir de então, os bancos nacionais tinham que se equiparar aos internacionais porque a concorrência tornou-se internacional e a participação das instituições financeiras no PIB saltou de $6 \%$ para $20 \%$ entre as décadas de 70 e 80 (JINKINGS, 2002, p. 53). Contribuiu também para o processo a instituição da correção cambial em 1968, igualando os riscos de um empréstimo externo ao de um interno. A seguir, o governo autorizou as demais empresas de capital produtivo, incluindo multinacionais, a realizar empréstimos externos.

$\mathrm{O}$ resultado das reformas bancárias da ditadura militar foi o fortalecimento dos grandes bancos privados nacionais e internacionais, redução da participação estatal no sistema, concentração do capital portador de juros e explosão da dívida externa.

Na década de 90, o neoliberalismo dominou a América Latina. Fernando Henrique Cardoso no Brasil, Salinas de Gortari no México, Carlos Menem na Argentina, Alberto Fujimori no Peru, dentre outros, cumpriam rigorosamente o receituário imposto pelos organismos multinacionais de privatizações, ajustes fiscais, abertura econômica, liberdade de capitais, estabilidade monetária e flexibilização (senão destruição!) do mercado de trabalho. 
Foi um período de hegemonia absoluta dos EUA no mundo após a derrocada soviética. O neoliberalismo era a ideologia dominante e o sistema financeiro já movimentava mais dinheiro do que os setores produtivos da economia. Nesse contexto, a reinserção do Brasil na ordem global foi mais submissa e dependente do capital externo do que já era antes.

Em 1990, iniciava-se o governo Collor, inserindo oficialmente o Consenso de Washington na política brasileira. A reforma do Estado e a abertura econômica começavam ali, recrudescendo após o Plano Real e a ascensão do PSDB ao poder. E o sistema financeiro tinha papel de destaque na reestruturação ocorrida.

O mercado de ações foi aberto aos investidores estrangeiros. Bancos nacionais recebiam empréstimos de investidores estrangeiros ou eram simplesmente adquiridos por estes. Liberou-se o fluxo de capitais e a remessa de divisas dos bancos de atuação local para suas sedes no exterior. Bancos estrangeiros abriam filiais no país e adquiriam instituições nacionais.

A alta liquidez do sistema financeiro dos países centrais desembocou no Brasil, atraídos que foram os capitais internacionais pelas altas taxas de juros aplicadas (que chegaram a 48\% em 1999), pela privatizações de dezenas de bancos públicos, estaduais e federais, e pelo endividamento crescente. A atração destes capitais era fundamental para o fechamento das contas do Plano Real.

\footnotetext{
Assim, desfrutando de ampla liberdade de acesso ao país, as instituições financeiras externas puderam escolher entre a participação no capital social de bancos privados nacionais, a aquisição do controle acionário de instituições por meio de processos de privatização ou liquidação, ou, ainda a instalação (ou expansão) de sucursais e subsidiárias no mercado local (JINKINGS, 2002, p. 64).
}

Segundo Nise Jinkings (2002, p. 66), entre 1992 e 2000, a participação de bancos com controle acionário estrangeiro aumentou de $6,9 \%$ para $27,4 \%$, ao passo que os bancos estatais viram sua participação reduzir-se de 52,7\% para 36,5\%. A concentração de capitais pode ser observada pelo fato de ter diminuído o número de instituições financeiras, mas ampliado seus ativos e movimentações.

A acumulação financeira verificada era impulsionada por políticas governamentais pró-mercado. Estimulava-se a fusão e incorporação dos menores pelos maiores, mantinha- 
se a taxa de juros nas alturas, liberava-se as tarifas bancárias, reduzia-se a carga tributária. O mercado financeiro aprisionava a política e a academia da mesma forma que nos EUA. Diversos economistas bradavam as palavras de ordem dos bancos travestidas de ciências econômicas. Tudo sob os aplausos da grande mídia, que apoiava amplamente a transferência de bilhões de reais dos cofres públicos aos grandes bancos.

A ascensão do PT ao poder com a vitória de Lula em 2002 permitiu a reconstrução do Estado brasileiro. Houve uma recomposição formidável de pessoal, fortalecimento das empresas públicas e incremento substancial de investimentos estatais. Mas a Carta ao Povo Brasileiro simbolizou um compromisso de que o governo se manteria fiel aos contratos e aos arranjos econômicos elaborados na gestão anterior. O governo Lula manteve intocada a estrutura financeira herdada: fortaleceu os bancos públicos, mas não reverteu as privatizações já realizadas.

No início do governo em 2003, sinalizações pró-mercados foram logo dadas. O governo aumentou a taxa de juros do Banco Central duas vezes em dois meses, ampliou o superávit primário sem que o FMI o exigisse, reformou a previdência dos servidores e emendou a constituição, retirando o teto de $12 \%$ dos juros cobrados pelos bancos.

Os bancos como um todo se beneficiaram enormemente do novo período de desenvolvimento e inclusão social iniciado em 2003. A taxa de juros despencou, mas continua entre as mais altas do mundo, o que possibilita elevados lucros às instituições financeiras. A ascensão social de mais de 36 milhões de pessoas que saíram da pobreza, a bancarização ocorrida no período - que nada mais é do que o acesso a um banco a quem nunca o teve - a ampliação do crédito, a elevação salarial de todas as camadas de trabalhadores, o aumento do emprego e o crescimento do PIB permitiram que os bancos aumentassem seu patrimônio de forma nunca vista.

Os bancos lucraram como um todo, mas os bancos públicos tiveram papel de destaque. Até os anos 90, primava-se pela redução dos bancos estatais, pela sua privatização ou pela redução de seu papel na economia. Revertendo essa tendência, os bancos públicos se fortaleceram na última década.

O governo se utilizou fartamente das empresas estatais, incluindo os bancos, como instrumentos de política de desenvolvimento. Em 2002, os investimentos das estatais foram inferiores a R \$ 20 bilhões; em 2009, o montante foi de cerca de R $\$ 90$ bilhões. Os bancos públicos ampliaram significativamente o volume de crédito liberado e criaram 
carteiras de crédito específicas para pessoas físicas de baixa renda e pequenos empreendimentos.

Quando explodiu a crise de 2008, os bancos privados liberavam um volume de crédito cerca de 30\% maior que os públicos. Em 2009, os bancos públicos aumentaram o volume de créditos em $57 \%$, enquanto que o aumento no setor privado nacional foi de $11 \%$ e o estrangeiro, 30\% (FARIA, 2010, p. 39), empatando a volume liberado.

A CEF tornou-se um dos principais vetores de políticas públicas, com destaque para o financiamento da habitação, a distribuição do Bolsa Família e a liberação de microcrédito. O Banco do Brasil resgatou uma filosofia pública de atuação, aumentando a liberação de crédito e adquirindo outros bancos. O BNDES, que desembolsara cerca de R\$ 150 bilhões entre 1995 e 2002, ofertou somente em 2009, no meio da crise financeira, R\$ 137,4 bilhões (FARIA, 2010, p. 49).

Um estudo do DIEESE com o desempenho dos cinco maiores bancos em 2011 põe o Banco do Brasil na liderança do mercado financeiro brasileiro com ativos que somam quase $\mathrm{R} \$ 1$ trilhão. A CEF aparece na quarta colocação, mas foi a que apresentou o maior crescimento entre 2010 e 2011, na ordem de 27,4\%. A lista completa-se com o Itaú Unibanco $\left(2^{\circ}\right)$, Bradesco $\left(3^{\circ}\right)$ e Santander $\left(5^{\circ}\right)$. Juntos, os cinco bancos representaram mais de R\$ 3,5 trilhões em ativos, com 452.693 empregados. Foi amplamente divulgado pela mídia que o lucro líquido dos bancos obtiveram lucro líquido, durante do governo Lula, de cerca de R\$ 200 bilhões, demonstrando a riqueza e o poder que estas instituições adquiriram.

Tais valores dão razão aos argumentos sempre levantados sobre a importância do controle dos bancos pelo Estado. Os bancos captam recursos de grande número de pessoas, físicas ou jurídicas, que precisam de proteção para que não percam os montantes confiados e, pelo peso crescente que as finanças tem na economia, sempre há o risco de uma crise em uma instituição contaminar todo o sistema.

No Brasil, a Lei 4.595/64 é o marco legal inicial do Direito Bancário. Esta norma define quais são as atividades privativas das instituições financeiras.

Art. 17. Consideram-se instituições financeiras, para os efeitos da legislação em vigor, as pessoas jurídicas públicas ou privadas, que tenham como atividade principal ou acessória a coleta, intermediação ou aplicação de recursos financeiros próprios ou de terceiros, em moeda nacional ou estrangeira, e a custódia de valor de propriedade de terceiros. 
Parágrafo único. Para os efeitos desta lei e da legislação em vigor, equiparam-se às instituições financeiras as pessoas físicas que exerçam qualquer das atividades referidas neste artigo, de forma permanente ou eventual.

Tal definição deve ser interpretada à luz da evolução do Direito de Comercial. Antes, as definições da empresa eram baseadas nos chamados atos de comércio, que não davam conta na nova realidade econômica. Hoje, a definição de empresa baseia-se na ideia de atividade, que englobaria três características: a economicidade, porque a atividade empresarial visa o lucro; a organização, porque a empresa organiza os chamados fatores de produção, incluindo o trabalho (resumido a apenas mais um "fator de produção"!); e a profissionalidade, porque a empresa atua de forma habitual, ininterrupta.

A delimitação expressa da lei sobre as atividades privativas de instituições financeiras deve ser interpretada sob a sua finalidade de proteção da economia popular, uma vez que as pessoas confiam aos bancos suas rendas, e de regulação a empresas que atuam com crédito e seu efeito de multiplicador monetário, o que pode trazer graves consequências à economia como um todo se mal utilizado. Tais instituições precisam de autorização e fiscalização do Banco Central, constituindo crime o exercício de atividade financeira não autorizada.

$\mathrm{O}$ art. 17 da Lei 4.595/64 delimita, então, como atividades privativas de instituições financeiras as que cumulam captação de recursos de terceiros para o seu empréstimo a juros em operações de mútuos, sendo exercidas tais atividades de forma habitual, empresarialmente organizada e com o intuito de obter de lucros. O art. 192 da Constituição Federal preceitua que leis complementares regulamentarão o sistema financeiro nacional, mas essas leis nunca foram aprovadas.

Como o capital financeiro tende a atuar transnacionalmente, o Conselho Monetário Nacional aprovou a resolução 2.723/00, que estabelece normas e procedimentos às instituições financeiras que atuem no exterior. As corporações que queiram atuar no estrangeiro precisam de prévia autorização do Banco Central, seja para instalar uma agência, seja para participação de sociedade estrangeira, e devem dispor informações que BACEN julgar relevante, dentre outras normas. Lado outro, instituições estrangeiras também precisam de autorização da autoridade monetária nacional para atuar no Brasil e submete-se à legislação pátria.

Da leitura do artigo 18 da Lei 4.595/64, depreende-se que na definição de instituições financeiras enquadram-se as bancárias, públicas ou privadas, e as não 
bancárias, entre as quais se incluiria cooperativas de crédito, sociedades de crédito, de financiamento ou de investimento e as caixas econômicas. Somente essas instituições podem desempenhar atividades privativas de instituições financeiras, podendo também desempenhar outras atividades não privativas, interpretação essa baseada no art. $5^{\circ}$, XIII da Constituição.

Os bancos obedecem a algumas normas exclusivas, que não se aplicam às demais instituições financeiras. Por ser a primeira e ter originado as demais, os bancos são as mais importantes empresas do capital portador de juros, diferindo-se por não se vincular a uma especialização, como o afirma Eduardo Salomão Neto (2011).

\footnotetext{
Conclui-se portanto que bancos são instituições creditícias de caráter genérico, cuja função é a captação e repasse de recursos sem o caráter de especialização em ou preponderância de certo tipo de negócio que caracteriza as sociedades de crédito, financiamento e investimento $\mathrm{e}$ as sociedades de arrendamento mercantil.
}

Três modalidades bancárias admite o direito brasileiro. Bancos comerciais proporcionam o suprimento de recursos para financiar o comércio, a indústria, os serviços e as pessoas físicas a curto e médio prazo. Bancos de investimento operam investimento, participação ou financiamentos para suprimento de capital fixo ou movimento de empresas privadas a médio e longo prazo. Bancos de desenvolvimento suprem recursos necessários ao financiamento de programas e projetos de desenvolvimento econômico e social dos estados onde tenham sede a médio e longo prazo, priorizando o setor privado. É facultado aos bancos o exercício de duas entre as atividades privativas de instituições financeiras.

Entre as instituições financeiras não bancárias, tem-se as sociedades de crédito, financiamento e investimento, sociedades de crédito imobiliário, companhias de hipoteca e cooperativas de crédito (SALOMÃO Neto, 2011, p. 69 e ss.).

Sociedades de crédito, financiamento e investimento financiam aquisição de bens e serviços e o capital de giro. Sociedades de crédito imobiliário aplicam os recursos coletados para financiamentos imobiliários. Companhias hipotecárias financiam a produção, reforma e comercialização de imóveis. Cooperativas de crédito baseiam-se na cooperação mútua de seus associados pela através da economia sistemática e uso comum do crédito. 
As instituições financeiras públicas podem assumir regimes jurídicos distintos. $\mathrm{O}$ Banco do Brasil é uma sociedade de economia mista, o BNDES é uma empresa pública e o Banco Central é uma autarquia por exemplo. Todos tem suas finalidades públicas legalmente delimitadas. $\mathrm{O}$ art. $18, \S 1^{\circ}$ da Lei 4.595/64 equipara às instituições financeiras, para efeito de normas específicas, a bolsa de valores, companhias de seguros e de capitalização, sociedades que distribuem prêmios em imóveis, mercadorias ou dinheiro, e pessoas físicas ou jurídicas que exerçam por conta de terceiros compra e venda de ações ou outros títulos perante o mercado financeiro ou de capitais.

A regulação da atividade bancária, no Brasil, é regida pelo Conselho Monetário Nacional, que tem a competência regulamentar de fato, e o Banco Central do Brasil, responsável pela execução e fiscalização em relação às atividades bancárias. A competência lhes atribuída pela Lei 4.595/64 tem "três objetos distintos: controle da moeda, controle das instituições financeiras, e controle das operações de câmbio" (SALOMÃO Neto, 2011, p. 96).

O CMN é composto pelo Ministro da Fazenda, que o preside, Ministro do Planejamento, Orçamento e Gestão e pelo presidente do Banco Central. Sua finalidade é formular a política da moeda e do crédito. O BACEN é composto por uma diretoria nomeada pelo Presidente da República, demissíveis ad nutum, tem competência exclusiva para emissão de moeda e seu presidente goza de status de Ministro de Estado.

A regulamentação do sistema bancário é feito de modo preventivo, induzindo o funcionar do sistema tornando obrigatório o que é visto como benéfico e proibindo o que é danoso. Os novos mecanismos de engenharia financeira são baseados em análises de riscos futuros e os órgãos de controle nacionais seguem a regra.

A maior participação dos bancos e demais instituições financeiras na economia é a síntese de sua concentração de riqueza e poder. A busca frenética por mais e mais capital é jogada com toda força sobre os ombros do trabalho. Se os bancos assumem alguma centralidade, os trabalhadores bancários também crescem de importância e o fortalecimento sindical da categoria faz-se necessário para resistir à (o)pressão.

O peso crescente do capital portador de juros e os avanços tecnológicos mudaram completamente o perfil de um empregado de banco, aumentando os desafios para a organização da categoria. Principalmente porque o assédio tornou-se mecanismo prioritário de gestão. 
3.2 O Trabalho Bancário

O objeto do trabalho bancário é o capital-dinheiro. Os empregados dos bancos manuseiam as operações de registro e controle de entrada e saída de dinheiro, organizando a captação de recursos e a distribuição dos valores. A gestão do capital portador de juros é o fundamento do trabalho bancário.

As transações financeiras se avolumam velozmente e os valores manuseados são cada vez maiores. Com os avanços tecnológicos, os procedimentos dos empregados bancários alteram-se ao longo do tempo, diminuindo a quantidade de papel em troca de dados armazenados eletronicamente. A ampliação das atividades desempenhadas pelos bancos também contribuiu para as mudanças.

Observar de perto a evolução do trabalho em um banco é fundamental para a compreensão do problema do assédio moral organizacional.

Nise Jinkings (1996) estabelece uma narrativa histórica sobre o desenvolvimento do trabalho bancário no Brasil a partir da industrialização getulista. Mudou-se de um modelo agrário para uma economia de base urbana, com o incremento da indústria, serviços e comércio. Tal deslocamento demandou o fortalecimento do setor bancário a lhe financiar e custodiar o capital.

Nas primeiras décadas do século XX, o trabalho bancário era baseado em operações de conta corrente, emissão de crédito e cobrança. Os empregados dos bancos realizavam trabalho manual de escrituração do movimento dos bancos, utilizando muitos papéis.

Como crescia muito o papel dos bancos no período e estes acumulavam capital intensamente, houve aí já alguns incrementos tecnológicos no sentido da mecanização das atividades. Entre as décadas de 20 e 50 do século passado, os bancários passaram a utilizar máquinas de datilografia, copiadores de gelatina, máquinas de calcular e cartelas contábeis, aumentando sobremaneira a produtividade dos empregados e a velocidade com que as operações eram realizadas.

Esse incremento da produtividade do trabalho via inovações tecnológicas erigiu as bases para acumulação financeira crescente por parte dos bancos. A partir disso, a quantidade de dinheiro manipulada pelos bancos cresceu exponencialmente, aumentando a importância deste setor na economia como um todo e facilitando o processo de 
concentração comum a essa atividade: a história dos bancos tornou-se sempre diminuição do número de instituições e aumento do número de agências.

Até os anos 60, a estrutura do sistema era dividida entre direção geral e agências. À matriz cabia a administração geral, com a alta cúpula, contadoria, inspetoria, fiscalização das agências, recursos humanos, câmbio e tesouraria. As agências ficavam com a contabilidade das entradas e saídas diárias e o atendimento ao público e seu suporte.

O gerente era o chefe comercial da agência e o contador, o chefe administrativo. Chefias intermediárias eram representadas por subgerentes, subcontadores e chefes de expediente. Os escriturários dividiam-se nos setores de conta corrente, cadastro, contabilidade, descontos de títulos, atendimento ao público e escriturando todas as movimentações realizadas. Os caixas apenas recebiam depósitos e pagavam cheques.

Jinkings (1996, p. 30) demonstra que o fluxo de trabalho era bem mais longo e lento. Um cheque de um cliente que o fosse descontar em uma agência passava pelas mãos do escriturário do balcão de atendimento, o controle de caixa registrava a entrada, o setor de firmas conferia a assinatura até que o setor de conta corrente verificava o saldo disponível e registrava o débito na conta do cliente.

Todos os dias se encerravam com o chamado "bate", quando todas as operações registradas eram verificadas em conformidade com os valores constatados nos caixas. Isso estendia as jornadas muitas vezes noite adentro, mormente nos períodos de balanço.

$\mathrm{O}$ ingresso de um empregado num banco era geralmente fruto da indicação de um cliente importante ou um funcionário de alguma hierarquia. Os salários eram baixos e os valores muito variados, porque não havia estipulação de valores por função desempenhada. A despeito da baixa remuneração, os empregados dos bancos eram recrutados entre classes sociais intermediárias, com algum grau de escolaridade e relações sociais para que demonstrasse conduta compatível ao atendimento dos clientes mais importantes, mormente proprietários capitalistas.

Desde esse período, exigia-se dos empregados bancários a representação social de uma pessoa honesta, íntegra, merecedora de confiança para guardar as rendas dos clientes. Ou seja, sempre houve uma cobrança para que interiorizassem valores éticos e culturais das classes proprietárias. Contudo, eram (e são) trabalhadores e pagavam por isso.

O trabalho extenuante e o baixo salário eram responsáveis por problemas de saúdes frequentes na categoria a ponto de se permitir o estabelecimento de nexo causal entre as atividades desempenhadas e as moléstias desenvolvidas. Em 1938, os bancários contavam 
com um serviço de tisiologia que constatou que cerca de $23 \%$ dos empregados portavam tuberculose, por causa da combinação ente alimentação insuficiente, horários intensos e locais de trabalho insalubres. Em 1942, detectou-se "psiconeurose bancária" em 259 bancários do Rio de Janeiro (JINKINGS, 1996, p. 31). Já nos primórdios era possível verificar a ocorrência de doenças físicas ou psíquicas geradas pelo trabalho em banco.

A ditadura implementada em 1964 deu-se em um período de intenso crescimento econômico e urbanização, condições objetivas que permitiram um movimento sindical e popular forte reivindicando sua participação no desenvolvimento do país. A ditadura veio para reprimir os movimentos contestatórios, intervir nos sindicatos, proibir greves e manifestações de pensamento, garantindo que continuaria o crescimento com concentração de renda. De militar, a ditadura só tinha a forma; o conteúdo pertencia às grandes empresas e grandes empresários.

A ditadura sufocou a resistência dos empregados bancários e favoreceu aos grandes bancos, reformando o sistema de forma a impulsionar a acumulação financeira. A reforma ampliou o rol de atuação dos bancos e os serviços ofertados e fez surgir grandes conglomerados bancários com atuação nacional e centenas ou milhares de agências espalhadas pelo Brasil.

As agências assumiram lugar de destaque para os bancos, pois alcançavam o grande público com suas ofertas de múltiplos serviços. $\mathrm{O}$ atendimento foi aperfeiçoado e boa parte dos empregados deslocou-se para as vendas de seus produtos. Um número crescente de mulheres foi incorporado ao trabalho bancário. A concorrência acirrada valorizava os clientes, mais numerosos e financiadores diretos dos bancos, por confiarem suas rendas às instituições bancárias e tomarem empréstimos.

Com milhares de agências geograficamente dispersas em busca da clientela e a atuação nacional das grandes instituições, foi necessário que mudanças organizacionais racionalizassem e controlassem as atividades desempenhadas. "Procedia-se à centralização do processo administrativo pelas matrizes dos bancos, ao mesmo tempo em que se descentralizavam os serviços prestados nas agências" (JINKINGS, 1996, p. 44).

As matrizes divulgavam manuais de instrução e regimentos internos disciplinando uniformemente a conduta dos empregados nas agências. Essas condições propiciaram a autonomização bancária no país. Uma combinação de aumento do mercado pela numerosa (e concorrida) clientela formada, aceleração dos fluxos de informações entre a matriz e as agências e aumento da produtividade pela redução de custos. 
A acumulação financeira permitiu a introdução de tecnologias que alteravam a estrutura de trabalho e aumentava a produtividade. Os grandes bancos inovavam primeiro, mas os avanços eram espalhados a seguir, alcançando cada agência bancária. Investia-se a partir de então pesadamente na informática.

Nos anos 60, iniciou-se a utilização de centros de processamento de dados (CPD) que agilizavam os registros contábeis, as operações em contas correntes e outras de sustentação de agências e das matrizes. Reduzia-se custos e concentrava-se todas as informações referentes às movimentações diárias nas agências e dados relativos à instituição.

As agências perderam autonomia em relação às operações contábeis, deslocadas que foram para os CPD's. O empregado bancário perdia o conhecimento sobre a contabilidade do banco; seu trabalho fragmentou-se e perdeu conteúdo, tornando-se mais operacional.

A forma do trabalhar dos bancários sofreu alteração semelhante à introdução do fordismo nas indústrias. Os trabalhadores perderam autonomia sobre os atos do seu trabalho, que estavam disciplinados por um comando externo, semelhante aos argumentos da organização científica do trabalho. Nas palavras de Nise Jinkings (1996, p. 48), "a racionalização transparecia na centralização administrativa e na padronização sistemática do processo de trabalho".

As matrizes enviavam normas de trabalho padronizando a conduta dos bancários, emitidas de centros de organização e métodos. Buscava-se racionalizar os atos de trabalho para que se tornassem mais rápidos e produtivos. A experiência adquirida no cotidiano da agência era centralizada no departamento de pessoal, apropriada pelos bancos e transformada em manuais rígidos e detalhados que submetiam os empregados.

Às transformações no conteúdo do trabalho bancário correspondeu a alterações nos próprios postos de trabalho. Funções eram extintas e outras criadas, mormente as relativas à informática. Surgiam cargos de operações simples e rotineiras, como digitadores e conferentes, ao lado de outras mais complexas que exigiam maior qualificação, como operadores, programadores e analistas de sistema.

Mesmo entre os novos profissionais de informática, é possível visualizar um intenso processo de separação entre trabalho intelectual e manual. No início da automação, um mesmo profissional dominava todo o funcionamento das máquinas, exercendo funções de operador, programador e analista. Essas funções foram desmembradas, especializando 
os empregados. Os bancários que atuavam na entrada e saída de dados sempre foram de menor qualificação e instrução.

Nos anos 70, informatizou-se o chamado sistema de apoio às decisões gerenciais. A alta cúpula dos bancos passavam a acompanhar as movimentações do mercado, operações dos seus bancos e informações dos seus clientes de forma mais efetiva, tomando decisões melhor fundamentadas.

$\mathrm{Na}$ década seguinte, as atividades de atendimento ao público foram informatizadas com a introdução de sistemas on line nas agências, com atualização automática das movimentações das contas correntes. As inovações mudaram a arquitetura das agências e a publicidade propalava a eficiência e modernidade dos bancos. A velocidade traduzia-se em lucros.

O conteúdo do trabalho de um caixa ampliou-se com a informatização. Estes podiam acessar diretamente no sistema as informações referentes ao cliente atendido, verificando sua conta e registrando sua movimentação. Aumentou o número de caixas e a produtividade individual com a intensificação do seu labor, ao passo que reduziu o risco de erros. O número de clientes atendidos por um caixa em um dia aumentou consideravelmente.

O setor de retaguarda, que dá suporte ao atendimento, perdeu importância e postos de trabalho. Cargos de digitadores e conferentes foram extintos, pois os atendentes verificavam diretamente os dados digitalizados. O uso de papel é reduzido ou eliminado. Proliferam-se caixas eletrônicos que permitem aos clientes acessar suas informações e utilizar os serviços dos bancos diretamente, $24 \mathrm{~h}$.

Gerentes de venda qualificados e informados sobre o mercado financeiro auxiliam os clientes, orientando-os sobre os produtos e serviços do banco de forma pessoal, fortalecendo o vínculo e a confiança.

O passo seguinte da automação foi a informatização da retaguarda. O sistema on line chegava às operações internas de cobrança, empréstimos, seguro, poupança. Esse passo significou a redução expressiva no uso de papel e na redução de custos através da extinção de postos de trabalho.

O final dos anos 80 trouxe mais inovação. O sistema de dados on line saía dos bancos e permitia o acesso e realização de operações bancárias externamente. É quando surgem os serviços de home banking, onde os clientes podiam acessar e utilizar suas contas através de computadores próprios conectados aos bancos ou por telefone. Internamente, 
leitoras ópticas realizavam compensação de cheques instantaneamente e terminais imprimiam talões.

O aperfeiçoamento do sistema de autoatendimento e home banking altera até mesmo a formatação das agências. Uma parte da agência é dedicada aos caixas eletrônicos, com horário próprio de funcionamento e separada por paredes de vidro. Somem os arquivos de papel. O setor de retaguarda, cada vez mais reduzido, convive com o setor operacional, de atendimento ao público. Este divide-se entre os caixas e os gerentes de venda.

A década de 90 foi a de implementação do neoliberalismo no Brasil, trazendo como consequências a hegemonia do capital financeiro na economia nacional e uma crise social sem precedentes, com a explosão do desemprego e da precarização do trabalho, representada por terceirizações, informalidade, achatamento salarial e enfraquecimento dos sindicatos.

Nos bancos, cada vez mais fortes e concentrados, as inovações tecnológicas se aceleravam, alterando o conteúdo do trabalho e, por conseguinte, o perfil dos empregados. A informatização aumentava a produtividade dos trabalhadores bancários ao passo que aumentava a intensidade do labor. As leituras e transmissões de dados feitas automaticamente por computadores permitiu o aumento exponencial das operações realizadas por dia.

A comunicação é priorizada. Com a concorrência acirrada entre as instituições que restaram, em número sempre decrescente, a captação da clientela e o atendimento ao público são o foco dos bancos. Duas mudanças destacam-se aqui: o esvaziamento dos serviços de retaguarda e a exteriorização do atendimento.

Os serviços mais simples são informatizados, reduzindo ou eliminando os postos de trabalho da retaguarda. Não há mais necessidade de conferência de assinaturas ou do saldo da conta para a compensação de um cheque por exemplo; é tudo feito automaticamente por leitura eletrônica. Os empregos nessa área foram drasticamente reduzidos e o que sobrou foi terceirizado. "Fechamentos de agências, de centrais de processamentos de dados, de serviços e de compensação, além da extinção de setores inteiros das instituições, têm implicado demissões em massa no setor" (JINKINGS, 2002, p. 124).

Como a força da grana ergue e destrói coisas belas, mesmo as funções criadas pelas inovações tecnológicas eram destruídas por mais inovações. $\mathrm{O}$ atendimento por telefone fez proliferar os call-centers, gerando postos de trabalho de telefonistas. Na sequência, os 
infernais menus eletrônicos reduziram o número de atendentes, reservados apenas para tarefas mais complexas. As centrais de processamento de dados extinguiram os setores que concentravam documentos. Depois, as próprias CPD’s foram extintas. Ao invés de manter profissionais de informática de criação em seus quadros, tornou-se mais fácil comprar softwares de empresas especializadas.

As atividades que demandavam menor qualificação também foram extintas. Verificação de documentos e operações de compensação de cheques foram terceirizados. Para os bancos, sua atividade fim consiste agora no atendimento ao público. E foi nisso que investiram.

Canais externos de atendimento receberam pesados investimentos e foram informatizados. Caixas eletrônicos foram instalados aos milhares, inclusive fora das agências. Surgem os bancos 24 horas com atendimento em horário integral. A propagação da internet tornou possível realizar diversas operações pelo computador, sem sair de casa ou do trabalho. Centrais de telemarketing atendiam o público via telefone.

O conceito de banco virtual ganha força nessa época, com a ampliação das possibilidades de realização de atendimentos sem a presença física dos clientes. Estes passaram a dispor de cartões eletrônicos com chips que lhe abriam as portas à virtualidade. Cartões de crédito e débito disseminam-se, reduzindo o uso de cheques e dinheiro em papel.

Em um período de desemprego crescente, a combinação entre automação, terceirizações e os processos de fusão, incorporação e privatização dos bancos tiveram um impacto dramático no trabalho bancário. A década de 90 reduziu a menos da metade os empregos bancários: iniciou com cerca de 815 mil funcionários e terminou com 400 mil (JINKINGS, 2002, p. 124). O saldo do neoliberalismo foi catastrófico.

À nova realidade do trabalho bancário correspondeu um novo perfil do trabalhador. As agências tornaram-se lojas de produtos e serviços financeiros. Isso demandou maior qualificação por parte dos bancários, que devem ter condições de captar clientes e atendelos de modo a satisfazê-los integralmente. Os novos bancários tem que ter o domínio dos movimentos do mercado financeiro, devem ser hábeis no trato personalizado aos clientes e ter capacidade de vendas. A excelência no atendimento é a marca com que os bancos ofertam seus produtos e serviços aos clientes, visando a sua fidelização.

Muda-se o perfil de um empregado de banco. Reduz-se o espaço dos escriturários e caixas, e cresce em importância o bancário vendedor, engravatado, nível superior 
completo, apto ao atendimento qualificado. Individualmente ou com alguma assessoria, devem vender títulos, seguros, consórcios, previdência e demais produtos e serviços dos bancos.

Nise Jinkings compila uma série de pesquisas realizadas na década de 90 por diversos institutos para constatar essa mudança de perfil. Diminuiu a quantidade de empregados vinculados à estrutura de apoio e atendimento simplificado: escriturários, caixa, chefias intermediárias. Cresceu a participação de técnicos de nível superior e especialistas em mercado financeiro. Combina-se o incremento tecnológico com um atendimento qualificado. Os empregados de baixa qualificação e funções simplificadas e repetitivas são terceirizados ou substituídos pela automação. Por outro lado, profissionais de alto grau de instrução são demandados para prestar um atendimento "de excelência" na venda de serviços financeiros, instruídos com as movimentações do mercado.

(...) os bancos contratam ou treinam uma fração da força de trabalho, cuja participação relativa cresce no total dos empregados no setor, para atender de modo personalizado aos segmentos da clientela considerados com elevado potencial de consumo dos serviços e "produtos" ofertados. É esta estratégia que leva à criação de gerências responsáveis pelos distintos tipos de contas correntes, divididas segundo os critérios dos bancos, conforme suas características de "nicho mercadológico" (JINKINGS, 2002, 184).

Entre 1993 e 1999, período de demissões em massa, somente os técnicos universitários tiveram variação positiva no número de empregados $(7,12 \%)$. Diretores ($18,64 \%)$, gerentes, chefes e supervisores $(-34,86)$ sofreram diminuição. Mais grave foi a retração dos empregos nos cargos inferiores: caixas, escriturários e auxiliares, recepcionistas, secretárias e operadores $(-39,75)$ e demais funcionários $(-81,40 \%)$. No período, houve queda de 38,5\% dos empregos bancários no país, caindo de 674.500 para 414.803 (JINKINGS, 2002, p. 188).

Verifica-se ainda o aumento do grau de escolaridade, com empregados de nível superior completo ou pós-graduados saltando de $28 \%$ para 36,7\% entre 1993 e 1998 (JINKINGS, 2002, p. 190). O grau elevado de escolaridade é uma exigência dos bancos para que os bancários vendedores possam atuar em situações no contato com o cliente que não sejam previstas nos manuais de conduta.

O empregado deve ter a capacidade de analisar cada cliente, compreender suas necessidades para poder ofertar-lhe os produtos certos. O bancário tem alguma autonomia 
e responsabilidade no desempenho do seu labor, não há como antecipar as situações. Os discursos oficiais dos bancos demandam profissionais inovadores, criativos, que suportem pressão, com perfil para os negócios.

A busca pela excelência torna-se um discurso incutido nos empregados. Cada um é responsável pelo desempenho do banco e deve se integrar ao espírito da instituição. A sua mobilização psíquica ocupa o espaço da mobilização física do taylorismo. Visa-se o desenvolvimento de habilidades específicas e o controle subjetivo do trabalhador.

As novas técnicas gerenciais utilizadas permitem que os bancos se apropriem das habilidades intelectuais e a experiência dos bancários, de modo que estes se integrem plenamente à ideologia dos seus empregadores e aumente a sua eficiência e produtividade. As metas pré-estabelecidas são rigorosamente controladas através do aumento da pressão.

A formação universitária seria um pré-requisito para a atuação bancária, demandante de grande habilidade relacional. Os conhecimentos teóricos somados à experiência prática são enaltecidos para quem deve trabalhar com multifuncionalidade, em um ambiente de intensa pressão por metas e concorrência.

Os novos bancários devem ter qualidades que lhe permitam progredir na carreira. Os bancos requerem ambição individual, que, bem mobilizada, converte-se em lucros altos e cumprimento de metas. Profissionais pró-ativos, que se integrem à ideologia e às práticas do banco, ambiciosos, que pretendam construir uma história na instituição. Esse é o novo perfil do empregado bancário.

O que os bancos brasileiros demandam é um tipo de bancário vendedor que se assemelhe ao tipo de profissionais que os bancos de investimento de Wall Street passaram a buscar a partir dos anos 80. Segundo Nicolas Guilhot (2011, p. 9), busca-se "funcionários jovens e ambiciosos cujas competências técnicas e capital escolar eram mais relevantes que a herança social".

Guilhot afirma que os negociantes (traders) do mercado financeiro americano passaram a ser contratados pela especialização em finanças ou direito, cujo atestado primordial é um MBA. Não mais profissionais com sobrenome famoso ou indicado por alguma relação pessoal: o mérito, a capacidade de crescimento tornou-se o diferencial que garante uma vaga em uma grande instituição investidora.

O mercado financeiro busca profissionais jovens e ambiciosos, atraídos por uma carreira onde é possível tornar-se um milionário da noite pro dia. Uma aquisição ou fusão 
bem feita pode mudar a vida de muita gente. E a ascensão social meteórica mexe com o imaginário desses trabalhadores altamente qualificados.

No cassino financeiro mundial, ganhar dinheiro depende de iniciativas que, muitas vezes, ignoram as fronteiras do lícito e do moral. Os padrões de conduta sociais são desrespeitados à medida que pode impedir um lucro milionário. O documentário "Trabalho Interno" mostra que muitos protagonistas da crise financeira de 2008 não demonstram a menor preocupação com a consequência de seus atos, atentando apenas para os ganhos estratosféricos.

É mais ou menos assim que os bancos brasileiros aprenderam a contratar seus empregados. Mobilizando sua subjetividade para o crescimento pessoal no trabalho, para a tomada de decisões correta no trato com um cliente, a capacidade de perceber uma oportunidade de vender um produto ao invés de outro. E isso se aprende na escola da vida.

Os primeiros anos do século XXI trouxeram uma guinada econômica considerável ao Brasil. A economia cresceu, o país se desenvolveu e o quadro de crise social deu espaço a um período de prosperidade. Os salários aumentaram, a participação da massa salarial no PIB também. O desemprego chegou ao nível mais baixo de sua história, atingindo a situação que os economistas definem como pleno emprego - onde a oferta de trabalho é superior à demanda.

A conjuntura socioeconômica geral influencia na situação dos bancários por óbvio. Na ditadura de 1964, a intervenção nos sindicatos atingiu os sindicatos de bancários; o neoliberalismo trouxe desemprego em massa, e na categoria bancária a tragédia também foi impiedosa. Logo, o período de desenvolvimento social inaugurado pelo governo Lula melhorou o quadro de emprego de banco.

Ao que diz respeito ao conteúdo do trabalho dos bancários, as transformações iniciadas nos anos 90 foram aceleradas. Investiu-se pesado em inovações tecnológicas, cresceu o número de atendimento à distância, as terceirizações das tarefas rotineiras e repetitivas intensificaram-se e as agências aperfeiçoaram-se enquanto pontos de venda de produtos financeiros. Após um período de demissões em massa e redução aguda dos postos de trabalho bancário, o emprego nos bancos voltou a crescer consistentemente. O processo de concentração do setor continuou.

Para compreender o momento atual do trabalho nos bancos, foram analisados três relatórios anuais de desempenho da FEBRABAN $(2003,2010,2011)$ e três pesquisas do DIEESE (2007, 2011a, 2011b) focadas no setor. 
Reverteu-se a tendência ao desemprego e os bancos tem apresentado saldos positivos de geração de empregos nos últimos anos. Entre 2002 e 2010, o números de empregados bancários saltou de 369.683 para 486.196. E os números continuam positivos.

Nos primeiros nove meses de 2011, houve um saldo de 18.167 novos empregos gerados, aumentando em 3,75\% o número de bancários no país e ultrapassando os 500 mil. O balanço apresentado pelo DIEESE (2011b) referente ao ano de 2011 deve ser analisado com o grão de sal porque há variações conjunturais que podem interferir no movimento, como o foram os processos de demissões do Itaú e do Santander. Mas podem ser observadas algumas tendências.

O saldo de empregos do setor bancário correspondeu a apenas 1,01\% dos empregos gerados na economia como um todo. Este número é incompatível com a importância que os bancos tem para a economia e demonstram que o setor emprega pouco.

O maior número de vagas geradas em números absolutos deu-se no Sudeste (7.915), região que concentra a maior quantidade de empregados. Porém, seguindo o processo de desconcentração econômica e distribuição de renda, foram as regiões mais pobres, Norte $(9,59 \%)$ e Nordeste $(8,46 \%)$, as que apresentaram maior expansão proporcional do emprego. O Sudeste teve a menor expansão $(2,69 \%)$, Centro-oeste $(3,1 \%)$ e Sul $(3,4 \%)$ também expandiram abaixo da média nacional.

Os admitidos nos três primeiros trimestres de 2011 tiveram salário médio de R\$ 2.487,74 contra $\mathrm{R} \$ 4.041,62$ dos demitidos, o que representa uma defasagem salarial de $38,45 \%$. O DIEESE sugere que o pouco tempo de permanência no emprego dos desligados pode ser a causalidade desse fato, porque quase $60 \%$ dos desligados tinha menos de cinco anos de casa. As desigualdades regionais explicam a diferença remuneratória dos admitidos entre as regiões, que varia de $\mathrm{R} \$ 1.568,26$ no Norte até $\mathrm{R}$ \$ 2.961,05 no Sudeste.

A desigualdade de gênero é notória. As mulheres representam 52,19\% das admissões contra 47,81\% de homens. Porém, o salário médio de um admitido é de R\$ $2.842,71$ contra $\mathrm{R} \$ 2.100,28$ das admitidas, uma diferença machista de $26,12 \%$.

A pesquisa confirma a tendência de contratação de profissionais jovens e escolarizados. O saldo dos admitidos mostra que 16.731 tinha até 24 anos e 6.789 tinha entre 25 e 39 anos. A partir dos 40 anos, o saldo torna-se negativo. A análise de instrução demonstra que possuíam ensino médio completo ou superior completo ou incompleto $97,91 \%$ dos admitidos contra 95,34\% dos desligados, aumentando ainda mais a 
escolaridade de uma categoria que já possui nível acima da média. Nada menos do que $76,61 \%$ dos admitidos cursam (34,15\%) ensino superior ou já o concluíram $(42,46 \%)$.

Os cinco maiores bancos do país possuíam, em setembro de 2011, 452.693 empregados. O Banco do Brasil era o maior empregador com 113.594 assalariados, seguido do Bradesco (101.334), Itaú (99.820), CEF (85.175) e Santander (52.77). No período, Itaú e Santander apresentaram saldo desfavorável, com mais desligados do que admitidos. Houve expansão do emprego no Bradesco (6.39\%), Banco do Brasil $(4,19 \%)$ e CEF (2,39\%), mas estes movimentos são sazonais e variam muito.

A concentração, internacionalização e privatização continuaram. Segundo dados da FEBRABAN (2011), entre 2000 e 2010, o número de bancos caiu de 192 para 157. Dentre estes, 88 são nacionais com ou sem capital estrangeiro, 60 são estrangeiros e sobraram apenas 9 públicos, estaduais ou federais.

Paralelo à redução do número de instituições bancárias, aumentou a quantidade de postos de atendimento, saltando, entre 2000 e 2010, de 54.075 postos para 242.798. As agências cresceram de 16.396 para 19.813; postos tradicionais foram de 9.495 para 12.670; postos eletrônicos variaram de 14.453 para 45.087; e os correspondentes não bancários explodiram de 13.731 para 165.228, mostrando a face da nova terceirização.

A concentração do setor também pode ser observada pelos valores movimentados. Entre 2000 e 2010, a captação de recursos de terceiros, envolvendo depósitos e fundos, variou de $\mathrm{R}$ \$ 501,3 bilhões para $\mathrm{R}$ \$ 2.271 bilhões. Transações com cartões de crédito variaram de $\mathrm{R} \$ 0,57$ bilhões para $\mathrm{R} \$ 2,96$ bilhões. Aproveitando-se do crescimento econômico do período, o número de contas correntes variou de 63,7 milhões para 141,3 milhões e as contas poupanças, de 45,8 milhões para 97,2 milhões.

Ainda segundo a FEBRABAN (2010), o lucro líquido dos bancos em 2010 foi de $\mathrm{R} \$ 54,3$ bilhões, $25,6 \%$ maior do que o ano de 2009 , sendo que o crescimento do PIB brasileiro no ano foi de 7,5\%. O ativo dos bancos cresceu quase 19,4\%, chegando a impressionantes $\mathrm{R} \$ 3,75$ trilhões.

O DIEESE (2007) observa que as fusões e aquisições, elementos da concentração do setor, levaram ao aumento da participação relativa dos cinco maiores bancos nos ativos totais. Entre dezembro de 2002 e dezembro de 2006, a participação dos cinco maiores variou de 51,3\% para 58,7\% dos ativos. Nesse período, as principais aquisições foram as do BANESPA e ABN AMRO Real pelo Santander, do Bamerindus pelo HSBC e do Nacional pelo Unibanco - que, mais tarde, viria a se incorporar ao Itaú. A FEBRABAN 
(2010) afirma que os dez maiores bancos detinham $86,79 \%$ dos ativos totais do setor em 2010 .

A concentração bancária é fortíssima no Brasil, com poucas instituições controlando o sistema. As novidades trazidas pelo século XXI é que a concentração seguiu intensa, mas agora ocorreu paralelamente à expansão dos postos de atendimento (decorrência do novo perfil assumido pelas agências, inovação tecnológica e terceirização) e com geração de empregos, o que sugere que a catástrofe social da década de 90 estava muito mais ligada à má situação geral da economia do que as transformações ocorridas nos bancos.

Porém, o fato de o emprego nos bancos ter aumentado nos últimos anos e a categoria bancária ter conquistado sucessivos reajustes salariais acima da inflação, elevando seu nível salarial, não pode ocultar o nível alarmante das terceirizações, tanto a terceirização tradicional, voltada aos serviços de retaguarda, quanto a terceirização via correspondentes bancários. Em ambos, os casos, a qualidade dos empregos gerados é precária e a legalidade das práticas, duvidosa.

A reestruturação produtiva determinada pelo neoliberalismo, sobre cujas bases erigiu-se o modelo bancário atual, demandava fusões, privatizações, inovação e terceirização. Esta última visa reduzir os custos operacionais, porque contrata empregados menos qualificados a salários mais baixos, e enfraquecer o movimento sindical porque cinge uma categoria no meio.

O discurso patronal enfatiza a concorrência internacional e usa-se largamente o argumento de que a ascensão social recentemente ocorrida trouxe uma bancarização em nível acelerado, sendo que os bancos precisam atingir os extratos inferiores da sociedade de classes brasileira.

A categoria bancária tem uma das mais importantes convenções coletivas do país, celebrada nacionalmente e estabelecendo uma série de direitos e garantias que elevam as condições objetivas de trabalho nos bancos em todo o Brasil. Os terceirizados, porém, estão fora do alcance da CCT bancária e trabalham em condições bem inferiores.

A Súmula 331 do TST é a principal norma a regular a temática, mas é largamente desrespeitada pelos bancos. Trabalhadores contratados por empresas prestadoras de serviços recebem instruções de empregados dos bancos, tem acesso ao sistema destes para lançar dados, utilizam seus equipamentos e tem seu trabalho controlado em qualidade e quantidade pelas instituições financeiras. 
Um trabalhador de determinada empresa terceirizada pode concretizar uma operação bancária à distância ao lançar on line no sistema do banco o resultado de seu processo de trabalho. Pode, ainda, digitalizar um contrato e igualmente proceder outras rotinas de trabalho, como juntar documentação de clientes, realizar análise de dados, arquivo, pesquisa de situação, digitação, dentre outras tarefas (CONTRAF, 2009, p. 253).

Os serviços preferenciais que os bancos terceirizam envolvem retaguarda, compensação de cheques, cobrança, tesouraria, teleatendimento e outros trabalhos manuais, repetitivos, que exijam pouca qualificação e escolaridade dos trabalhadores. A esses serviços, somam-se os já tradicionais segurança, limpeza e manutenção.

O problema é tão grave que a CONTRAF constata que, em 2007, havia cerca de 445 mil bancários formais no país segundo o CAGED do Ministério do Trabalho e Emprego, mas a PNAD do IBGE de 2006 mostrava que mais de 806 mil pessoas declararam trabalhar para o sistema financeiro. Não existe uma pesquisa com dados exatos, mas é possível que metade dos bancários não tenham seu contrato de emprego celebrado com os bancos, mas com empresas terceirizadas. Estes profissionais não estão submetidos à convenção coletiva nacional bancária nem à jornada de seis horas da categoria.

Em uma comparação relativa ao ano de 2008, tem-se que o piso dos bancários era de $\mathrm{R} \$ 1.013,64$ para escriturários e $\mathrm{R} \$ 1.416,51$ para caixas, mas os terceirizados recebiam salários que variavam entre $\mathrm{R} \$ 500,00$ e $\mathrm{R} \$ 700,00$. Terceirizados trabalhavam em média 8 horas e 48 minutos por dia contra uma jornada legal de 6 horas dos bancários. $\mathrm{O}$ auxíliorefeição de um bancário era de $\mathrm{R} \$ 15,92$ por dia, contra cerca de $\mathrm{R} \$ 6,00$ do terceirizados. Em dias de pico, um terceirizado realizava cerca de 250 autenticações diárias enquanto um bancário não faria mais do que 108. Vários outros direitos convencionais eram negados aos terceirizados, como PLR, auxílio-creche, programa de treinamento e qualificação profissional (CONTRAF, 2009, p. 255 e ss.).

Essa comparação permite afirmar que a terceirização no setor financeiro atenta contra a dignidade da pessoa humana insculpida no art. $1^{\circ}$, III da Constituição Federal. Conforme já visto, o conceito de dignidade utilizado pelo Direito Constitucional diz que ninguém poderá ser utilizado como objeto de outrem, ser coisificado em proveito alheio. Ao terceirizar amplas camadas de empregados para reduzir bruscamente seus salários e 
outros benefícios, os bancos e as empresas terceiras ferem de morte a dignidade desses profissionais, que laboram sob as péssimas condições supra mencionadas.

Ademais, o labor desses profissionais indica que eles fazem trabalho de bancário, no processamento ou verificação de documentos, na autenticação de cheques, no lançamento de dados no sistema do banco tomador etc. Todas essas são atividades fins dos bancos e geram uma enxurrada de reclamações trabalhistas. Transcreva-se a nova redação da Súmula 331, II e III do TST:

\footnotetext{
Súmula $\mathrm{n}^{\circ} 331$ do TST

Contrato de prestação de serviços. Legalidade

I - A contratação de trabalhadores por empresa interposta é ilegal, formando-se o vínculo diretamente com o tomador dos serviços, salvo no caso de trabalho temporário (Lei nº 6.019, de 03.01.1974).

(...)

III - Não forma vínculo de emprego com o tomador a contratação de serviços de vigilância (Lei $n^{\circ} 7.102$, de 20.06.1983) e de conservação e limpeza, bem como a de serviços especializados ligados à atividade-meio do tomador, desde que inexistente a pessoalidade e a subordinação direta.

(...)
}

Depreende-se do texto sumular que é admitida pelo Direito a terceirização das atividades meio da empresa, nunca das atividades fim. Logo, a questão deve ser analisar a situação concreta para saber se a atividade terceirizada é meio ou fim.

Reza a Lei 4.595/64 que instituições financeiras são "as que tenham como atividade principal ou acessória a coleta, intermediação ou aplicação de recursos financeiros próprios ou de terceiros, em moeda nacional ou estrangeira, e a custódia de valor de propriedade de terceiros”. Essa definição não dá nenhuma margem para a terceirização desenfreada que os bancos promovem nos mais diversos setores. Como pode a manipulação de documentos de clientes, a compensação de cheques, o lançamento no sistema de operações em conta corrente não serem consideradas atividades fins, nucleares dos bancos?

O sistema financeiro é rigidamente regulamentado e fiscalizado pelo Estado por lidar com patrimônio alheio e seria deveras temerário terceirizar a lida com este patrimônio a empresas que não são fiscalizadas da mesma forma e esse é o entendimento do TST. Uma rápida pesquisa jurisprudencial do tribunal de cúpula trabalhista assim o atesta conforme segue. 
RECURSO DE REVISTA. TERCEIRIZAÇÃO ILÍCITA. VÍNCULO DE EMPREGO. ENQUADRAMENTO COMO BANCÁRIO. As atividades-fim podem ser conceituadas como as funções e tarefas empresariais e laborais que se ajustam ao núcleo da dinâmica empresarial do tomador de serviços, compondo a essência dessa dinâmica e contribuindo também para a definição de seu posicionamento e classificação no contexto empresarial e econômico. São, portanto, atividades nucleares e definitórias da essência da dinâmica empresarial do tomador dos serviços. A contratação por empresa interposta é irregular, passível, até mesmo, de formação do vínculo de emprego diretamente com o tomador de serviços, na forma da Súmula 331/I/TST, que preserva a compreensão já sedimentada na antiga Súmula 256/TST, no tocante aos efeitos jurídicos decorrentes da terceirização ilícita. Segundo consta do acórdão regional, a Reclamante foi contratada por meio de empresa prestadora de serviços para executar tarefas tipicamente bancárias de processamento de envelopes que contêm pagamentos, depósitos, transferências, etc. Portanto, a fraude ficou caracterizada pela constatação de que a obreira realizava tarefas vinculadas à atividade fim do Banco reclamado, sendo reconhecida a terceirização ilícita. Por consequência, o vínculo empregatício se formou entre a Reclamante e o Banco reclamado, nos moldes dos artigos $2^{\circ}$ e $3^{\circ}$, da CLT e da Súmula 331/I/TST. Em face desse panorama fático, realizando a Reclamante atividades comuns àquelas desempenhadas pelos bancários, não há como the negar os direitos assegurados a essa categoria profissional, sob pena de desprestígio do trabalhador e premiação da discriminação, repugnada pela ordem jurídica. Recurso de revista conhecido e provido, no particular $2^{\circ}$ e $3^{\circ}$ CLT. (128500-92.2007.5.04.0005, Recorrente: Priscila Aline dos Santos Amaral Aredes, Recorridos: Banco Bradesco S/A e Fidelity Nacional Serviços de Tratamento de Documentos e Informações LTDA, Relator: Mauricio Godinho Delgado, Data de Julgamento: 09/11/2011, 6a Turma, Data de Publicação: DEJT 18/11/2011) (Grifos do autor).

No caso supra, a recorrente terceirizada processava envelopes referentes a pagamentos, depósitos, transferências e toda sorte de operações bancárias. O manuseio e conferência de documentos é atividade simples e repetitiva que os bancos terceirizam para empresas que pagam até mesmo um salário mínimo aos empregados, uma vez que estas não estão vinculadas à CCT e ao piso bancário. Acintosamente, trata-se de atividade nuclear bancária como corretamente decidiu o TST. 
consolidado, por ser o empregado pessoa física, prestando serviços de natureza não eventual a empregador, in casu , o Banco recorrido (terceiro-reclamado), sob a dependência deste e mediante salário, evidenciam-se os elementos subordinação, pessoalidade e onerosidade. Recurso de revista conhecido e provido. (Processo: TST-RR-1126/2004-032-01-40.7, Recorrente: Clebson Valentino da Costa, Recorridos: Unibanco - União de Bancos Brasileiros S/A, Service Bank serviços Tecnológicos e Representações Comerciais LTDA, Nossa Mão de Obra Serviços e Trabalho Temporário LTDA, $1^{\text {a }}$ Turma, Relator: Ministro Vieira de Mello Filho, data do julgamento: 08/10/2008)

Neste acórdão, o TST rechaçou a terceirização do setor de compensação de cheques, atividade que exige acesso aos dados dos clientes e que se caracteriza por basilar aos bancos.

Outra frente de terceirização, que conta com incentivo governamental, diz respeito aos correspondentes bancários. Criados por resolução do Banco Central desde a ditadura militar, passaram por diversas novas regulamentações, até chegar à atual Resolução 3.110/03, que dispõe que o BC assim resolveu:

\begin{abstract}
Art. $1^{\text {o }}$ Alterar e consolidar, nos termos desta resolução, as normas que dispõem sobre a contratação, por parte de bancos múltiplos, de bancos comerciais, da Caixa Econômica Federal, de bancos de investimento, de sociedades de crédito, financiamento e investimento, de sociedades de crédito imobiliário e de associações de poupança e empréstimo, de empresas, integrantes ou não do Sistema Financeiro Nacional, para o desempenho das funções de correspondente no País, com vistas à prestação dos seguintes serviços: I - recepção e encaminhamento de propostas de abertura de contas de depósitos à vista, a prazo e de poupança; II - recebimentos e pagamentos relativos a contas de depósitos à vista, a prazo e de poupança, bem como a aplicações e resgates em fundos de investimento; III - recebimentos, pagamentos e outras atividades decorrentes de convênios de prestação de serviços mantidos pelo contratante na forma da regulamentação em vigor; IV execução ativa ou passiva de ordens de pagamento em nome do contratante; V recepção e encaminhamento de pedidos de empréstimos e de financiamentos; VI - análise de crédito e cadastro; VII - execução de serviços de cobrança; VIII - recepção e encaminhamento de propostas de emissão de cartões de crédito; IX - outros serviços de controle, inclusive processamento de dados, das operações pactuadas; X - outras atividades, a critério do Banco Central do Brasil.
\end{abstract}

Em uma canetada, o BC liberou todo o sistema financeiro a terceirizar diversas operações típicas do trabalho em banco, como proposta de abertura de conta, pagamento, cobrança, análise de crédito e cadastro. Ou seja, operações simples de atendimento ao público são retiradas dos bancos e transmitidas a empresas terceiras. 
A legalidade dessas resoluções é deveras frágil. Com efeito, o art. 22, I da Constituição Federal é cristalino a afirmar que compete privativamente à União legislar sobre Direito do Trabalho. Legislar é tarefa restrita ao Congresso Nacional. Não pode o Banco Central criar, via resolução administrativa, uma nova categoria de trabalhadores ao determinar o que os bancos podem ou não terceirizar. Ademais, as condições de trabalho dos correspondentes bancários são em muito inferiores às de seus pares devidamente contratados pelos bancos, ferindo a dignidade da pessoa humana prevista no art. $1^{\circ}$, III constitucional.

Em sede de Direito do Trabalho, a Súmula 331 do TST afirma categoricamente a impossibilidade de terceirização de atividades fins, e todas as ações previstas no art. $1^{\mathrm{o}}$ da Resolução 3.110/03 o são, em desrespeito à jurisprudência consolidada pela Justiça do Trabalho e pelas definições de empregado e empregador trazidas pelos arts. $2^{\circ}$ e $3^{\circ}$ da CLT.

Contudo, uma decisão alvissareira do TST indica que a justiça especializada entende pela ilegalidade dos correspondentes bancários. Transcreva-se a ementa do acórdão:

RECURSO DE REVISTA. NULIDADE POR NEGATIVA DE PRESTAÇÃO JURISDICIONAL. Não se tem por caracterizada a indicada ofensa dos artigos 93, IX, da Constituição Federal e 832 da CLT. Do que se infere, o principal aspecto da controvérsia foi dirimido pelo Tribunal de origem ao consignar que a terceirização perpetrada entre a primeira reclamada e o segundo reclamado é ilícita, porque a reclamante desenvolvia atividades inerentes à de bancária, ou seja, atividade fim deste último. Assim, pouco importa se o Banco Central permite, por meio de resolução, a terceirização, porquanto a discussão se refere a uma realidade fática (vínculo empregatício da autora com o reclamado). TERCEIRIZAÇÃO ILÍCITA. BANCÁRIO. VÍNCULO EMPREGATÍCIO. A terceirização havida entre a primeira reclamada e o reclamado é ilícita, tendo em vista que a reclamante exercia atividades eminentemente bancárias. Assim, deve ser reconhecido o vínculo empregatício dela diretamente com o banco. Aplicabilidade da Súmula no 126 desta Corte. Recurso de revista de que não se conhece. (Processo: TST-RR-284800-38.2008.5.12.0001, Recorrente: Banco Panamericano S/A, Recorridos: Panamericano Administradora de Cartões de Crédito S/C LTDA e Fabiana da Silva, $7^{\mathrm{a}}$ Turma, Relator: Ministro Pedro Paulo Manus) (Grifos do autor).

A $7^{\text {a }}$ Turma do TST é categórica em afirmar a irrelevância das resoluções do BACEN. O acórdão faz referência à Resolução 2.707/00, que regulava os correspondentes bancários à época e fora posteriormente revogado pela 3.110/03. Para o TST, o que 
importa é analisar se terceirizou-se atividade meio da empresa tomadora, o que configuraria a ilicitude.

A desculpa oficial dos bancos e do BACEN é de que os correspondentes chegariam a lugares de difícil acesso onde seria inviável construir uma agência ou posto tradicional e permitiria o acesso aos serviços bancários de toda a população. Esse argumento cai por terra ao se verificar, em qualquer cidade grande, que há correspondentes bancários muitas vezes ao lado da agência do banco.

Outro fato que desmente essa teoria é a quantidade de correspondentes distribuídos nos estados. São Paulo é, por óbvio, o estado da federação que mais reúne agências e mais tem empregados bancários. Segundo o Sindicato dos Bancários de São Paulo, Osasco e Região (apud COUTINHO, 2011, p. 155 e ss.), em setembro de 2010, o estado tinha 6.633 agências e 42.176 correspondentes, ao passo que Roraima tinha 24 agências e 218 correspondentes.

A proliferação dos correspondentes bancários serve apenas aos interesses dos bancos em terceirizar mão-de-obra, se livrar de empregados de atividades mais rotineiras e simples e reduzir custos. E a redução de custos é aviltante. Grijalbo Fernandes Coutinho (2011, p. 135) mostra um quadro comparativo o demonstrando.

Em 2009, o piso salarial dos bancários (escriturário) era de $\mathrm{R} \$ 1.010,64$, enquanto que o dos correspondentes era de $\mathrm{R} \$ 550,00$, ou seja, a metade. A jornada de trabalho dos bancários era de $6 \mathrm{~h}$ ao passo que os correspondentes trabalhavam, em média, 9h48min diários. O vale refeição era de $\mathrm{R} \$ 15,80$ dos bancários contra $\mathrm{R} \$ 4,00$ dos correspondentes. Os bancários recebiam PLR de até 2,2 salários mais um adicional de PLR de R \$1.980,00, vale-alimentação mensal de R 272,96 e auxílio-creche de $\mathrm{R}$ \$ 196,18 por mês, direitos esses previstos na convenção coletiva e negados aos correspondentes.

Percebe-se que a terceirização promovida via correspondentes bancários reduz consideravelmente as condições de trabalho de empregados que trabalham para os bancos, mas tem sua condição de bancários negada pela terceirização. A despeito de a figura do correspondente ter surgido ainda na ditadura militar, foi só no século XXI que o problema se expandiu.

Segundo dados da FEBRABAN (2010), entre os anos 2000 e 2010, o número de correspondentes saltou de 13.731 para 165.228, um crescimento exponencial e desproporcional à geração de empregos bancários do período. Somente entre 2009 e 2010, houve um crescimento de 10,5\%. Logo, em 2010, havia 486.196 bancários e 165.228 
correspondentes, sendo que no decênio analisado, a expansão de vagas nos bancos foi de de $25 \%$ ao passo que a expansão dos correspondentes foi de mais de $1000 \%$.

Esses dados mostram que tem havido um crescimento do nível de emprego nos bancos, mas há um crescimento muito maior do nível de emprego fora dos bancos. O setor financeiro está terceirizando brutalmente os seus serviços, reduzindo custos e negando a centenas de milhares de trabalhadores que engrandecem seus lucros condições sociais e econômicas mínimas de trabalho. A categoria bancária é forte e organizada, tendo um dos sindicatos mais representativos do mundo do trabalho e celebra convenções coletivas com uma série de conquistas negadas aos terceirizados tradicionais e, agora, aos correspondentes bancários.

A análise de dados trazidos pela FEBRABAN $(2010,2011)$ indica que as transformações se intensificam. O investimento em inovação tecnológica superou os $R$ \$ 22 bilhões em 2010, crescimento de $15 \%$ em relação ao ano anterior. Do total dos investimentos, $31 \%$ foram gastos com software, $29 \%$ com hardware, $22 \%$ com telecomunicações e $18 \%$ com infraestrutura. Tais montantes indicam aumento de operações bancárias efetuadas pelos clientes à distância, sem presença física nas agências. Entre 2000 e 2010, clientes com acesso à internet banking saíram de 8,3 milhões para 37,8 milhões. As operações bancárias efetuadas pela internet já representam $23 \%$ do total e em contínuo crescimento. No mesmo período, o número de cartões de crédito saiu de 29 milhões para 153 milhões. Em 2010, já havia 178.737 unidades de autoatendimento espalhadas pelo país, ocorrendo um aumento de $43 \%$ dessas unidades em pontos públicos, fora das agências, em relação a 2009. Ainda em 2010, 2,2 milhões de contas já eram acessadas por telefones celulares. O uso de cheques caiu 9\% entre 2009 e 2010.

A economia como um todo cresce, os bancos acumulam mais dinheiro e investem mais em inovação. Isso permite que os clientes possam utilizar os serviços bancários sem ter que recorrer a atendimento humano nas agências, podendo utilizar a internet, telefone, caixas eletrônicas e celulares. Reduz-se a necessidade de deslocamento aos bancos e o uso de papel.

Um gráfico apresentado pela FEBRABAN (2011) dimensiona a origem de todas as operações realizadas no ano de 2010. Apenas 9\% das transações foram feitas nos caixas das agências. $32 \%$ foram por autoatendimento e $23 \%$ foram feitas pela internet. Transações automáticas internas (IOF e outros impostos) foram $16 \%$ e automáticas externas (débito automático, crédito de salário, aposentadoria DOC, TED etc.) foram 5\%. O atendimento 
via correspondentes bancários em estabelecimentos comerciais, correios, lotéricas etc. somou $6 \%$ das operações.

A FEBRABAN destaca, pela importância, os crescimentos das operações por correspondentes e pela internet - essa última, com tendência a se tornar a principal em futuro próximo. $\mathrm{O}$ autoatendimento realizado em postos tem aumentado, enquanto que o realizado nas agências tem diminuído. E a terceirização tem crescido.

Os grandes bancos já terceirizaram 66\% do help desk; 58\% das telecomunicações; 48\% dos serviços de impressão, manutenção de sistemas e fabricação de softwares; $45 \%$ dos projetos; $39 \%$ do body shop; $38 \%$ do backup site; $33 \%$ do processamento de envelopes; $30 \%$ do processamento de documentos; $30 \%$ da infraestrutura de data center; 25\% das redes; e 19\% dos serviços de back office (FEBRABAN, 2011, p. 29).

A estratégia da reestruturação do sistema financeiro é clara. A concentração de capital parece ser inerente ao setor; as privatizações estancaram e os bancos públicos que restaram foram fortalecidos. A inovação tecnológica tem a clara intenção de permitir que as operações bancárias mais rotineiras sejam efetuadas á distância pela clientela, via caixas eletrônicos, internet ou telefones. Os trabalhos mais simples e repetitivos são terceirizados em duas frentes: a terceirização tradicional dos serviços de suporte ao atendimento, mormente retaguarda e manuseio de papéis, e a proliferação dos correspondentes bancários, que representa a terceirização de serviços simplificados de atendimento ao público como abertura de contas e depósitos.

As agências, que concentram 70\% dos empregados dos bancos, assumem uma nova configuração. Tornam-se postos de busca e atendimento personalizado aos clientes, principalmente os de faixas de renda mais elevadas, verdadeiras lojas dos serviços e produtos dos bancos. Nelas, trabalhadores bancários jovens, de escolaridade elevada e salários mais altos garantem o acúmulo financeiro nos bancos. Cresce em importância e número a figura dos gerentes de venda, de atendimento especializado a pessoas físicas ou jurídicas e, dentre essas, especializados em faixas de renda diferenciadas. Muitos dos gerentes são deslocados exclusivamente para a captação de clientes, os denominados hunters.

As hierarquias cobram intensamente o cumprimento das metas estabelecidas, tornando os bancos verdadeiras panelas de pressão. Cada empregado tem metas a cumprir individualmente, seu grupo tem uma meta coletiva maior, a agência tem uma meta global, a superintendência regional tem a sua própria, a estadual mais outra até que cumpra-se a 
meta nacional do banco. À medida que sobe a hierarquia, cresce os montantes cobrados e a pressão.

Por ser o objeto de trabalho dos bancários virtualizado, dinheiro traduzido em créditos e débitos eletronicamente computados e sem correspondência na economia real, a cobrança é mais intensa. Trabalhadores de uma montadora de automóveis tem o seu trabalho mediado por uma série de elementos materiais que interferem em sua produtividade: a disponibilidade de matéria-prima, a demanda pela compra de veículos, a capacidade de trabalho das máquinas. Para um bancário, é diferente.

Se ele cumpre uma meta de R\$ 100 mil em um mês, no mês seguinte lhe cobrarão R \$ 110 mil. O banco lhe faz acreditar que seu desempenho só depende dele porque todos precisam, em tese, dos serviços bancários e ele deve ter a capacidade de convencer um cliente a adquirir um produto ou serviço que lhe traga dinheiro ao banco e permita a esse valorizá-lo a juros. Mesmo que a pessoa não queira gastar nada, basta abrir uma poupança ou aplicar em títulos e a ciranda financeira funcionará. Uma pessoa que compra um carro precisa do carro e o faz em um espaço de tempo longo; um cliente de banco pode sequer conhecer os serviços disponíveis, basta que um gerente o convença a utilizá-lo e, se ainda não for cliente, basta que abra uma conta no banco, nem a movimente e seu dinheiro já trará lucros.

Essa situação especial da condição bancária propicia que o assédio torne-se um mecanismo de gestão que trará lucros e dividendos aos bancos e problemas físicos e psíquicos aos bancários.

\subsection{O Assédio Organizacional nos Bancos}

Para manter esse novo bancário vendedor organizado em acordo aos objetivos dos bancos, estes se utilizam de técnicas de gestão de recursos humanos apropriadas. A expansão do setor de serviços trouxe problemas novos e os grandes bancos demonstram que conhecem a questão e se adequaram.

Cada cliente representa uma particularidade e suas demandas e possibilidades são únicas. O bancário que lida diretamente com o público conhece os manuais e os comandos que emanam do poder diretivo, mas estes elementos serão sempre insuficientes, dependem 
das respostas dados pelo cliente. "Há a responsabilidade de realizar a tarefa nas suas intenções mais do que nas suas prescrições, manter o controle sobre as finalidades mais do que sobre os processos" (HUBAULT, 2011, p. 125).

Os bancos não tem o controle total de sua atividade econômica porque depende muito do que o cliente pretende. De certa forma, o cliente atua horizontalmente, ele é parte na produção de valor para o banco, tão protagonista quanto. $\mathrm{O}$ bancário que o atende, então, depende de sua capacidade relacional para conseguir o máximo possível.

A mobilização intersubjetiva entre o cliente e o bancário faz parte do processo produtivo dos bancos. Em tal situação, o trabalho prescrito pela empresa, aqueles padrões de conduta detalhados em manuais voltados aos empregados, tem alguma importância mas não tem toda a importância porque boa parte da relação não está prescrita, é imprevisível. O conteúdo do trabalho bancário é promover a interação rentável entre o banco e seus produtos/serviços e o cliente e sua demanda/possibilidade. Cabe ao empregado localizar a individualidade do cliente na generalidade do banco e vice-versa.

François Hubault sugere que deve se reconhecer que a subjetividade é alçada a valor econômico nas relações de serviço em geral e nos bancos em particular. As dimensões imateriais dessas atividades econômicas trariam problemáticas novas para a gestão dos recursos humanos. Primeiro porque é impossível reduzir as subjetividades a um valor contábil mensurável; segundo porque a empresa não consegue controlar o trabalho por completo na medida que a prescrição do comportamento do empregado torna-se impotente diante da imprevisibilidade do cliente.

Se esta relação intersubjetiva não for adequadamente ajustada, dois problemas opostos podem ocorrer. Um tratamento injusto da perspectiva do cliente, porque um banco não oferece o mesmo serviço a todos, mas um serviço adaptado a cada um. Lado outro, a sujeição do bancário ao cliente pode configurar verdadeira situação de assédio porque este último vai à agência com sua demanda criada pela publicidade e exige tratamento diferenciado que o fidelize. Deve-se lembrar que o bancário está só no trato com o público e todas as decisões que toma impacta na empresa.

O banco deposita no bancário toda a responsabilidade na venda. É por isso que busca empregados com senso de iniciativa, de responsabilidade, pró-ativo, porque os seus lucros são gerados, em grande parte, na relação personalizada travada com sua clientela. $\mathrm{O}$ bancário deve convencer o cliente com os meios (imateriais) que dispõe, deve compreender quem é o cliente e o que ele busca sabendo que não há manual que o diga. 
Hubault destaca que essa é a singularidade da relação de serviço.

O que a distingue do ponto de vista econômico é o lugar que é ocupado pelo engajamento da subjetividade para julgar corretamente, em seguida desenvolver, as condições da atividade do destinatário que constitui por fim o desafio da oferta (HUBAULT, 2011, p. 134).

É muito mais simples o controle do trabalho em uma fábrica. Têm-se as máquinas e as matérias primas no interior da empresa e esta dá o comando do que deve fazer cada empregado. Em um banco, isso não é tão simples porque o cliente é parte da atividade econômica; a ação que resultará em lucro ao banco não é decidida internamente, mas sim de forma relacional.

Como o banco precisa controlar e avaliar de alguma forma o trabalho dos bancários, faz não da forma adequada, mas da forma que ele consegue calcada no seu direito de propriedade e na relação subordinante que mantem com o seu empregado. Por isso, os bancos se utilizam de métodos de cooptação dos bancários e de avaliações "quantofrênicas" que redundam em assédio moral organizacional, com graves consequências para a saúde física e psíquica destes empregados.

Conhecer as técnicas de mobilização subjetiva do trabalho bancário e de sua avaliação pelo sistema de metas é fundamental para compreender como desenvolve-se o assédio organizacional nos bancos.

3.3.1 A base subjetiva do assédio moral organizacional nos bancos

As peculiaridades do trabalho bancário fazem com que os bancos busquem sempre a motivação dos empregados para o desempenho de seu labor. A subjetividade do bancário vendedor é crucial para o sucesso da empresa e esta subjetividade deve ser devidamente manipulada para que cada empregado sinta-se integrado em propósitos com o banco. O ego de cada um deve compor um grande ego da empresa. 
Para manter essa mobilização permanente, surgiram técnicas de gestão que visam adaptar-se ao setor de serviços. Duas são muito utilizadas pelos bancos: o marketing interno e a qualidade total.

A importância do marketing externo, direcionado ao grande público consumidor, sempre teve sua importância reconhecida. Porém, as novas formas de gestão de recursos humanos e as novas "culturas empresariais" demandam a produção de um marketing interno voltado aos empregados. Estes devem ser fidelizados pelo empregador, devem crer que seu trabalho é valorizado e que a empresa deseja a sua permanência.

Vende-se o próprio banco aos bancários. Os trabalhadores dos bancos são permanentemente convencidos de que estão no emprego certo e que não há outro lugar para eles. Onde estão é onde poderão desenvolver suas habilidades e terão a chance de ascender profissionalmente. "Procura-se criar nos trabalhadores os ideais de sua vida projetados nos ideais da empresa" (REGO, 2011b, p. 68).

Se os bancários são convencidos de que sua realização pessoal dar-se-á no banco em que trabalha, engaja-se com mais comprometimento ao seu labor, almejando um posto maior na hierarquia. Torna-se mais produtivo, aumentando o nível do seu desempenho. $\mathrm{O}$ banco sabe que suas normas e orientações internas são insuficientes para um bom desempenho dos seus empregados e trabalha sua imagem visando convencê-los.

Via de regra, são as grandes empresas que aparecem nos rankings elaborados pela mídia especializada sobre "as melhores empresas para se trabalhar". Para uma grande corporação, são importantes essas aparições públicas de forma a despertar o interesse dos empregados dos bancos concorrentes e fazer com que os seus empregados sintam-se valorizados e desejem a permanência.

Nesse ínterim, os grandes bancos e a FEBRABAN divulgam ao máximo os direitos constantes na convenção coletiva nacional dos bancários. Esses direitos deixam de ser conquistas dos trabalhadores arrancadas à revelia dos empregadores e passam a ser utilizadas como instrumento de marketing dos bancos, que resistem ao máximo em não conceder nenhum direito.

A estratégia de autodivulgação baseia-se nos benefícios da categoria e na possibilidade de ascensão na carreira do banco. Estes elementos ocultam as condições reais de trabalho da categoria e o sofrimento a que os bancários são submetidos cotidianamente. Essas condições é que deveriam servir de base aos rankings, ao invés de questões que passam ao largo do conteúdo real do trabalho. 
Ascender profissionalmente em um banco é possível, mas é possível apenas a uma minoria ínfima. À medida que sobe-se a hierarquia, diminui o número de funcionário, afunilando os espaços de trabalho que os empregados de base almejam. Trata-se de uma ilusão porque pouquíssimos chegarão lá. De outro lado, cada tópico das convenções coletivas é duramente negociado com a representação sindical patronal. A intransigência dos bancos leva, frequentemente, às greves, ápice do conflito entre o capital e o trabalho nos marcos jurídicos e econômicos do capitalismo.

O outro aspecto da mobilização da subjetividade dos empregados bancários é a busca pela qualidade total.

A gestão da qualidade total tem origens no Japão, particularmente na Toyota. $O$ Japão do pós-guerra dispunha de mão-de-obra e matéria-prima escassas. Era necessário muita disciplina para que houvesse o mínimo de perdas e desperdícios na produção, o que originou técnicas de gestão de recursos humanos concentradas nos processos de trabalho.

Os erros e desperdícios da produção aumentavam os custos do produto final, dificultando a atuação da empresa perante a concorrência. O Toyotismo propôs, então, que houvesse o mínimo de utilização dos materiais, de funcionários e de gestores. Fundamentalmente, o que a qualidade total busca é o acerto sempre, não pode haver erros. Isso aumenta consideravelmente a pressão sobre os empregados, que não podem errar.

O número de empregados é o mais reduzido possível para realizar as tarefas. Desse modo, se alguém faltar ou se atrasar, compromete toda a produtividade da empresa. A realidade dos bancários demonstra que muitos continuam trabalhando mesmo quando adoecem, porque se faltarem prejudicam o seu desempenho e o desempenho da agência.

Baseado na ideia da qualidade total, os bancos planejam minuciosamente a distribuição dos seus empregados. Calculam, por exemplo, quantos caixas devem estar disponíveis para o atendimento ao público nos dias de maior ou menor fluxo de clientes, nos horários de maior ou menor movimento. O problema é que esses cálculos não conseguem prever o futuro e pode ser que haja um movimento maior inesperado ou a ausência de um dos caixas. Qualquer eventualidade aumentará a pressão sobre os bancários e, no mundo dos bancos, as cobranças e reclamações dos superiores hierárquicos não costumam ser nada gentis.

Consequência natural da qualidade total é a manualização exacerbada. Todos os procedimentos que os bancários devem ter estão previstos em algum normativo interno. Para o banco, se algo der errado foi porque o bancário não observou as prescrições porque 
todo o processo foi previamente calculado para não dar errado e aqui reside grave problema.

Conforme já visto, o ato de trabalhar envolve as prescrições de conduta somadas às soluções das inúmeras ocorrências não prescritas. Por mais minucioso que seja o manual, as situações encontradas pelos bancários são imprevisíveis e dependem de decisões não prescritas a serem tomadas pelo trabalhador. Se este seguir os manuais à risca, não conseguirá fazer nada e é por isso que os bancos procuram empregados com grau de escolaridade elevado e capacidade relacional, para que consiga dar boa solução aos imprevistos.

Assim, o conteúdo do trabalho bancário varia entre o prescrito e o imprevisível, com claro predomínio deste último. Se falta um documento simples de um cliente, o bancário tenderá a conceder o crédito mediante as devidas assinaturas e o compromisso do cliente de trazer o documento faltante posteriormente. Ele assim o faz para cumprir com suas metas exigidas pelo banco. Porém, se algum problema houver, o banco o responsabilizará integralmente pelo erro.

O que os bancos fazem, de fato, é vistas grossas aos empregados que descumprem com os manuais mas cumprem os objetivos de venda dos produtos e serviços, porque sabem que é impossível aos seus empregados permanecer todo o tempo atento às prescrições. De outro lado, se algo der errado, a culpa cairá sobre o empregado por ter descumprido as normas impostas, mesmo que o banco saiba que as normas inviabilizam o trabalho em muitos momentos. "É contraditório, mas a Qualidade Total não propicia qualidade. Propicia somente o padrão. Além disso, é um convite à depressão e à angústia, pois o trabalhador é fortemente pressionado a não errar, instalando-se o medo" (REGO, 2011a, p. 85).

Além dessa manualização, os princípios da qualidade total atendem a uma outra função: o de controle ideológico dos trabalhadores.

As novas técnicas gerenciais visam a adesão do bancários às estratégias organizacionais dos bancos, canalizando a energia dos empregados ao cumprimento dos interesses dos empregadores. Através de jornais, revistas, internet, banners e outros mecanismos de comunicação, os bancos propagandeiam suas políticas de mercado e cobram participação, competitividade e compromisso com essa política.

Os bancos divulgam os novos valores fundamentados na concorrência, cada vez mais internacionalizada e acirrada. Se os bancos não oferecerem um serviço de qualidade, 
personalizado, que atenda às melhores expectativas da clientela, sucumbirá à concorrência e os bancários são pressionados a aumentar a sua produtividade e oferecer essa qualidade total nos seus serviços.

Os programas de qualidade total visam "sensibilizar", "educar" os bancários sobre a importância do culto à excelência dos serviços. Nas fábricas, o poder diretivo é suficiente para submeter os trabalhadores ao comando das empresas. Nos bancos, o mercado, a concorrência, os clientes são os atores externos utilizados para pressionar os empregados a melhorar sua produtividade.

Equipes de qualidade total atuam nos bancos colhendo informações dos bancários sobre possíveis melhorias a serem promovidas no trabalho. Obviamente, os bancários contribuem com suas experiências, mas não contribuem com as deliberações decorrentes dessas pesquisas, sempre originadas de baixo pra cima. Os bancos se apropriam do savoir faire de seus empregados para utilizar contra eles mesmos porque, a partir dessas consultas, os departamentos de recursos humanos compreendem onde há excessos de funcionários visando cortar despesas e otimizar o rendimento dos empregados.

Para Jair Batista da Silva, é notório o caráter político dos programas de qualidade total implementados pelos bancos.

\footnotetext{
Políticos porque, além de as recorrentes abordagens sobre qualidade estarem circunscritas à lógica da produção e ao consumo de mercadorias e serviços (portanto da qualidade dos produtos e do trabalho nas empresas), objetivam criar, antes de mais nada, uma identidade de interesses entre trabalhadores e empresas e propagar uma imagem de harmonia no ambiente de trabalho (SILVA, 2009, p. 208).
}

Os programas falam em mudança de comportamento no trabalho, atitude, nova cultura empresarial, participação e engajamento. Buscam a identificação do trabalho para com o capital e aumentam a pressão por prestação de serviços de excelência. Este culto à excelência nos serviços só será possível com a adesão total do bancário com o banco e com a eliminação do senso crítico e da resistência.

Segundo Silva (2009, p. 210), essas práticas foram introduzidas pelos bancos estrangeiros que ingressaram no Brasil com a abertura econômica promovida já no início da década de 1990. A partir disso, a FEBRABAN incumbiu-se de dissemina-las. No início, preconizava a resolução dos problemas gerados pelas grandes filas e insuficiência de 
empregados para atender o público. Depois, pugnou-se pela reestruturação do funcionamento dos bancos, divisão das agências, especialização dos serviços e segmentação da clientela, originando os métodos adotados pelos bancos atualmente.

Some-se a essas técnicas "positivas" a mobilização pela negatividade que, obviamente, não consta nos manuais. Os bancários trabalham todo o tempo à base do medo. Medo de perder o emprego, medo de ser descomissionado, medo de ficar nas últimas colocações nos rankings, medo de ser humilhado na frente dos colegas. É muito comum na categoria toda sorte de agressão moral. Palavras ofensivas, insinuações, xingamentos, comparação do desempenho com o de seus pares. O assédio interpessoal integra-se ao assédio organizacional.

A mobilização subjetiva dos bancários através da propaganda ideológica das estratégias de mercado dos bancos e da busca pela adesão incondicional dos empregados aos empregadores é necessária para facilitar a introdução do que realmente interessa aos bancos: o sistema de metas.

3.3.2 A base objetiva do assédio moral organizacional nos bancos

O cotidiano de um trabalhador bancário é de pressão total. Pressão pelo cumprimento de metas extenuantes, pressão para que preste um serviço de excelência, pressão pelo medo de ser dispensado, pressão para conseguir uma promoção na hierarquia do banco, pressão pelas exigências dos clientes.

A categoria bancária chegou a ter mais de 800 mil empregados há duas décadas e encontra-se atualmente com pouco mais de 500 mil. Não obstante, o lucro dos bancos cresceu incessantemente no período, sempre em índices muito superiores ao crescimento do PIB e dos outros setores da economia.

Logo, o nível de produtividade do trabalhador bancário só aumenta ano a ano; um bancário atualmente representa lucros muito maiores ao seu banco do que nos anos passados. A inovação tecnológica intensificada a partir da década de 90, ao invés de suavizar o labor bancário, intensificou-o, tornando-o mais produtivo.

Segundo o DIEESE (2011a), entre 2010 e 2011, houve uma expansão de 2,8\% do emprego nos cinco maiores bancos do país, ao passo que o lucro líquido dos cinco cresceu 
9,8\% e os ativos totais cresceram 18,1\%, comprovando que a produtividade dos empregados bancários só cresce anualmente. No período analisado, a economia do país cresceu $2,7 \%$, bem menos do que o sistema bancário.

Para manter os níveis ascendentes de lucratividade de seus empregados, os bancos se utilizam de estratégias de gestão que a) mantenham-nos permanentemente motivados, mobilizados para o trabalho e b) mantem um controle severo sobre a produtividade de todos e de cada um, através de instrumentos de avaliação de desempenho baseados nos resultados obtidos.

Os bancos estabelecem metas de desempenho individuais e coletivas de forma unilateral e vertical, e a cobrança rigorosa pelo seu cumprimento é medida que se impõe. A diretoria cobra da superintendência regional, a superintendência cobra das agências, as agências cobram de suas equipes até que estas cobrem de seus funcionários.

Os bancos constroem um quadro de cobranças, competição, rivalidade, visando manter a produtividade dos seus empregados alta e causando-lhes uma série de transtornos morais, físicos e psíquicos. A implementação de mecanismos de remuneração variável atrela o pagamento dos empregados ao seu desempenho e ao de sua agência. Prêmios são concedidos aos mais produtivos, estimulando uma intensa competição cujos beneficiários são os bancos e os prejudicados, os bancários.

Rankings com pontuações baseadas em produtividade são divulgados, constrangendo os de mais baixa colocação e estimulando todos a aumentar o seu desempenho. Cobranças públicas e aviltantes pelos superiores são ordinárias nas agências; se o bancário atinge sua meta, não é elogiado, mas se não atinge, é severamente repreendido e humilhado perante seus pares.

Ao distribuir as metas de desempenhos, os bancos criam um ambiente de competitividade acirrada no ambiente de trabalho. Cada bancário torna-se um rival de seu colega na luta pelo topo do ranking, que lhe garantirá premiações. Além disso, há a disputa entre as agências para ver quem vende mais, disputas entre superintendências regionais e assim por diante. Em todas as esferas dos bancos, trava-se uma disputa feroz por clientela e lucros.

Para incrementar a concorrência interna, em detrimento inclusive do Direito do Trabalho, divulgam-se rankings com a pontuação dos empregados nas agências, apontando um vencedor a ser premiado e vários perdedores a serem repreendidos. Isso dá publicidade 
à disputa e os bancários são pressionados diuturnamente para vender mais que o seu colega.

À medida que sobe-se na hierarquia, aumenta os montantes das metas e a pressão, que recai sobre os subordinados. Quando saem os rankings, todo tipo de impropério é proferido pelos chefes à sua equipe. Trabalhadores são constrangidos, chamados de incompetentes, preguiçosos, tartarugas. Muitos pagam prendas humilhantes pelo mal desempenho ou são ameaçados de demissão.

A prioridade dos bancos não é com um ambiente de trabalho saudável ou com a qualidade de vida de seus empregados. O foco são os resultados obtidos custe o que custar. Dissemina-se uma política onde os fins justificam os meios para atingir as metas, valendo mentir para um cliente ou realizar operações de segurança duvidosa.

Para cumprir as metas impostas, bancários trabalham muito além da jornada legal, suprimem seu horário de almoço, transformam seus ambientes sociais ou familiares em oportunidades de vendas. Saem do trabalho extenuados pelo trabalho massacrante e já preocupados com o dia seguinte. A cobrança é ríspida e diária, não há um dia sequer de alívio das pressões.

A categoria é uma das que mais sofre problemas de saúde e muitos desenvolvem sequelas permanentes. $\mathrm{O}$ mecanismo de avaliação de desempenho pelo cumprimento de metas é reconhecido como o elemento mais importante para o desencadeamento das moléstias adquiridas pela categoria. "O sistema de cumprimento de metas (principalmente para vendas de produtos financeiros aos clientes) aparece como o grande vilão entre fontes causadoras de estresse e adoecimento" (BRUNO, 2011, p. 25).

Os bancos utilizam esse sistema de avaliação de desempenho por ser o mais fácil, mesmo sabendo ser o mais danoso aos empregados. Na qualidade de relação de serviços, o trabalho bancário não deveria ser avaliado por metas porque há muitas variáveis envolvidas na execução da atividade que fogem ao controle dos empregados.

A produtividade dos empregados é um conceito que compara a quantidade de trabalho realizado à quantidade de produção desenvolvida. Em uma indústria é mais fácil dimensionar porque há uma produção palpável, mensurável, que permite medir a produtividade do trabalho. Ocorre que há desafios novos para as ciências econômicas no que diz respeito à produtividade em relações de serviço.

Uma relação de serviço pressupõe a mobilização da inteligência e capacidade relacional do empregado e a associação dessa à relação com o cliente sob uma perspectiva 
econômica, produtiva. "A subjetividade do prestador é diretamente engajada no espaço relacional, sob uma exigência de ordem econômica. O econômico e o subjetivo são, assim, intrinsecamente ligados" (TERTRE, 2011, p. 67).

Christin Du Tertre tira duas conclusões daí. Primeiro, a atividade bancária demanda trabalho imaterial que não pode ser mensurável como um trabalho material. Segundo, há uma participação do cliente no resultado da atividade econômica, sendo este uma espécie de "coprodutor" da valorização econômica. E não é só.

O bancário torna-se um árbitro entre três injunções: a oferta de serviços genéricos pelos bancos com objetivos e procedimentos prescritos, a expectativa gerada pela oferta genérica no cliente e a representação que o próprio bancário tem sobre o seu trabalho. $\mathrm{O}$ empregado deve arbitrar sobre essas três injunções, e ele o faz, o decide sozinho, tendo a responsabilidade de obter sucesso na relação.

Ocorre que essa atuação do trabalhador demonstra haver discrepância entre o ofertado pelo banco e o serviço efetivamente realizado. Para que este serviço realizado submeta-se a uma avaliação, esta deveria levar em consideração "as condições em que os diferentes tipos autores se engajaram". Como os bancos baseiam a avaliação tão somente no resultado obtido pelo empregado, sem considerar os outros elementos envolvidos, o sistema de avaliação pelo cumprimento das metas não "avalia" de fato o desempenho do empregado e torna-se injusto para com este. “A avaliação é desprovida de sentido à luz da profissionalização das equipes e das pessoas. Ela se volta contra os assalariados como pessoas" (TERTRE, 2011, 69).

Avaliação de desempenho de empregados não é nunca uma tarefa fácil. Os mecanismos clássicos sempre se basearam em trabalho industrial e a expansão do setor de serviços traz novas reflexões aos profissionais que atuam na área. Além disso, os economistas do trabalho americanos afirmam que uma avaliação precisa demandaria tempo e dinheiro das empresas.

O que os bancos fazem é lavar as mãos Ao invés de se preocuparem em estudar e desenvolver bons programas de avaliação, optam pelo mecanismo mais simples: distribuem metas a serem cumpridas pelos bancários e avaliam o desempenho destes comparando os resultados obtidos com as metas prescritas. Isso mantem os trabalhadores permanentemente mobilizados ao labor porque de seu desempenho depende a sua remuneração (variável) e a suas possibilidades de ser promovido ou dispensado. 
A especificidade da relação de serviço demanda três atitudes sobre análise de produtividade segundo Tertre. A primeira é o que os bancos fazem: ignorar as peculiaridades do serviço e atentar-se exclusivamente aos efeitos mensuráveis - a quantidade de clientes atendidos, de contas abertas, de créditos concedidos, de aplicações negociadas etc. Essa opção ignora as dimensões subjetivas deste tipo de trabalho e direciona todo o peso dos resultados aos empregados, intensificando o trabalho e adoecendo os empregados.

A segunda atitude seria a de análise "multicritérios", que separaria o mensurável do imensurável, mas seria insuficiente por não preocupar-se com os fundamentos da produtividade do imaterial. A terceira, que seria a correta, compreenderia a relação de serviço como um "construto social" não captada diretamente pelas técnicas atuais de gestão de recursos humanos. Teria o mérito de observar o trabalho como coletivo e apreender a racionalidade pela relação entre o bancário e o cliente.

Ao contrário disso, os bancos utilizam critérios de aferição de produtividade impertinentes com duas características. A primeira é isolar um dos fatores presentes no setor de serviços e medir o resultado final da produção por este fator isolado, em uma relação de causa e efeito simples. A segunda diria respeito a duas funções desse modelo: de previsão, estimando os ganhos almejados, e de controle, verificando esses ganhos.

A opção por esse modelo teria finalidades de fácil identificação. "Efetivamente, a escolha de indicadores de produtividade não é neutra. Ela induz a uma concepção de racionalização da produção e, nesta, do lugar destinado ao trabalho" (TERTRE, 2011, p. 74). Esse lugar destinado ao trabalho é óbvio: o banco responsabiliza integralmente seus empregados pelos resultados obtidos.

Não importa se o cliente passa por uma situação difícil, se o território de atuação da agência é mais ou menos populoso, se o bancário está com problemas pessoais. O que importa é o cumprimento das metas pré-estabelecidas de forma objetiva. Como há uma boa dose de imaterialidade no labor bancário, o banco atem-se à única forma disponível de analisar os seus empregados uniformemente: reduzindo-os a números, a resultados palpáveis e comparáveis.

O caráter político desse sistema avaliativo e seus impactos negativos não passam despercebidos por Ana Magnólia Mendes e Luciane Araújo. Segundo as autoras, esse tipo de avaliação por metas baseia-se na ideologia propagada da excelência e em pressupostos 
individualistas, onde a responsabilidade pela qualidade e quantidade do trabalho cai sobre os ombros de cada empregado.

As metas afirmam a hegemonia da organização sobre os bancários, e a diversidade destes não encontra espaço para manifestar-se. Prevalecem os interesses dos bancos em detrimento da saúde dos bancários.

\begin{abstract}
A relação entre sofrimento, patologias e processos de avaliação é perpassada pelas pressões que algumas culturas impõem ao trabalhador, levando- a uma adaptação ao prescrito, mas provavelmente à custa de muito sofrimento em ter de se ajustar a determinados parâmetros de performances exigidos pela organização (MENDES, ARAÚJO, 2011, p. 91).
\end{abstract}

As autoras creem que, nesse ambiente de condutas e metas prescritas, predominam uma "personalidade objetiva" vinculada à ciência, à técnica, à racionalidade das exigências de lucratividade dos bancos. Essa personalidade objetiva conduz a atitudes passivas e reativas, em detrimento de comportamentos autônomos que não aceitariam o assédio organizacional com seus métodos de trabalho desumanos e as moléstias desenvolvidas.

A padronização do trabalho prevista nos manuais atuaria em detrimento da liberdade e da criatividade dos empregados. O bancário desprovido de sua subjetividade plena sente-se como um robô ou um super-herói que não pode errar, não pode dar menos do que o banco cobra. Ao exigir excelência no atendimento ao cliente e distribuir metas de desempenho, o banco introjeta no trabalhador a pressão pela produtividade do trabalho.

Como nada é tão ruim que não possa piorar, os bancos aderiram ao pagamento de remunerações variáveis aos seus funcionários. A partir da reestruturação produtiva dos anos 90, os bancos passaram a pagar um valor fixo aos empregados e um valor variável, relacionado ao desempenho dos bancários.

Essa nova estratégia visa individualizar os salários de acordo com a produtividade de cada um. Num mesmo banco, poderá haver empregados recebendo salários díspares entre si, acirrando a competitividade no seio da categoria e quebrando laços de solidariedade para resistir à intensificação do trabalho por pressão.

A remuneração variável aumenta a exploração do trabalho porque se utiliza de estímulos ao aumento da produtividade e intensificação do trabalho através de abonos e prêmios vinculados ao desempenho e não incorporados ao salário base. 
Assim, se a remuneração variável implica para os trabalhadores a intensificação do trabalho e a perda de direitos salariais, para as empresas permite expressiva redução de custos com força de trabalho e elevação dos níveis de produtividade (JINKINGS, 2011, p. 158).

Pela adesão à ideologia patronal, pela disputa por uma promoção na carreira, pelo medo de perder o emprego e pelos ganhos materiais obtidos, o trabalhador bancário é pressionado todo o tempo a cumprir e superar as metas impostas unilateral e verticalmente pelos bancos. Isso aumenta sua jornada de trabalho, diminui ou impede o horário de repouso, mantem o seu controle psíquico pelo banco, fragiliza seu corpo e sua mente e leva ao adoecimento.

As metas e a consequente remuneração variável põem a responsabilidade pelo desempenho da empresa no trabalhador. Se este vai bem, a empresa vai bem e o compensa com uma remuneração maior. Ao contrário, se o empregado não cumpre com suas metas, é penalizado pela remuneração variável e pelas ofensas públicas que ouvirá de seu chefe, igualmente pressionado a atingir metas.

$\mathrm{O}$ assédio moral organizacional nos bancos é fundamentado em mecanismos de gestão de recursos humanos que incentivam o individualismo e competição, controlam ideologicamente os trabalhadores, prescrevem rigidamente o comportamento e avaliam os bancários pelo cumprimento de suas metas e redução do tempo de atendimento aos clientes. O resultado desse ambiente de trabalho distorcido é que os empregados se veem obrigados a forçar ao máximo seu corpo e sua mente para cumprir suas obrigações, muitas vezes extrapolando seus limites e ocasionando doenças.

Além de moléstias físicas e psíquicas geradas pela gestão por stress característica dos bancos, os trabalhadores são pressionados a molestar também a sua própria moral. $\mathrm{O}$ seu papel é de agregar valor ao cliente, compreendendo cada caso para que se chegue a uma solução melhor possível e vendendo-lhe os produtos adequados a suas expectativas e demandas. Porém, nem sempre isso ocorre dentro de uma normalidade ética.

Os trabalhadores bancários são pressionados diariamente a superar seus limites de venda. Sua remuneração depende de seu desempenho, assim como seu progresso na carreira e sua relação com seu superior hierárquico. Com o intuito de bater suas metas e não ser agredido por seu chefe, muitas vezes, o bancário entra em conflito ético consigo ao não passar as informações corretamente aos clientes para facilitar a venda de um produto 
ou serviço, mesmo que não seja o adequado ao cliente. "O cliente não quer comprar, não pode comprar, não precisa comprar o que é oferecido, mas o bancário é obrigado a vender, o que leva a sérios conflitos éticos e morais" (BRUNO, 2011, p. 25).

Walcir Previtale Bruno (2011, p. 25) cita uma pesquisa realizada com 9 mil bancários feita pelo Sindicato dos Bancários de São Paulo, Osasco e região em 2010. 60\% dos caixas relataram sentir que enganam os clientes ao vender-lhes produtos e serviços, assim como $45 \%$ dos gerentes. No total, $44 \%$ dos bancários declararam o mesmo.

Isso mostra que as práticas assediantes exercidas pelos bancos prejudicam principalmente os seus trabalhadores que vivem uma vida de stress permanente $\mathrm{e}$ adoecimento, mas prejudicam também os clientes, vítimas que são da pressão exercida para que se cumpram as metas.

Este trabalho contou com o depoimento em caráter sigiloso de três gestores de hierarquias elevadas de bancos públicos e privados com o intuito de compreender como funciona o sistema de avaliação e metas. Em linhas gerais, foi dito que as metas representam $80 \%$ da avaliação e que há métodos subjetivos que correspondem aos outros 20\%. Ou seja, há espaço para avaliações subjetivas dos gestores, mas o desempenho do bancário é fundamentalmente determinado pela sua produtividade. Eventuais dificuldades serão localizadas nos $20 \%$, o implica dizer que não há muita consideração por erros ou ausências, mesmo que previdenciárias.

Segundo foi relatado, as metas são elaboradas a partir da expectativa do crescimento econômico, do locus de atuação da agência e dos desempenhos anteriores dos empregados e das agências. Os bancos privados privilegiam os empregados high performance, aqueles em torno de $25 \%$ de melhor desempenho, que recebem viagens, prêmios e podem até dobrar o seu salário pela remuneração variável. São realizadas campanhas de venda, normalmente trimestrais ou quadrimestrais, para estimular o aumento do desempenho.

Percebe-se claramente que os sistemas de avaliação de desempenho adotados pelos bancos servem não para efetivamente avaliar, mas para manter a mobilização constante dos empregados. Se um bancário contata dez clientes em um dia, mas nenhum dispõe-se a adquirir um novo produto, seu desempenho é zero para o banco. Se outro contata apenas um cliente e lhe vende qualquer quantia, seu desempenho será melhor do que o anterior.

Conforme já observado, o conteúdo do trabalho bancário envolve o cumprimento dos procedimentos prescritos pelos bancos associado à execução de tarefas imprevistas, 
que não cabem nos manuais de conduta. No trabalho em banco, ocorrem muitos imprevistos, anormalidades, excepcionalidades, problemas que não podem ser previstos. E o bancário tem que ter a capacidade de compreender o problema e resolvê-lo sozinho, sem o apoio do banco que não previu a situação.

Pode-se dizer, então, que o conteúdo do trabalho em banco envolve as atividades prescritas e as não prescritas. O bancário afasta-se das prescrições todo o tempo e retorna quando é possível. Porém, quando o banco avalia o seu trabalho, não avalia a totalidade das tarefas executadas; avalia tão somente aquilo que é visível, quantificável, mensurável, aquilo que é passível de ser traduzido em indicadores matemáticos de desempenho.

O trabalho real é desconsiderado pelos bancos e somente o quantificável é reconhecido pela organização. O banco vê o bancário exclusivamente pelos valores que este consegue acumular com as vendas dos produtos e serviços, cada empregado é reduzido a um número e os que alcançarem a maior lucratividade será melhor remunerado, premiado ou promovido, enquanto os que atingirem lucros menores são repreendidos e ameaçados de dispensa caso não melhorem seu desempenho.

As metas são o mecanismo utilizado para manter os trabalhadores mais e mais produtivos através do medo. Os bancários trabalham com medo de ficarem nas colocações mais baixas dos rankings e serem considerados incompetentes para o trabalho. Há ainda o medo de que os seus adversários, que deveriam ser apenas colegas, percebam seus sinais de fraqueza e se motivem a superá-lo. Há, então, medo da organização e medo dos outros trabalhadores.

O trabalho bancário é organizado da forma mais individualizada possível. Quando um caixa, um gerente, um atendente do call center atendem um cliente, o fazem em total isolamento em relação aos seus colegas e são estimulados a provar que são capazes de se superar e que são suficientes para cumprir todos os objetivos impostos pelos bancos.

Em uma fabrica, há um sentimento de coletividade maior porque a tarefa de um depende da tarefa do empregado anterior e é pré-requisito para a tarefa do empregado seguinte. É fácil observar isso em uma linha de montagem, onde o trabalho de cada empregado relaciona-se com o trabalho dos outros.

Os bancários trabalham isoladamente e são avaliados isoladamente. Cada indivíduo é o único responsável pelo seu desempenho e progredir ou ser excluído é sua responsabilidade individual. Se o capital bancário é o capital por excelência, o trabalho bancário também pode ser considerado o trabalho por excelência porque mantem o foco do 
desempenho no indivíduo, responsabilizando-o pelas consequências em sua carreira. $\mathrm{O}$ banco não promove ou dispensa ninguém, são os bancários que alcançam a promoção com os seus próprios esforços ou é eliminado por sua deficiência. $\mathrm{O}$ darwinismo social é levado às últimas consequências!

O clima de competição generalizada torna os trabalhadores mais dóceis e submissos à hierarquia. Além disso, desenvolvem o individualismo que atenta contra o coletivismo ou associativismo, bases da construção de um sindicato forte que enfrente os desmandos do capital sobre o trabalho. Como um empregado não depende do outro em seu labor, dificulta-se a união que questione o modelo de gestão vigente.

3.3.3 Decorrências do assédio moral organizacional no setor bancário

Os impactos do trabalho na saúde dos trabalhadores é estudado desde a idade antiga grega e romana. Com o advento do capitalismo e a disseminação do trabalho assalariado, tais estudos ganharam força a partir do século XVIII na Itália e se desenvolveram com mais intensidade no século XX.

No Brasil, o fim da ditadura iniciada em 1964 trouxe liberdades sufocadas por mais de vinte anos. A livre expressão do pensamento impactou também a academia, os sindicatos e outras entidades preocupadas com a qualidade do trabalho no país e suas consequências na saúde dos empregados.

Os estudos sobre as Lesões por Esforço Repetitivo (LER) despertou interesse da comunidade científica nacional, após diversas denúncias públicas e coletivas feitas pelos sindicatos. Parecia que o país vivia uma epidemia de LER; a moléstia assolava empregados dos mais diversos ramos da economia e demandava estudos que habilitassem a prevenção e o combate ao mal. Na década de 90, o Governo Federal trouxe a denominação Distúrbios Osteomusculares Relacionados ao Trabalho (DORT) e, desde então, tem-se designado o problema comumente de LER/DORT.

Com as transformações estruturais vivenciados pelo sistema financeiro a partir dos anos 1990, a categoria bancária passou a sofrer mais intensamente diversos problemas de saúde, o que ocasionou uma série de estudos direcionados ao trabalho em bancos. Este trabalho contou com estudos desenvolvidos por juristas, médicos, psicólogos, engenheiros, 
dentre outras especializações, além de material desenvolvido pelo próprio movimento sindical bancário, protagonista da luta em defesa de melhores condições de trabalho.

Os trabalhos desenvolvidos são unânimes em afirmar que as lesões causadas à saúde dos trabalhadores bancários tem origem não só em problemas físicos, mas também relativos aos mecanismos de gestão de recursos humanos utilizados pelos bancos. Analisando o histórico dos estudos científicos relacionados à temática, Maria Maeno observa que "embora muitos insistissem nas causas centradas no mobiliário inadequado, era cada vez maior o número de estudos que evidenciavam os aspectos de organização do trabalho e dos métodos gerenciais como desencadeantes e agravantes das LER" (MAENO, 2011, p. 209). Os elementos evidenciados sempre eram os mesmos: pressão por aumento de produtividade e cumprimento de metas, redução da autonomia das funções, ambiente de intensa competitividade e pouca solidariedade, medo da dispensa e de isolamento dentre outros.

Muitos profissionais tentaram negar o óbvio ao atribuir a quantidade de trabalhadores com problemas de saúde a "simulações" ou a neuroses e outros transtornos psíquicos que levaria os trabalhadores a imaginar uma dor que não existiria. Nenhum estudo científico conseguiu provar essas teses patronais e todos os estudos apontavam as condições objetivas e organizacionais do trabalho como causadores das doenças.

Inicialmente, os problemas mais facilmente verificáveis eram de natureza física, corporal. Nesse aspecto, caixas, empregados da compensação de cheques e manuseio de documentos e atendentes de telemarketing eram os casos mais notórios.

Os caixas passam todo o expediente digitando freneticamente com uma mão e passando documentos em uma máquina com a outra. Por estarem em contato direto com os clientes, que nem sempre os tratam com urbanidade, sofrem pressão externa e interna porque os bancos pressionam para que atendam o máximo de pessoas no menor tempo possível e para que cumpram metas de vendas que não dependem de si mas são-lhe debitada a responsabilidade. Uma pausa para ir ao banheiro é inaceitável nesse ambiente e o repouso legal diário de 15 minutos ou 1 h é letra morta. Todo o trabalho deve ser realizado com a máxima concentração por movimentar vultosas somas diárias e qualquer erro lhe será descontado ilegalmente do salário.

Os empregados da compensação de cheques devem folhear e conferir os valores de cada cheque individualmente com uma mão e soma-los em uma calculadora com a outra. 
O tempo que tem para fazê-lo é curto e o trabalho deveras monótono, repetitivo e tenso pelo medo de errar e pela cobrança dos chefes.

Nos chamados call centers, a disposição dos trabalhadores é bentaniana para que os empregados não conversem entre si e permaneçam todo o tempo observados pelo supervisor. Os procedimentos operacionais são rigorosamente prescritos e até a fala dos atendentes é repetitiva. Há um tempo médio curto para cada atendimento e, se extrapolam esse tempo, são repreendidos pelo supervisor. A digitação também aqui é intensa.

A pressão exercida, a intensidade do trabalho e o grau de monotonia e repetitividade acarretam uma série de lesões, mormente nos tendões, músculos e nervos, além de problemas de coluna ocasionados pelo tempo que passam na mesma postura.

A reestruturação produtiva do setor bancário calcada em prestação de serviços de excelência avaliada pelo cumprimento de metas de desempenho aumentou radicalmente a pressão sobre a categoria. A carga mental utilizada aumentou, assim como o controle ideológico do trabalhador e a exigência por qualificação. Abriu-se espaço para a violência psicológica, humilhações, constrangimentos. O assédio moral é organizacional e mesmo os assédios intersubjetivos são decorrências daquele.

Todos os trabalhadores de banco tem comum a pressão sofrida referente ao desempenho do banco. Este desempenho não é a síntese do trabalho de cada um, é a sua soma. Como os trabalhadores bancários são individualmente avaliados e responsabilizados pelo seu desempenho e pressionados a aumentar e superar sua produtividade, todos são passíveis da adoecimento físico e psíquico. Além disso, todos trabalham com computador, o que envolve digitação intensa mesmo entre os que tem atividades mais relacionais.

Atendentes de telemarketing e compensadores de cheques e até mesmo caixas em alguns casos estão sendo cada vez mais terceirizados, o que agrava a situação porque recebem salários mais baixos, menos benefícios e não dispõem de estrutura sindical sólida que os proteja. O que mais cresce na categoria são os gerentes de venda, responsáveis em grande parte pela captação e fidelização da clientela.

Os gerentes de venda também trabalham de forma individual e arcam com a responsabilidade de seu desempenho. São os alvos principais da política de metas e do controle ideológico porque deles depende enormemente o banco.

Muitos são descolados exclusivamente para a captação de novos clientes, os chamados hunters. Os demais são responsáveis pelo atendimento direto dos clientes mais importantes, que compram os diversos produtos e serviços ofertados pelos bancos. São 
divididos em diversos segmentos: há os que atendem pessoas físicas e os que atendem pessoas jurídicas. Entre ambos, dividem-se pela renda dos clientes, das pessoas físicas ou jurídicas de menor poder financeiro aos de maior poder e renda, que recebem o tratamento mais elitizado dos bancos justamente por terem maior quantidade de dinheiro a ser entesourado.

Os gerentes de venda, talvez o maior símbolo do novo perfil do bancário-vendedor, são os que mais sofrem com as novas técnicas de gestão por terem a maior responsabilidade, ao captar e fidelizar os clientes. Em um ambiente de concorrência acirrada entre poucos bancos gigantescos, a competição pela clientela é intensa e o papel destes gerentes se destaca.

Por isso, recebem metas draconianas para abertura de novas contas, venda de consórcios, capitalizações, seguros, planos de previdência e toda a gama de produtos e serviços ofertados pelo mercado financeiro. Tem a escolaridade mais alta e sonham com a perspectiva de crescer na carreira, algo que lhes é mais palatável do que a um caixa por exemplo. Logo, tornam-se o alvo preferencial do convencimento ideológico, da mobilização subjetiva, embora não sejam os únicos.

Essa reestruturação dos bancos resultou na explosão de lesões físicas e psíquicas que estão relacionadas e não podem ser analisadas em separado porque decorrem do mesmo fenômeno. Maria Maeno (2011, p. 220) sugere que "a dor crônica e as afecções musculoesqueléticas e os transtornos psíquicos convivem simbioticamente" afetando a categoria bancária como um todo.

Outra não é a conclusão de Vitor Barros Rego.

Portanto, a LER/DORT é uma doença psíquica, pois a tarefa monótona e a pressão para aumentar o ritmo de produção ajudam para que o trabalhador bloqueie seu pensamento sobre seu trabalho. O sujeito trabalhando sem pensar, também não tem mais a noção dos próprios limites, não percebendo a necessidade das pausas preventivas durante o trabalho, levando à exaustão física dos tendões (REGO, 2011c, p. 183).

Os estudiosos das patologias que acometem os trabalhadores bancários sempre associam as patologias físicas às psíquicas porque as lesões ao corpo e à mente estão relacionadas às condições objetivas e subjetivas do trabalho em banco, caracterizando o assédio moral organizacional à sua inteireza. 
Os empregados são submetidos à pressão intensa tanto por parte do banco, que lhe cobra desempenho super humano, quanto por parte do cliente, que exige um atendimento célere e de qualidade. Como a responsabilidade cai toda sobre o indivíduo, o bancário submete-se a essas condições de trabalho intensificadas e tenta naturalizar a situação. Constrói-se um ambiente onde todos tentam tornar-se super heróis que consigam cumprir as super tarefas que lhe são impostas.

Ocorre que a imposição geral por um trabalho de excelência com metas de desempenho pré-estabelecidas não leva em conta a diversidade, a individualidade dos empregados. Os bancos impõem as metas sem consultar os bancários, sem um espaço de discussão para saber quais são os níveis de desempenho que os empregados suportariam sem ter que entrar em depressão ou desenvolver uma tendinite. $\mathrm{O}$ único e exclusivo parâmetro para os bancos são os lucros que eles podem ganhar, mesmo que para isso destruam o organismo de seus "recursos humanos".

O trabalho é instituição central na vida de qualquer pessoa. É pelo trabalho que as pessoas adquirem sua renda necessária para manter sua existência e a de sua família e é no trabalho que se passa a maior parte do tempo.

Do trabalho depende a qualidade de vida de qualquer um. De outro lado, se o trabalho é um espaço de pressão intensa, cobranças humilhantes e todo tipo de aviltamento, estará criada uma situação de potencial desgaste físico e mental que levarão ao desenvolvimento de toda sorte de patologia e, em última instância, ao suicídio.

O trabalho nos bancos atrai muitas pessoas pela média salarial superior à geral, pela possibilidade de ascensão profissional, por tratar-se de grandes e importantes instituições para a economia. A audiência com trabalhadores bancários sempre revela que eles consideram o trabalho em si positivo; o problema, para esses trabalhadores, é o modo como o trabalho é organizado, são as metas de desempenho abusivas e a pressão permanentemente mantida em níveis insuportáveis.

Valendo-se de uma comparação metafórica, é como se colocassem centenas de jovens em uma piscina e exigissem todos os dias que estes atinjam a velocidade de Michael Phelps e atrelassem sua remuneração ao seu desempenho. Os que não o atingem são humilhados perante os outros. Nadar é uma prática boa e saudável; mas manter tais níveis de cobrança diária, sem dúvida, extenuará a saúde dos nadadores.

Os empregados bancários criam estratégias de defesa para evitar o sofrimento que geram sofrimento e patologias. Buscam negar a realidade massacrante e se adaptar à 
organização de modo a ser reconhecido e promovido. Com isso, perdem a capacidade de denunciar e combater as práticas assediantes e são capturados pelo assédio organizacional.

Negar a dor, tentar se convencer de que o incômodo não tem relação com o trabalho, abdicar de pedir um afastamento previdenciário pelo medo de ser perseguido ao retornar, deixar de realizar pausas para almoço, ir o menos possível ao banheiro ou bebedouro, fazer horas extras após o encerramento do expediente, cumprir docilmente às ordens do chefe mesmo que tenham sido dadas aos gritos. Várias são as estratégias de defesa que lesionam os empregados.

Uma das estratégias diz respeito à autoaceleração dos movimentos para execução das tarefas. Estas são repetitivas, monótonas, sem sentido. Como há uma pressão para que sejam feitas no menor tempo possível e com metas estipuladas, os empregados aceleram os movimentos para abreviar o tempo das tarefas e para obter alguma sensação de satisfação pelo reconhecimento da organização de que o empregado cumpriu com suas metas.

Nesse ínterim, os trabalhadores tem que suprimir sua subjetividade, seus pensamentos. O mero ato de pensar pode ser prejudicial porque pode desviar a atenção da tarefa deveras mecânica, a distração prejudica a produtividade em um trabalho tão repetitivo e simplificado. A prática da autoaceleração dos movimentos físicos implica na supressão dos movimentos psíquicos. "Trata-se de um processo de repressão pulsional que encontra uma via de saída na motricidade” (ROSSI, 2010, p. 386).

O sofrimento psíquico é anterior e relacionado ao físico. O amortecimento dos pensamentos imbrica-se com a LER/DORT. A relação com os clientes e com os chefes impede a manifestação de agressividade pelas tarefas maçantes. Some-se isso à rigidez da postura em contraste com os movimentos dos membros superiores e à pressão por produtividade e tem-se as condições para o adoecimento.

As LER/DORT normalmente são antecedidas por sensações de dor. Uma dor no punho, no braço, no ombro que o empregado não tem como provar que existe, somente quando a lesão se desenvolve. Quando o problema diz respeito à saúde mental, então a situação é agravada.

A preocupação com o cumprimento das metas é uma constante na vida dos bancários. Além de todo o esforço que fazem, é natural sair de uma jornada preocupado com o dia seguinte e não conseguir relaxar nem mesmo em casa. Muitos relatam sonhar com cobranças, com filas, com metas. 
A expectativa gerada quando do ingresso do banco é a de ter conseguido um bom emprego com amplas possibilidades de crescimento profissional na empresa. A realidade do trabalho bancário se impõe. Os que atuam com tarefas mais simples e repetitivas, como caixas e escriturários, acham o labor indigno de sua qualificação. Os de atividade mais relacional, como os gerentes de venda, saturam-se com as inúmeras tentativas de captar ou agradar um cliente que nunca está satisfeito. Esmagados entre o banco e a clientela, todos são mantidos sob pressão intensa que resultará em stress, depressão, suicídio.

Manter-se entre o prescrito e o imprevisível exige cansativa atividade psíquica. A "quantofrenia" que reduz a avaliação ao cumprimento das metas desgasta ainda mais a mente. Se o desempenho de cada um não fosse divulgado, seria mais fácil pois todos tem o seu limite. Mas a publicidade dada aos rankings intensifica a competição. Se o colega ao lado vendeu 200, o bancário não pode vender 100 porque será humilhado publicamente.

A desestabilização mental acarreta diversos problemas à categoria. Dores de cabeça ou nas costas, insônia, falta de apetite, problemas de relacionamento com familiares e amigos, sentimento de culpa, de impotência, desespero, depressão.

Os pesquisadores concluem que os problemas físicos são decorrentes das condições do trabalho (mobiliário, digitação, movimentos etc.) ao passo que os problemas mentais decorrem da organização do trabalho (mobilização subjetiva, metas, avaliação por comparação etc.). Mas reconhecem que os problemas são interligados. Um caixa realiza digitação intensa e prolongada, mas tem que manter-se atento às suas metas e aos valores para não cometer erros, o que ocasiona stress ou depressão. Ao contrário, um gerente tem que manter-se todo o tempo preocupado com sua carteira de clientes, mas utiliza o computador ou telefone simultaneamente a outras tarefas, gerando incômodos osteomusculares.

Pelo volume de empregados bancários acometidos por problemas físicos ou psíquicos, não há como a questão ser ocultada. E há provas de que tanto os bancos quanto o Estado reconhecem a existência do problema.

Em 2001, foi assinado um acordo nacional entre a representação sindical dos bancos e dos bancários de prevenção e acompanhamento dos casos de LER/DORT. Houve a elaboração de cartilhas e de alguns eventos, mas a pressão por produtividade impediu que as recomendações se materializassem nas agências. Em 2010, a categoria bancária conquistou a primeira convenção coletiva do Brasil relativa a assédio moral. Em ambos os 
casos, percebe-se que os bancos reconhecem que existe um problema a prejudicar seus empregados.

Em 2006, o Congresso Nacional aprovou a Lei 11.430 introduzindo o art. 21-A na Lei 8.213/91, cujo caput transcreve-se abaixo:

\begin{abstract}
Art. 21-A. A perícia médica do INSS considerará caracterizada a natureza acidentária da incapacidade quando constatar ocorrência de nexo técnico epidemiológico entre o trabalho e o agravo, decorrente da relação entre a atividade da empresa e a entidade mórbida motivadora da incapacidade elencada na Classificação Internacional de Doenças - CID, em conformidade com o que dispuser o regulamento.
\end{abstract}

A Lei Previdenciária recebeu o acréscimo de um dispositivo chamado Nexo Técnico Epidemiológico (NTEP). Este nada mais é do que uma relação entre uma doença constante na Classificação Internacional de Doenças (CID) e uma determinada atividade econômica constante no Cadastro Nacional de Atividades Econômicas (CNAE).

Por este dispositivo, para se verificar a relação causal entre o trabalho e a doença para que se conceda auxílio-acidente ao empregado, basta analisar a relação entre a CID e a CNAE. Pesquisas estatísticas epidemiológicas apontam que algumas doenças são comuns em algumas atividades econômicas e a consolidação destas estatísticas permitiu o surgimento do NTEP. Esta lei associa mais de oitenta tipos de doenças associadas ao trabalho em banco, entre patologias físicas e mentais. Uma tragédia!

Entre as doenças relacionadas ao trabalho em banco, constam transtornos mentais e comportamentais relacionados ao uso de múltiplas drogas, esquizofrenia, depressão, reação ao stress, transtornos psicóticos, delirantes e bipolares, episódios maníacos, alterações de humor, transtornos de nervos, mononeuropatias dos membros, cifose, lordose, escoliose e outras dorsopatias deformantes, transtornos dos discos cervicais, calcificação e ossificação dos músculos e outros transtornos musculares, sinovite, tenossinovite e outros transtornos nos tendões, dentre outras dezenas de patologias.

Isso significa que o Estado reconhece que as condições e a organização do trabalho bancário estão estruturadas de forma a agredir a saúde psicossomática da categoria bancária. O Poder Executivo e o Poder Legislativo confirmam a existência do assédio moral organizacional ao instituir o NTEP relacionando as diversas doenças supracitadas ao trabalho em banco. O Poder Judiciário capta o fenômeno ao receber milhares de ações 
anualmente a comprovar a existência de uma situação explosiva no setor a demandar sua atuação.

Para que se visualize o impacto da organização do trabalho em banco na saúde física e mental dos bancários, o presente trabalho contou com dados estatísticos extraídos de três pesquisas promovidas por sindicatos de bancários, uma pesquisa oriunda de uma dissertação de mestrado na UNB e três entrevistas individuais realizadas com bancários do ABC. Tem-se, então, análises quantitativas e qualitativas que facilitam a compreensão do objeto deste estudo e confirmam suas premissas.

Em 2006, a CONTRAF e o Sindicato dos Bancários de Pernambuco realizaram uma pesquisa nacional coordenada por especialistas de universidades que envolveu 2.609 bancários de todas as regiões do país. O objetivo da pesquisa era verificar a ocorrência e frequência de atos negativos no ambiente de trabalho em banco, relacioná-los à saúde dos empregados e às características da organização do trabalho, com enfoque particular em questões de raça e gênero. Os bancos analisados eram públicos e privados de todas as regiões do país.

Dos entrevistados, 38,9\% vivenciaram ao menos uma situação constrangedora nos últimos seis meses. As agressões relatadas duravam, em média, 11,13 meses, ocorrendo várias vezes por semana em 51,49\% dos casos e uma vez por semana em $27,86 \%$. As agressões que caracterizariam o assédio moral interpessoal atingiram $8 \%$ dos empregados, média similar a da Europa à época; o assédio sexual verificou-se em 3,87\% dos indivíduos. O superior hierárquico fora apontado como agressor em 63,71\% dos casos e 16,37\% apontaram agressões do superior contra todos. 49,41\% dos entrevistados acreditavam que o agressor tinha consciência das agressões. No que diz respeito ao ambiente organizacional, $38,9 \%$ apontaram excesso de trabalho, 50,52\% falaram em falta de pessoal, $24,26 \%$ indicaram grande competição interna e 19,47\%, horários desrespeitados. Sobre os impactos na saúde, $60,72 \%$ dos entrevistados declararam-se nervoso, tenso ou preocupado, $42,14 \%$ dorme mal, 37,86\% sente-se triste ultimamente, $37,37 \%$ tem dores de cabeça constantes, $36,55 \%$ não sentem mais satisfação com seu trabalho, 36,36\% sente-se cansado todo o tempo, 33,4\% tem sensações desagradáveis no estômago, 31,87\% tem má digestão, $28,59 \%$ assusta-se com facilidade, $26,23 \%$ perdeu o interesse pelas coisas e $21,2 \%$ tem tremores nas mãos.

A segunda pesquisa foi realizada na base do Sindicato dos Bancários de Pelotas e Região, organizada por profissionais da Universidade Federal de Pelotas e da Universidade 
Católica de Pelotas, acompanhada por esta última instituição. Foram entrevistados 502 bancários em uma base estimada em 650 empregados da categoria, totalizando quase $80 \%$ de toda a base. A pesquisa tinha foco em problemas osteomusculares, foi realizada em 2004 e publicados seus dados na Revista Brasileira de Epidemiologia em 2008.

Nesta, 58\% dos entrevistados classificaram seu trabalho como acelerado e $68 \%$ disseram que a organização do trabalho apresentava problemas. $60 \%$ relataram ter sentido dor músculo-esquelética no último ano e $43 \%$ sentiram dor nos últimos sete dias. 19\% tiveram que evitar o trabalho por dores em três ou mais regiões anatômicas, $40 \%$ relacionaram as dores ao trabalho e $39 \%$ sentiam dor sempre em três ou mais regiões anatômicas das dez investigadas.

A terceira pesquisa foi promovida pelo Sindicato dos Bancários de São Paulo, Osasco e Região e realizada pela empresa Acerte Pesquisa e Comunicação entre 2010 e 2011. Foram entrevistados 818 bancários com margem de erro de 3,5\% e intervalo de confiança de $95 \%$, conforme informado.

A pesquisa constatou que a palavra-chave imediatamente associada ao "estado de espírito" é o estresse. $62 \%$ dos entrevistados declararam que as metas em si não são o problema e que o problema é a pressão abusiva para superá-las, 47\% declararam sentir-se apenas "um número" ("se bato as metas, tudo bem"), $42 \%$ tem sobrecarga de trabalho estressante e $41 \%$ trabalham o tempo todo tenso por não poderem errar. Um grave conflito moral foi verificado que prejudica os consumidores: $44 \%$ afirmaram vender produtos que os clientes não precisam e 33\% pedem até "por favor" para o cliente comprar um produto, tudo para bater as metas.

Perguntados se já sofreram assédio moral, “apenas” 24\% responderam que sim; quando apresentados situações que caracterizam o assédio, o número elevou-se para 42\%, o que demonstra desinformação sobre o tema.

$54 \%$ acham que o trabalho em banco gera mais doenças do que em outras profissões. Dentre estes, indagados sobre os motivos, 63\% afirmaram ser o trabalho sobre pressão para o cumprimento das metas que gera doenças, estresse, depressão, frustração e $32 \%$ atribuíram ao estresse da profissão de atender ao público e exigir muito mentalmente. 66\% afirmaram que a organização atual do trabalho bancário gera doenças, destacando, novamente, a pressão pelas metas (64\%) e o trabalho em si $(21 \%)$. Neste item, $13 \%$ atribuíram o adoecimento diretamente ao assédio moral, provavelmente reduzindo este ao assédio interpessoal. 
Relataram espontaneamente ter algum problema de saúde em frequência anormal 34\%; quando apresentados alguns sintomas, esse número saltou para $84 \%$, com destaque para estresse $(65 \%)$, dificuldade para relaxar pela preocupação com o trabalho (52\%), cansaço e fadiga constantes (47\%), dor ou formigamento nos ombros, braços e mãos (40\%), desmotivação (39\%), dores de cabeça constantes (33\%), medo de "perder a cabeça" (31\%), dor de estômago/gastrite nervosa (30\%), dificuldade em dormir (28\%), vontade de chorar sem motivo aparente (28\%), baixa autoestima (26\%) e pressão alta (15\%).

Essa pesquisa é a mais atual sobre o tema, envolve a base do maior sindicato do país que representa quase $25 \%$ da categoria e é focada no assédio organizacional. Porém, os dados mais dramáticos estão relatados na dissertação de mestrado de Marcelo Augusto Finazzi Santos.

O trabalho de Santos relaciona as transformações ocorridas na organização do trabalho bancário com os suicídios na categoria. Santos informa, com dados obtidos pelo Ministério da Saúde, que, entre 1996 e 2005, quando boa parte dessas transformações ocorreu de fato, nada menos do que 181 bancários cometeram suicídio, em uma média de um auto-extermínio a cada vinte dias.

Santos investigou cinco casos individuais em três níveis: ideação, tentativa e fato consumado. Houve uma entrevista com uma bancária que apenas cogitou a possibilidade de matar-se (ideação), com três bancários que tentaram se matar, mas o corpo resistiu à agressão (tentativa) e com o irmão de um bancário que suicidou-se (fato consumado) que trabalhava com o suicida. As entrevistas apresentaram um quadro de degradação física e mental dos entrevistados tendo o trabalho como fator preponderante. Santos observa que o sofrimento relatado tem o trabalho enquanto seu ente protagonista, mas faz questão de frisar que suicídio é um fato deveras complexo para que estabeleça uma relação de causa e efeito.

\footnotetext{
Dessa forma, preferimos afirmar que as experiências negativas relacionadas com a organização do trabalho foi um dos principais fatores que interferiram na decisão dos pesquisados em idealizar, tentar ou consumar o suicídio, fato que ganha destaque pelo motivo de os entrevistados terem relatado espontaneamente as suas experiências, relacionando-as diretamente com as violências do contexto laboral (SANTOS, 2009, p. 183).
} 
O objeto da pesquisa de Santos é o período compreendido entre 1996 e 2005 e os 181 casas relatados pelo Ministério da Saúde, mas ele faz questão de citar outras pesquisas sobre o tema. Uma, de 1998, indica que houve 72 suicídios na categoria entre 1993 e 1995, com uma média de um caso a cada quinze dias. Esse triênio foi um dos mais intensos em dispensas de bancários com a baixa inflacionária causada pelo Plano Real (que impactou mais os bancos do que outros setores) e pelas reformas, mormente relativas a PDV e enxugamento de quadro dos bancos públicos. Uma segunda pesquisa citada de 2006 concluiu que as tentativas superam em dez vezes os suicídios consumados, o que daria uma média de uma tentativa a cada dois dias. Considerando que apenas um terço desses indivíduos recebia assistência médica em serviços de urgência, estima-se que houve uma tentativa de suicídio na categoria por dia durante 13 anos seguidos (1993 - 2005). Um terceiro estudo apontado por Santos indicava que $4,37 \%$ da categoria apresentava ideações suicidas no ano de 2006.

Além das avaliações quantitativas acima apresentadas, este trabalho conta com avaliações qualitativas do impacto do assédio moral organizacional nos bancos baseada em três entrevistas realizadas na sede do Sindicato dos Bancários do ABC. As entrevistas estão gravadas em áudio, envolve uma mulher e dois homens que trabalharam em quatro dos seis maiores bancos e atividade no Brasil. Os nomes citados nos relatos que seguem são fictícios, criados para preservar a identidade dos entrevistados.

A primeira entrevista será denominada Maria, de 45 anos. Trabalha em bancos há vinte anos, atuando em instituições menores que foram compradas por maiores. Entrou como caixa e exercia a função de gerente de vendas de pessoa jurídica em dois dos seis maiores bancos do país quando desenvolveu suas patologias. Maria associa à globalização as mudanças que ocorreram no setor e tornaram o trabalho em banco degradante por dois motivos. Primeiro, pela concentração do setor que reduz a possibilidade de mudar de emprego. Segundo, pela concentração na figura do gerente de atividades de vendas que não eram típicas da função. Maria fala que, antes, as empresas de cartão de crédito enviavam representantes para vender seus produtos e essa função, hoje, é de responsabilidade dos gerentes. Antes, as empresas de consórcio tinham empregados que vendiam os consórcios e, hoje, são os gerentes que o fazem. Citou diversas atividades que foram incorporadas aos gerentes e há metas para tudo: cartão de crédito, vale-alimentação, consórcio, leasing, seguros, abertura de contas; são dezenas os produtos que tem metas próprias. Maria fala que várias dessas vendas não poderiam ser de responsabilidade dos gerentes e cita dois 
exemplos: uma empresa só adquire um leasing se isso estiver em sua estratégia empresarial, mas os gerentes tem que convencer as empresas a adquiri-lo; os gerentes tem metas máximas de clientes com excesso de dívida como se fosse possível obrigar um cliente a pagar seus débitos. Fala que é prática comum os gerentes pagarem dívidas dos clientes com dinheiro próprio para bater as metas porque destas depende sua remuneração variável. Narra que a cobrança é insuportável e que uma pessoa lhe cobrava as contas, outra pessoa lhe cobrava os seguros, outra lhe cobrava os leasings e ela recebia dezenas de e-mails diários de cobrança. Seus chefes cobravam as metas ameaçando demissões ou descomissionamentos e diziam que as reuniões de Provisão de Devedores Duvidosos (PDD) em São Paulo eram "pior que sequestro". Maria conta que todos temiam essas reuniões e ela descobriu porque quando foi à primeira. A reunião começava às $8 \mathrm{~h}$ em São Paulo e havia cerca de 40 gerentes do interior; além do deslocamento, ninguém dormia na véspera por causa da tensão. A reunião estendeu-se por toda a manhã com um diretor humilhando os gerentes por não terem batido todas as metas. Só havia café e água na reunião e, às 14h, ela entendeu porque: o diretor disse que quem não bate metas não merece lanches e teriam que passar seis horas em reunião à base de café e água. Maria conta que uma amiga sua quase desmaiou e ela a levou às pressas a uma lanchonete perto (essa amiga também está afastada pelo INSS). Maria chorou neste momento. Ela relata que começou a ter taquicardias frequentes e foi ao médico. Ficou três dias na UTI porque estava prestes a ter uma parada cardíaca e mais uma semana internada no hospital. Mudou de banco, mas as cobranças não mudaram. Maria começou a ter crises de pânico. Ela via uma loja cliente sua e imaginava que as empresas iam falir e ela seria dispensada. Maria financiou um terreno de $1.000 \mathrm{~m}^{2}$ porque, se fosse dispensada, teria onde plantar alguns vegetais e criar frangos para alimentar seu filho. Começou a tomar antidepressivos e passava o fim de semana inteiro no quarto dormindo. Afastou-se pela segunda vez; o INSS queria um afastamento superior a trinta dias, mas ela temia o desemprego. Quando retornou ao trabalho, teve problemas com pressão alta e um problema no intestino, ocasionando um novo afastamento. Seu marido escondia os seis remédios que ela tomava porque o médico alertara que ela poderia sofrer uma overdose. Maria conta que sempre batia as metas e chegou a ganhar viagens por ficar entre as primeiras colocações nos rankings. Ela acha que adoeceu porque era honesta e não mentia aos clientes nem barganhava vendas. Desenvolveu depressão, só dormia meia hora por dia e pensou em se matar. Maria desenvolveu um câncer de mama que, segundo ela, só $2 \%$ das mulheres 
vivem mais de 10 anos. Maria atualmente está afastada pelo INSS e disse que esqueceu de vários detalhes porque faz tratamento psicológico para esquecer os fatos do trabalho. Ela tem uma ação para conversão de benefício em curso perante o sindicato.

O segundo entrevistado será denominado João. Após trabalhar por 35 anos em bancos, aposentou-se em um dos maiores bancos públicos do país depois de vinte anos de contrato de emprego. Também desempenhava a função de gerente. Compartilha com Maria a insatisfação com a incorporação de uma série de atividades que não eram de bancários à figura do gerente; afirmou que bancário deveria voltar a ser "apenas bancário". Por desempenhar a mesma função de Maria, relatou a pressão por metas semelhante. Disse que as metas acabam com a moral e abala o indivíduo. Havia um quadro na parede e ficava abalado quando via colegas que venderam mais do que ele nos rankings. Era cobrado duas vezes por dia. João fala que barganhava com os clientes trocar uma venda por um crédito ou pedia "por favor" para os clientes comprarem algo. Passava o tempo todo nervoso e não tinha horário, o que prejudicava sua relação com a família. Relutava em ser afastado, mas teve que sê-lo por estresse em 2010. Chorava muito no banco e passou a ter insônia, o que o levou a fazer tratamento psicológico. Disse que trabalhava com 16 colegas, dos quais nove também faziam tratamento. Há cerca de cinco anos, desenvolveu manchas escuras por toda a pele; os oito dermatologistas que o examinaram atribuíram as manchas à somatização do estresse. Relatou que os médicos lhe disseram que ele era muito forte, porque esteve à beira de um infarto ou um derrame. João conta que, antes das manchas surgirem, teve uma fissura no ânus e teve que operar; os médicos disseram que era fruto da tensão a que estava submetido. João conta que é outra pessoa depois da aposentadoria e não se lembra do banco no seu cotidiano. Tem uma filha que virou bancária, mas saiu porque a pressão estava prestes a acabar com o seu casamento. João procurou o sindicato para ingressar com uma reclamação por danos morais, mas achou melhor esquecer o passado.

O terceiro entrevistado será denominado José. Trabalhou dos 24 aos 29 anos como caixa de um dos maiores bancos privados do país. Relata que tinha metas de vendas de produtos (cartões, seguros, previdência etc.) além de atender a fila e dispensar tratamento de qualidade e rápido aos clientes. Acha que ter metas de vendas e lidar com vultosas quantias de dinheiro no caixa é um absurdo. Seu chefe lhe cobrava pelas vendas três vezes ao dia e José fala que o banco não se preocupava com a qualidade, só com as vendas. José relata ser impossível atender um cliente no caixa com qualidade e rapidez. Disse que ficava 
nervoso e mal humorado e começou a tratar mal os clientes por causa do tempo, somente respondendo sim ou não. Por ter que vender produtos e lidar com dinheiro, atrapalhava-se e sofreu muitos descontos por diferença de caixa. Após relutar, tomou remédios para ansiedade e depressão por 15 meses. José fala que passava o fim de semana trancado no quarto e só saía pra trabalhar. Afastou-se pela previdência por três meses por estresse; quando retornou ao trabalho, o banco esperou o fim do período de estabilidade e o dispensou. José fala que sua vida melhorou muito após a dispensa e que já rejeitou duas propostas para voltar a bancos. José tem uma ação por diferença de caixa no valor de $\mathrm{R} \$$ 8.000 e danos morais pelo sindicato.

3.3.4 Ações judiciais comuns à categoria bancária a comprovar o assédio moral organizacional nos bancos

Os bancos potencializam seus lucros através do aumento da produtividade de seus empregados, submetendo-os a um ambiente de trabalho de intensa pressão. O resultado são trabalhadores extenuados, fatigados, deprimidos, doentes, derrotados. Os vultosos lucros dos bancos são obtidos mediante a degradação física e mental de seus empregados, em clara afronta ao sistema jurídico do país.

As ações judiciais mais frequentes demandadas por bancários contra os bancos permitem supor que o Poder Judiciário tem plenas condições de compreender a ocorrência de uma situação de assédio moral organizacional nos bancos. Para isso, a Justiça deve encarar o seu acionamento geral não como a soma de problemas individuais e sim como a síntese de um setor econômico que utiliza o medo, o stress, a competição como instrumento de gestão de recursos humanos.

Quatro observações iniciais devem ser feitas. Primeiro, nem todos os trabalhadores bancários procuram o sindicato ou um advogado particular para acionar os bancos na justiça por vários motivos. Um bancário com contrato de emprego vigente raramente processa o banco porque sabe que será dispensado; muitos não conseguem testemunhas porque um empregado só se dispõe a depor em juízo após o encerramento do contrato e as reclamações só prosperam com provas testemunhais; muitos bancários intencionam permanecer trabalhando em bancos e temem ter seu nome em uma lista negra. 
A segunda observação é que cada agência representa um centro próprio de poder. É possível que o banco tenha uma política determinada na área de gestão de pessoas, mas um gerente geral não a aplique em sua agência visando aumentar a sua produtividade. A terceira é que a análise que segue foi feita baseada na experiência vivenciada pelo autor na assessoria jurídica do Sindicato dos Bancários do ABC.

Por fim, há que se ressaltar que milhares de trabalhadores bancários são terceirizados ilegalmente. Estes estão submetidos a uma situação de assédio mais greve porque a pressão é a mesma, mas os salários e demais direitos são muito inferiores aos da categoria. Estes trabalhadores são vinculados a outros sindicatos e suas reclamações dizem respeito a reconhecimento de vínculo e garantia dos direitos da categoria bancária.

Feitas essas ressalvas, analisa-se as ações mais frequentes demandadas por empregados bancários para que se perceba que o Poder Judiciário tem conhecimento do assédio moral organizacional nos bancos. As ações estão na seara trabalhista, previdenciária e danos morais.

Algumas reclamações trabalhistas envolvendo bancos são bastante comuns porque envolvem desrespeito a direitos em massa. Destacam-se as ações pedindo horas extras relativas à sétima e oitava, horas extras excedentes à oitava, intervalo intrajornada, equiparação salarial, quebra de caixa, salário de substituição e danos morais.

A CLT estabelece uma jornada especial para a categoria bancária nos termos abaixo.

\footnotetext{
Art. 224 - A duração normal do trabalho dos empregados em bancos, casas bancárias e Caixa Econômica Federal será de 6 (seis) horas continuas nos dias úteis, com exceção dos sábados, perfazendo um total de 30 (trinta) horas de trabalho por semana.

$\S 1^{\circ}$ - A duração normal do trabalho estabelecida neste artigo ficará compreendida entre 7 (sete) e 22 (vinte e duas) horas, assegurando-se ao empregado, no horário diário, um intervalo de 15 (quinze) minutos para alimentação.

$\S 2^{\circ}$ - As disposições deste artigo não se aplicam aos que exercem funções de direção, gerência, fiscalização, chefia e equivalentes, ou que desempenhem outros cargos de confiança, desde que o valor da gratificação não seja inferior a 1/3 (um terço) do salário do cargo efetivo.
}

Por questões de segurança, os bancos tem horário de funcionamento restrito entre as $10 \mathrm{~h}$ e as $16 \mathrm{~h}$. A categoria bancária logrou êxito em sua luta para reduzir a sua jornada também a seis horas diárias e trinta semanais, jornada essa absorvida pela CLT. 
A categoria bancária possui convenções coletivas nacionais instituindo comissões de conciliação prévia nos principais bancos do país, com a inglória exceção do Bradesco que se recusa a aderir. Além disso, os sindicatos de bancários dispõem de suporte jurídico de advogados que atendem os trabalhadores e patrocinam ações na justiça comum ou trabalhista.

É possível afirmar que horas extras que excedem a jornada especial de $6 \mathrm{~h}$ é o pedido mais frequente da categoria. Os bancos não se conformam com o contrato de emprego com jornada reduzida e desrespeitam a legislação todo o tempo, o que demanda reclamações trabalhistas com frequência elevada.

Os bancos só reconhecem o direito à jornada especial aos empregados de "menor patente" a exemplo de caixas e escriturários e mesmo aqui há problemas. Um caixa, por exemplo, pode permanecer de $10 \mathrm{~h}$ às $16 \mathrm{~h}$ em seu posto e permanecer trabalhando após esse horário. Primeiro porque, quando o banco fecha as portas, os clientes que já entraram continuam o atendimento independente de quantos estejam presentes. Nos chamados dias de pico, por exemplo, o volume de clientes eleva-se consideravelmente demandando mais tempo de trabalho. Segundo porque, ao finalizar os atendimentos, os caixas tem que conferir os valores, registrar as movimentações e realizar outras tarefas menores e que também absorvem tempo que excede o quanto estipulado pela legislação.

O problema maior diz respeito à exceção contida no parágrafo segundo do art. 224 . Ao retirar do âmbito de incidência da jornada especial os empregados que exercem função de direção, gerência, chefia, fiscalização ou outras funções de confiança, a CLT deu margem aos abusos do banco, que enquadram toda sorte de funcionários na exceção do parágrafo.

Se o empregado assume uma tarefa um pouco menos simples, o banco automaticamente retira-o da jornada especial e impõe-lhe as oito horas constitucionais. As inúmeras reclamações mostram uma gama de bancários de funções simples que não dispõem do direito às seis horas. Tesoureiros, supervisores, empregados da retaguarda, várias são as situações de abuso.

O caso mais frequente envolve os gerentes de vendas. Estes são os que mais procuram o sindicato em busca de suporte jurídico. Esses gerentes são meros vendedores dos produtos e serviços dos bancos ou captadores de clientela. O fato de ser-lhes exigido escolaridade elevada, vestes mais formais e tratamento de excelência ao público não lhes 
confere um caráter de confiança extraordinário. Uma vendedora da Daslu, por mais qualificada que seja, é tão vendedora quanto uma do Bom Retiro.

A jurisprudência não é conclusiva porque atem-se a cada caso como se fosse uma questão única. As dificuldades probatórias impõem-se porque um bancário só se dispõe a servir de testemunha - e não há outro tipo de prova adequada - se já estiver desligado do banco. E mesmo quando a prova é farta, os juízes não sentenciam uniformemente; há várias decisões favoráveis tanto ao banco quanto ao bancário envolvendo rigorosamente as mesmas situações.

A Justiça do Trabalho entende que a confiança bancária não é a mesma confiança preceituada pelo art. 62 da CLT. Embora todas as sentenças e acórdãos o declarem, isso não quer dizer rigorosamente nada porque as decisões dizem o que a confiança bancária não é, mas não dizem o que é. Tem-se um quadro onde os bancos interpretam a lei de uma forma, os trabalhadores interpretam de outro modo e o Poder Judiciário não resolve o impasse, limitando-se a agir caso a caso e em acordo à interpretação do respectivo juiz.

O caput de um artigo de lei é a regra; o parágrafo é a exceção. A situação atual dos bancos é tal que o número de casos que deveriam ser excepcionais é quase o mesmo número de casos da regra.

Além da sétima e oitava horas, a frequência da reivindicação do pagamento de horas extraordinárias dá a dimensão do que se passa no ambiente dos bancos. Muitas agências pagam normalmente pelas horas extras, evitando reclamações nesse sentido. Mas ainda é comum que empregados batam o ponto e permaneçam trabalhando ou comecem o trabalho antes do horário antes mesmo de registrar o ponto.

Esse pedido é mais frequente em relação aos gerentes de venda, que são os que mais sofrem com a cobrança das metas porque deles depende a captação e manutenção dos principais clientes. Esse segmento da categoria bancária é o mais mobilizável subjetivamente porque os bancos projetam neles a figura do bancário moderno e objetivamente porque recebem salário maior, tem perspectiva de crescimento na carreira e suas metas são as mais draconianas.

Completa a lista das reclamações trabalhistas mais comuns relacionadas ao tempo de trabalho os pedidos pelo intervalo intrajornada conforme previsto no art. 71 da CLT. A rotina frenética da categoria impede até mesmo a pausa para refeição ou descanso. Como pode parar por 15 minutos um caixa com a fila perante seu guichê? Como pode almoçar um gerente de vendas se seu colega ao lado trouxe um lanche para comer às pressas 
enquanto termina um relatório ou faz algumas ligações? Como pode repousar um funcionário da retaguarda se a vanguarda não para de enviar-lhe novas demandas que devem ser resolvidas de imediato para que se atenda ao público?

Esses três pedidos acima - horas extras referentes à sétima e oitava, excedentes à oitava e intervalo intrajornada - demonstram que a organização abusa em muito o poder diretivo do empregador. As metas de desempenho impostas aos trabalhadores bancários são excessivas, abusivas, impossíveis de serem cumpridas em um ambiente saudável e equilibrado.

Há a pressão vertical imposta pelo banco, horizontal pela competição com os demais colegas pelos postos mais altos nos rankings e transversal imposta pelos clientes. Para conseguir cumprir com as metas pré-estabelecidas, os bancários trabalham muito além do máximo de trabalho legalmente permitido. Extrapolam a jornada legal e não conseguem parar para descansar, o que os leva à exaustão física e psíquica com consequências aterradoras à sua saúde.

Outras ações deveras repetitivas devem ser lembradas. A primeira é a chamada quebra de caixa. Ao final do expediente, os caixas devem conferir os valores creditados e debitados no dia. Como são muitos clientes a serem atendidos, um único caixa responde pelas operações de centenas de clientes, sendo possível movimentar milhões de reais no mesmo dia.

Essas operações são realizadas no menor tempo possível, o que envolve o atendimento propriamente dito, conferência dos valores, digitação na calculadora e lançamento da operação. Ocorre que bancários não são máquinas e podem errar. Um único erro ao longo do dia significa desconto salarial, o que é um absurdo.

$\mathrm{O}$ art. $2^{\circ}$ da CLT atribui ao empregador os riscos da atividade econômica. A alteridade significa que, se o banco é quem assume os bônus da atividade, deve arcar também com os ônus. Uma instituição com agências espalhadas em todo o país atendendo freneticamente milhões de clientes diariamente sabe que, em algum momento, alguém cometerá algum erro porque ninguém consegue trabalhar com margem de erro igual a zero, somente computadores o fazem.

Lamentavelmente, os bancos mantem a prática ilegal de descontar dos salários dos seus empregados eventuais diferenças de caixa registradas ao fim do dia, ao arrepio da CLT que assim dispõe: 
Art. 462 - Ao empregador é vedado efetuar qualquer desconto nos salários do empregado, salvo quando este resultar de adiantamentos, de dispositivos de lei ou de contrato coletivo.

$\S 1^{\circ}$ - Em caso de dano causado pelo empregado, o desconto será lícito, desde de que esta possibilidade tenha sido acordada ou na ocorrência de dolo do empregado. (...)

Os bancos alegam que os descontos por quebra de caixa estariam previstos na convenção coletiva nacional ao instituir a gratificação de caixa. Esse argumento é um total absurdo porque não há nenhuma previsão de que a gratificação dos caixas prevista na CCT seja relacionada a quebras de caixa e porque há gratificações para diversos cargos, não só os caixas as percebem.

A proteção ao salário embasa ainda três reclamações também bastante comuns: a equiparação salarial, o acúmulo de funções e o salário de substituição.

A equiparação está prevista na CLT, que assim o prescreve: “Art. 461 - Sendo idêntica a função, a todo trabalho de igual valor, prestado ao mesmo empregador, na mesma localidade, corresponderá igual salário, sem distinção de sexo, nacionalidade ou idade".

É muito comum que um banco assedie um empregado de outro banco, mormente em se tratando de gerentes de venda pela possibilidade destes trazerem parte de sua carteira de clientes consigo. Para retirar o novo empregado da concorrência, os bancos oferecem vantagens e normalmente esse novo empregado já chega recebendo um salário maior do que o de seus novos colegas.

Os gerentes de venda sempre se queixam de que os profissionais "do mercado", aqueles que vêm de outro banco atraídos por salários maiores, recebem mais do que os profissionais "da casa", gerando desconforto e insatisfação. Disso resultam inúmeras reclamações de equiparação salarial.

Acúmulo de função e salário de substituição são dois institutos consolidados pela doutrina e jurisprudência a partir de uma interpretação sistemática do ordenamento jurídico vigente. O salário de substituição foi objeto do Enunciado 159, I do TST que dispõe que “enquanto perdurar a substituição que não tenha caráter meramente eventual, inclusive nas férias, o empregado substituto fará jus ao salário contratual do substituído".

Quando um funcionário de alguma hierarquia se afasta por qualquer motivo ou é transferido e gera uma vacância temporária, outro funcionário é convocado para substitui- 
lo temporariamente, normalmente um subordinado. Os bancos não pagam ao empregado substituto o salário do empregado substituído, alegando eventualidade independente do tempo que dure a substituição. A preocupação em manter o funcionamento da máquina é inversamente proporcional à preocupação em honrar os direitos de seus trabalhadores.

O acúmulo de função é comumente fundamentado no art. 468 da CLT, que veda a alteração contratual lesiva ao empregado, e no art. 884 do Código Civil, que veda o enriquecimento sem causa. Também aqui ocorre uma vacância, mas a ocupação da vaga é feita por um empregado a acumula com as suas tarefas anteriores; não há uma troca de função, há um acúmulo.

O acúmulo de função ocorre de todas as formas imagináveis em um banco. Um gerente assume a carteira de um colega que se afastou, um gerente geral acumula seu cargo com uma carteira de clientes, um tesoureiro que assume um guichê de caixa, um escriturário que assume dupla função.

Reclamações com esses pedidos são ajuizadas aos montes na Justiça do Trabalho. Esses fatos ocorrem com uma frequência tão alta que é lícito supor que a práxis dos bancos é desrespeitar os direitos de seus empregados e respeitar é a exceção.

As ações relativas ao tempo de trabalho (horas extras referentes à sétima e oitava, excedentes à oitava e intervalo intrajornada) são muito generalizadas e dimensionam como os bancários interiorizam a pressão e sentem-se obrigados a cumprir suas metas a qualquer preço. As demais ações citadas demonstram como os bancos não admitem falhas nem interrupções no trabalho, mantendo os empregados sobre permanente pressão.

No que diz respeito ao Direito Previdenciário, uma quantidade elevadíssima de trabalhadores bancários acessam o INSS diretamente ou ingressam com ações previdenciárias. Os pedidos mais frequentes referem-se à percepção do auxílio-doença previsto no art. 59 da Lei 8.213 e do auxílio-acidente previsto no art. 86 da mesma lei, embora hajam outros pedidos menos frequentes como aposentadoria por invalidez.

O auxílio-doença é um auxílio no valor de $91 \%$ do salário de benefício pago pela previdência ao segurado a partir do $16^{\circ}$ dia de afastamento. $\mathrm{O}$ auxílio-acidente é pago após o segurado retornar ao trabalho quando a lesão deixa sequelas e tem valor de $50 \%$ do salário de benefício.

O acidente de trabalho está elencado no art. 19 da Lei Previdenciária, cujo caput preceitua: 
Art. 19. Acidente do trabalho é o que ocorre pelo exercício do trabalho a serviço da empresa ou pelo exercício do trabalho dos segurados referidos no inciso VII do art. 11 desta Lei, provocando lesão corporal ou perturbação funcional que cause a morte ou a perda ou redução, permanente ou temporária, da capacidade para o trabalho.

Para efeitos desta lei, equiparam-se ao acidente de trabalho as doenças profissionais ou do trabalho (art. 20) e acidentes ligados ao trabalho ou sofridos no local ou horário de trabalho (art. 21).

Os empregados dos bancos são vítimas de doenças profissionais ou do trabalho bastante características já reconhecidas pelo NTEP, a exemplo de tendinite, tenossinovite ou depressão. Fatos equiparados a acidente também são comuns como sequestro ou assaltos, onde o empregado sofre forte abalo emocional que o impede de trabalhar.

Para fazer valer seus direitos, o trabalhador bancário atravessa longo e tortuoso percurso. Primeiro porque os bancos se recusam a emitir a Comunicação de Acidente de Trabalho (CAT) atestando que seu empregado sofreu acidente tipificado na Lei Previdenciária. Destaca-se negativamente aqui os casos que envolvem sequestro.

Há organizações criminosas especializadas em sequestro de bancários que tenham acesso ao cofre. Investigam o cotidiano da vítima, sequestram toda a família e os mantem em cativeiro até que o bancário dirija-se à agência e traga o dinheiro do cofre como resgate. Os bancários submetidos a sequestro vivenciam uma situação traumática onde o destino de seus familiares está em suas mãos e abalo emocional é fortíssimo. Os bancos recusam-se a emitir a CAT por não reconhecer o incidente como um acidente de trabalho e dispensa o empregado tão logo este retorne do afastamento e cesse sua estabilidade.

Muitos bancários que sofrem acidente de trabalho ou equiparações tem negado pelo INSS o benefício e ingressam com ação na justiça, assim como os que recebem o auxílioacidente na modalidade B 31. Esta distingue-se da modalidade B 91 por não reconhecer o nexo causal entre a moléstia e o trabalho, o que acarreta dois prejuízos principais. Com o auxílio na modalidade B 91, o segurado continua tendo seu FGTS recolhido pelo banco e o tempo de afastamento é computado para fins de aposentadoria, o que não ocorre quando o benefício é o B 31 .

Quando solicita o benefício administrativamente perante o INSS ou quando o faz através de ação judicial, o segurado depende do parecer do perito que o examinará e a suas condições de trabalho para aferir se há a moléstia alegada e se essa tem relação com o 
trabalho. Ocorre que os peritos são em número insuficiente e não recebem formação adequada. Agrava a situação o fato de muitas agências terem sido reformadas ao longo dos anos e ser impossível aos empregados mais antigos provar que laboravam em condições ergonômicas inadequadas.

O mais importante a observar do volume de afastamentos previdenciários da categoria é que ocorrem com tamanha frequência e acometem tantos bancários que tornamse prova cabal de que o Estado conhece os efeitos deletérios do trabalho em banco e nada faz preventivamente, atuando apenas quando o mal está feito e as doenças consolidadas no corpo e na mente do empregado.

A situação é tão grave que Maria Maeno (2011, p. 220) afirma, com base na Pesquisa Nacional de Amostra de Domicílios (PNAD) do IBGE de 2008, que cerca de 70 mil trabalhadores do sistema financeiro como um todo, o que inclui os bancários, foram diagnosticados com tendinite ou tenossinovite.

Muitas das ações trabalhistas e previdenciárias são acompanhadas de pedidos relativos a dano moral. Em sede previdenciária, o dano ao corpo ou à mente será comprovado ou não pela perícia judicial, o que facilita o deferimento do pedido porque a sua prova é a mesma do pedido principal. Se o empregado é afastado do trabalho por uma lesão no tendão ou por depressão, é notório que o dano moral configurou-se pois afetou a sua individualidade, a sua personalidade. É possível inclusive que haja sequela permanente, o que se reforçará a convicção do juiz.

Em sede trabalhista, as dificuldades são maiores. O dano moral é uma construção que encontra fundamento na constitucional dignidade da pessoa humana. Aplicar a Constituição a um caso concreto é algo que exige uma interpretação com alto grau de valoração e subjetividade que contrasta com a organização do Poder Judiciário brasileiro, baseado em leis positivas e aplicação silogística.

Fora isso, há uma departamentalização excessiva nas faculdades de direito que praticamente isolam as disciplinas como se houvesse um direito do trabalho, um direito civil, um direito constitucional autônomos, quando na verdade há um sistema jurídico único. E somente a partir de 1988 floresceu uma consciência constitucional de fato entre os juristas, algo que ainda está em processo de amadurecimento.

Se um empregado trabalha dez horas por dia com frequência, é obvio que há um dano moral aqui porque o empregador desrespeitou a legislação para aumentar a lucratividade em cima do empregado e isso atenta contra a dignidade da pessoa humana. 
Também o fato de o trabalhador estender sua jornada agride sua saúde e sua personalidade. Logo, todas as decisões que defiram o pagamento das horas extras deveria deferir o ressarcimento moral, mas isso não ocorre.

Não é fácil obter decisões favoráveis relativas a direitos da personalidade do trabalhador. Há uma campanha difamatória contra o instituto que alega haver uma "indústria do dano moral" e muitos juízes são convencidos disso. Criou-se inclusive a figura do "mero aborrecimento" que serve de panaceia para o indeferimento do dano; quando o juiz não o defere, fundamenta que houve apenas um "mero aborrecimento" e não uma agressão moral.

O Poder Judiciário em geral e a Justiça do Trabalho em particular ainda tem muito a avançar nessa questão. Há uma resistência forte em deferir pedidos relativos a danos e, quando são deferidos, os valores são baixos, risíveis para um dos setores que mais acumula riqueza no Brasil e no mundo. A lógica dos bancos é a de que o crime compensa e desrespeitam os direitos dos trabalhadores em massa. Para um banco, vale a pena ser processado porque aí demora-se mais tempo com o dinheiro entesourado e valorizando-se a juros. Ao final da execução, o banco já lucrou muito com o dinheiro pago pela condenação.

Conclui-se desse quadro que o Judiciário deveria ter uma postura mais pró-ativa para acabar com o ambiente geral de assédio moral organizacional nos bancos. Nesse aspecto, a Justiça do Trabalho demonstra-se sempre reativa, atuando nos casos isolados quando acionada, e de forma insuficiente para dar o exemplo e fazer os bancos temerem por uma condenação.

O trabalho em banco significa pressão intensa, adoecimento, afastamento e longa espera por uma decisão judicial que amenizará a situação danosa, mas não a cessará nem impedirá que os demais trabalhadores percorram o mesmo ciclo. Ao invés de proferir um milhão de sentenças condenatórias, o Judiciário deveria proferir umas poucas que intimidassem os bancos a não agredir a saúde de seus empregados novamente. 


\section{A LUTA SINDICAL É O MEIO ADEQUAdo A RESOLVER O PROBLEMA DO ASSÉDIO MORAL ORGANIZACIONAL}

As dificuldades encontradas pelo Poder Judiciário em resolver o problema do assédio organizacional sugerem que a solução do problema passa pelo conflito coletivo e direto entre os sindicatos de bancários e os bancos. Além dos problemas apontados no capítulo anterior, deve-se levar em consideração que a Justiça do Trabalho recebe mais de dois milhões de novas reclamações anualmente, congestionando o seu funcionamento.

O Brasil tem um histórico problemático no que diz respeito ao conflito coletivo de trabalho. Os diversos períodos autoritários vividos pelo país ao longo do século XX se ocuparam de barrar os conflitos coletivos com proibição da organização sindical, intervenção nas diretorias dos sindicatos, prisão e assassinatos de lideranças proletárias, proibição do direito de greve etc.

A legislação trabalhista brasileira foi engendrada visando a absorção dos conflitos coletivos pelo Estado. Capital e trabalho deveriam compor seus interesses com vistas ao desenvolvimento geral da nação. A CLT é o símbolo maior disso. Preceitua uma série de direitos individuais aos trabalhadores e institui uma justiça especializada em resolver os conflitos, ao passo que nega a liberdade sindical. Nem mesmo a Constituição Federal de 1988 resolveu o problema.

A categoria bancária é forte em comparação às demais categorias e se organiza em um movimento sindical representativo com alto grau de filiação, convenções coletivas nacionais, comissões de conciliação dentre outros mecanismos. Suas lutas por melhores condições de trabalho gerais e contra o assédio organizacional em particular sugerem que os bancários tem condições de protagonizar a resolução deste mal que lhes assola, servindo de exemplo para outras categorias ao solucionar um grave problema que lhe é peculiar mas não lhe é exclusivo. 
O conflito é um elemento característico das relações entre capital e trabalho. O trabalho assalariado pressupõe a apropriação privada dos frutos de um trabalho social e é inevitável que haja desavenças. Em um exemplo deveras simplório, o aumento salarial dos empregados implica em redução dos lucros do empregador. Como o objetivo da empresa é ter lucros e o objetivo do empregado é ter salário, a conta não fecha nunca e a definição de quem leva quanto mantem as partes em permanente tensão.

Para manter esse conflito em um nível que permita a mantença da produção e reprodução do capital, o Estado intervém absorvendo uma parte das reivindicações dos empregados e outra parte das reivindicações dos empregadores, estabelecendo um pseudo equilíbrio que encontra respaldo na violência estatal.

A história do Direito do Trabalho é a representação jurídica dos embates travados entre empregados e empregadores, aqueles lutando por melhores condições de trabalho e estes lutando pela maior apropriação possível do trabalho dos seus empregados. É possível (e desejável) que a solução deste embate seja a síntese da medição de forças entre as partes. Do contrário, haverá a intervenção (indesejável) do Estado para garantir o regular funcionamento econômico ao impedir que os conflitos degringolem e desestabilizem a economia.

Costuma-se classificar as formas de composição destes conflitos em três frentes: a autocomposição, a heterocomposição e a autodefesa.

$\mathrm{Na}$ autocomposição, as próprias partes conflitantes solucionam a querela mediante ajustes de vontades. Não há participação de terceiros na solução da lide. Uma das partes pode sacrificar seus interesses para o fim do litígio (renúncia) ou ambas as partes podem abrir mão de seus interesses (transação). O que importa é que o conflito é resolvido entre o capital e o trabalho sem sujeitos estranhos à querela.

Para a solução dos conflitos coletivos de trabalho mediante autocomposição, o Direito brasileiro reconhece a negociação coletiva ou a mediação.

As negociações coletivas podem originar uma convenção coletiva ou um acordo coletivo de trabalho. A convenção é um ajuste de vontades entre um sindicato de empregados e um sindicato de empregadores e o acordo coletivo é o ajuste entre um sindicato de empregados e uma empresa específica. A convenção ou o acordo são instrumentos normativos que regulamentam as relações de trabalho em seu âmbito de incidência. 
A mediação, conforme o Decreto $1.572 / 95$, poderá ser feita por mediador particular, caso em que as partes arcarão com os seus honorários, ou pelo Ministério do Trabalho e Emprego. O Brasil não tem tradição de resolução de conflitos coletivos via mediação particular, sendo que as mediações ocorridas perante o MTE são mais comuns. De qualquer forma, o mediador não é mais do que um facilitador que ajudará as partes a chegar a um acordo, pois são os representantes dos trabalhadores e das empresas que decidirão o conflito.

$\mathrm{Na}$ heterocomposição, há um terceiro envolvido que decide o conflito, impondo às partes a solução. A heterocomposição pode se dar por arbitragem ou jurisdição.

Assim como não há a tradição da mediação, também não há tradição de arbitragem no Brasil. O árbitro será escolhido de comum acordo pelas partes, que firmarão o compromisso arbitral estabelecendo as competências do árbitro limitando o seu decidir. A arbitragem está prevista no art. $114, \S 1^{\circ}$ da Constituição.

A jurisdição ocorre quanto o Poder Judiciário, literalmente, diz o Direito. O Poder Judiciário, com pretensões imparciais, analisa as reivindicações de lado a lado e decide imperativamente o conflito, exercendo a coerção estatal. Aqui, há a possibilidade de ajuizamento de dissídio coletivo ou de ações coletivas envolvendo direitos difusos, coletivos ou individuais homogêneos.

O dissídio coletivo ajuizado pode ser de natureza jurídica ou econômica. No primeiro caso, o Poder Judiciário será chamado a interpretar uma norma convencional já existente relativa à categoria envolvida. Já no dissídio de natureza econômica o Judiciário exerce de fato o Poder Normativo ao estabelecer as condições de trabalho em substituição à negociação das partes. A Emenda Constitucional 45 estabeleceu o mútuo consentimento como condição do dissídio, forçando empregados e empregadores esgotarem todas as possibilidades antes de ingressar em juízo.

O Poder Normativo da Justiça do Trabalho sempre foi alvo de contestação por parte do movimento sindical por representar uma interferência indevida do Estado nas relações de trabalho. A sentença normativa, na prática, substitui a convenção coletiva, retirando dos sindicatos o direito de negociar as condições de trabalho, configurando-se em um instituto paternalista e autoritário forjado por experiências fascistas.

Pode também o sindicato de trabalhadores ajuizar ações coletivas envolvendo direitos difusos, coletivos ou individuais homogêneos. Difusos são direitos transindividuais e indivisíveis relativos a uma coletividade indeterminada e ligada por uma circunstância de 
fato. Coletivos são direitos transindividuais e indivisíveis relativos a uma coletividade identificada por uma relação jurídica base consigo ou com a parte contrária. Individuais homogêneos são direitos individuais e divisíveis relativos a uma coletividade identificada por um evento de origem comum.

A Constituição Federal de 1988 legou aos sindicatos a ampla possibilidade de ajuizar ações coletivas ou individuais em defesa de seus associados em seu art. $8^{\circ}$, III. A Justiça do Trabalho refutou essa possibilidade durante anos após a promulgação da Constituição e foi necessário o STF manifestar-se sobre a ampliação da competência dos sindicatos em ajuizar tais ações de forma irrestrita, o que comprova que o Brasil ainda carece de uma revisão constitucional de seu Direito do Trabalho.

Por fim, a resolução do conflito por autodefesa ocorre quando há medição de força direta, com uma parte impondo a sua vontade à outra, como uma metafórica queda de braço. A autodefesa significa a greve pelo lado dos trabalhadores e o lockout pelo lado das empresas, ambas paralisações das atividades na(s) empresa(s) com o objetivo de forçar o lado contrário a aceitar uma imposição unilateral de vontades. A Constituição assegura o direito de greve no art. $9^{\circ}$, legando aos trabalhadores a decisão sobre a oportunidade e conveniência de instaurar o movimento paredista. O lockout empresarial é expressamente vedado pelo art. 17 da Lei 7.783/89. Há juristas que entendem não ser a greve uma técnica de solução do conflito coletivo, sendo apenas uma expressão desse conflito.

Apesar da previsão legal, o Brasil não tem tradição de mediação e arbitragem para solução de conflitos coletivos. Ou os sindicatos e as empresas resolvem por conta própria suas diferenças ou acionam o Poder Judiciário através do dissídio coletivo ou ações coletivas, sendo essa a tradição pátria. Frise-se que a Emenda 45 dificultou o ajuizamento de dissídios coletivos e só recentemente firmou-se o entendimento da ampla possibilidade dos sindicatos ajuizarem ações coletivas, reduzindo atualmente o número de dissídios e aumentando o número de ações coletivas.

A história do Direito do Trabalho demonstra os caminhos tortuosos pelos quais correm a regulamentação das condições de trabalho dos assalariados. Em alguns momentos há mais intervenção do Estado para impedir a superexploração da mão-de-obra por parte das empresas. Em outros, essa intervenção dá-se no sentido de impedir a luta sindical dos trabalhadores em benefício dos empresários. Em alguns países, há mais liberdade para os sindicatos e as empresas negociarem livremente as condições do labor ao passo que, em 
outros, há menos liberdade para negociações e o Estado intervém pesadamente nas regulações.

A doutrina trabalhista majoritária crê que os sindicatos devem dispor do máximo de liberdade para se organizar e negociar as condições de trabalho com as empresas, participando das decisões que afetam diariamente a vida dos empregados. O Direito deveria limitar-se a garantir a liberdade sindical e negocial e intervir em caráter suplementar.

Os trabalhadores conhecem plenamente a realidade que vivenciam no cotidiano laboral e tem o direito de participar das deliberações acerca da regulação das condições objetivas e subjetivas dessa realidade. A democratização das relações de trabalho é um direito fundamental de todo trabalhador, considerado individual e coletivamente. Tal democratização contrasta com o poder diretivo do empregador, caracterizado pela hierarquia e verticalidade.

As negociações coletivas protagonizadas pelos sindicatos de um lado e das empresas de outro visam estabelecer contratos coletivos de trabalho, que são normas jurídicas e se impõem na âmbito da empresa. A convenção coletiva e o acordo coletivo são a síntese das disputas entre os empregados e os empregadores, que lutam pelos seus interesses.

Por serem naturalmente conflituosas, as negociações coletivas foram duramente tolhidas no Brasil em dois períodos autoritários do século XX. O governo Vargas preocupou-se em canalizar parte da força dos empregados para a disputa individual com os empregadores a partir da outorga de uma gama de direitos individuais minuciosamente detalhados pela legislação e garantidos pela Justiça do Trabalho. Por que lutar com seu sindicato se já lhe são garantidos pelo Estado seus direitos?

Além de drenar a energia laboral predominantemente para a disputa individual, a CLT estatizou os sindicatos, esvaziou-lhes as funções e definiu seu funcionamento e financiamento, ferindo de morte e liberdade sindical e a força coletiva dos trabalhadores.

A ditadura instaurada a partir de 1964 de militar só tinha a forma porque o conteúdo era claramente definido em benefício do grande capital e dos interesses do empresariado. Os militares derrubaram um governo progressista que propunha-se a fazer populares reformas de base, proibiram o direito de greve, prenderam lideranças sindicais, nomearam interventores nos sindicatos e estabeleceram a fórmula de reajustes salariais por lei. Se um sindicato não pode sequer lutar pelo aumento dos salários dos seus associados 
nem fazer greve é porque novamente suas funções foram esvaziadas, sua utilidade reduzida e sua força tolhida.

Não coincidentemente a força coletiva dos trabalhadores foi um fator decisivo na derrubada dos militares. As greves do ABC em fins dos anos 1970 pararam o coração industrial do país, desafiando o governo tirânico e seu milagre econômico voltado para a concentração de renda e os interesses patronais. Infelizmente, a correlação de forças na Assembleia Constituinte impediu que a Constituição que assegurasse a liberdade sindical plena, embora trouxesse alguns tímidos avanços.

Paulo Eduardo Vieira de Oliveira (2008, p. 109) sugere que as negociações coletivas são melhores do que conflitos judiciais por serem as partes envolvidas as que melhor conhecem as causas do conflito e as possíveis soluções e porque "a negociação coletiva é a fórmula jurídica natural de solução de um conflito coletivo de regulamentação".

A negociação coletiva é a série de sucessivos atos que visam alcançar o entendimento entre as partes. Pode ocorrer para solucionar qualquer problema que eventualmente surja; mas, prioritariamente, tem como escopo o estabelecimento de uma convenção ou um acordo coletivo que tenha efeito de norma jurídica às partes negociantes.

Assim, as negociações coletivas são um procedimento, um instrumento, um meio para se solucionar conflitos de interesse entre o sindicato e as empresas sem que seja necessário recorrer a um terceiro ator estranho à lide. Seu resultado é a fixação das condições de trabalho e a regulação da relação mútua.

No Brasil, há a figura da data-base que marca anualmente o início das negociações. As tratativas preliminares envolvem a proposta de entendimento com a pauta prévia de reivindicações e o agendamento das reuniões. Normalmente os sindicatos apresentam uma minuta do contrato e todos os passos obtidos na mesa de reunião são levados pelos sindicatos à assembleia da categoria e pelos representantes patronais às suas instâncias decisórias.

O conflito é a regra nas relações envolvendo capital e trabalho. As negociações coletivas representam a explanação dos conflitos envolvendo diversos aspectos do trabalho como duração, remuneração e toda sorte de direitos. A assinatura de um acordo ou uma convenção coletiva representa a solução dada ao conflito, mesmo sabendo que uma das partes pode fazer uma concessão pontual e voltar à carga no ano seguinte. Se não houver 
acordo, o sindicato pode organizar uma greve, as partes podem buscar a mediação do Ministério do Trabalho e Emprego ou requisitar o Poder Normativo da Justiça do Trabalho.

Oliveira (2008, p. 112) sugere quatro tipos de negociações coletivas. A negociação coletiva de criação ocorre quando não há uma convenção ou acordo prévio e se estabelece um. De modificação ocorre quando se pretende alterar uma cláusula, condição ou princípio de uma convenção já existente. De substituição ocorre quando uma nova convenção supera a anterior. E de esclarecimento ocorre quando há confusão ou dubiedade sobre uma das cláusulas existentes e uma nova convenção surge para dirimir a dúvida.

As negociações coletivas diferem-se dos institutos jurídicos da conciliação, mediação e arbitragem porque estes ocorrem perante a presença de um órgão oficial ou um terceiro particular enquanto que aquelas envolvem exclusivamente a representação dos empregados e dos empregadores. Além disso, o laudo arbitral se impõe às partes ao passo que o acordo ou convenção coletiva depende da concordância de ambos.

As partes envolvidas nas negociações são as mesmas que podem celebrar contratos coletivos de trabalho: para uma convenção coletiva, as partes são os sindicatos de empregados e de empregadores; para um acordo coletivo, as partes são o sindicato de empregados e uma empresa.

Oliveira (2008, p. 114) afirma que há três obstáculos centrais ao sistema autocompositivo das negociações coletivas: a oposição patronal, a debilidade sindical e a intervenção estatal. Os três obstáculos apresentados encontram-se no Brasil.

A oposição patronal dá-se porque a classe dominante não aceita a participação dos sindicatos no que tange à gestão das empresas. Um contrato coletivo é, na prática, uma mitigação, um enfraquecimento do poder diretivo do empregador. Se este poder diretivo afirma que o empregador pode dirigir os empregadores, organizando e fiscalizando o trabalho e punindo os desvios, a contratação coletiva afirma que os empregados podem organizar-se coletivamente para estabelecer condições de trabalho não só visando os interesses das empresas, mas também dos trabalhadores.

Essa oposição é facilmente visível no país. Durante quase quatrocentos anos, o Brasil teve no escravismo a sua forma preferencial de trabalho e foi o último país do mundo a abolir a escravidão. Essa cultura de subordinação absoluta da força de trabalho, onde o próprio trabalhador era uma propriedade, não se desfez totalmente com o advento do capitalismo. Ainda hoje é frequente ver notícias de trabalhadores escravizados sendo resgatados, mormente em trabalho agrícola e no ramo da indústria têxtil. A PEC 438, que 
determina a expropriação das fazendas onde sejam encontrados trabalhadores escravizados, tramita há mais de uma década no Congresso Nacional e nunca foi votada por oposição da bancada ruralista.

A média salarial do Brasil está abaixo da média salarial mundial, mas o empresariado não perde uma oportunidade de reclamar dos custos da mão-de-obra e defender redução de direitos trabalhistas. A Convenção 158 da OIT não é ratificada pelo Congresso por oposição dos empresários que se arvoram o direito de dispensar os empregados ao seu bel prazer. Todos os períodos autoritários foram oportunizados pelas classes dominantes para impedir a livre organização sindical.

Os serviços públicos são conquistas históricas dos trabalhadores, mas as elites brasileiras fazem questão de negar qualidade à educação publica, saúde pública, segurança pública, transporte público e outros direitos sociais previstos inclusive pela Constituição.

Nessa conjuntura, é fácil perceber porque o empresariado se opõe às livres negociações coletivas. Opõem-se porque não aceitam a participação dos empregados organizados nas deliberações acerca das condições de trabalho nas empresas. Pensam estas como sua propriedade absoluta, como se a Constituição não preceituasse o valor social da propriedade e do trabalho. Sonegam aos trabalhadores o elementar direito de lutar por melhores condições de vida e trabalho.

A debilidade sindical apontada por Oliveira tem várias causas, sendo uma delas a oposição patronal vista acima. Na primeira década do século XXI houve significativa redução do trabalho informal no país; porém, mais de 1/3 dos trabalhadores continuam mantidos na informalidade, um número deveras elevado. Mantidos na informalidade, essa parcela considerável do trabalho fica desprotegida do arcabouço legal garantidor de direitos trabalhistas e previdenciários e fica impossibilitada de sindicalizar-se.

Os baixos salários e os péssimos serviços públicos sociais também contribuem para a debilidade sindical. Não é coincidência que as categorias dos sindicatos mais fortes tenham remuneração e qualidade de vida maior. Um salário baixo e condições de vida desfavoráveis aguçam o instinto de sobrevivência e a individualidade, o que é incompatível com a solidariedade que marca o sindicalismo.

Mas os principais fatores responsáveis pela debilidade sindical no Brasil, sem sombra de dúvida, são, em nível conjuntural, a situação econômica e, em nível estrutural, a intervenção estatal nas relações de trabalho. 
Observando a conjuntura econômica desde o advento do Plano Real, por exemplo, tem-se dois períodos nitidamente distintos. A década de 1990 representou o auge da hegemonia neoliberal no Brasil e no mundo e foram tempos difíceis ao movimento sindical. Desemprego em massa, terceirização abrupta da economia, informalidade crescente, salários achatados, crescimento econômico irrisório, aperto fiscal, dependência econômica, suspensão dos investimentos públicos e sucateamento dos serviços enfraqueceram os sindicatos que passaram todo o período se defendendo dos ataques contra os seus direitos.

A superação dessas mazelas iniciou-se em 2003 e acentuou-se a partir de 2005. Geração de milhões de empregos, aumento salarial acima da inflação constante, aquecimento econômico, redução da pobreza, investimentos públicos, fortalecimento dos serviços e contratação de servidores, pleno emprego ou quase isso reanimaram e fortaleceram o movimento sindical.

A título de comparação, a pauta da reforma trabalhista era totalmente vinculada à ideia de flexibilização nos anos 90: a denunciação da Convenção 158 da OIT em 1997, o contrato a prazo e o banco de horas da Lei 9.601/98, e o não aprovado Projeto de Lei 5.483/2001 que preconizava a predominância do negociado sobre o legislado, pauta principal do empresariado que, à época, estava em condições de chantagear os sindicatos a flexibilizarem toda e qualquer direito em troca do emprego.

Já no período atual, a flexibilização trabalhista saiu da pauta tanto da política nacional quanto da academia. Em um período que beira o pleno emprego, o jogo vira e os trabalhadores adquirem força para avançar em sua pauta, como foi o reconhecimento das centrais sindicais pela Lei 11.648/08, o acordo destas com o governo estabelecendo o reajuste do salário mínimo pelo crescimento econômico mais a inflação até 2015, e a luta sindical perante o Congresso para ratificar a Convenção 158 da OIT e aprovar a PEC 231, reduzindo a jornada semanal de $44 \mathrm{~h}$ para $40 \mathrm{~h}$.

O contraste entre os dois períodos expressa-se na análise dos reajustes salariais oriundos das negociações coletivas. Observa-se os percentuais de negociações que trouxeram reajustes acima da inflação, os chamados aumentos reais. Os dados são do DIEESE (2012). 51,9\% das negociações coletivas realizadas em 1996 tiveram reajustes acima da inflação. Esse percentual foi de 39,1\% em 1997, 43,5\% em 1998, 35,1\% em 1999, 51,5\% em 2000, de 43,2\% em 2001 e 25,8\% em 2002. Percebe-se que, no máximo, metade das categorias analisadas tinha aumento real nesta quadratura histórica. 
O governo mudou em 2003, ano que apenas 18,8\% das negociações coletivas resultaram em aumento real. Esse percentual começou a recuperar-se em 2004 com 54,9\% e, a partir de então, tem-se um quadro onde a imensa maioria das negociações aumentarou o ganho da massa salarial. Em 2005, 71,7\% das negociações tiveram reajuste acima da inflação; 86,3\% em 2006, 87,7\% em 2007, 77,6\% em 2008, 79,9\% em 2009, 88,7\% em 2010 e $86,8 \%$ em 2011. Considerando as categorias que obtiveram aumentos reais somadas às que apenas repuseram a inflação, tem-se que esses índices mantem-se consistentemente acima dos $90 \%$ nos últimos anos.

Outro indicador trazido pelo DIEESE (2012a) que indica o bom momento para os sindicatos é o referente às greves. Em 2008, verifica-se um aumento do número de movimentos paredistas revertendo uma tendência que vem desde o início da década de 1990. Em 2008, ocorreram 411 greves, número muito superior às 316 do ano anterior. Em 2009, foram 518 greves e 446 em 2010. Além do aumento quantitativo, verifica-se uma importante mudança qualitativa se comparados os anos de 2009 e 2010. Nota-se que aumentou, proporcionalmente, a quantidade de greves propositivas, que reivindicam novos direitos ou ampliação dos existentes, e que diminuíram as greves defensivas, que reivindicam apenas a manutenção dos direitos. Entre 2009 e 2010, as greves propositivas variaram de $67,4 \%$ para $79,1 \%$ e as defensivas variaram de $48,8 \%$ para $45,5 \%$.

Estruturalmente, tem-se que a intervenção do Estado nos sindicatos também enfraquecem estes e as negociações coletivas. Em boa parte da história brasileira, houve regimes de exceção, ditatoriais, que destituíram e prenderam lideranças sindicais, nomearam interventores pelegos nos sindicatos, proibiram o direito de greve. É preciso lembrar que somente a partir de 1995, os sindicatos puderam negociar livremente os reajustes salariais porque os militares esvaziaram os sindicatos ao fixar os índices de reajustes.

O chamado sindicalismo autêntico sempre lutou contra o que chama de tripé autoritário: o imposto sindical, a unicidade imposta por lei e o Poder Normativo da Justiça do Trabalho. Esses três elementos ainda persistem no Brasil, impossibilitando a liberdade sindical plena e contribuindo para a existência dos atuais 10 mil sindicatos, a maioria esmagadora sem nenhuma representatividade, que só existem para fragmentar os sindicatos mais fortes e recolher o imposto sindical respectivo.

A despeito dos obstáculos, as negociações coletivas têm crescido em importância no país nos últimos anos e se destacado enquanto fonte do Direito do Trabalho. Embora 
não seja o único, o objetivo central das negociações é o estabelecimento de acordos ou convenções coletivas de trabalho.

Preceitua o art. 611 da CLT:

\begin{abstract}
Art. 611 - Convenção Coletiva de Trabalho é o acordo de caráter normativo, pelo qual dois ou mais Sindicatos representativos de categorias econômicas e profissionais estipulam condições de trabalho aplicáveis, no âmbito das respectivas representações, às relações individuais de trabalho.

$\S 1^{\circ}$ É facultado aos Sindicatos representativos de categorias profissionais celebrar Acordos Coletivos com uma ou mais empresas da correspondente categoria econômica, que estipulem condições de trabalho, aplicáveis no âmbito da empresa ou das acordantes respectivas relações de trabalho.

$\S 2^{\circ}$ As Federações e, na falta desta, as Confederações representativas de categorias econômicas ou profissionais poderão celebrar convenções coletivas de trabalho para reger as relações das categorias a elas vinculadas, inorganizadas em Sindicatos, no âmbito de suas representações.
\end{abstract}

Esse artigo define à inteireza convenção e acordo coletivo de trabalho. Inicialmente, frise-se que ambos os institutos configuram-se como contratos coletivos de trabalho, mas a legislação pátria optou pela denominação de convenção e acordo. Este trabalho poderá se valer da denominação contrato coletivo para referir-se à convenção e ao acordo coletivo.

Convenção e acordo coletivos são estipulações travadas entre a representação sindical de trabalhadores e a representação sindical de empresas ou empresas individualmente a regulamentar as condições de trabalho comuns à categoria. Trata-se de um acordo escrito que tem efeito de norma jurídica entre as partes e versa sobre os mais diversos temas como jornada, remuneração, gratificações, auxílios, PLR etc.

Amauri Mascaro Nascimento (2009, p. 1334/1335) destaca alguns elementos importantes da definição legal brasileira. Convenções e acordos coletivos possuem natureza autocompositiva e consensual, verdadeiro ajuste de vontades entre as partes, empregados e empregadores. Possui natureza jurídica a despeito de não emanar do Estado, mas este reconhece os efeitos dos acordos e convenções e lhes garante vigência se demandado pelas partes. Pode ser celebrado pelo sindicato de empregados com a empresa diretamente (acordo coletivo) ou com o respectivo sindicato patronal (convenção coletiva), produzindo efeitos apenas para os representados pelas entidades contratantes; na ausência de sindicato organizado da categoria, poderá ser celebrado por federação ou confederação. Terão conteúdo obrigacional as cláusulas que estipularem direitos e deveres entre as partes 
vinculados às obrigações contratadas e conteúdo normativo as cláusulas que fixarem normas aos contratos individuais de emprego.

A célebre metáfora que afirma ter a convenção e o acordo coletivo "corpo de contrato e alma de lei" indica as discussões doutrinárias acerca de seu caráter: seriam os institutos uma lei ou um contrato?

A despeito de ser, de fato, um contrato estabelecido entre as partes, os contratos coletivos de trabalho aplicam-se à toda a categoria cuja base pertença ao sindicato convenente. Significa dizer que tais contratos aplicam-se aos associados e aos não associados ao sindicato, dificultando a interpretação de que seriam contratos stricto sensu, de origem civilista. Por isso, a compreensão geral do Direito do Trabalho brasileiro é pelo caráter normativo dos contratos coletivos; estes estariam mais próximos de uma lei por seus efeitos ultracontraentes do que de um contrato de direito privado clássico, que necessita da concordância da parte para surtir efeito. Sugere Nascimento (2009, p. 1337) que "não há argumentos maiores que possam refutar o caráter normativo das convenções e a sua inclusão ao lado das demais normas do direito positivo”.

Tal compreensão das convenções e acordos coletivos enquanto norma jurídica só será possível mediante a aceitação das teses defensoras do pluralismo jurídico, oposto ao monismo jurídico. Enquanto o monismo reconhece tão somente o Estado enquanto fonte de direito, o pluralismo nega esse monopólio estatal da criação jurídica e afirma haver diversos centros de produção de direito na sociedade civil.

Ronaldo Lima dos Santos afirma que já podia ser observado um certo pluralismo jurídico em Roma Antiga quando o Império Romano reconhecia a validade do direito dos povos conquistados. Da mesma forma, na Idade Média europeia havia uma pluralidade de esferas normativas representados pela Igreja, reinos, feudos, corporações de ofício etc. Mas o pluralismo moderno surge em confrontação com o monismo resgatado pelo Estado Absolutista que centralizou a produção de leis e do direito. Nas palavras de Santos (2009, p. 38), "uma doutrina pluralista afirma a existência de outros centros de produção jurídica além do Estado, cujas normas estão num mesmo plano de igualdade, admitindo-se, apenas, diferenças quanto à extensão da validade dos preceitos”.

Como fatores que favoreceram as concepções pluralistas no direito, são apontados o envelhecimento das codificações estáticas e insuficientes; a industrialização, urbanização, complexidade e diversidade crescentes da sociedade; e o desenvolvimento das ciências 
sociais, inclusive as jurídicas, que observavam uma sociedade pujante pra fora do Estado e alimentaram criticamente o estudo do Direito.

As concepções pluralistas estão alinhadas a uma concepção de sociedade democrática e o monismo, a uma sociedade autoritária. A Constituição Federal de 1988, encerrando um tenebroso período tirânico, notadamente tendeu para o pluralismo em diversas frentes. Já em seu preâmbulo, os constituintes comprometeram a Constituição com o desenvolvimento de uma sociedade pluralista, indicando os caminhos para a concretização da justiça e da democracia apregoados.

Diversos dispositivos constitucionais asseguram o pluralismo em diversas situações de forma expressa ou implícita. Logo no art. $1^{\circ}, \mathrm{V}$, afirma-se o pluralismo político enquanto fundamento do Estado Democrático de Direito. É notória a associação às concepções do pluralismo jurídico o reconhecimento da autonomia privada coletiva pelo art. $7^{\circ}$, VI, XIII, XXVI e da negociação coletiva de trabalho pelo art. $8^{\circ}$, VI. O art. 17, caput, atrela a soberania, a democracia e os direitos fundamentais à liberdade e ao pluralismo partidário. O art. 170 não utiliza a expressão "pluralismo", mas assegura o pluralismo econômico. O art. 206, III, assegura o pluralismo de ideias e de pedagogias enquanto base do ensino e da educação. Também afirmam implicitamente o pluralismo os arts. 215 a 217 (pluralismo cultural) e o art. 220, $\S 5^{\circ}$ (pluralismo dos meios de informação através da vedação de monopólio ou oligopólio, direta ou indiretamente).

A filosofia política e jurídica adotada pela constituição brasileira é claramente voltada às noções de diversidade, pluralidade, heterogeneidade, liberdade e conflituosidade. Não há espaços para poderes concentrados, homogêneos e autoritariamente impostos. A concretização dos objetivos e princípios constitucionais depende de todo o povo e suas organizações e a este povo foi legada a liberdade e a participação social em várias frentes. A dignidade e o pluralismo caminham lado a lado e é possível comprovar tal assertiva pela análise dos dispositivos constitucionais acima explicitados.

A sociedade de classes brasileira e suas diversas clivagens socioeconômicas demandam a pluralidade político-partidária para que os diversos interesses conflitantes possam ser representados no jogo político-institucional e os destinos da nação sejam a síntese desses conflitos. A contradição entre a propriedade privada e o trabalho social será melhor equilibrada (mas não resolvida) pela contratação coletiva das condições de trabalho entre os sindicatos de trabalhadores e as empresas ou seus sindicatos do que pela 
intervenção estatal. A economia capitalista baseia-se em concorrência e livre iniciativa. Não há uma forma de ensino ou um ensinamento oficial assim como não há uma cultura predestinada a submeter as outras e, por isso, lega-se à sociedade civil os destinos da educação e cultura. A concentração da informação por um ou poucos meios de comunicação representa um monopólio da palavra danoso à democracia, como se evidenciou na ditadura de 1964, que recebeu apoio das grandes empresas de comunicação do Brasil.

É preciso se observar esse pluralismo com o devido grão de sal porque boa parte dos direitos individuais trazidos pela sociedade capitalista foram engendrados aos interesses de uma classe social determinada, a burguesa, e há dificuldades notórias de sua universalização. O pluralismo partidário encontra óbice no financiamento privado das campanhas, onde as empresas despejam milhões de reais em candidatos desejando obter retornos ilegais ou imorais. As contratações coletivas de trabalho são prejudicadas pela manutenção constitucional da unicidade e do imposto sindical. É da natureza concentracionista do capitalismo que as grandes empresas destruam as pequenas. $\mathrm{O}$ ensino e a cultura estão deveras atrelados a interesses empresariais e uma meia dúzia de famílias concentra em si a propriedade de mais de $80 \%$ das empresas de comunicação no país. Além do quê, é notório que a família Marinho, por exemplo, tem muito mais liberdade de comunicação do que qualquer um que leia este escrito.

Porém, o que a Constituição pretendeu assegurar é a dignidade da pessoa humana, a liberdade de cada um em definir os caminhos a seguir. Não importa se essa definição será individual ou coletiva, importando apenas que haja a liberdade para defini-la. Em uma sociedade deveras complexa, é impossível e condenável que o Estado concentre o monopólio das definições do destino do país e o poder da democracia é aberto a que a sociedade civil possa participar dessas decisões. Por isso, a previsão dos institutos do referendo, plebiscito e iniciativa popular pelo art. 14 que poderia ser acrescida aos institutos acima em favor do pluralismo.

Uma teoria constitucional moderna tem que encarar o fato de que a tripartição de poderes encontra-se em via de esgotamento enquanto alternativa democrática. Uma distribuição de poderes no seio da sociedade faz-se necessária porque o Estado não consegue atender a todas as contradições e conflitos sociais, econômicos, políticos e jurídicos existentes. Além disso, a ideia centrada no lema "um homem, um voto" também é insuficiente porque resume as diferenças políticas à individualidade e cada vez mais os 
indivíduos agrupam-se em associações para defender seus direitos coletivamente. Assim, há que se contrapor a individualidade à coletividade para que se obtenha um ganho real de democracia.

Ronaldo Lima dos Santos caracteriza essas coletividades como agrupamentos intermediários, por encontrarem-se entre os indivíduos e o Estado, ou seja, entre a (pretensamente) individualidade máxima e a (pretensamente) coletividade máxima. Santos sugere que esses agrupamentos intermediários incorporar-se-iam na participação democrática em quatro esferas: administrativa, política, jurídica e judiciária. Pelos elementos apontados pelo autor, seria possível reduzir essa classificação às esferas política e jurídica.

A participação política dos agrupamentos intermediários ocorre quando estes atuam perante instâncias decisórias relativas às políticas públicas, gerais e/ou setoriais, ou relativas às conduções da administração da coisa pública. A participação jurídica ocorre com a possibilidade dessas coletividades atuarem na formulação de leis ou defender o ordenamento jurídico-positivo para promover a tutela dos direitos de seus representados ou além, de forma judicial ou extrajudicial.

Como exemplo da atuação política direta dos agrupamentos intermediários expresso pela Constituição, tem-se, por exemplo, a previsão do art. 29, XII de que os municípios serão regidos por leis orgânicas aprovadas mediante "cooperação das associações representativas no planejamento municipal". Isso significa que os interesses mediados pelas eleições de representantes eleitos pelo voto individual devem se concatenar com os interesses mediados por coletividades associadas em torno dos interesses relativos ao desenvolvimento do município a exemplo de associações de bairro, de defesa do transporte público, de conselhos de arquitetura e urbanismo etc.

Essa previsão de participação é expressa e direta, mas é possível que os agrupamentos intermediários atuem de forma indireta. Quando o governo federal convoca congressos temáticos para discutir políticas públicas para jovens, negros, mulheres, indígenas, educação, saúde, reforma agrária e um sem número de temas, as associações desenvolvem atuação de protagonismo na organização dos encontros, nos encaminhamentos aprovados e na fiscalização do cumprimento das demandas pelo poder público.

Em um encontro que debata políticas públicas para mulheres, por exemplo, é possível que uma mulher queira participar individualmente enquanto alvo das políticas a 
serem aprovadas ou enquanto pesquisadora da temática. Mas também é possível que uma organização que defenda os direitos das mulheres participe representando a sua coletividade, de forma que resta provado que a participação política dos agrupamentos intermediários não exclui a participação política dos indivíduos.

Da mesma forma, é possível que agrupamentos intermediários atuem indiretamente durante um plebiscito ou uma eleição. Associações civis, sindicatos, empresas, ONG's podem apoiar uma determinada candidatura ou proposta e apoiá-la abertamente visando influenciar o eleitorado.

O Conselho de Desenvolvimento Econômico e Social (CDES) criado pela Lei 10.638/03 poderia ser outro exemplo de incorporação dos agrupamentos intermediários à democracia brasileira porque, a despeito de seus integrantes serem nomeados pessoalmente, são majoritariamente oriundos de empresas, centrais sindicais e outras organizações.

Como exemplo de atuação jurídica dos agrupamentos intermediários tem-se a legitimidade para que associações possam representar seus associados judicial ou extrajudicialmente concedida pelo art. 5, XXI, a ampla legitimidade dos sindicatos defenderem seus representados individual ou coletivamente autorizada pelo art. $8^{\circ}$, III, a legitimidade das confederações ou entidade de classe de nível nacional para propor Ação Direta de Inconstitucionalidade prevista no art. 103, IX e a possibilidade de ajuizamento de dissídio coletivo preceituado pelo art. $114, \S 2^{\circ}$.

Em todos esses exemplos, as associações ou sindicatos podem atuar judicialmente em nome próprio na defesa de direitos alheios de seus associados ou representados. Isso é uma evolução jurídica porque possibilita aos agrupamentos intermediários um acesso à justiça outrora restrito às pessoas individualmente consideradas atuando em nome próprio. Se uma empresa desrespeita um direito positivado de todos os seus empregados, era necessário que cada empregado ingressasse com uma reclamação trabalhista, o que permitia que houvesse sentenças contraditórias e congestionava a já sobrecarregada Justiça do Trabalho. Agora, uma única ação pode ser ajuizada pelo sindicato em nome de todos os empregados, facilitando o acesso à justiça de todos e reduzindo o número de processos.

O pluralismo adotado pela Constituição, em especial o pluralismo jurídico, impõese na medida do desenvolvimento socioeconômico, notadamente a partir do pós-guerra. Os grandes conglomerados urbanos e a sociedade de massas oriundos da explosão demográfica levaram à perda de espaço da pessoalidade em detrimento da impessoalidade. 
Conflitos de interesses e de direitos ganharam dimensões tais que tornaram-se de inviável e desnecessária resolução individual.

Os conflitos adquiriram feição de massa: a luta dos sem terra, dos sem teto, a luta contra a violência à mulher, o combate ao racismo, a proteção ambiental, vários são os exemplos. Por consequência, a afirmação dos direitos caracterizou os agrupamentos sociais enquanto sujeitos de direito. Os direitos individuais relativos a todas as pessoas caminham agora ao lado de direitos das mulheres, dos negros, dos portadores de deficiência, dos consumidores, das crianças.

Esses novos sujeitos de direito trouxeram demandas que confrontam-se com o direito tradicional, liberal e individualista. Se há um direito comum e afirmado em relação a uma coletividade, nada mais natural que a garantia desse direito ocorra de forma também coletiva. E se o Estado não é onipotente e onipresente, há que se legar à sociedade civil organizada a construção e garantia de seus direitos, rompendo com o impossível monismo estatal.

Para que se cumpram com os objetivos estabelecidos pela ordem jurídicoconstitucional, faz-se necessário que esses novos sujeitos de direito assumam normatividade própria, concatenada com a normatividade estatal, mas autônoma, voltada para os protagonistas e beneficiários dos direitos.

(...) o direito dos grupos se preocupa com a funcionalização dos institutos jurídicos, direcionando-se para a eficácia das normas e dos institutos vigentes, por meio de uma prática normativa complementar, suplementar ou otimizadora de preceitos legais (Santos, 2009, p. 84).

Ou seja, a descentralização normativa não é só benéfica, é também necessária para que o Direito atinja os seus objetivos de solidificação das estruturas sociais. O Estado não é mais o único centro de poder porque há diversos centros de poder espalhados pela sociedade que existem de fato e atuam cotidianamente; reduzir o Direito ao Estado significaria ter um juiz em cada esquina. Uma sociedade democrática nos termos da Constituição deve dispor de centros de concreção do Direito, onde este é criado e garantido.

O direito estatal estabelece uma norma geral e sanciona os atos que o desrespeitem. O direito descentralizado (ou os direitos descentralizados?) sintetiza aspirações 
particulares, localizadas em coletividades determinadas. São baseados em consensos, não porque não sejam oriundos de conflitos, mas porque a composição dos conflitos cabe às partes conflitantes, mediada pela correlação de forças.

Nesse ínterim, pode-se dizer que o Direito do Trabalho é pluralista por natureza e o Direito Coletivo do Trabalho representa um salto qualitativo dentro do Direito. O movimento dos trabalhadores organizados em sindicatos forçou uma ruptura com os paradigmas jurídicos anteriormente adotados.

Nos primórdios do capitalismo industrial, tanto na Europa quanto no Brasil, os sindicatos eram proibidos pelo Direito por afrontarem o individualismo contratual pelo qual se erigiram os ordenamentos jurídicos modernos. O sujeito de direito era centrado no indivíduo, que assumia centralidade em uma sociedade de trocas. Este indivíduo poderia contratar livremente com outros indivíduos na compra de uma mercadoria, em um casamento, um aluguel, o que fosse.

Um trabalhador livre, então, poderia contratar com um capitalista uma relação de troca entre dois sujeitos de direito: um proprietário de sua força de trabalho e um proprietário das condições objetivas por onde o trabalho se realizaria. O assalariamento é uma compra e venda de uma mercadoria: um oferta o seu labor e o outro paga o preço deste labor sob a forma salário.

A partir do momento em que os trabalhadores percebem as suas péssimas condições de vida, com jornadas longas ao ponto de não conseguirem fazer mais nada e salários baixos ao ponto de não se alimentarem o suficiente para voltar ao trabalho no dia seguinte, percebem que essas são as péssimas condições de vida de todos os trabalhadores. Os contratos individuais de trabalho são-lhe desvantajosos e unem-se para contratar coletivamente visando obter melhores condições.

O direito liberal de então não permitia contratações que não fossem individualizadas pela sua necessidade em decompor a sociedade por indivíduos "livres". A primeira reação do direito é negar a mera possibilidade dos trabalhadores reivindicarem coletivamente e criminalizar os movimentos coletivos, tipificando tais movimentos nos códigos penais.

Porém, a luta sindical dos trabalhadores força o direito a adaptar-se e reconhecê-los enquanto sujeito coletivo de direito sob pena de desestabilizar o sistema de produção e reprodução capitalista. Assim, os sindicatos são juridicamente reconhecidos como sujeitos de direito e obtém o direito de contratar enquanto coletividade. 
As convenções e acordos coletivos são expressões plenas do pluralismo em geral e do pluralismo jurídico em particular. A possibilidade de estabelecer um acordo ou convenção entre um sindicato de empregados e uma empresa ou um sindicato de empresas é um direito de produzir direitos. A convenção ou acordo é norma jurídica constitucionalmente prevista produzida pelas partes contratantes e tem eficácia sobre toda a categoria representada pelo sindicato, inclusive entre os empregados não sindicalizados. A análise da teoria das fontes voltada ao Direito do Trabalho assim o demonstra.

O conjunto das normas jurídicas vigorantes em um dado Estado compõe o ordenamento jurídico estudado. A teoria das fontes estuda justamente a origem dessas normas. Maurício Godinho Delgado (2007, p. 138) afirma ser esse tema decisivo no Direito do Trabalho "por comportar um relevante elemento diferenciador desse segmento jurídico especializado perante os demais ramos existentes".

O Direito apresenta uma classificação geral em dois blocos de fontes: formais e materiais. As fontes materiais envolvem a dinâmica geral da luta de classes, as clivagens sociais e econômicas, enfim, as contradições e a correlação de forças da sociedade. O grau de desenvolvimento das forças produtivas, o grau de industrialização e urbanização, a existência de sindicatos fortes e representativos, uma democracia de fato consolidada, estruturas estatais em funcionamento, o nível de emprego, tudo isso são fatores que influenciam nas fontes materiais do direito.

Foi observado anteriormente como o Brasil apresentou duas correlações de forças diferentes desde o advento do Plano Real. A ascensão ao poder de um partido político prócapital comprometido com reformas econômicas impopulares e contracionistas aponta para um momento desfavorável à organização sindical e os trabalhadores tem os seus direitos atacados. Por outro lado, a ascensão ao poder de um partido político oriundo do movimento sindical com sua representação política fortemente vinculada à luta dos trabalhadores aponta para um ambiente favorável ao avanço da pauta sindical.

As fontes formais de direito conformam o objeto de estudos da ciência do direito, o que poderia ser encarado como a própria negação das fontes materiais. Os juristas pretendem-se imparciais, equidistantes das partes, abdicam de aprofundar seus conhecimentos acerca das fontes materiais e reduzem seu campo de estudos às fontes formais, o que é lamentável porque impede a compreensão real do fenômeno jurídico, que não está apartado das demais estruturas da sociedade. 
As fontes formais representam "o fenômeno de exteriorização final das normas jurídicas, os mecanismos e modalidades mediantes os quais o Direito transparece e se manifesta" (DELGADO, 2007, p. 141). Apresentam o mandamento do direito expressamente, a norma jurídica aparece pronta e acabada.

As fontes formais podem ser autônomas ou heterônomas. Se os destinatários da norma não participam da produção da regra jurídica, será heterônoma a fonte; se os destinatários participam da produção, são autônomas as fontes. A enumeração das fontes que segue é sugerida por Delgado (2007).

A principal fonte formal heterônoma é a Constituição. Esta é a fonte normativa prevalente no ordenamento jurídico, conferindo validade e eficácia a todas as demais fontes. A constituição está no topo da pirâmide do ordenamento e qualquer norma jurídica, para ter validade, deve estar em acordo à constituição. A Constituição Federal de 1988 trás as regras e princípios gerais do direito brasileiro e absorveu diversos institutos do Direito do Trabalho, que deve se adequar à Carta Magna.

A lei é uma regra jurídica geral, abstrata, impessoal, obrigatória cuja eficácia baseia-se no poder coercitivo estatal. No Brasil, as leis relativas ao Direito do Trabalho devem ser aprovadas pelo Congresso Nacional e promulgada pela Presidência da República. A Consolidação das Leis do Trabalho é a principal lei deste ramo do direito no Brasil, embora tenha sido outorgada pelo então Presidente, o que era compatível com a Constituição da época.

Tratados são fontes oriundas de organismos multilaterais internacionais. A Organização Internacional do Trabalho denomina seus tratados de convenções que, para que vijam em um determinado país, dependem da ratificação deste. O Brasil é signatário de diversas convenções da OIT e estas podem assumir a condição de emenda constitucional desde que versem sobre direitos humanos e sejam aprovadas por 3/5 dos congressistas em dois turnos em cada casa (Câmara e Senado).

Regulamento normativo é um decreto emitido pelo Poder Executivo que visa especificar o conteúdo de uma lei. Embora a Constituição tenha restringido a atuação do Executivo nas relações de trabalho, o Direito do Trabalho apresenta diversos decretos de rotineira aplicação a exemplo do Decreto 95.247/87, que regulamenta o vale-transporte instituído pela Lei 7.418/85.

Portarias, avisos, instruções e circulares também são atos administrativos e podem adquirir caráter heteronômico de fonte jurídica se expressamente previsto por lei. É o caso 
dos arts. 192 e 193 da CLT que legam a uma portaria do Ministério do Trabalho e Emprego a especificação das atividades consideradas perigosas ou insalubres a título de pagamento de adicional de periculosidade ou insalubridade.

A sentença normativa seria mais uma fonte formal heteronômica do Direito do Trabalho brasileiro. Se as negociações coletivas chegam a um impasse, é facultado às partes negociantes ajuizar dissídio coletivo invocando o Poder Normativo da Justiça do Trabalho. O resultado é uma sentença normativa, que tem "corpo de sentença e alma de lei”. É uma sentença porque proferida pelo Poder Judiciário pondo termo ao processo, mas não aplica a norma geral ao caso concreto; a sentença normativa cria norma jurídica para as partes do dissídio, assume a função de acordo ou convenção coletiva de trabalho.

Delgado não situa aqui, mas a jurisprudência pode ser compreendida enquanto fonte formal heterônoma. Jurisprudência é a interpretação reiterada das normas jurídicas pelos tribunais. No Direito do Trabalho, é muito comum fundamentar um argumento por uma súmula do TST por exemplo.

Em termos de fontes formais autônomas do Direito do Trabalho, as convenções e acordo coletivo destacam-se. Trata-se de dois dos mais importantes institutos deste ramo do direito e lhe conferem singularidade. Se formalmente despontam como um contrato, um ajuste de vontades, substancialmente aparentam uma lei, uma vez que são normas jurídicas a serem observadas para toda a base representada pelo sindicato contratante. A absorção do acordo ou convenção coletiva pelo direito trouxe-lhe modificações significativas conforme testemunham as palavras de Maurício Godinho Delgado (2007, p. 159) sobre estas figuras jurídicas: "é que elas somente se compreendem em função da noção de ser coletivo (...). Com isso, fazem contraposição à hegemonia incontestável do ser individual no estuário civilista preponderante no universo jurídico".

O contrato individual de emprego é o ajuste de vontades entre empregado e empregador e também situa-se aqui. As disposições constantes no contrato referentes ao salário a ser pago, as tarefas a serem executadas e outras cláusulas é mediado pela contratação coletiva e pela legislação, mas se insere no estudo das fontes porque vincula os contratantes e as cláusulas que beneficiam o empregado aderem ao seu contrato de forma perene.

Usos e costumes são igualmente mencionados pelo autor supra como fonte formal heterônoma. O uso simbolizaria a prática habitual adotada em uma relação jurídica determinada, enquanto o costume seria uma prática habitual adotada amplamente em uma 
empresa, região outro espaço maior. Ou seja, o uso só se aplicaria a um ou mais indivíduos determinados, fixos, e o costume tem aplicação geral no ambiente.

Ao lado das fontes autônomas e heterônomas, Delgado sugere que existiriam algumas fontes especiais de difícil enquadramento na dicotomia autonomia $\mathrm{x}$ heteronomia. O regulamento empresarial, por exemplo, é rechaçado pela jurisprudência enquanto fonte autônoma porque significaria uma vontade unilateral do empregador oriunda do seu poder diretivo. O laudo proferido em sede de arbitragem possui um componente heterônomo pelo fato de ser produzido por um terceiro, mas possui um componente autônomo por ser este terceiro designado livremente pelas partes.

O fundamental a observar nesse estudo de fontes é a comprovação de que a ordem jurídico-positiva brasileira aderiu em diversos momentos ao pluralismo enquanto expressão da democracia. E o Direito do Trabalho em particular, pluralista por natureza, o atesta. Há normas jurídicas trabalhistas oriundas de acordo de vontades entre o empregado e o empregador, entre o acordo de vontades coletivas entre o sindicato de empregados e as empresas organizadas em sindicato patronal ou individualmente, dos usos e costumes, do Poder Executivo, do Poder Legislativo, do Poder Judiciário, de organismos internacionais. Há uma pluralidade de centros de produção de normas jurídicas considerável que compõe a totalidade do Direito do Trabalho, em consonância com a pregação democrática da Constituição.

Como nem tudo são flores, constata-se que essa pluralidade pode ser excessiva quando observadas as fontes formais heterônomas estatais. A autonomia privada coletiva é celebrada por significar um avanço democrático nas relações de trabalho e uma intervenção estatal excessiva expressa uma sociedade autoritária. A maior ou menor regulação estatal e a maior ou menor autonomia privada coletiva são polos de tensão do equilíbrio em que se baseia o Direito do Trabalho e definem o caráter aberto ou inflexível da sociedade.

Baseado nessa tensão, Delgado (2007, p. 1373 e ss.) classifica três padrões de regulação das relações de trabalho: o modelo de normatização autônoma e privatística, o de normatização privatística subordinada e o de subordinação estatal.

A Inglaterra, berço do capitalismo industrial, e os EUA, maior potência capitalista mundial, seriam os dois exemplos do modelo autônomo e privatístico. A ideologia liberal, o individualismo e o contratualismo desses países faz com que a regulação das condições 
do trabalho seja legada exclusivamente ao jogo do mercado, legitimando o conflito entre os particulares.

No modelo privatístico subordinado, adotado por boa parte da Europa continental, o Estado delimita o campo de atuação das partes, mas cabe a essas a dinâmica criativa da contratação coletiva. Assim, a criatividade dos particulares define a regulamentação das relações entre capital e trabalho, mas isso ocorre de forma heteronomicamente regulada. Esse modelo é o mais próximo do defendido pela OIT.

O modelo de normatização subordinada estatal rejeita os conflitos entre capital e trabalho e não admite seus desdobramentos autônomos. Caberia prioritariamente ao Estado o papel de regulador dos interesses, absorvendo as contradições entre empregados e empregadores e dando-lhes solução heteronômica. Esse modelo baseia-se nas experiências fascistas da Alemanha e Itália do início do século XX e influenciou fortemente a legislação brasileira.

\begin{abstract}
A minuciosa legislação estatal institui formas e conteúdos de solução de conflitos, procurando se antecipar (ou sufocar), através de uma cuidadosa operosidade legislativa, às alternativas jurídicas que se poderiam, privadamente, estabelecer. Nesse padrão jurídico, a elaboração estatal do Direito do Trabalho consubstancia um processo de restringida participação da sociedade civil e cria uma dinâmica cujas linhas mestras se caracterizam por assegurar o contínuo impedimento a essa participação (DELGADO, 2007, p. 1375).
\end{abstract}

A estrutura do Direito do Trabalho brasileiro foi justamente criada com o intuito de esvaziar o papel dos sindicatos e impedir o conflito coletivo de trabalho. Em troca, instituiu-se uma legislação trabalhista individual deveras minuciosa e o desrespeito a essa legislação seria resolvida perante uma justiça especializada em conflitos trabalhistas individuais. Assim, canaliza-se os permanentes conflitos entre capital e trabalho ao Estado, impedindo ou dificultando a autocomposição e a criação de normas jurídicas pelas partes conflitantes.

Essa estrutura engendrada nas décadas de 30 e 40 do século passado era compatível com o ordenamento jurídico da época, fechado, autoritário e antidemocrático. O ordenamento jurídico elaborado ao fim da ditadura de 1964 tem como base a Constituição de 1988, pluralista por natureza conforme viu-se anteriormente. Logo, há uma incompatibilidade notória entre uma estrutura infraconstitucional de lógica monista, estatista e autoritária (a CLT sequer foi aprovada pelo Poder legislativo, tendo sido 
outorgada por Decreto-Lei do Poder Executivo) e uma constituição pluralista, aberta, democrática, que confere aos particulares a possibilidade de criação de normas jurídicas ante a impossibilidade de o Estado tudo saber e resolver.

Contudo, a Constituição Federal de 1988, contrariando os anseios populares dos trabalhadores, não afastou as contradições entre seus objetivos e a estrutura trabalhista anterior, negou a liberdade almejada pelo movimento sindical e manteve os pilares autoritários da CLT calcados na unicidade, no imposto sindical e no Poder Normativo da Justiça do Trabalho.

A Carta Magna pretendeu tão somente mitigar os efeitos autoritários advindos da CLT e trouxe alguma flexibilização da interferência estatal nos sindicatos, embora não tenha atacado o centro do problema. Entre os arts. $7^{\circ}$ e $11^{\circ}$, trouxe algumas modificações que apontam para alguma liberdade sindical.

$\mathrm{O}$ art. $7^{\circ}$, XXVI reconheceu expressamente as convenções e acordos coletivos enquanto direito dos trabalhadores. O mesmo artigo conferiu poderes aos acordos e convenções para reduzir salários (inc. VI), estabelecer compensação de horários (XIII) e negociar a jornada de trabalho em turnos ininterruptos. Na doutrina, há quem defenda que esses três últimos incisos citados fortaleçam o poder de negociação dos sindicatos; mas, uma análise da correlação de forças da constituinte e da hegemonia neoliberal desregulamentadora que se seguiu sugerem que o objetivo desses incisos era mesmo de flexibilização constitucional daqueles que talvez sejam os mais importantes direitos individuais do trabalho - remuneração e jornada.

O contraditório art. $8^{\circ}$ preceitua a livre associação profissional e sindical logo em seu caput, mas manteve a unicidade imposta à categoria profissional (inc. II), o que é um absurdo contrassenso. Entretanto, vedou a interferência estatal na fundação e organização sindical (inc. I), o que pode ser apontado com causador de três efeitos visíveis. O primeiro é a impossibilidade de intervenção nos sindicatos, prática corriqueira durante a ditadura de 1964. Dirigentes sindicais eram destituídos e pelegos eram nomeados pelo governo com o intuito de domesticar os sindicatos e permitir o crescimento da economia concentrando os lucros para os empresários. O segundo é a não recepção pela Constituição do Quadro de Atividades e Profissões do Ministério do Trabalho conforme previsto pelo art. 577 da CLT e que definia as categorias profissionais em torno das quais os sindicatos se organizariam. O terceiro é a invalidação das minuciosas normas previstas pela CLT, mormente em seus arts. 612 e 614, referentes a obrigações formais dos sindicatos para aprovação das 
convenções e acordos, a exemplo da qualificação do quórum das assembleias e obrigação do depósito do acordo no Ministério do Trabalho. A Seção de Dissídios Coletivos do TST chegou a elaborar Orientações Jurisprudenciais atestando a validade dessas normas celetistas, mas tais OJ's foram canceladas em nome da melhor interpretação constitucional referente à matéria.

O contraditório art. $8^{\circ}$ da $\mathrm{CF} / 88$ preceituou ainda a ampla competência para os sindicatos representarem suas bases administrativa e judicialmente (inc. III). Tal ampliação de competência autoriza os sindicatos a ingressarem com ações em nome próprio em defesa dos interesses individuais ou coletivos da categoria. E estabeleceu a obrigatoriedade da participação dos sindicatos nas negociações coletivas (inc. VI), o que levantou uma polêmica. Há vozes doutrinárias que entendem pela recepção constitucional do art. $617, \S$ $1^{\text {o }}$ celetista, que afirma a possibilidade de federações e confederações celebrarem acordo coletivo perante a omissão do sindicato da categoria. Contudo, a obrigatoriedade da participação sindical prevista pela Constituição supõe que a melhor interpretação é a que nega tal possibilidade. Federações e confederações, então, só poderiam celebrar convenções coletivas na inexistência de sindicato da categoria.

$\mathrm{O}$ art. $9^{\circ}$ constitucional assegura o direito de greve, reservando ao sindicato a oportunidade e conveniência de realiza-la, norma fundamental para a defesa dos interesses dos trabalhadores porque, muitas vezes, as empresas ou os sindicatos patronais endurecem nas negociações e tornam-se irredutíveis na concessão de benefícios. A legislação trabalhista é o patamar mínimo contratual e todas as cláusulas convencionais são benefícios a mais conquistados pelos sindicatos. Logo, são esses que tem interesse em acordar ou convencionar para melhorar suas condições de vida e de trabalho. Se a representação patronal nega-se a negociar, a greve é o mecanismo preferencial de pressão.

$\mathrm{O}$ art. 10 da $\mathrm{CF}$ assegura a participação dos trabalhadores em órgãos públicos deliberativos de seus interesses trabalhistas e previdenciários, o que é um incentivo à chamada concertação social. $\mathrm{O}$ art. 11 assegura a eleição de um representante pelos empregados em empresas com mais de 200 empregados. Essa norma poderia representar a concretização da organização por local de trabalho tão desejado pelo movimento sindical, mas é de pouca eficácia e estabelece uma limitação quantitativa indevida e restritiva.

À luz dos preceitos pluralistas da Constituição e das inovações trazidas pela Carta Magna, pode-se analisar à inteireza a caracterização legal das convenções e acordos coletivos de trabalho. Conforme já observado, convenções e acordos coletivos são o 
resultado de negociações coletivas envolvendo sindicatos de trabalhadores e sindicatos patronais ou empresas individualmente consideradas. Tais diplomas normativos estabelecem a regulamentação das condições de trabalho em seu âmbito de incidência, uma vez que a legislação autoriza as partes a criar normas jurídicas que resolvam os conflitos coletivos e as diferenças de interesses. Diz-se que tem corpo de contrato e alma de lei por representarem um ajuste de vontades similar a um contrato e criarem normatizações gerais, abstratas e impessoais similares a uma lei perante a categoria representada. A caracterização que segue baseia-se na obra doutrinária de Maurício Godinho Delgado.

A legitimidade para a contratação coletiva no Brasil cabe, pelo lado dos empregados, ao sindicato da categoria, cuja participação é obrigatória. Na ausência de sindicato, a legitimidade poderá ser transferida à federação da respectiva categoria e, na ausência desta, à confederação. $\mathrm{O}$ entendimento jurisprudencial atual é pela ilegitimidade das centrais sindicais e pela impossibilidade de convenção ou acordo celebrados por trabalhadores diretamente com as empresas. Há que se frisar que essas vedações podem ser relativizadas porque a CF assegurou aos trabalhadores o direito ao acordo ou convenção coletiva. Se uma determinada categoria não tiver sindicato, federação nem confederação, como esse direito será garantido? Como a lei que reconheceu as centrais sindicais data de 2008 e há uma ADIN no Supremo a questionar essa lei, é possível que essa discussão evolua para uma liberdade maior. Pelo lado patronal, as empresas podem negociar diretamente um acordo coletivo, mas só o sindicato da categoria econômica poderá celebrar uma convenção coletiva.

O conteúdo dos instrumentos coletivos negociais abarca regras jurídicas e cláusulas obrigacionais. As primeiras são a razão da existência das negociações coletivas e representam as cláusulas que geram direitos e obrigações nas condições objetivas de trabalho. Integram-se aos contratos individuais de emprego e tem validade geral perante a categoria cujo sindicato é signatário. Já as cláusulas obrigacionais tem presença reduzida e vinculam apenas as partes diretamente convenentes, o sindicato de empregados e a empresa ou sindicato patronal. São cláusulas mais instrumentais, como a obrigação da empresa em liberar a lista com os nomes dos empregados.

Essas regras jurídicas são de ampla criatividade das partes. Podem referir-se à estipulação salarial, ao valor das gratificações, à duração do trabalho, às hipóteses de estabilidade no emprego, afastamento previdenciário dentre outras. Em obra datada de 1914, Evaristo de Moraes traz a seguinte definição de sindicato: 
É uma associação de trabalhadores da mesma profissão ou especialidade ou de profissões conexas e similares, que tem por fim defender seus interesses materiais e morais, perante os patrões e os poderes públicos, intervindo nas condições do trabalho, na fixação do salário, na regulamentação das horas de atividade profissional, na forma de aprendizagem, finalmente, em tudo que diga ao bem-estar dos associados (MORAES, 1998, p. 98).

Interessante notar dessa passagem que o autor já naquela época percebia que era escopo dos sindicatos defender os interesses morais dos seus associados ao lado dos interesses materiais. Muito antes do instituto do dano moral ser reconhecido pelo direito brasileiro, o autor já o afirmava, compreendendo que as relações de trabalho não se resumem às obrigações patrimoniais, mas são também relações pessoais e os direitos da personalidade devem ser tutelados. Além disso, ao utilizar o verbo "intervir" referente às relações de trabalho, o autor sugere que o papel primordial do sindicato é participar da regulamentação das condições de trabalho, impondo a autonomia privada coletiva.

Por se tratar de instrumento normativo, os acordos e convenções coletivas são formais por natureza e as formalidades devem ser observadas. São elaborados por escrito, devidamente publicados e devem observar os rituais estipulados nos estatutos dos sindicatos referentes à aprovação em assembleia, quórum assemblear e os procedimentos das discussões e deliberações. Ressalte-se que as minúcias celetistas para o tema não foram recepcionados pela Constituição, uma vez que é vedado ao Poder Público interferir na organização sindical.

A vigência do acordo ou convenção inicia-se três dias após o depósito do instrumento coletivo no Ministério do Trabalho e Emprego, nos termos do art. 614, $\S 1^{\circ}$ da CLT. Essa norma contradiz a vedação constitucional da interferência do Poder Público, mas o TST inclina-se por sua validade, conforme demonstra a OJ 34 da SDC. Carece de opinião definitiva do STF. Por tratar-se de documento comum às partes, a cópia simples basta a título de prova em juízo se não impugnado seu conteúdo nos termos da OJ 36 da SDI - I do TST.

A duração do acordo ou convenção coletiva não pode superar dois anos conforme o art. 614, § $3^{\circ}$ da CLT, mas a prática da maioria dos sindicatos é contratar com duração de um ano apenas. Essa limitação temporal também é constitucionalmente questionável uma vez que restringe norma constitucional por norma infraconstitucional. 
O art. 615 celetista fala que prorrogação, revisão, denúncia, revogação ou extensão obedecem aos mesmos requisitos da celebração original do diploma coletivo.

Deve-se recordar que o Direito do Trabalho rege-se pelo princípio da norma mais favorável ao empregado e esta é a forma de resolução quando houver contradição entre diplomas negociais coletivos. Este princípio é mediado pela teoria do conglobamento, que afirma que a comparação para saber qual a norma mais favorável deve ser feita compreendendo a totalidade das normas em apreço. Se um acordo coletivo contradiz uma convenção coletiva, será observado qual o mais favorável ao empregado entre o acordo e a convenção, não se podendo analisar cláusula por cláusula.

Nos termos da legislação brasileira, a convenção coletiva e o acordo coletivo de trabalho são os dois modelos de negociação com vistas ao ajuste das condições de trabalho autônomo entre empregados e empregadores. Entretanto, o direito brasileiro é deveras restritivo e impeditivo da liberdade sindical plena e não se pode olvidar de outras figuras que não estão previstas pelo direito positivo, mas são de inegável impacto normativo.

A chamada concertação social é uma prática negocial coletiva que envolve trabalhadores, empresários e o governo. O Estado aqui pode desenvolver atividade típica de mediação, mas é parte interessada e diretamente envolvida. Os temas abarcados, em regra, versam sobre questões de natureza macroeconômica que afeta as empresas e os empregados ou sobre questões trabalhistas propriamente ditas. É mais comum nos países de capitalismo avançado, mormente na Europa, mas tem importância crescente no Brasil após a democratização.

A concertação social, por não ser prevista formalmente pelo direito, não exibe uma formalidade a priori e depende do impulso das partes. Há três grandes exemplos ocorridos no Brasil nos últimos vinte anos: as câmaras setoriais automotivas, a lei que estabelece o cálculo de correção do salário mínimo e o acordo para regular o trabalho na construção civil.

Em 1992, Governo Collor, a crise social explosiva proporcionada pelo baixo crescimento econômico, inflação alta e abertura comercial abrupta demandou soluções inovadoras. Uma delas foram as chamadas câmaras setoriais da indústria automobilística. Protagonizada pela categoria metalúrgica, o Governo Federal, os empresários automotivos e os sindicatos de metalúrgicos de São Bernardo e Diadema, Santo André e Betim assinaram um acordo que previa a redução de $22 \%$ dos valores dos automóveis mediante redução de impostos e dos lucros das empresas. Tal acordo visava esvaziar o estoque de 
cerca de 30 mil veículos produzidos pelas montadoras que encontravam-se nos pátios parados de forma que não houvesse demissões nem redução salarial. Compuseram as partes atendendo aos interesses de todos: o governo queria aquecer a economia, as empresas queriam vender suas mercadorias e os trabalhadores queriam manter seus empregos intactos.

No Governo Lula, as centrais sindicais negociaram com o governo uma política de valorização permanente do salário mínimo que foi apresentado pela CUT à época como "o maior acordo coletivo do mundo". A prática foi executada desde então através de medidas provisórias até que aprovou-se no Congresso a Lei 12.382/11, prevendo a manutenção do acordo até o ano 2015. Por esta, a variação anual do salário mínimo seria a composição do índice inflacionário do ano anterior medido pelo Índice Nacional de Preços ao Consumidor (INP-C) do IBGE (art. $2, \S 1^{\circ}$ ) somado ao crescimento do PIB de dois anos antes (art. $2, \S$ $4^{\circ}$ ). Ou seja, haverá anualmente um reajuste real correspondente ao crescimento da economia nacional. $\mathrm{O}$ art. $3^{\circ}$ da referida lei prevê que decreto do executivo estabelecerá os valores nominalmente, norma cuja constitucionalidade foi questionada e declarada pelo STF.

No Governo Dilma, foi elaborado um acordo denominado Compromisso Nacional para Aperfeiçoar as Condições de Trabalho na Indústria da Construção. São signatários o Governo Federal através da Secretaria-Geral da Presidência da República e do Ministério do Trabalho e Emprego, o Sindicato Nacional da Indústria da Construção Pesada, a Câmara Brasileira da Indústria da Construção, a CUT, a Força Sindical, a CTB, a CGT, a NCST e a UGT. O acordo foi firmado em $1^{\circ}$ de março de 2012 com vigência até 31 de dezembro de 2014. Seu impacto é considerável, haja vista tratar-se da categoria que mais sofre com acidentes de trabalho, inclusive fatais, e uma das que mais cresce em termos de geração de empregos, impulsionado por investimentos governamentais. Seu conteúdo versa sobre recrutamento, pré-seleção e seleção com vistas à contratação de trabalhadores para obras de construção, formação e qualificação de mão-de-obra, saúde e segurança no trabalho, representação sindical no local de trabalho, condições de trabalho e relações com a comunidade.

Esses três exemplos ilustram bem que a concertação social cresce quantitativa e qualitativamente no país, somando-se aos institutos coletivos legais já existentes e apontando para a realização da liberdade sindical e a vocação contratual coletiva dos sindicatos. Não é coincidência esses exemplos terem ocorrido após o período de 
redemocratização; em tempos autoritários, as negociações coletivas são reprimidas e sufocadas e só podem realizar-se em sociedades abertas, democráticas, plurais.

A ordem democrática pluralista e aberta consagrada na Constituição Federal favorece as negociações coletivas. Contudo, um gravíssimo entrave às negociações manteve-se na ordem jurídico-constitucional: a unicidade sindical imposta por lei na base territorial não inferior ao município e o imposto sindical. O art. $8^{\circ}$, II e IV, da CF manteve a carapaça corporativa celetista que desautoriza falar em liberdade sindical no Brasil, enfraquece a organização sindical e impede a autocomposição dos conflitos pelas partes.

Ao agir dessa forma, a Assembleia Constituinte não avançou em direção à liberdade sindical compatível com o espírito geral da Constituição, uma vez que a espírito da CLT é autoritário e corporativo. O tímido avanço experimentado, a vedação à intervenção estatal na organização e gestão dos sindicados, agravou o problema.

Conforme explanado por Maria Silvia Portella de Castro, o modelo de Estado adotado a partir de 1930 calcava-se em uma "concepção hierárquica e orgânica da sociedade". De clara inspiração fascista, esse Estado estabeleceu um sistema de relações entre capital e trabalho voltado à cooperação e solidariedade das partes em nome dos interesses gerais da nação, de forma a se assegurar "um contato institucionalizado entre ambos promovido pela intervenção do Estado" (CASTRO, 2001, p. 108). Assim, o Estado intervia pesadamente evitando os conflitos inerentes ao modo de produção capitalista, estatizando os sindicatos existentes e proibindo o direito de greve. Os trabalhadores não mais poderiam organizar livremente seus sindicatos, pois estes agora pertenceriam ao Estado e cumpririam funções e objetivos estatais. Tal é o espírito celetista.

O Título V da CLT regulava minuciosamente a intervenção estatal nos sindicatos, do art. 511 em diante. Para que uma entidade sindical adquirisse personalidade jurídica e fosse aceita a sua existência, deveria solicitar ao Ministério do Trabalho que expedisse a chamada Carta Sindical no caso de sindicato (art. 520) e federação (art. 537, § $2^{\circ}$ ); no caso de confederações, a investidura ocorria mediante decreto presidencial (art. 537, $\S 3^{\circ}$ ).

A Carta Sindical era o diploma que conferia reconhecimento estatal à existência legal do sindicato. Especificava a base territorial e a categoria representada e sua expedição dependia da observância a uma série de pré-requisitos determinados pela CLT, a exemplo da reunião de $1 / 3$ dos integrantes da categoria e o exercício de cargos da diretoria por brasileiros (art. 515). 
$\mathrm{O}$ art. 516 da CLT estabelecia a unicidade sindical afirmando que não seria reconhecido mais de um sindicato da mesma categoria em uma mesma base territorial. Essa base territorial poderia ser territorial, municipal, intermunicipal, estadual, interestadual e, excepcionalmente nacional (art. 517).

A unicidade sindical era um ponto nevrálgico para o Estado corporativista por permitir o controle dos sindicatos. Para isso, era necessário definir os pontos de referência dessa unidade artificialmente imposta e isso foi feito através do enquadramento sindical e da base territorial.

José Francisco Siqueira Neto (2001, p. 93) anota que o enquadramento era "a moldura de encaixe definida pelo Estado para ajustar os agrupamentos de acordo com o tipo de profissão e atividade econômica e dar-lhes uma feição sindical". O governo afirmava que a estipulação das categorias, profissionais e econômicas, tinha base científica; porém, o fato é que expressavam a ideologia fascista da inexistência de classes sociais. Fragmentava-se a classe trabalhadora e estabeleciam-se as categorias a representar a produção nacional.

Já a base territorial era o espaço geográfico que circunscrevia a atuação do sindicato e preferia-se a base municipal. Para Siqueira Neto (2001, p. 94), unicidade, enquadramento e base territorial eram os instrumentos de dominação dos sindicatos pelo Estado e completavam-se mutuamente. A unicidade perde seus pontos de referência sem o enquadramento e a base territorial e o enquadramento e a base territorial perdem a importância corporativista sem a unicidade.

A CLT define categoria profissional (de empregados) pela "similitude de condições de vida oriunda da profissão ou trabalho em comum, em situação de emprego na mesma atividade econômica ou em atividades econômicas similares ou conexas" (art. 511, § $2^{\circ}$ ). Ou seja, a categoria de trabalhadores era definida pela similitude laboral vinculada a empregadores de atividades econômicas idênticas, similares ou conexas. Significa isso que, independente da função desempenhada pelo empregado, quem trabalha em uma indústria metalúrgica é metalúrgico, quem trabalha no serviço hoteleiro é hoteleiro, quem trabalha em banco é bancário e assim por diante.

A exceção a essa definição são as chamadas categorias profissionais diferenciadas, definidas pelo art. 511, $\S 3^{\circ}$ como aquelas "profissões ou funções diferenciadas por força de estatuto profissional especial ou em consequência de condições de vida singulares". Estas compõem os sindicatos horizontais cujos membros podem atuar nas mais diversas 
empresas a exemplo de advogados, engenheiros, músicos, jornalistas. Identificam-se por seu ofício e pela existência de norma jurídica que lhes regule as atividades profissionais especificamente.

As categorias profissionais eram discriminadas por um Quadro de Atividades e Profissões expedido pela Comissão de Enquadramento Sindical. Como a Constituição vedou a interferência estatal nos sindicatos, esse Quadro foi extinto e não cabe mais ao Estado enquadrar as categorias a serem sindicalizadas. Agora, os sindicatos tem autonomia para estabelecer sua própria categoria independente de um enquadramento estatal que não mais existe.

Essa aberração que visa mesclar liberalismo (fim do enquadramento pelo Estado) com corporativismo (unicidade e monopólio) permitiu uma fragmentação ainda mais absurda dos sindicatos. Ora, se não há mais um enquadramento deliberado pelo Estado estipulando quais são as categorias profissionais, sindicatos podem ser criados e desmembrados de outros e isso tem acontecido no país de forma sistemática. Ainda há a obrigatoriedade de haver a discriminação da categoria representada, mas essa categoria cabe ao sindicato definir. O único limite é a municipalidade enquanto base territorial mínima. A pulverização de entidades acarretada pela Constituição é tão absurda que, segundo o presidente do TST, há cerca de 14.000 sindicatos no país e 105 novos pedidos por mês para criação de novas entidades ${ }^{1}$ !

Um número tão elevado de sindicatos não pode ser benéfico ao movimento sindical. A maior parte desses novos sindicatos criados após a Constituição é fruto do desmembramento de outros sindicatos, fragmentando ainda mais as categorias e enfraquecendo a luta obreira. Muitos inclusive foram criados pelas terceirizações em larga escala ocorridas a partir dos anos 90. Só que a unicidade não é o único fator que explica tamanha pulverização sindical. "A unicidade sindical obrigatória, que levou ao monopólio da representação no Brasil, continua propiciando, em conjunto com o imposto sindical, a perpetuação de sindicatos 'de carimbo', ou seja, sem qualquer representatividade”, afirma Antônio Moreira de Carvalho Neto (2001, p. 70).

O imposto sindical é a fonte de financiamento criada pelo corporativismo para sustentar as entidades sindicais. Ora, se o Estado literalmente criava os sindicatos, estabelecendo os critérios de agregação de trabalhadores, o modo de financiamento, as funções e objetivos, precisava também criar um mecanismo tão autoritário quanto de

\footnotetext{
${ }^{1}$ http://www.conjur.com.br/2011-dez-18/presidente-tst-brasil-estrutura-sindical
} 
sustentação financeira das entidades. Estabeleceu, então, um imposto, uma fonte de custeio parafiscal, recolhida compulsoriamente de todos os empregados da base sindical, mesmo os não filiados. Uma verdadeira agressão.

O imposto sindical foi rebatizado pelos militares para contribuição sindical para ocultar o seu verdadeiro caráter. Sua regulamentação minuciosa abrange os arts. 578 a 610 da CLT, a maioria invalidados pela nova ordem constitucional. A CLT detalhava até mesmo a gestão dos recursos recolhidos compulsoriamente dos empregados.

O imposto sindical é descontado na folha do trabalhador todo mês de março e corresponde a um dia de trabalho. É tamanho o seu despropósito que é imposto pelo Estado e recolhido pelas empresas para financiar uma organização sindical. Além de não encerrar tal instituto, a Constituição instituiu uma nova contribuição para financiar agora a cúpula do sistema: a contribuição confederativa. Prevista pelo art. $8^{\circ}$, IV, a contribuição confederativa deve ser aprovada em assembleia e não é descontado de empregados não sindicalizados segundo entendimento jurisprudencial.

As contribuições acima convivem com mais duas modalidades de financiamento dos sindicatos. O art. 513, e) da CLT trata genericamente da contribuição assistencial, cuja aprovação é deliberada em assembleia e muitas vezes consta na convenção ou acordo coletivo. Por fim, as mensalidades são pagas pelos associados do sindicato livremente, sendo essa a fonte de custeio mais importante dos sindicatos representativos por ser a mais legítima, uma vez que livremente estipulada pela categoria.

A possibilidade de livre (ou quase) criação e desmembramento de sindicatos que monopolizam a representação da categoria encontrou um aliado perfeito no imposto sindical. Se esta atualmente chamada contribuição sindical é recolhida compulsoriamente dos empregados filiados ou não ao sindicato, criar um sindicato virou um grande negócio porque a) não tem concorrência, uma vez que apenas um sindicato pode existir em uma mesma categoria e b) o financiamento é uma imposição estatal descontada em folha, não há risco de não pagamento. "O casamento da unicidade sindical obrigatória e do imposto sindical é inimigo de morte da representatividade do sindicalismo brasileiro", conforme atesta Carvalho Neto (2001, p. 70).

A manutenção constitucional desses dois institutos corporativistas permitiu a proliferação de entidades sindicais de nenhuma representatividade, força ou capacidade organizacional. Um sindicato não precisa mostrar serviço para recolher o imposto, basta apenas a sua existência e tem-se uma fonte de inesgotável de dinheiro arrancado do bolso 
dos trabalhadores brasileiros. Estes sindicatos são comumente denominados sindicatos de fachada, de cartório ou de carimbo justamente porque não existem para defender os trabalhadores, existem apenas para arrecadar o imposto sindical.

Isso fere de morte as negociações coletivas. Uma convenção ou um acordo coletivo dependem da existência ativa e vibrante de sindicatos combativos, representativos de sua base, sindicatos que contam com a participação dos trabalhadores quando convoca uma assembleia, uma greve, uma passeata, uma eleição. A vitalidade democrática dos sindicatos é pré-requisito material para a contratação coletiva.

Contudo, o que se vê no país é a proliferação de entidades cartoriais, que fragmentam a classe trabalhadora e anulam a organização de setores da classe, amortecidos pela existência de uma entidade que lhes monopoliza a representação mas não lhes representa. Representa tão somente interesses financeiros escusos.

As negociações coletivas simbolizam a união dos trabalhadores que, individualmente, não conseguem se contrapor ao poder patronal. O Direito do Trabalho consagra a ideia de que "a união faz a força", de que somente coletivamente organizados os empregados conseguem obter a criação de direitos coletivamente negociados com as empresas. O hipossuficiente econômico deixa de sê-lo quando unido. Fragmentado, sua condição de parte mais fraca da relação mantem-se.

A situação econômica do Brasil de pleno emprego, formalização crescente dos empregados e aquecimento econômico sugerem um ambiente favorável às negociações coletivas. Porém, a Constituição Federal trouxe a democracia pluralista em diversos níveis, mas manteve pilares da estrutura corporativista que atentam contra a liberdade sindical e travam a construção de uma cultura jurídica trabalhista lastreada na autocomposição entre as partes e na possibilidade dos sindicatos criarem normas em comum acordo com as empresas.

O grande problema da Constituição atual é que tentou combinar avanços tímidos e pontuais no sentido da liberdade com manutenções estruturais corporativistas. Não há mediação possível entre ditadura e democracia; ou a Constituição assegura uma ou mantem a outra.

A CLT e a Constituição Federal foram forjadas em momentos históricos distintos com propósitos distintos. A CLT surgiu em um período de industrialização de um país rural com um governo ditatorial urbanista que sucedeu governos oligárquicos ruralistas. $\mathrm{O}$ governo Vargas acelerou a transformação da economia do país e o fez com mão de ferro, 
impondo normas e impedindo qualquer manifestação mais turbulenta ou conflituosa como é característico de governos autoritários. Nas relações industriais de trabalho, interviu nos sindicatos estatizando-os e mantendo-os sob controle ao passo que concedeu direitos individuais a serem tutelados pelo Estado. A Constituição expressa o fim de uma ditadura sangrenta e feroz que manchou a história brasileira por mais de vinte anos. Seu espírito era de liberdade, democracia, pluralidade e vitalidade da sociedade civil. Nas relações de trabalho, contudo, não garantiu a liberdade sindical, mantendo o padrão celetista de regulação centralmente estatal, dificultando (mas não impedindo) a autocomposição dos conflitos entre capital e trabalho típico de sociedades democráticas e plurais.

A combinação de liberalismo e autoritarismo não pode dar em bom resultado. $\mathrm{O}$ desenvolvimento sócio-econômico experimentado no século $\mathrm{XX}$ favoreceu $\mathrm{o}$ fortalecimento dos sindicatos, mas a estrutura legal do Direito Coletivo do Trabalho continua sendo um entrave ao pleno fortalecimento. A classe trabalhadora brasileira atual assemelha-se a um atleta olímpico correndo com bolas de ferro acorrentadas a seus pés.

Embora haja análises discordantes, o entendimento dominante no direito e demais ciências do trabalho é que a CLT surgiu para dominar os sindicatos em troca de direitos individuais. O primeiro objetivo foi alcançado, mas o segundo sempre foi apenas uma promessa.

A historiografia mostra que, quando Getúlio iniciou o processo de regulamentação legal da legislação social, o patronato não se opunha porque simplesmente não acreditava na aplicação das leis. Seja pela negativa dos empresários em observar os preceitos legais e por seu poder de barganha perante o Estado, seja pela incapacidade estrutural dos órgãos de fiscalização em acompanhar toda a produção econômica e garantir a aplicação celetista.

John French (2001, p. 37/38) mostra, por exemplo, que Segadas Vianna, Ministro do Trabalho de Vargas e membro da comissão que redigiu a CLT, estimava que $80 \%$ desta lei não era cumprida e atribuía sua existência à demagogia corporativista. Mesmo João Goulart, quando assumira o ministério em 1953, assumia a inobservância generalizada da lei.

Os defensores das negociações coletivas enquanto centro prioritário da produção de normas trabalhistas sempre alegam que são as partes que conhecem os problemas e podem solucioná-los da melhor forma. O Estado não tem como impor uma norma geral aplicável às diversas relações de trabalho e uma lei que o intentasse seria simplesmente inútil. French (2001, p. 26/27), comparando a regulação trabalhista americana com a brasileira e 
comparando a lei e a realidade, afirma ser melhor uma lei hipotética que promete $20 \%$ de melhoria e satisfaz $80 \%$ disso do que a CLT, que promete $80 \%$ e só entrega $20 \%$.

A artificialidade da CLT é constatada desde o seu nascedouro. O Departamento Nacional do Trabalho, órgão responsável pela fiscalização do cumprimento da legislação social, contava com 100 funcionários para todo o país em 1933 (SOUZA, 2008, p. 181). Somente em São Paulo, havia cerca de 3.400 indústrias e 120.000 operários em 1930 (SIMÃO, 1981, p. 41), o que denota a impossibilidade de o governo garantir a aplicação celetista. Em 1965, o Serviço de Higiene e Segurança do Trabalho de São Paulo possuía três médicos e um engenheiro para (não) realizar 8.000 perícias requisitadas (FRENCH, 2001, p. 19).

Mesmo atualmente, com a Justiça do Trabalho melhor estruturada e com décadas de vida ativa, mais de 2 milhões de reclamações trabalhistas são ajuizadas anualmente e é impossível que essa justiça especializada consiga resolver todos os casos a contento. Uma ação pode durar anos e os reclamantes são quase que obrigados a fazer um acordo, pressionados pela morosidade do judiciário, pelas frequentes campanhas de conciliação e pelos advogados que precisam receber seus honorários.

Suponha-se que uma empresa descumpre normas legais de um empregado referente a férias e horas extras por exemplo. Suponha-se que, se fossem tais direitos pagos regularmente, teriam um valor de $\mathrm{R} \$ 10.000,00$ sonegados pelo empregador. Se o empregado ingressa com uma reclamação e faz um acordo de $\mathrm{R} \$ 5.000,00$, isso significa que o judiciário garantiu meia CLT ao trabalhador, um atestado pleno e incontestável de inviabilidade do sistema celetista de repressão aos direitos coletivos e legalização de direitos individuais. Fora o fato de mais de um terço dos empregados sequer ter sua carteira de trabalho assinada, o que indica que boa parte das empresas ignora solenemente a CLT.

O historiador Samuel Fernando de Souza (2008) relata um interessante conflito de sindicatos baianos com a inspetoria local do Ministério do Trabalho em 1934, que culminara com a destituição do inspetor. Um enviado do ministério foi enviado para solucionar o conflito e encontrou 843 processos locais atrasados com toda sorte de denúncia. Os parques industriais de Valença e Maragogipe, dois dos três maiores do estado, não eram fiscalizados e não havia cumprimento sequer da jornada de 8 horas; os ferroviários reclamavam o cumprimento de férias; os panificadores trabalhavam 16 horas por dia sem descanso dominical. A inspetoria intervia nos sindicatos e muitos sindicalistas 
eram presos ou demitidos. A Federação Regional dos Trabalhadores Baianos agregava 47 sindicatos e foi declarada ilegal pelo inspetor que viria ser destituído.

A irônica descrição de Getúlio Vargas como "pai dos pobres e mãe dos ricos" encontra respaldo na constatação do historiador brasilianista John French:

\begin{abstract}
Os industriais paulistas, que entenderam como jogar o jogo, não tinham necessidade, após 1930, de se opor frontalmente à ideia da legislação em si, desde que eles pudessem estar certos do cumprimento das cláusulas antioperárias e da possibilidade de evitar, adiar ou minimizar suas disposições "prótrabalhador" por meio de uma interpretação "apropriada" e do não-cumprimento pelo governo e pelos tribunais (FRENCH, 2001, p. 43).
\end{abstract}

À ineficiência das instituições em garantir os direitos individuais somava-se a corrupção de servidores públicos e às relações promíscuas entre burguesia e Estado. A CLT despertou (e desperta) esperanças e expectativas aos trabalhadores, expectativa essa que transformava-se (e transforma-se) em frustração e descrença em seu cumprimento. Mas o legado repressor dos direitos coletivos foi mantido. "Durante o final dos anos 40, o governo evitou a demagogia trabalhista e compartilhou abertamente a convicção dos empregadores de que o aparato institucional trabalhista era útil somente para controlar a classe trabalhadora", afirma French (2001, p. 41).

Essa constatação anota o período constitucional após o Estado Novo e permite observar que a carapaça corporativa varguista surgiu em um período autoritário, mantevese em um breve período democrático liberal, acentuou-se em um novo período ditatorial e sobreviveu mais uma vez a outra constituição democrática. Ou seja, na democracia ou na ditadura, as relações de trabalho brasileiras são marcadas pelo aprisionamento dos sindicatos em uma estrutura pré-definida por lei engendrada há 80 anos, quando o Brasil sequer havia ganho uma Copa do Mundo!

A ordem democrático-constitucional atual é, inegavelmente, a mais avançada já experimentada pelo país. Sem dúvida, a vedação constitucional da intervenção do Estado nos sindicatos é um avanço que enterra diversos artigos celetistas relativos à organização e gestão dos sindicatos. Até a década de 80, o governo intervia nas entidades, destituía lideranças, nomeava interventores pelegos e atribuía para si o poder de outorgar a representação sindical mediante a famosa e extinta Carta Sindical. Em suma, os sindicatos 
brasileiros ainda eram estatizados há poucos anos. Isso sem falar nos mortos e desaparecidos.

Porém, a intervenção estatal direta nos sindicatos não era a única via e permanece intocada a intervenção no modelo de sindicato monopolista (via unicidade) e de financiamento compulsório (via imposto), ambos mecanismos heteronomamente definidos.

A definição de categoria profissional enquanto delimitador do controle e da referência formal das entidades sindicais está na contramão dos países de capitalismo central e das reivindicações dos trabalhadores. Delimitando o sindicato pelo setor econômico do seu empregador, restringe-se a sua atuação e fragmenta-se um conflito que deveria ser unificado. E essa fragmentação não é ocasional, é premeditada e visa o enfraquecimento da organização coletiva.

O regramento legal da organização sindical brasileira inicia-se na década de 1930 com Vargas. Antes desse enquadramento, os sindicatos se organizavam espontaneamente e tinham funcionamento instável. A partir da análise das organizações de trabalhadores em São Paulo, Azis Simão (1981) sugere uma classificação dos sindicatos de período pré-1930 que os definiriam em sindicato profissionalmente indiferenciado, profissionalmente diferenciado e profissionalmente articulado.

Os sindicatos profissionalmente indiferenciados reuniam indistintamente indivíduos relacionados ou não pelo seu oficio. Alguns chegaram a se reunir por etnia, mormente italianos e alemães, mas os mais importantes eram agrupados pela área de residência dos operários, motivo pelo qual é chamado também de sindicato de localidade. Há notícias de até 22 entidades dessa modalidade no interior, uma União de Ofícios Vários na capital e 10 outros menores organizados em torno de seus bairros. Foram extintos por força de lei na década de 1930.

Os sindicatos profissionalmente diferenciados ou de ofícios eram os mais comuns e agrupavam operários pela ocupação dos indivíduos, baseado no quadro das artes e ofícios da época. Gráficos, chapeleiros, sapateiros, pedreiros, metalúrgicos, mecânicos, alfaiates são exemplos. Podiam ser subdivididos pelas especializações destas atividades, coexistindo na capital, por exemplo, mais de uma agremiação correspondente a especializações da confecção de vestuários ou metalúrgicos. Organizavam-se por cidades ou até mesmo por bairros.

Os sindicatos profissionalmente articulados ou de indústria reunia operários de diferentes atividades como os profissionalmente indiferenciados, mas não tão 
indistintamente. Havia algum grau de articulação das atividades da empresa ou setor econômico. Os ferroviários, por exemplo, constituíam associações que agrupavam o pessoal do tráfego, das oficinas, da conservação e de cargas.

A organização interna das entidades era mais simples, normalmente com uma assembleia geral, uma comissão administrativa e um conselho fiscal ao lado de serviços de propaganda, biblioteca e escolas quando possível. Não havia atividades remuneradas mesmo entre ocupantes de cargos nem quadro de funcionários permanente, não apenas pela falta de recursos, mas também por questões ideológicas preocupadas em combater a burocratização. Se o acúmulo de tarefas demandasse a profissionalização de um quadro, este deveria receber um salário normal da profissão e não poderia votar ou ser votado. Havia representação sindical nos locais de trabalho, fato relevante por ser uma extensão do sindicato nas empresas.

As associações de grau superior também não obedeciam a um padrão homogêneo. Havia organizações que agrupavam categorias específicas como a União dos Trabalhadores Gráficos, organizações que agrupavam trabalhadores por setor econômico como a União Geral dos Ferroviários ou ainda associações que agrupavam quaisquer tipos de sindicatos como a Federação Operária de São Paulo. Podiam se organizar por município, por estado e havia também entidades nacionais.

Essas organizações autônomas chegaram a conviver com as entidades oficiais durante os anos 1930, mas foram completamente extintas pela força da lei. Os decretos definiram uma estrutura uniforme e reduzida das associações e vedou a existência de sindicatos à margem da oficialidade.

Importante notar que as antigas formas diversificadas de associações originaram diversificados modelos de luta coletiva, mormente greves. Entre 1915 e 1929, ocorreram em São Paulo 15 greves em seção de estabelecimento, 64 greves de estabelecimento, 28 greves de setor econômico, 5 greves interprofissionais, 3 greves generalizadas e 1 greve regional. Entre 1930 e 1940, só se observam greves em seção de estabelecimento, em estabelecimento e de setor econômico, extinguindo-se as greves interprofissionais e generalizadas, o que indica por qual motivo o governo segmentou os sindicatos por categorias.

Além de uniformizar o modelo sindical por categoria, único e verticalmente associado a federações e confederações, as alterações legais varguistas deram-lhes serviços assistenciais e uma burocracia permanente. Os sindicatos passaram a ofertar cooperativas 
de consumo ou crédito, assistência jurídica e médica dentre outras, assumindo funções que antes cabiam às cooperativas e às entidades de auxílio mútuo. Com o imposto sindical, surgiu a fonte de sustentação financeira permanente das entidades sindicais necessária à oferta dos novos serviços, contratação de empregados e remuneração de dirigentes eletivos que, a partir de então, puderam se afastar do trabalho para dedicar-se às tarefas sindicais.

A estrutura federal e confederal visava fragmentar a classe trabalhadora. Os sindicatos só tinham a possibilidade de associarem-se em nível estadual pela sua federação e em nível nacional pela confederação, todas independentes entre si. Não se admitia outras formas, nem mesmo as atuais centrais sindicais, para afirmar a segmentação das categorias e negar a divisão da sociedade em classe trabalhadora oposta à classe proprietária.

A CLT incorporou transformações impostas por lei que tornaram os sindicatos mais complexos, burocratizados e de unidade, heteronomia e centralização organizatórias, operando na forma uma transformação maior de conteúdo: "a passagem do sindicato marginal ao Estado para o sindicato integrado na própria instituição do Estado" (SIMÃO, 1981, p. 187).

A manutenção de elementos basilares corporativistas na atual Constituição impede que se afirme existir liberdade sindical no Brasil.

\footnotetext{
Em 5 de outubro de 1988, foi promulgada a Constituição em vigor que, ao tratar da organização sindical, sinalizou para a liberdade sindical, mas conservou - o que tem sido mantido até os nossos dias - ranços corporativistas, como a obrigatoriedade do sindicato único e a contribuição sindical obrigatória, mandamentos impeditivos da verdadeira liberdade sindical e, por consequência, da ratificação pelo Brasil da Convenção $n^{\circ} 87$ da OIT (TEIXEIRA, 2001, p. 57).
}

A plena liberdade sindical é pressuposto para o fortalecimento das contratações coletivas de trabalho, conforme atesta Otávio Pinto e Silva (2008, p. 77) ao afirmar que "não há como fortalecer o poder de negociações coletivas das entidades sindicais sem que se democratize a própria estrutura sindical brasileira”. Como poderão os sindicatos produzir livremente normas jurídicas coletivas se não lhes é devido sequer decidir como se organizar?

Há alguns elementos a caracterizar a liberdade sindical plena engendrada pela evolução histórica do Direito Coletivo do Trabalho. Liberdade de associação, de organização, de gestão e de ação compõem esse quadro de liberdades. 
A liberdade de associação é a primeira das liberdades. Os indivíduos devem possuir o direito de se associar livremente em defesa de seus interesses e criar suas entidades associativas. Os trabalhadores, então, podem livremente criar sindicatos sem ingerências externas e por sua própria vontade. Cada trabalhador individualmente deve ter o direito de se filiar ou desfiliar do sindicato sem ser coagido a isso por quem quer que seja. Mesmo os sindicatos devem desfrutar da liberdade de se associar a uma federação, confederação, central sindical ou a alguma entidade internacional.

A liberdade de organização decorre da anterior e, por esta, os trabalhadores podem definir autonomamente qual a melhor forma de associar-se, se em torno de um sindicato, de uma cooperativa, de uma entidade de auxílio mútuo, de uma central etc. Ao criar um sindicato, podem escolher se este representará uma categoria, um ofício ou trabalhadores de um ramo econômico ou o que quer que seja. A criação de um sindicato deve ser reconhecida legalmente por mero registro, sem pré-requisitos impostos.

A liberdade de gestão diz respeito a democracia interna dos sindicatos. Estes devem decidir seus próprios estatutos com os respectivos mecanismos de eleição de dirigentes, o direito de oposição, a disputa de ideias, os instrumentos de sustentação financeira, a administração destes recursos e das atividades da entidade. O Estado não pode impor nada de forma a não deliberar previamente pelos trabalhadores livres.

A liberdade de ação é a consagração final do sistema de liberdades sindicais. É aqui que se realiza a autonomia privada coletiva e o a função de existir dos sindicatos. $\mathrm{O}$ direito de representar seus filiados perante órgãos públicos, de proporcionar-lhes assistência jurídica, médica, ou econômica, de elaborar uma formação sindical adequada e, função das funções, de negociar coletivamente com as empresas as condições de trabalho, criar normas jurídicas trabalhistas e equilibrar as relações pela força associativa, garantindo a dignidade dos trabalhadores pela negociação em si e pelas normas aprovadas. A liberdade de ação política também deve ser ressaltada. O ex-presidente, de seu sindicato e da República, Lula sempre justificava a criação do Partido dos Trabalhadores pela constatação da existência de empresários que enveredavam pela política. "Se tem patrão no Congresso, tem que ter trabalhador também". É natural ao movimento sindical construir partidos políticos e eleger representantes, mormente entre as categorias mais fortes. $\mathrm{Na}$ atual legislatura, há entre 60 e 70 deputados federais oriundos de sindicatos.

A liberdade sindical plena está consagrada pela Convenção $n^{\circ} 87$ da OIT. Tramita no Congresso Nacional desde a década de 1940 e sua incompatibilidade formal com a 
Constituição Federal é mais uma prova de que a Magna Carta trouxe uma democratização geral da sociedade brasileira mas negou-se a democratizar as relações de trabalho.

Todos os elementos caracterizadores da liberdade sindical plena - as liberdades de associação individual e coletiva, de organização, gestão e ação - estão previstas na Convenção $\mathrm{n}^{\circ} 87$ da OIT. Seu regime de liberdade sindical plena é avançado e incompatível com os resquícios corporativistas presentes na Constituição Federal de 1988. Para que o Brasil ratifique essa norma internacional, terá que promover a alteração do art. $8^{\circ}$ da CF de modo a evitar o conflito formal e material entre as normas.

A ratificação da Convenção no 87 da OIT e a consagração da liberdade sindical no Brasil dependem da supressão de algumas normas constitucionais. A unicidade sindical prevista no art. $8^{\circ}$, II terá que ser abolida. Conforme dispõe o art. $2^{\circ}$ da Convenção 87 , cabe aos próprios trabalhadores organizar seus sindicatos como acharem conveniente. O Estado e a lei devem abster-se de impor condições prévias a essa organização.

Pelo mesmo fundamento, a obrigatoriedade da associação por categoria profissional ou diferenciada deveria ser revogada na Constituição e no art. 511 da CLT. Os trabalhadores até poderiam optar por essa força de sindicalização, mas a preferência do movimento sindical é pela associação por ramo de produção e, independente da escolha, caberia aos próprios trabalhadores definir o melhor.

A mesma contradição entre o art. $2^{\circ}$ da Convenção 87 e o art. $8^{\circ}$, II da Constituição fundamentaria a revogação da delimitação territorial mínima de um município. A base territorial também deve ser definida pelo melhor interesse dos trabalhadores. Não que se defenda a fragmentação sindical, mas em uma cidade como São Paulo, por exemplo, poderia haver sindicatos definidos por regiões. A base territorial mínima, como já se observou, é o outro lado da moeda da unicidade e ambos devem ser revogados.

A extinção do imposto sindical, mantido pelo art. $8^{\circ}$, IV da CF, também deveria necessariamente ser revogado. Os trabalhadores devem livremente escolher a melhor forma de sustentação financeira e os que não optassem pela sindicalização não podem ser obrigados a pagar por uma associação a qual não se filiem. Fora o fato de ser um absurdo uma associação privada de empregados ter sua sustentação imposta pelo Estado e recolhida pelo empregador!

Em termos de liberdade sindical em acordo à Convenção 87 da OIT, a Constituição brasileira apresentou alguns avanços como a vedação ao Poder Público de interferir na organização sindical e de exigir sua autorização para fundar sindicatos (art. 8 , I), a 
liberdade de filiação (art. $8^{\circ}, \mathrm{V}$ ), o direito de contratar coletivamente condições de trabalho (art. $7^{\circ}, \mathrm{XXVI),} \mathrm{a} \mathrm{participação} \mathrm{dos} \mathrm{sindicatos} \mathrm{nas} \mathrm{negociações} \mathrm{coletivas} \mathrm{(art.} 8^{\circ}, \mathrm{VI}$ ) e em órgãos públicos colegiados (art. 10 ${ }^{\circ}$ ). Esses avanços devem ser celebrados ao mesmo tempo em que denunciada seja a sua insuficiência.

Ao lado da ratificação da Convenção $n^{\circ} 87$ da OIT, a legislação brasileira deveria avançar na regularização da organização por local de trabalho (muito além do art. $7^{\circ}, \mathrm{XI}$ e art. 11 da $\mathrm{CF}$ ) e na proibição, punição e reparação de práticas anti-sindicais, compreendidas essas como todas as ações que prejudiquem o trabalhador ou o sindicato no exercício das atividades sindicais coletivas.

O movimento sindical sempre lutou pela sua liberdade plena e pelo direito de negociar coletivamente condições de trabalho mais favoráveis. A doutrina trabalhista costuma afirmar que os sindicatos percorrem historicamente três fases: proibição, autorização regulada e liberdade. A proibição ocorre porque o patronato e o Estado atuam repressivamente contra a organização coletiva dos trabalhadores. A autorização regulada já apresenta um quadro geral de lutas que tornam inviável a mera proibição, mas o movimento não se contenta e persegue seu objetivo final que é a liberdade. Por essa análise, pode-se observar que os empregadores sempre tentam impedir os empregados de se organizar e lutar por seus direitos. Cada benefício conquistado em prol dos empregados é uma vitória arrancada dos empregadores e o Direito do Trabalho é exatamente isso, uma conquista de direitos. A liberdade sindical e o direito a celebrar acordos coletivos representam o direito de conquistar direitos.

Aos primeiros decretos varguistas do início da década de 1930 que iniciaram a regulamentação corporativista dos sindicatos, estes responderam com greves e muitos sindicatos continuaram organizados à margem do sistema oficial. Contudo, a força da lei prevaleceu contra as entidades não oficiais e, de certa forma, muitas categorias viram-se forçadas a aderir à regulamentação legal.

O movimento sindical renascido durante a industrialização do milagre econômico na ditadura militar de 1964 retomou vigorosamente a bandeira da liberdade e da contratação. Os metalúrgicos do $\mathrm{ABC}$, segmento vigoroso do proletariado industrial responsável pelo sindicato mais forte do país desde então, colocaram a liberdade plena na ordem do dia. 
No I Congresso dos metalúrgicos de São Bernardo, realizado em 1974, foram aprovadas resoluções que expressavam a plataforma da própria diretoria: a revogação da política salarial e a negociação direta com os patrões, contratos coletivos de trabalho, plena liberdade sindical (SADER, 2010, p. 180/181).

As famosas greves do ABC do final da década de 1970 foram provocadas, em grande parte, pelo direito às negociações coletivas. O sindicato dos metalúrgicos propunha aos empresários, todos os anos, uma pauta de negociação visando celebrar uma convenção coletiva para a categoria. Vigia à época uma lei que reajustava os salários em índices que variavam com a inflação. Os empresários recusavam-se a negociar, instaurava-se um dissídio coletivo e a Justiça do Trabalho concedia o reajuste previsto pela lei. Todos os anos o fato se repetia e a insatisfação dos trabalhadores com as empresas e a justiça crescia.

Quando a imprensa noticiou que o índice divulgado pelo governo relativo ao ano de 1973 fora manipulado, a insatisfação transformou-se em ação. Foi o estopim que desencadeou um movimento grevista espontâneo que se espalhou fábrica por fábrica. No ABC, o sindicato catalisou a revolta generalizada e conduziu a greve; em São Paulo, o sindicato era presidido por um notório pelego e o movimento grevista organizou-se em torno de comissões autônomas por fora da entidade.

Em plena ditadura militar, na vigência da Lei de Segurança Nacional e proibição do direito de greve, o movimento paredista assumiu não só a pauta por melhores condições de trabalho, mas também reivindicou o direito de greve e de negociação coletiva de trabalho. A defesa da liberdade sindical era uma luta contra o empresariado, o Estado e a lei. É famosa a frase do então dirigente sindical Lula a afirmar que "a CLT é o AI-5 dos trabalhadores".

O chamado sindicalismo autêntico nascia com a marca da defesa da liberdade sindical plena, com o fim das amarras do que entendiam como tripé autoritário: o Poder Normativo da Justiça do Trabalho, a unicidade e o imposto sindical. Reivindicavam a contratação coletiva direta com o patronato sem interferência do Poder Judiciário.

Iram Jácome Rodrigues (2001) enuncia algumas características do sindicalismo vinculado à CUT, central sindical engendrada pelo sindicalismo autêntico e sua expressão geral, no que tange a concepção de organização sindical. A resistência à estrutura corporativa e a defesa da organização no local de trabalho destacam-se. 
Há uma compreensão enraizada fortemente contrária à imposição legal da estrutura sindical que ainda perdura. O sindicalismo vinculado à CUT enxerga essa estrutura como uma camisa de força que amarra os sindicatos ao Ministério do Trabalho e à Justiça do Trabalho, impõe uma conciliação artificial entre empregados e empregadores e fragmenta a luta, haja vista a dificuldade de organização de mobilizações unificadas entre categorias diferentes. Defende a organização sindical por ramo de produção em vez de por categoria, o fim do imposto sindical, financiamento livremente estabelecido pelos trabalhadores desvinculado do Estado e o pluralismo sindical não pela existência de vários sindicatos na mesma base, mas pela construção da unidade fruto da vontade autônoma obreira. O direito de greve é defendido amplamente sem qualquer objeção legal. Para o sindicalismo cutista, a greve em serviços essenciais deveria ser auto regulamentada pelos próprios trabalhadores, que possuiriam discernimento e maturidade suficientes para que não dependam da existência de uma Lei de Greve que deixa o movimento paredista à mercê do Poder Judiciário.

Registre-se que no ano de 2012, a CUT patrocinou um plebiscito nacional sobre o imposto sindical, organizando-o enquanto uma campanha contra o imposto. Em resposta, as outras cinco centrais sindicais reconhecidas no país organizaram uma campanha a favor, o que demonstra que há uma clara cisão no movimento sindical brasileiro entre os setores que defendem a liberdade sindical e os setores que se beneficiam da estrutura atual e querem a sua manutenção.

Há uma compreensão negativa sobre o papel desempenhado pela Justiça e pelos advogados do trabalho. A Justiça por atuar indevidamente na contenção dos conflitos coletivos. Defendem a supressão do Poder Normativo e da intervenção em movimentos grevistas e a redução de sua atuação. Os advogados por colocarem seus interesses econômicos acima dos interesses dos trabalhadores. Rodrigues constata uma crítica até mesmo aos advogados dos próprios sindicatos.

As negociações coletivas são associadas ao fortalecimento do poder dos trabalhadores. A CUT acredita que a negociação direta baseia-se na legitimidade do sindicato perante seus filiados e na sua força. Nas palavras de um dirigente sindical cutista, "sem negociação direta não há como fortalecer a liberdade e autonomia sindical, e o real poder dos trabalhadores" porque o conflito coletivo fundamenta-se no poder real, na “correlação de forças real que existe numa dada conjuntura, entre interesses antagônicos, interesses diversos" (apud RODRIGUES, 2011, p. 104). 
Para que as negociações coletivas sejam fortalecidas, o entendimento dessa corrente do sindicalismo brasileiro é pela necessidade da organização por local de trabalho. $\mathrm{O}$ sindicato atual é considerado "de porta de fábrica", não está dentro do local de trabalho e isso impõe sérias limitações. As chamadas comissões de fábrica estão no cotidiano da empresa, acompanhando as necessidades diárias dos empregados e fiscalizando o cumprimento das convenções coletivas e mesmo da lei. Portanto, reivindicam a organização no local do trabalho de forma autônoma, desvinculada do sindicato e complementar a este. As comissões de fábrica seriam necessárias, então, para fortalecer a contratação coletiva de trabalho e para superar o sindicalismo fora das empresas, que não precisa de legitimidade porque sustentado por um imposto.

Justamente com o intuito de fortalecer a contratação coletiva e a implementação da organização no local de trabalho, os sindicatos de metalúrgicos do $\mathrm{ABC}$, de Taubaté, Sorocaba e de Salto apresentaram um projeto de lei instituindo o Acordo Coletivo de Trabalho com Propósito Específico (ACE). O projeto foi apresentado à sociedade em 2011, por ocasião da comemoração dos trinta anos da primeira comissão de fábrica do Brasil, implantado na fábrica da Ford em São Bernardo do Campo.

Segundo a cartilha disponível na internet ${ }^{2}$, a ideia do projeto é estimular o país a adotar a "negociação coletiva como instrumento mais moderno para a solução dos conflitos pertinentes às relações de trabalho e à representação sindical no interior da fábrica, como condição fundamental à democratização das relações entre trabalhadores e empresas". Visaria a proposta garantir segurança jurídica ao convencionado coletivamente e sua eficácia pela fiscalização no local de trabalho.

Para celebração desta modalidade, os sindicatos deveriam possuir comissões de fábrica previstas em estatuto e instaladas de fato, habilitação no Ministério do Trabalho e Emprego e mais da metade da categoria filiada ao sindicato. Pelo lado das empresas, deveriam reconhecer as comissões de fábrica e não ter qualquer condenação por práticas anti-sindicais. Essa modalidade de contratação especial seria um acordo coletivo celebrado por empresa e teria que ser aprovado por votação secreta e por mais de $60 \%$ dos votos dos empregados. Seu objetivo é estipular condições de trabalho específicas a uma determinada empresa e observaria tão somente os direitos previstos no art. $7^{\circ}$ da Constituição. Na prática, o que os metalúrgicos propõem é trocar a representação no local de trabalho pela CLT, considerada antiquada e ultrapassada.

\footnotetext{
${ }^{2}$ Disponível em www.smabc.org.br. Acesso em 25/05/2012.
} 
A categoria metalúrgica é uma das mais fortes do Brasil e as experiências dos metalúrgicos do $\mathrm{ABC}$ estão entre as mais avançadas tanto no que diz respeito a contratação coletiva quanto a comissões de fábrica. Os metalúrgicos defendem a Convenção no 87 da OIT e pretendem, com esse projeto, dar um passo a mais em direção à superação das amarras corporativistas e à plena liberdade sindical. Por estarem na vanguarda do movimento sindical, podem generalizar suas experiências para outras categorias e consolidar um movimento sindical enraizado, autônomo, representativo e suficientemente forte para negociar livremente as condições de trabalho de seus filiados.

A democratização das relações de trabalho pelo fortalecimento das negociações coletivas e organização no local de trabalho é um imperativo de uma sociedade democrática que valoriza a dignidade da pessoa humana. A contratação coletiva não só assegura a dignidade como é, por si própria, expressão da dignidade humana associada ao trabalho assalariado. "A liberdade sindical é um dos direitos fundamentais do homem, integrante dos direitos sociais, componente essencial das sociedades democráticopluralistas" (SIQUEIRA Neto, 2001, p. 85).

As normas internacionais relativas a direitos humanos e relações de trabalho apontam nesse sentido. Associadas ao direito comparado dos países de capitalismo central, mormente os europeus, percebe-se o déficit democrático que o Brasil ainda vive nessa área e a urgência em se ratificar a Convenção $n^{\circ} 87$ da OIT, superando décadas de atraso e autoritarismo.

José Francisco Siqueira Neto demonstra a necessidade de se instrumentalizar o contrapoder dos trabalhadores com o escopo de obter o equilíbrio nas relações entre capital e trabalho. O poder dos empregadores se impõe sobre os empregados e corrigir essa distorção depende do fortalecimento do poder dos empregados de forma a obter a administração democrática do conflito pelo diálogo e busca do consenso, não olvidando a possibilidade de um eventual impasse ser resolvido pelo exercício do direito de greve.

Para que isso seja possível, há que se estabelecer bases legais que minimizem a discrepância entre os poderes dos empregadores e empregados através da plena liberdade sindical e organização por local de trabalho e, a seguir, assegurar o espaço social do diálogo e confronto entre as partes, mormente as negociações coletivas. Estes objetivos não serão possíveis nem em uma estrutura corporativista, que reprime o conflito e avoca para o Estado a sua (artificial) resolução, nem em uma estrutura liberal clássica como a 
americana, que não assegura o equilíbrio entre os poderes e permite que o poder patronal prevaleça pela força bruta.

A liberdade sindical e a organização por local de trabalho são direitos humanos fundamentais na medida em que corrigem o desequilíbrio e estabelecem o espaço de negociação e confronto das partes, ajustando autonomamente as condições de trabalho. Essa liberdade associativa plena e sua consequente ação coletiva transformam-se, então, "no centro de gravidade mais evoluído do direito do trabalho, funcionando como ponto de partida da negociação coletiva em seu sentido mais moderno e, por conseguinte, de todo o sistema de relações de trabalho" (SIQUEIRA Neto, 2001, p. 82).

Por essa perspectiva, um Direito do Trabalho verdadeiramente democrático tem nas negociações coletivas e na liberdade sindical o seu centro irradiador normativo e, a partir daí, atuam a legislação social, o Poder Judiciário, o Poder Executivo e demais mecanismos privados de composição de conflito.

No Brasil, vige justamente o contrário. O Direito do Trabalho parte inicialmente da atuação jurisdicional individual minuciosa e artificialmente definida por lei para, secundariamente, os sindicatos amarrados por uma legislação corporativa e antidemocrática negociarem de forma fragmentada, com a possibilidade do exercício do Poder Normativo em substituição à contratação coletiva. Ou seja, ao invés de priorizar a composição livre pelas partes, essas são acorrentadas de forma a o Estado solucionar os conflitos pela sua negação. A atuação sindical mais forte, no Brasil, é sempre contrária ao Direito do Trabalho, como o demonstram as sucessivas intervenções dos Tribunais Regionais do Trabalho ao estipular índices de reajustes, decretar ilegalidades de greves, estabelecer percentuais absurdos de funcionamento de serviços durante movimentos paredistas e determinar o retorno imediato ao trabalho de forma absolutamente autoritária e, pode-se afirmar, inconstitucional.

O sistema brasileiro, conclui-se,

não é democrático, não serve para realizar a negociação coletiva de trabalho, dificulta a participação dos trabalhadores e o diálogo social, não ajuda a composição voluntária dos conflitos e estimula - fundamentalmente pela ausência do contrapoder do empregador - o crescimento geométrico dos processos trabalhistas de natureza individual (que é também um indicador do descumprimento das leis do trabalho no país) (SIQUEIRA Neto, 2001, p. 83). 
A atuação do principal sindicato do país, nas lutas promovidas ao fim do milagre econômico, nas câmaras setoriais ou na proposta atual de acordo coletivo com propósito específico demonstra os caminhos reivindicados pelos trabalhadores. O que estes pretendem é um sindicato legítimo, organizado nos locais de trabalho, negociando pela força coletiva as condições de trabalho de seus associados e participando altivamente das decisões que lhes digam respeito. Em suma, reivindicam a autonomia coletiva que lhes confere a dignidade preceituada constitucionalmente.

A interpretação do conceito de dignidade da pessoa humana aplicado ao empregado subordinado sugere que somente pela via da livre organização dos trabalhadores e das negociações coletivas com a consequente convenção ou acordo coletivo será possível alcançar essa dignidade, elevada a norma fundamental constitucional.

Viu-se que a definição de dignidade da pessoa humana trabalhada pelo Direito Constitucional é baseado no pensamento de Kant. Afirma que o ser humano não possui um valor mensurável porque possui dignidade, racionalidade, capacidade de agir em acordo com sua vontade engendrada pela razão. O ser humano é digno porque pode decidir livremente o seu destino, as suas ações, a busca dos seus objetivos e ninguém poderá ser submetido por outrem, coisificado, visando atingir os objetivos estabelecidos por este outrem. Essa dignidade surge como um direito humano de primeira geração, burguês, individualista. Como se aplicaria essa definição de dignidade ao empregado subordinado, submetido ao poder diretivo do empregador? A resposta a essa pergunta só pode ser encontrada na autonomia privada coletiva. $O$ roteiro que segue baseia-se na obra de Ronaldo Lima dos Santos (2009).

A etimologia da palavra autonomia indica a capacidade do sujeito reger-se por leis próprias, escolher as leis que regerão sua própria conduta. Contrapõe-se à heteronomia, que seria a condição do sujeito que tem suas ações regidas por leis que lhe são estranhas, oriundas de outrem. Autonomia, então, seria a capacidade do sujeito determinar suas ações, seus comportamentos, os fins que pretenda perseguir e os caminhos a serem seguidos. Insere-se nos princípios da dignidade e da liberdade humana.

A vontade é o ato psíquico, a representação mental de uma ação motivada pela razão, pelo desejo. É a faculdade de querer, de realizar algo, de agir, o fundamento da ação. A vontade é a condição que permite ao sujeito fazer ou não fazer algo como bem lhe aprouver. No Direito, a vontade é fundamental para formar um ato jurídico, sua expressão cria, modifica ou extingue relações jurídicas. 
A autonomia da vontade desempenhará papel central no Direito construído após a Revolução Francesa. O livre-arbítrio e o determinismo são as duas correntes opostas que explicam a autonomia da vontade. Pelo primeiro, é o indivíduo que escolhe uma decisão final entre mais de uma possibilidade; pelo segundo, fatores externos ao sujeito definem a vontade humana. A evolução das teorias acerca da autonomia da vontade indica que o conteúdo desta autonomia é impulsionado pelo arbítrio racional do sujeito, mas este sujeito não está isolado do mundo e haveria uma série de contingências e limitações a condicionar a autonomia (que não é absoluta) da vontade.

Pela existência desses condicionantes externos é que pode-se falar em acordo de vontades. Sujeitos distintos com vontades distintas poderiam acordar seus desígnios de modo a haver um ajuste de vontades. Unidas, as vontades perderiam o que lhes diferenciavam ao mesmo tempo em que conservam suas identidades. Esse é a fundamente do contrato. O contrato origina-se de dois arbítrios que são unificados e afirmados pelas partes, tornando o seu objeto algo exterior e particular submetido às vontades.

A autonomia da vontade é um elemento da liberdade em geral e é também uma "liberdade jurídica, isto é, o poder insuprimível do homem de criar por um ato de vontade uma situação jurídica" (SANTOS, 2009, p. 110). Pelo ajuste entre autonomias das vontades das partes, estas podem contratar, criar uma situação jurídica que lhes traga direitos e obrigações. A autonomia da vontade seria a prerrogativa das relações jurídicas contratuais, pressuposto da capacidade jurídica. Por isso, a vontade não pode ser viciada, enganada, coagida para que não se invalidade o negócio. O contrato é a expressão da vontade e tem validade a menos que se prove que é fruto de uma vontade maculada, não livre.

No Direito, a autonomia era associada, inicialmente, a entes públicos que detinham o poder de elaborar leis próprias. Posteriormente, passou a significar uma realidade regida por leis próprias, por ela criada, que convive com outras normatividades. A autonomia, agora, tornou-se uma autonomia privada.

A autonomia privada define a regulamentação que os sujeitos dão a si próprios, independente dos poderes públicos. Somente possível em sociedades de pluralismo jurídico, a autonomia privada baseia-se da concepção de que o Estado não pode resolver todos os problemas dos indivíduos e a estes é reconhecida uma esfera de iniciativa jurídica que lhes permite satisfazer suas necessidades. Uma lei é uma regra jurídica aplicada aos 
particulares mas não elaborada por estes; um contrato é também uma regra jurídica, mas elaborada por quem o executa.

A ideia de autonomia privada superou a ideia de autonomia da vontade enquanto fundamento do negócio jurídico. A autonomia da vontade é uma definição subjetiva, psíquica, focada na criação e manifestação da vontade para a realização de um ato jurídico; a autonomia privada vai além e traz um significado mais objetivo, concreto, expressa o poder dos particulares de criar normas jurídicas. De certa forma, por tratar-se de uma superação ao invés de uma negação, é o link entre o subjetivo e o objetivo, porque este prescinde daquele.

Pela autonomia privada, os particulares podem autorregular seus interesses em acordo a suas vontades e de outrem. É o poder concreto de estabelecer normas jurídicas. Não apenas ativa um direito que lhe é inerente (anterior), mas também cria direitos, normas (posteriores). Trata-se de um poder que possui concretude porque refere-se a interesses específicos, enquanto a lei é abstrata, geral. A autonomia privada vincula as partes contratantes e é limitada pelo ordenamento jurídico, como se vê nos institutos engendrados de Direito Civil do pacta sunt servanda, dos vícios de consentimento e do caráter supletivo das leis.

Por ser um instituto criado durante as revoluções burguesas sob influência do iluminismo e da revolução industrial, a autonomia privada é inicialmente concebida como uma autonomia individual. Individual porque limitada à atuação dos titulares dos poderes definidos e delimitados que estabelecem entre si relações jurídicas intersubjetivas de indivíduo para indivíduo. Os efeitos normativos dirigem-se aos sujeitos concretamente determinados que celebram o negócio, porque cada um dispõe da liberdade para atuar em acordo aos seus desígnios e cabe a ele arcar com as consequências.

A autonomia privada é o poder de criar tais normas e sua expressão e manifestação concreta é o negócio jurídico. Este é o ato pelo qual o sujeito regula seus interesses em relações com outrem, criando normas que atraem o poder coercitivo do Direito. A autonomia privada, então, é o poder de celebrar negócios jurídicos visando realizar seus objetivos e interesses, criando os particulares detentores do poder norma que vincula as partes. O contrato é o negócio jurídico por excelência.

O contrato é a consagração jurídica da vitória da burguesia revolucionária contra as instituições feudais em derrocada. Na Idade Média, vigia o poder dos reis e dos papas, que impunham suas vontades e submetiam toda a sociedade europeia. O surgimento da 
burguesia comerciante demandou a superação da antiga estrutura por uma "livre", onde todos pudessem expressar suas vontades e definir seu futuro autonomamente. A sociedade de trocas surgida com o capitalismo determinava que todos os indivíduos fossem um feixe de direitos e deveres com poder de contratar livremente e toda a produção não estatal de normas expressava-se em um contrato: a compra e venda, o aluguel, o casamento, a doação, tudo era contratado. Inclusive o trabalho.

A revolução industrial generalizou as fábricas e consagrou a indústria enquanto célula de produção capitalista clássica. Os milhares de trabalhadores que aglomeravam-se nas fábricas vinculavam-se aos empregadores por um contrato, exclusivamente individual como vigia à época. A associação de trabalhadores era considerada um atentado ao contratualismo e foi duramente reprimida à força. A burguesia já tinha deixado o posto de classe dominada e tornara-se classe dominante.

A luta coletiva dos trabalhadores impôs o reconhecimento do associativismo sindical. Um trabalhador individualmente considerado comparecia ao mercado de trabalho em condição deveras desfavorável para contratar com o empresariado. Coletivamente, a contratação se daria em condições infinitamente melhores porque o poder contratual estaria sobre uma base coletiva muito mais forte.

A autonomia privada coletiva nasce justamente dos sindicatos em negociação direta com as empresas por contratos de emprego mais favoráveis, com salários mais altos, jornadas menores, proteção à mulher e ao menor e todos os elementos que constam do nascedouro do Direito do Trabalho. Primeiro, este ramo do direito surgia das reivindicações dos trabalhadores mas emanava do Estado, que decretava leis que garantissem a proteção do hipossuficiente, amenizando as condições dos contratos individuais de emprego. Depois, os próprios trabalhadores representados pelo sindicato puderam contratar coletivamente diretamente com as empresas, reduzindo a intervenção legal em prol da autocomposição das partes.

A autonomia privada coletiva nasce com o reconhecimento da existência da vontade comum ao grupo que conforma o interesse coletivo. A doutrina afirma que esse interesse coletivo não se confunde com a soma dos interesses individuais. Data vênia, não parece ser essa a melhor interpretação.

A filosofia dialética diz que o geral está contido no particular e o particular está contido no geral. Os trabalhadores tiveram que se associar porque o interesse de cada um é o mesmo interesse de todos e o interesse de todos é o interesse de cada um. O sindicalismo 
nasce a partir da percepção de que os problemas que afligem cada empregado é comum a todos e só é possível resolvê-lo em uma luta unificada porque todos almejam seguir a mesma direção. A ideologia liberal afirma que o mundo é a soma dos indivíduos, mas a divisão da sociedade em classes sociais é a realidade que se impõe. Há contradição entre os indivíduos, mas há também contradição entre as classes. No caso da classe trabalhadora, resolver seus problemas coletivamente não foi uma opção, foi uma necessidade que se impôs perante o fato de que a contratação individual manteria todos na mais absoluta miséria e somente a contratação coletiva poderia superar essa condição.

Expressando opinião dominante, Amauri Mascaro Nascimento (2009, p. 1342) diferencia os contratos individuais de emprego das convenções coletivas pelo fato de estas serem fruto de partes contraentes elaborando normas de condutas aplicáveis a terceiros enquanto que naquele as partes agem em nome próprio na constituição de direitos e deveres. Contudo, admite que as convenções só se realizam pelos contratos individuais e prevalecem sobre estes. Se uma categoria celebra um acordo coletivo estabelecendo um salário de $\mathrm{R} \$ 1.000,00$, isso significa que cada empregado individualmente receberá $\mathrm{R} \$$ $1.000,00$ por mês e que $\mathrm{R} \$ 1.000,00$ é o salário conquistado pela categoria. Os interesses dos empregados e sua consequente dignidade sempre serão oriundos da tensão entre o indivíduo e o coletivo.

Porém, em uma sociedade fragmentada em classes, a dignidade do empregado será necessariamente uma realização coletiva. Se a dignidade da pessoa humana representa a possibilidade do sujeito determinar suas ações e sua vida e a autonomia é a capacidade do sujeito determinar suas próprias leis, é na autonomia privada coletiva que os trabalhadores realizam sua dignidade na sociedade capitalista. É na convenção coletiva ou no acordo coletivo de trabalho que o sujeito coletivo trabalhador ajusta suas vontades, seus interesses, em situação de igualdade com os empregadores e consegue fazer valer seus interesses.

Em prefácio de obra clássica sobre os trabalhadores que viriam a criar o chamado sindicalismo autêntico, Marilena Chaúi identifica aquele revigorado movimento proletário enquanto um sujeito novo por três motivos: por terem criado seus próprios movimentos sem teorias prévias que os designassem, por não terem um centro prévio a quem servissem de engrenagem (os sindicatos ainda eram estatais, estavam sobre intervenção, não podiam celebrar convenções coletivas nem fazer greve) e por tratar-se de um sujeito coletivo, social, desprovido de individualidade egoísta e onde os indivíduos se reconheciam 
mutuamente, decidiam e agiam em conjunto em função da busca de uma cidadania comum. Essas classes trabalhadoras organizadas

\begin{abstract}
passaram a fazer parte da cena histórica, não como atores desempenhando papéis pré-fixados, mas como sujeitos criando a própria cena através de sua própria ação e, com isso, "constituíram um espaço público além do sistema da representação política" permitida, ou seja, o espaço da participação cívica e trabalhista (apud SADER, 2010, p. 15).
\end{abstract}

Uma legislação individual artificialmente imposta e uma estrutura sindical corporativa, ambas representadas pela CLT, são "papéis pré-fixados"; a liberdade sindical plena e o direito de negociar coletivamente condições de trabalho da categoria são "sujeitos criando sua própria cena através de sua própria ação".

No mesmo sentido, José Geraldo de Souza Júnior, analisando como o Direito absorve esse novo sujeito coletivo de direito originário das lutas sindicais do $\mathrm{ABC}$, afirma que o instigante desses estudos surgidos no fim dos anos 1970

Foi a percepção de que este processo instaurava práticas políticas novas, em condições de abrir espaços sociais inéditos, revelando novos atores capazes de se auto-organizarem e de se auto-determinarem, à margem ou até mesmo em contraposição aos espaços constituídos para a sua expressão tradicional (SOUZA Júnior, 1999, p. 255).

Capacidade de auto-organização e autodeterminação são justamente as expressões maiores da dignidade da pessoa humana vinculadas aos trabalhadores. E isso ocorreu contra o Direito posto naquele momento de profunda e autoritária intervenção estatal nas relações coletivas de trabalho. Não há autonomia possível com tamanha intervenção e repressão.

O contrato individual foi a consagração pelo direito privado da garantia da dignidade da pessoa humana associado este princípio fundamental jurídico à burguesia em luta contra a aristocracia feudal. O contrato coletivo foi a consagração pelo direto social da garantia da dignidade da pessoa humana associado este princípio fundamental jurídico ao trabalhador em luta contra a burguesia. Deve-se resgatar aqui que os direitos de primeira geração, dentre os quais o contrato se insere, foram conquistas da classe burguesa 
ascendente em sua luta emancipatória contra a antiga ordem feudal monista e os direitos de segunda geração são conquistas do proletariado frente à burguesia opressora após assumir a condição de classe dominante.

Por tudo, uma interpretação da dignidade da pessoa humana associada à figura do empregado conclui que a melhor interpretação do Direito Constitucional em geral e do Direito Constitucional do Trabalho em particular é aquela que baseia-se na autonomia privada coletiva e afirma o direito de negociar coletivamente e de celebrar convenções ou acordos coletivos de trabalho associada aos demais direitos individuais elencados no art. $7^{\circ}$ na condição de conquistas anteriores e consagradas, também oriundas de reivindicações coletivas da classe trabalhadora. Essa é a tensão entre o coletivo e o individual que deve reger a dignidade do trabalhador: o direito de conquistar direitos associado aos direitos já conquistados.

É de se lamentar que a Constituição Federal de 1988 não tenha garantido essa dignidade em sua plenitude porque não permitiu a plena liberdade sindical ao manter as estruturas corporativas ("papéis pré-fixados") da categoria econômica, unicidade monopólica, base territorial municipal mínima, federações e confederações piramidais e imposto sindical. Não há autonomia nem liberdade onde não há auto-organização. Mas não se pode olvidar que a atual situação econômica favorável abre amplas possibilidades para as negociações coletivas e os bancários podem se beneficiar disso...

\subsection{A Organização Sindical Bancária e a Superação do Assédio Moral}

A categoria bancária localiza-se em um setor da economia que sempre foi importante para o desenvolvimento do capitalismo e adquiriu centralidade nas últimas décadas. Em virtude dessa centralidade, a organização sindical dos bancários sempre teve perspectivas contraditórias: se, de um lado, enfrenta um dos mais poderosos e influentes conglomerados capitalistas, de outro os bancários constituem uma categoria mais avançada do que a média, sendo uma das vanguardas do movimento sindical geral.

Os tópicos que seguem buscam analisar como os bancários organizam seus sindicatos e se relacionam com o Direito do Trabalho a partir de convenções e acordos 
coletivos de trabalho e como essa organização sindical pode ser a melhor forma de resolver o problema do assédio moral organizacional nos bancos.

\subsubsection{A organização sindical bancária}

A criação de sindicatos de bancários no Brasil remonta à década de 1920, quando foi criado o Sindicato dos Bancários de São Paulo, mas foi na década de 1930 que consolidou-se a organização da categoria em nível nacional. É nesse período, já sob o Governo Vargas, que surgem sindicatos de bancários no Rio de Janeiro, na Bahia e por todo o país.

Por ser uma categoria que atua em um setor econômico avançado, concentrado e internacionalizado, seus membros estão integrados em um locus desenvolvido do capitalismo, que lhe demanda uma escolaridade alta e habilidades organizacionais e relacionais. Por isso, o movimento sindical bancário é forte e atuante desde os primórdios, organizando greves, negociações coletivas e articulando a categoria nacionalmente.

Por se confrontar com um poderosíssimo conglomerado econômico que sempre teve relações próximas ao Estado, os sindicatos de bancários sofreram intervenções diretas em diversos momentos, conforme informa Ericson Crivelli (2000). Quando Vargas, autorizado pelo Decreto-Lei $n^{\circ} 6$ de 1935, promoveu uma intervenção generalizada nos sindicatos do país, diversas entidades de bancárias sofreram intervenções que forçaram um recuo ou uma integração às políticas oficiais. Em 1947, o Governo Dutra, com o apoio do STF, colocou o PCB na ilegalidade. Como a liderança dos bancários era fortemente vinculada ao "partidão", nova onda de intervenções na categoria foi desfechada e somente em 1951 o Sindicato de Bancários de São Paulo conseguira eleger uma diretoria desvinculada da intervenção federal. A ditadura de 1964 foi a que interviu mais radicalmente. Não só destituindo diretorias legitimamente eleitas e nomeando diretores pelegos, mas promovendo a concentração bancária a partir da Lei 4.595/64 ao passo que incentivava a fragmentação dos sindicatos da categoria, no pior estilo "dividir para conquistar". Até 1984, muitos sindicatos de bancários tiveram suas lideranças cassada pelo regime por conta da tentativa de promoção da greve no ano anterior. Essas intervenções 
sempre ocorriam em um momento onde a categoria tinha acumulado forças e sempre originou um refluxo no movimento com o enfraquecimento e esvaziamento dos sindicatos.

Uma característica marcante da organização sindical dos bancários é que esta sempre se notabilizou pela nacionalização de suas lutas. Em 1992, os bancários celebraram a primeira convenção coletiva nacional da história e isso só foi possível após décadas de lutas e, não coincidentemente, no período mais democrático da história brasileira. Dos anos 1930 em diante, em quase todas as décadas houve greves nacionais de bancários. Os dados que seguem foram obtidos pela obra de Crivelli (2000).

Em 1934, a greve nacional culminou com a aprovação do Decreto n ${ }^{\circ} 54$ que criou o Instituto de Aposentadorias e Pensões dos Bancários (IAPB) e garantiu estabilidade à categoria após dois anos de trabalho na mesma empresa. Este movimento paredista foi capitaneado pelos sindicatos de São Paulo, Rio de Janeiro e Santos e foi sucedido por intenso período de repressão através da Lei de Segurança Nacional do Estado Novo.

Em 1945, nova greve nacional da categoria seria esvaziada pela saída do sindicato de São Paulo após julgamento favorável do dissídio coletivo pelo TRT. Outra greve nacional ocorreria em 1946 encerrada com acordo. Novamente, o período de mobilizações seria sucedido por um período de duras repressões, agora pelo governo de Dutra fortemente orientado pelos EUA no período da Guerra Fria.

A década de 1950 seria fundamental para a organização nacional dos bancários. Em 1951, a greve nacional seria desmobilizada pelos bancos e pelo Estado. Os bancos celebraram rapidamente acordos coletivos separados com os maiores sindicatos, fragmentando o movimento, ou levaram os conflitos para o TRT, o que contava com repúdio dos sindicatos por significar indevida intervenção judicial nas greves. O governo estabeleceria ali uma tática pró-empregadores que utilizaria até os anos 80.

\footnotetext{
Os banqueiros receberam recursos financeiros das autoridades monetárias no curso da paralisação através das operações de redesconto, o que, associado ao fato de os bancos continuarem com suas chefias realizando várias operações de depósito e empréstimos, possibilitou considerável redução do prejuízo potencial do movimento grevista (CRIVELLI, 2000, p. 124).
}

Essa passagem dá a dimensão do quadro de restrição à liberdade sindical no Brasil que, infelizmente, ainda não foi superada. Os bancos recusavam-se a negociar nacionalmente como era a vontade dos sindicatos. Durante as greves, ajuizava dissídios 
coletivos visando encerrar o movimento ao passo que recebia recursos do governo para manter-se durante o período paredista. Ou seja, quando os sindicatos conseguem mobilizar-se a despeito das amarras corporativas, os empregadores contam com a ajuda do Estado para esvaziar e reprimir o movimento.

O IV Congresso Nacional dos Bancários de 1952 criou uma Comissão Sindical Permanente para coordenar os bancários em nível nacional. O VI Congresso em 1956 criou a Comissão Executiva Nacional dos Bancários para consolidar a nacionalização. O VII Congresso em 1957 extinguiu a executiva e criou oficialmente a Confederação dos Trabalhadores em Empresas de Crédito (CONTEC), consagrando a unificação do movimento sindical bancário para o enfrentamento com os bancos que, em resposta, viriam a criar o Congresso de Bancos nos anos 1960.

A década de 1960 iniciou-se com um turbulento período de mobilizações sociais e com a posse de João Goulart, ex-ministro do trabalho de Vargas. Os sindicatos de bancários envolviam-se nas mobilizações gerais e organizaram nada menos do que três greves nacionais da categoria antes do golpe, em 1961, 1962 e 1963. Com o golpe de 1964 e a ditadura a serviço do grande capital travestida de militar, instaurou-se um momento de repressão generalizada na sociedade e os bancários, na condição de uma das categorias mais fortes e organizadas dentre os trabalhadores, sofreram pesada intervenção.

Além de nomear dirigentes sindicais dóceis ao regime e ao patronato nas entidades, os militares forçaram a fragmentação da categoria pelo desmembramento dos sindicatos e os acordos coletivos foram todos segmentados, anulando em um curto período o acúmulo de uma década de lutas. "A atomização político-sindical que emergiu das intervenções interrompeu o lento processo de construção dos mecanismos de solução dos conflitos coletivos através da negociação coletiva direta que os sindicatos vinham tentando", afirma Ericson Crivelli (2000, p. 126). Os anos que seguiram foram de intensa repressão sindical e achatamento salarial que garantiram o "Milagre Econômico", o que prova que a ditadura só era militar na forma, porque o conteúdo era claramente empresarial. Nessa fase, os reajustes eram definidos por lei, esvaziando o papel reivindicativo e negociador dos sindicatos, e criou-se o FGTS para acabar com a estabilidade decenal, o que burocratizou ainda mais as entidades sindicais pelo medo dos dirigentes serem dispensados após o exercício do mandato.

No final dos anos 1970, o surgimento do sindicalismo autêntico contaminou a categoria bancária. Surgiram importantes oposições bancárias que pleiteavam “o 
afastamento dos sindicatos do Estado, as negociações diretas, a contratação coletiva com os banqueiros e representação nos locais de trabalho" (CRIVELLI, 2000, p. 71), antenadas os metalúrgicos do $\mathrm{ABC}$ em sua luta, acima de tudo, pela liberdade sindical. $\mathrm{O}$ sindicalismo autêntico venceu as eleições dos sindicatos dos bancários de Porto Alegre em 1975 e São Paulo em 1979 e retomou a combatividade e a organização nacionalizada da categoria.

Os bancários tentaram uma greve em 1979 sem sucesso e outra em 1983 que for reprimida e os sindicato sofreram a última intervenção direta do Estado, retomando as atividades em 1985. Nesse período, os bancos já estavam organizados em torno da Federação Nacional dos Bancos (FENABAN), o sindicato patronal, mas se negavam a negociar nacionalmente, pois isso fortaleceria os trabalhadores bancários.

Ericson Crivelli (2000, p. 131 e ss.) sugere uma hipótese que distingue a unificação dos bancários no período pré-1964 do período pós-1979. No primeiro, à atuação sindical somava-se o concurso do Estado. O nacional desenvolvimentismo e o PCB criam que o Estado tinha um papel importante e prioritário a desempenhar. As lideranças acreditavam que o governo poderia ajudar o movimento como na criação do IAPB e na garantia de leis de proteção. A contratação coletiva não era prioridade. Já na segunda fase analisada, à ação sindical seria somada o fator econômico. Ao fim da ditadura, os bancos já estavam deveras concentrados, tendo sobrado poucas instituições grandes e nacionalizadas organizadas pela FENABAN. A data-base de todos os sindicatos de bancários unificou-se em $1^{\mathrm{o}}$ de setembro e a unificação salarial, de certa forma, uniformizaria a concorrência interbancária. Crivelii não fala aqui, mas o sindicalismo autêntico trazia consigo um forte sentimento antiestatal, que se traduzia na defesa da liberdade sindical plena, com contratação coletiva direta e organização por local de trabalho, consentâneo com a norma mais importante da OIT, a Convenção ${ }^{\circ} 87$.

O fim da ditadura militar permitiu que o movimento sindical bancário seguisse o seu curso sem mais intervenções a partir de 1985. Com isso, o movimento encontrou as condições necessárias para unificar-se nacionalmente, objetivo perseguido desde a década 1930. Os sindicatos de bancários voltaram a reivindicar e mobilizar nacionalmente, tendo realizado greves nacionais durante quase todos os anos e reivindicando a celebração de convenção coletiva de trabalho nacional para a categoria, o que foi conseguido em 1992, com a convenção assinada por 120 sindicatos, sete federações e pela Confederação Nacional dos Bancários (CNB), entidade criada por sindicatos cutistas naquele ano. Em 
2006, a CNB foi substituída pela Confederação Nacional dos Trabalhadores do Ramo Financeiro (CONTRAF) com o intuito de organizar nacionalmente os trabalhadores do ramo financeiro. A CONTRAF representa bancários, financiários, promotores de venda, securitários, especialistas em tecnologia da informação, empregados da bolsa de valores dentre outros.

Durante os anos 1980, os sindicatos dos bancários conseguiam organizar grandes movimentos, com assembleias cheias e representativas, greves sólidas, passeatas de impacto dentre outras manifestações. Quando inicia-se a década de 1990 com a hegemonia neoliberal no país, a classe trabalhadora sofre brutais ataques com desemprego e precarização das condições de trabalho. E os bancários não ficaram impunes.

O neoliberalismo consagra o capital financeiro como centro da economia global. Como quase todas as ações econômicas envolvem bancos, os bancários sofreram as consequências. Houve greves nacionais de bancários em 1990 e 1991 que conseguiram repor a inflação, mas, nestes dois anos, nada menos que 132 mil bancários foram dispensados; em 1994, esse número chegaria a 200 mil (JINKINGS, 2002, p. 310/313).

A partir da implantação do Plano Real em 1994 e da posse de FHC em 1995, o neoliberalismo consolidou-se e a categoria bancária foi uma das mais atingidas. Basta dizer que havia cerca de 800 mil empregados em bancos em 1990 e esse número despencou para 370 mil em 2002. Ou seja, mais da metade dos trabalhadores foram dispensados em pouco mais de uma década! O sistema financeiro era responsável por mais de $20 \%$ das dispensas durante o Plano Real e os bancos estatais federais, que não assinavam a convenção coletiva nacional da categoria, sofria severo desmonte; entre 1994 e 1997, por exemplo, quase 40 mil empregados do Banco do Brasil foram desligados.

As dificuldades de mobilização cresciam. As greves encontravam dificuldades em obter adesão maciça da categoria e tornaram-se mais localizadas. Em muitos anos, a categoria não conseguia sequer repor a inflação e os bancos passaram a conceder reajustes em PLR e bônus. Se na década de 80 havia grandes mobilizações e conquistas para a categoria, nos anos 90 as lutas passaram a ser de resistência contra perda de direitos e desvalorização salarial. Nesse período houve também conquistas como a cesta-alimentação e a própria PLR, mas o panorama geral foi de aumento de desemprego anualmente, concentração e fortalecimento dos bancos e precarização dos contratos de emprego.

Muitos bancos estatais foram privatizados e, dentre os federais, vigia a prática de "reajuste zero" imposto pelo governo e programas de demissão voluntária. Segundo o 
Sindicato dos Bancários do ABC (2012, p. 10), entre 1995 e 2002, para uma inflação de 104,69\%, os empregados do Banco do Brasil tiveram reajustes salariais de 36,15\% e os da CEF, 28,26\%, em uma acintosa desvalorização de rendimentos.

As reformas da gestão dos recursos humanos nos bancos, já analisada, impactaram a organização sindical bancária. A obra de Nise Jinkings (2002) trás alguns depoimentos de lideranças sindicais da categoria que permitem visualizar os principais problemas.

O primeiro, sem dúvida, é a terceirização. O deslocamento do contrato de emprego para um empregador terceiro retirou da base dos sindicatos de bancários um vasto contingente de empregados. A CONTRAF afirma que há cerca de 250 mil terceirizados tradicionais e a FEBRABAN afirma haver 170 mil correspondentes bancários, totalizando mais de 420 mil. Considerando haver pouco mais de 500 mil bancários atualmente, significa dizer que quase metade dos trabalhadores que enriquecem o sistema financeiro não pertence à base dos sindicatos de bancários. A convenção coletiva nacional bancária trás uma série de direitos e benefícios que não atingem esses terceirizados, mormente a PLR, que é uma participação nos lucros que eles geram mas não obtém retorno.

Em um banco, pode haver diversos sindicatos que alcançam os empregados da segurança, limpeza, telemarketing, correspondentes etc. Isso fragmenta e enfraquece a luta dos trabalhadores e reduz-lhes as possibilidades nas negociações coletivas. Se os sindicatos fossem organizados por ramo ao invés de categoria, todos esses empregados poderiam estar unificados sob o mesmo sindicato. Mas a legislação corporativa que ainda vige no país, impede essa unidade. Basta uma assembleia e tem-se um novo sindicato com financiamento garantido compulsoriamente e monopólio da representação para celebrar acordo coletivo ou ajuizar reclamações. Esses terceirizados e correspondentes não podem filiar-se aos sindicatos de bancários por conta do monopólio da categoria imposto pela unicidade que, paradoxalmente, pulveriza a representação.

A expansão das agências é outro elemento abordado. Antigamente, centenas de bancários aglomeravam-se em poucas agências, permitindo o maior convívio, interação, discussão de problemas, o que facilitava a identidade da categoria e a penetração do sindicato. Hoje, a proliferação de pequenas agências com reduzido número de empregados dificulta essa interação. Até para o sindicato mobilizar os empregados para uma greve ou distribuir um jornal é mais difícil porque há inúmeras agências com poucas pessoas trabalhando. 
Um terceiro elemento apontado é o crescimento proporcional dos gerentes de venda, assessores e outros profissionais que percebem comissões, premiações e outras modalidades variáveis de remuneração. Muitas vezes, esses profissionais conseguem um aumento em uma conversa com o seu superior e é-lhes mais fácil valorizar o seu salário individual do que coletivamente.

Diversos outros elementos são apontados por Jinkings. As privatizações que reduziram o contingente de bancários com estabilidade e que se mobilizava mais facilmente; a concentração geográfica no Sudeste do país da maior parte das agências e empregos; a intensa competição interna que transforma um colega em um adversário; o medo do desemprego em um setor econômico de altíssima rotatividade. Um aspecto não assinalado pela autora é o impacto da informatização nas greves. Se os clientes podem realizar quase todas as operações pela internet ou em caixas eletrônicos, os bancos não perdem dinheiro quando há uma paralisação de empregados. Todos esses aspectos devem ser analisados pela categoria com vistas à sua superação.

Os elementos supra citados surgem no bojo das transformações trazidas na década de 1990. Essas características do trabalho bancário consolidaram-se a mantem-se na atualidade. Contudo, pela força da categoria e pela alteração do quadro econômico, atualmente muito mais favorável ao trabalho, o movimento sindical bancário fortaleceu-se na última década e a convenção coletiva nacional tem assegurado muitos ganhos, tornando-a um dos principais instrumentos normativos coletivamente negociados no país.

A recente geração de empregos em todas as áreas econômicas fez o nível de desemprego despencar a patamares em torno de 5\%, reduzindo o exército de reserva que enfraquecia os sindicatos e aumentando o poder de barganha destes. $\mathrm{O}$ emprego nos bancos acompanhou a tendência e saltou dos 370 mil em 2002 para mais de 500 mil em 2011. Não retornou aos patamares da década de 1980, mas mantem-se em um crescendo que renova e fortalece a categoria.

Todos os índices apresentados nas convenções coletivas recentes refletem a força da categoria e o bom momento vivido para as negociações coletivas. Entre 2004 e 2011, somam-se oito anos seguidos com reajustes salariais trazendo ganhos reais acima da inflação, sendo que, nesse período, os bancos federais passaram a assinar as convenções coletivas junto com os demais bancos privados. Nesse octênio, para uma inflação de 52\%, o piso salarial da categoria teve um acréscimo de $99,29 \%$ e o reajuste médio foi de $72,4 \%$ 
(SINDICATO DOS BANCÁRIOS DO ABC, 2012, p. 10), valorizando consideravelmente a remuneração geral.

Em 1995, os bancários tornaram-se a primeira categoria de trabalhadores brasileiros a celebrar uma convenção coletiva prevendo pagamento de PLR, no valor de uma parcela proporcional de $72 \%$ do salário do empregado acrescido de uma parcela fixa de $\mathrm{R} \$ 200,00$. No ano seguinte, a parcela proporcional caiu para $60 \%$ e a fixa subiu para $\mathrm{R} \$ 270,00$. Em 1997, a parcela proporcional variou para 80\% do salário, índice que se manteve até 2007. Em 2008, aumentou para 90\%. No ano de 2011, a parcela fixa foi de R\$ 1.400 contra R\$ 1.100,80 de 2010. Em 1997, a PLR passou a ser balizada pelo lucro líquido do banco, sendo, no mínimo, 5\% deste líquido e, no máximo, 15/\%. Em 2006, surgiu uma parcela adicional linear a ser paga.

A regra básica da PLR bancária em 2011 é a seguinte: uma parcela proporcional de $90 \%$ do salário e uma fixa de $\mathrm{R} \$ 1.400,00$ com o teto individual de $\mathrm{R} \$ 7.827,29$. Caso essa distribuição não atinja 5\% do lucro líquido do banco, majora-se o pagamento até que atinja os 5\% ou que o valor individual da PLR atinja 2,2 salários do empregado. Em caso de majoração, o teto passa a ser de R \$ 17.220,04. Além disso, há uma parcela adicional de 2\% do lucro líquido do banco linearmente distribuída, com limite individual de $\mathrm{R} \$ 2.800,00$.

As entidades sindicais da categoria demonstram pleno conhecimento de que a PLR e demais remunerações variáveis inserem-se em um contexto de flexibilização em que o risco do negócio é deslocado cada vez mais para os empregados, contrariando o que preceitua a CLT - se um banco tem lucro zero ou prejuízo, por exemplo, desobriga-se de pagar a PLR. O fato de não ter natureza salarial também deporia contra essa forma de remuneração. Entretanto, a PLR permite que os empregados compreendam que é o seu trabalho que enriquece a empresa e que ele tem direito a perceber parte do lucro que criou, fortalecendo a luta coletiva.

Para o bem ou para o mal, as chamadas remunerações variáveis cresceram de importância na composição dos salários dos bancários, variando de 5,4\% do total em 1995 para 14,5\% em 2011. A atual reivindicação das centrais sindicais para que o governo isente as PLR de imposto de renda indica que os sindicatos absorveram o instituto. Registre-se que há alguns bancos que possuem acordo coletivo com regras próprias para distribuição de participação nos lucros; mas os principais bancos do país regem-se pela convenção coletiva. 
A convenção coletiva estabelece outros ganhos para os empregados. Há um auxíliorefeição (Cláusula 14 ${ }^{\mathrm{a}}$ ) pago no formato de tíquete utilizado para as despesas diárias com alimentação durante a jornada e um auxílio cesta-alimentação (Cláusula 15a) no formato de cartão magnético utilizado para compras realizadas em supermercados. O auxílio cestaalimentação, em 2002, valia $\mathrm{R} \$ 163,72$ praticamente o mesmo valor de uma cesta básica média em São Paulo, que era de R \$ 162,59. Em 2011, o auxílio variou para R \$339,08 para uma cesta básica de $\mathrm{R} \$ 267,08$ e paga-se uma $13^{\circ}$ parcela. O auxílio-refeição é de $\mathrm{R} \$$ 423,16 em 2011, cerca de $\mathrm{R} \$ 20,00$ por dia.

A convenção coletiva bancária 2011/2012 prevê ainda uma série de benefícios extralegais. O piso salarial para empregados com mais de três meses de banco (Cláusula $3^{\mathrm{a}}$ ) é de $\mathrm{R} \$ 976,00$ para pessoal de portaria, contínuos e serventes e $\mathrm{R} \$ 1.400,00$ para escriturários, caixas, tesoureiros e pessoal de tesouraria, sendo que estes três últimos percebem, no mínimo, R \$ 1.900,36 com as gratificações. Há um adicional por tempo de serviço (Cláusulas $6^{\mathrm{a}}$ e $7^{\mathrm{a}}$ ) e o adicional noturno é de $35 \%$ (Cláusula $9^{\mathrm{a}}$ ). A gratificação de função prevista no art. $224, \S 2^{\circ}$ da CLT é de $55 \%$ (Cláusula $11^{\mathrm{a}}$ ), a gratificação de caixa é de $\mathrm{R} \$ 339,72$ (Cláusula 12a) e a gratificação de compensador de cheque é de $\mathrm{R} \$ 110,70$ (Cláusula $13^{\mathrm{a}}$ ), sendo que este último percebe um auxílio para deslocamento noturno (Cláusula 20a) de $\mathrm{R} \$$ 68,22. Há um auxílio-creche/auxílio-babá (Cláusula 17 ) de $\mathrm{R} \$$ 284,85 mensais por filho até 71 meses de vida, um auxílio filhos excepcionais ou deficiente físico (Cláusula 18 ${ }^{\mathrm{a}}$ ) no mesmo valor mas sem limite de idade e um auxíliofuneral (Cláusula 19a) de $\mathrm{R} \$ 653,57$ para falecimento de cônjuge ou filhos menores. Estudantes tem faltas abonadas em dias de vestibular ou de prova obrigatória (Cláusula $22^{\mathrm{a}}$ ). A Cláusula $23^{\mathrm{a}}$ estabelece as ausências permitidas em caso de falecimento de familiares (4 dias), casamento (5 dias), pais de recém-nascidos (5 dias) dentre outros. A Cláusula $24^{\mathrm{a}}$ prevê licença-maternidade de 180 dias. A Cláusula $25^{\mathrm{a}}$ prevê algumas estabilidades como estabilidade pré-aposentadoria de 12 meses para empregados com 5 anos de vínculo empregatício no banco ou de 24 meses para empregados com 28 anos de banco se homem e 23 anos se mulher. Esta cláusula preceitua ainda estabilidade de dois meses para pais após o nascimento do filho ou para gestantes que abortaram. A Cláusula $27^{a}$ afirma que o banco empregador pagará a diferença entre eventual benefício previdenciário recebido pelo empregado e o salário deste enquanto durar o benefício. Todos os direitos convencionais que digam respeito a cônjuge dos empregados estende-se a relações homoafetivas (Cláusula $47^{\mathrm{a}}$ ). 
Estes são apenas alguns exemplos de direitos previstos na Convenção Coletiva. Há dezenas de outros relativos a segurança, direitos sindicais, saúde dos empregados, requalificação profissional, CIPA e outros temas que totalizam mais de sessenta cláusulas. Há ainda acordos coletivos assinados com os principais bancos estabelecendo comissões de conciliação voluntária (CCV) para dirimir conflitos individuais quando um bancário desliga-se do emprego. O objetivo aqui não é analisar minuciosamente cada direito previsto pela convenção e pelos acordos; é apenas constatar a grandeza e variedade de direitos conquistados pela categoria ano a ano através de negociações coletivas.

A CCT dos bancários é um instrumento normativo elaborado autonomamente pelas partes, fruto dos embates, conflitos e consensos alcançados na mesa de negociações. A convenção expressa a correlação de forças na luta entre capital e trabalho, às vezes mais, às vezes menos favorável aos sindicatos. Sua análise permite constatar que, além de a categoria bancária ser forte e organizada, somente em um longo período democrático como o vivido atualmente pelo Brasil é possível que os sindicatos promovam suas ações coletivas com negociações e greves que resultam em novos direitos conquistados e consagrados sem retrocessos. São vinte anos de contratação coletiva nacional, fruto do acúmulo de pouco menos de trinta anos sem intervenção direta nos sindicatos dos bancários pelo governo.

A força da categoria bancária é facilmente constatável em sua atuação para além da CCT. Os sindicatos dos bancários sempre estão entre as categorias mais fortes e representativas na organização do movimento sindical geral e tem atuação marcante na construção da CUT e do PT por exemplo. Diversos quadros oriundos do sindicalismo autêntico dos bancários desempenharam importantes funções políticas. Dois governadores de estado, Olívio Dutra (RS) e Wellington Dias (PI) são egressos de sindicatos de bancários estaduais. Com a ascensão do PT à presidência em 2003, ao menos quatro bancários exerceram funções ministeriais: Olívio Dutra (Cidades), Paulo Bernardo (Planejamento e Comunicação), Ricardo Berzoini (Previdência e Trabalho) e Luiz Gushiken (Secretaria de Comunicação), além de diversos parlamentares.

A convenção coletiva dos bancários é um documento vivo em defesa da liberdade sindical e do direito de conquistar direitos. Sem olvidar dos resquícios corporativistas que permanecem no ordenamento jurídico brasileiro e da necessidade de sua superação, a democracia, a vedação da intervenção direta nos sindicatos e a contratação coletiva 
submetida ao jogo de forças das partes mostra-se o melhor caminho para regulamentar os conflitos entre o capital e o trabalho.

\subsubsection{A luta contra o assédio moral}

As transformações no mundo do trabalho em geral e no trabalho em bancos em particular ocorreram de forma muito rápida. O movimento sindical precisa de um tempo para absorver as transformações e agir adequadamente em relação às novidades. É lícito supor que a alteração da força de trabalho bancária, em qualidade e quantidade, reflete-se também na composição dos sindicatos e que os novos mecanismos de gestão de recursos humanos trazem novos problemas e desafios que refletem-se na ação sindical.

A nova organização do trabalho em bancos, que mobiliza subjetivamente o bancário vendedor e quantifica o trabalho através de metas, engendrou o assédio moral organizacional com reflexos imediatos nos empregados. Problemas relacionados à saúde mental se igualaram ou ultrapassaram os problemas relacionados à saúde física. Os sindicatos de bancários passaram a enfrentar esse problema novo e combatê-lo. $\mathrm{O}$ ano de 2006 demarca esse novo momento porque é quando as entidades sindicais acumularam informações sobre a problemática e passaram a atacá-la.

Em 2006, a CONTRAF e o Sindicato dos Bancários de Pernambuco realizaram uma pesquisa nacional que envolveu 2.609 bancários para verificar a ocorrência e frequência de atos negativos no ambiente de trabalho em banco, relacioná-los à saúde dos empregados e às características da organização do trabalho. A pesquisa foi já foi devidamente analisada nesta dissertação. Seus números, que apontaram que quase $40 \%$ da categoria sofre humilhações organizacionais e tem problemas generalizados de estresse, foram tão impactantes que os bancos concordaram em incluir na convenção coletiva daquele ano a previsão de criação de um grupo de trabalho com vistas a criar um programa de prevenção de conflitos. Nos diálogos travados com a FENABAN, a CONTRAF contava com especialistas das áreas de medicina, psicologia e direito cujas pesquisas com bancários indicavam, unanimemente, que a origem das patologias que acometiam os trabalhadores estavam ligadas a "la presión dela productividad, la excessiva carga de trabajo y la falta de reconocimiento por parte de las empresas". Outra conclusão inevitável a que chegaram 
é que o assédio e a violência no local de trabalho não era uma questão meramente individual, porque a própria organização do trabalho propiciava a propagação das práticas. Punir o agressor individualmente era, então, necessário mas insuficiente se não fosse encarado o problema em termos mais gerais.

A partir de então, o movimento sindical bancário passou a associar o assédio moral às metas abusivas cobradas pelos bancos e a combater os dois problemas de forma unitária. Essa associação é facilmente constatável pela leitura de diversos documentos elaborados pelas entidades da categoria. A Folha Bancária, jornal do Sindicato dos Bancários de São Paulo, Osasco e Região, em sua edição n” 61, fala que "a luta por um ambiente de trabalho saudável e pelo fim das metas abusivas e do assédio moral, principais causas de adoecimento na categoria bancária, estão entre as principais frentes de ação do sindicato". O informativo da Secretaria de Saúde e Condições de Trabalho do Sindicato dos Bancários do ABC afirma que "com o aumento dos casos de Assédio Moral e a Violência Organizacional (metas abusivas), já somos uma das categorias com mais afastamentos na questão da saúde mental". A Revista dos Bancários, editada pela CONTRAF, de agosto de 2008, afirma que o eixo central da campanha nacional da categoria naquele ano seria "o combate ao assédio moral e outras formas de violência organizacional e às metas abusivas".

A constatação de que o assédio moral nos bancos é mais uma questão organizacional do que interpessoal e que as metas são o maior problema para os bancários disseminou-se nas entidades sindicais. Nas campanhas nacionais dos últimos anos, por exemplo, o combate às metas abusivas tem sido um dos eixos centrais das reivindicações e a preocupação com a saúde física e mental dos bancários é latente. A Revista dos Bancários de agosto de 2008 informava que uma psiquiatra do Rio de Janeiro participara da $10^{\circ}$ Conferência Nacional dos Bancários e associara "doenças como LER/DORT e transtornos mentais às metas abusivas impostas pelas instituições financeiras, ressaltando que o esgotamento físico e emocional, fruto da sobrecarga de trabalho, baixa a auto-estima e causa adoecimento".

O Sindicato de São Paulo, Osasco e Região, cuja base concentra cerca de $25 \%$ de toda a categoria do país, criou a campanha “- Metas, + Saúde". A cartilha que divulga a campanha inicialmente afirma categoricamente que "o processo de organização do trabalho bancário leva a um elevado grau de adoecimento do trabalhador" e que o principal problema é a imposição unilateral pelos bancos de metas abusivas. Antes da campanha 
nacional da categoria em 2009, o sindicato submeteu uma ampla consulta em sua base para saber quais os principais pontos a serem abordados. A resposta foi contundente: $69 \%$ afirmaram que a prioridade deveriam ser as metas e $67 \%$ priorizaram o assédio moral. A cartilha incentiva que os empregados denunciem situações de assédio causadas pela pesada cobrança pelo cumprimento das metas e informa que a $11^{\text {a }}$ Conferência Nacional dos Bancários daquele ano incluiu na minuta de reivindicações a luta contra o assédio moral e as metas abusivas.

O Sindicato dos Bancários do $\mathrm{ABC}$ desenvolveu uma experiência pioneira em 2012, um projeto denominado "Acolhendo Desgaste Mental do Trabalho Bancário". O informativo da Secretaria da Saúde da entidade trás informações a respeito do programa. Primeiro, faz uma análise das transformações do trabalho na atualidade e seus impactos na categoria bancária, que inclui fatores de desgaste como adaptabilidade física e mental a uma tensão criada para aumentar o ritmo de trabalho, enxugamento de pessoal, desgaste dos que permanecem e desenvolvem a chamada "síndrome do sobrevivente", intensificação do labor e polivalência exigida aos empregados, pressão para o cumprimento das metas draconianamente impostas pelos bancos e cobrança de uma gestão de excelência. Tudo isso estaria transformando as LER/DORT em lesões secundárias entre os bancários, porque estes estão vivendo uma epidemia de doenças mentais como estresse, depressão, paranoia etc. Por isso, a entidade criou o projeto para organizar seis encontros de duas horas por semana reunindo bancários acometidos por problemas mentais. A escuta dos trabalhadores municia o sindicato com informações que o auxiliam a enfrentar o problema deles e prevenir os demais.

Nos termos desse trabalho, não é possível nem necessário analisar documentos produzidos por sindicatos de bancários do Brasil inteiro. Os documentos acima citados representam o pensamento médio da categoria. Porém, é preciso fazer referência a uma publicação da CONTRAF que talvez seja a que apresente mais profundamente o posicionamento das organizações sindicais a respeito do tema.

Trata-se dos Cadernos da CONTRAF nº 01, de agosto de 2010. Essa publicação insere-se na campanha - Metas, + Saúde, já devidamente incorporada e nacionalizada pelo movimento sindical bancário. Esse Caderno nº 01 intitula-se “Assédio Moral, Violência Organizacional e Metas Abusivas", o que define de plano a realidade do trabalho em bancos. A expressão "violência organizacional" foi cunhada pelos bancários no bojo da campanha - Metas, + Saúde e define o fenômeno do assédio moral organizacional de 
forma mais consistente do que a definição das ciências do trabalho incorporada pelo Direito.

A publicação lembra que conflitos no ambiente de trabalho podem ser saudáveis e possibilitam o desenvolvimento da criatividade e o surgimento de novas ideias quando baseado nas tarefas, na cooperação e na diversidade. Mas os conflitos tornam-se disfuncionais quando calcados em imposição e medo, constrangimento, ameaça e veda os questionamentos. "Os conflitos disfuncionais no ambiente de trabalho atingem a dignidade humana e podem acarretar prejuízos à saúde, à auto-segurança e ao desenvolvimento de pessoas e grupos, sejam estes envolvidos diretos ou indiretos”. O foca da publicação é o assédio moral organizacional, mas são citados também o assédio interpessoal, o assédio sexual, discriminações e outros comportamentos que englobam o que a OIT chama de violência no trabalho.

Este caderno da CONTRAF conceitua o assédio moral, descreve uma série de atos que podem configurá-lo e diferencia o assédio interpessoal do organizacional. Todos esses conceitos já foram abordados nesta dissertação, motivo pelo qual torna-se despiciendo tratá-los novamente. Mas é preciso ressaltar que os bancários compreendem a diferença entre o assédio que envolve uma pessoa ou um grupo específico de forma não generalizada e o assédio decorrente de "estratégias de gestão inadequadas, associada com abuso do poder diretivo do empregador", cujos exemplos são a gestão por injúria, gestão por estresse e gestão por medo.

A gestão por injúria caracteriza-se pela ofensa à dignidade, honra e imagem das pessoas, humilhações, constrangimentos e exposições depreciativas manifestadas na fala ou em atos. São exemplos citados rebaixamento de empregados que não atingem o desempenho imposto pelo empregador, e-mails coletivos que comparam o desempenho dos empregados e os expõe de forma constrangedora, uso de palavras ofensivas, ataques pessoais em público e premiações negativas. A gestão por estresse baseia-se em pressões exageradas sobre os trabalhadores e muitos destes acabam naturalizando a situação. Exemplos citados são as cobranças constantes, publicação de rankings de resultados, metas draconianas, prazos curtos para as tarefas. A gestão por medo baseia-se em ameaça, implícita ou explícita, como forma de envolvimento do empregado no trabalho a exemplo de uma ameaça de retirar a função do empregado ou uma insinuação de que este pode perder o emprego. 
As três formas de gestão citadas são comuns nos bancos e caracterizam o assédio moral organizacional pela sua habitualidade, pelos seus objetivos de instrumentalizar os trabalhadores e aumentar a produtividade, pela degradação física e psicológica que acarreta nos empregados. A CONTRAF observa que os impactos nos trabalhadores iguala o assédio interpessoal e o organizacional, mas este é mais grave por ser generalizado e por permitir que aquele se manifeste mais facilmente. Os bancários creem que os gestores devem ser responsabilizados pessoalmente, mas afirmam que a própria organização é conivente porque propicia, estimula, incentiva, permite que tais práticas ocorram. Faz parte da gestão do trabalho nos bancos a disseminação da injúria, do estresse e do medo.

$\mathrm{O}$ combate à violência organizacional é tão central às entidades sindicais da categoria que o Sindicato dos Bancários de São Paulo, Osasco e Região, em parceria com o Instituto de Defesa do Consumidor (IDEC), publicaram uma cartilha denominada "Venda Responsável de Produtos e Serviços Financeiros", voltada para bancários e clientes. A cartilha anota que as metas impostas pelos bancos são tão absurdas que "levam parte dos consumidores a adquirir produtos que não são necessários ou apropriados ao seu perfil”". Ressalta que, no ano de 2011, os bancos tornaram-se líderes em reclamações ao IDEC pela primeira vez em doze anos, esclarece informações sobre os produtos vendidos e as tarifas cobradas e destaca principalmente a venda casada, que ocorre quando o banco impõe a venda de um título de capitalização como condição para conceder um empréstimo, uma redução de juros ou aumento do limite do cheque especial.

As campanhas nacionais sobre o assédio moral e as metas abusivas, a vasta publicação elaborada pelas entidades sindicais, as denúncias generalizadas feitas pelos bancários começaram a dar resultado em 2010. Neste ano, a Convenção Coletiva Nacional 2010/2011 trouxe uma inovadora Cláusula Quinquagésima Primeira estabelecendo um Protocolo para Prevenção de Conflitos no Ambiente de Trabalho de adesão voluntária dos bancos. A categoria bancária, que foi a primeira a celebrar uma convenção coletiva nacional e a primeira a celebrar uma convenção coletiva de PLR, tornou-se a primeira a celebrar uma convenção coletiva sobre assédio moral, um marco na história do movimento sindical brasileiro.

A Cláusula estabelece como princípios a valorização de todos os empregados, promovendo o respeito à diversidade, à cooperação e o trabalho em equipe, a conscientização destes sobre a importância de um ambiente de trabalho saudável e a promoção de valores éticos, morais e legais. O Parágrafo Primeiro explicita que o objetivo 
do protocolo é promover ações e comportamentos adequados entre os empregados dos bancos aderentes e prevenir conflitos indesejáveis. O Parágrafo Segundo preceitua que os bancos aderentes formalizarão o Protocolo por meio de acordo coletivo com os sindicatos. Os bancos que celebraram os acordos coletivos foram o Itaú, Bradesco, CEF, Santander, HSBC, Safra, City Bank, Votorantim e Bicbanco. Entre as maiores instituições, somente o Banco do Brasil não aderiu por já possuir programa próprio com os mesmos propósitos.

O Acordo Coletivo é enxuto e possui apenas três cláusulas. A Cláusula Primeira apenas define o objeto do ACT, que é a normatização dos termos e condições previstos pela Cláusula Quinquagésima Primeira da CCT 2010/2011. A Cláusula Segunda, em seu caput e Parágrafo Primeiro, ressalta os princípios e objetivos previstos pela CCT. O Parágrafo Segundo estabelece as condições para a prevenção dos conflitos em ambiente de trabalho, que seriam a declaração explícita de condenação a qualquer prática de assédio; a disponibilização, pelo banco, de canal específico de denúncias, reclamações, sugestões e pedidos de esclarecimento pelos empregados; avaliação semestral do programa em reunião das entidades sindicais com a FENABAN, que municiará a reunião com dados estatísticos do programa; a consideração de habilidades comportamentais, de liderança e de relacionamento interpessoal enquanto critérios de promoção para cargos de gestão de pessoas; e a ampla divulgação do instrumento para todos os empregados. O parágrafo Terceiro preceitua que os sindicatos também disponibilizarão canais de denúncias, reclamações, sugestões e pedidos de esclarecimento. O Parágrafo Quarto estabelece os procedimentos a serem adotados. O banco terá 60 dias para apurar a denúncia a partir de sua apresentação devidamente fundamentada. $\mathrm{O}$ empregado poderá denunciar diretamente ao banco ou ao sindicato; neste último caso, o sindicato terá 10 dias para repassar a denúncia ao banco que responderá também ao sindicato. Durante os 60 dias, não poderão ser divulgados os fatos, os denunciantes nem os denunciados. Denúncia anônima só será apurada se feitas diretamente pelo empregado ao banco. O sindicato poderá preservar a identidade do denunciante ao repassar a denúncia ao banco. O Parágrafo Quinto afirma que compete ao sindicato repassar ou não a denúncia. Por fim, a Cláusula Terceira apenas enuncia a duração do ACT de um ano.

A primeira - e, até aqui, única - reunião de avaliação ocorreu em agosto de 2011. Entre fevereiro e junho de 2011, ocorreram 103 denúncias, sendo 65 através dos sindicatos e 38 diretamente realizadas por empregados aos bancos. 69 apurações foram encerradas em 30 de junho, com o reconhecimento, pelos bancos, de situações de assédio em 23. 37 não 
foram consideradas assédio; 9 não foram investigadas pelos bancos sob alegação de não haver elementos suficientes e 34 ainda estavam pendentes de apuração.

Plínio Pavão, ex-secretário de saúde da CONTRAF, afirma que os dados são muito preliminares e não permitem conclusões definitivas sobre o programa. Mas constata que muitos sindicatos não lograram êxito na execução do programa porque os bancários, mormente do setor privado, temem serem identificados e sofrer represálias. Mesmo que a denúncia seja feita ao sindicato e esse preserve a identidade do denunciante, é possível descobrir, pela narração dos fatos, quem denunciou. Por isso, Pavão crê que os sindicatos tem que se mobilizar para dar confiança aos bancários de que não sofrerão qualquer tipo de perseguição caso ofertem uma denúncia.

A despeito da comemoração dos sindicatos pela celebração da CCT, Pavão reconhece que foi uma vitória parcial porque não ataca o problema central que é o assédio organizacional. A CCT, na prática, é um reconhecimento por parte dos bancos da ocorrência de assédio moral em seus ambientes de trabalho e uma conquista por parte dos bancários que colocam tal problema como central em suas campanhas anuais. Porém, os bancos ainda recusam-se a admitir a existência de uma violência organizacional e mantem a mobilização subjetiva dos empregados e a imposição unilateral das metas, ambos elementos conformadores da existência do assédio organizacional nos bancos. É como se os bancos cedessem os anéis para manter os dedos: pune-se gestores, mas mantem-se a estrutura da organização do trabalho que propicia as manifestações de assédio.

Alterar esse quadro levará ainda muito tempo e muita luta por parte dos bancários. Mas a celebração dessa convenção coletiva abre possibilidades e expõe as contradições da organização do trabalho em banco, um avanço que, se bem explorado pelos sindicatos, permitirá atingir o grande objetivo da categoria: a negociação das metas.

Desde 2007, os bancários reivindicam a negociação democrática das metas, mas os bancos recusam peremptoriamente a sequer discutir sob a alegação de que esse tema diz respeito à gestão dos bancos e não cabe ao sindicato discutir. Além disso, afirmam que as metas não são abusivas, são "desafiadoras".

Essas alegações são absurdas porque as metas são o principal fator que ocasionam o assédio moral organizacional e degrada a saúde e a dignidade dos bancários. Pelo conceito de dignidade da pessoa humana associada à figura do empregado subordinado que embase esse trabalho, os bancários tem o direito de negociá-las porque sua dignidade, em nível coletivo, afirma-se pelo direito de ação sindical. Ou seja, a dignidade individual de 
trabalhar com metas razoáveis que não degradem sua saúde e personalidade só se realiza pela dignidade coletiva de negociar as metas.

Nesse sentido apontam todos os profissionais de psicologia e psiquiatria pesquisados por este trabalho. Os profissionais da saúde são unânimes em afirmar que a escuta e a participação dos trabalhadores é essencial para resolver as vivências de sofrimento no trabalho. Sugerem essa via também os bancários consultados pelo maior sindicato do país, cuja expressiva maioria de $69 \%$ apontou a negociação das metas abusivas como o elemento central a ser defendido em campanha nacional da categoria.

A proposta dos bancários quanto às metas é apresentada (e rejeitada!) anualmente. Conforme a minuta de reivindicações do ano de 2010 (CONTRAF, 2010, p. 07), os bancários reivindicam que as metas sejam definidas mediante a participação da categoria e deverá considerar seis aspectos básicos. Primeiro, as metas deverão considerar o porte da unidade (agência ou departamento), a região geográfica, o número de empregados, a carteira de clientes, o perfil econômico do local, a abordagem e o tempo de execução das tarefas. Segundo, as metas serão adequadas e reduzidas proporcionalmente nas hipóteses de afastamentos como licenças, férias, ausências etc. É inacreditável, mas é comum bancários que se afastam temporariamente serem punidos pelo não atingimento das metas. Terceiro, o cumprimento das metas refletirá nas unidades, reduzindo-a proporcionalmente ao seu cumprimento; se a agência bate as metas, o banco aumenta-as no período seguinte, ao invés de reduzi-las. Quarto, fica vedada a comparação de desempenhos mediante rankings. Quinto, as metas serão definidas coletivamente, por unidade, sendo vedada a individualização. E sexto, os bancários que exerçam a função de caixa não serão submetidos ao cumprimento das metas. Estes passam todo o tempo atendendo clientes em seus postos, mas são cobrados como se pudessem ir atrás da clientela.

É preciso frisar aqui que a CEF é o único dos grandes bancos cujas metas não são individuais, porque são atribuídas à agência. A CEF é o quarto maior banco brasileiro e pretende tornar-se o terceiro em 2012, o que demonstra que as reivindicações dos bancários são plenamente viáveis de serem atendidas.

A CONTRAF reivindica também a discussão sobre as remunerações variáveis, outro elemento importante no quadro do assédio organizacional por atrelar o quantum salarial ao desempenho do bancário, amarrando-o aos objetivos da empresa. As regras das remunerações variáveis permanecem obscuras e impostas unilateralmente pelos bancos. Frise-se que os bancos públicos não tem a margem de manobra dos bancos privados para 
alterar a remuneração variável de seus funcionários e não sofrem qualquer prejuízo por isso.

A Convenção Coletiva 2011/2012 trouxe mais uma conquista alvissareira. A Cláusula $35^{\mathrm{a}}$, sobre monitoramento de resultados, veda expressamente a publicação de rankings de desempenho individual dos empregados. Os rankings configuram um recurso largamente utilizado nas agências como mecanismo de pressão por parte dos bancos. Os melhores colocados são pressionados a manter-se nas primeiras posições, normalmente ao custo de seu desgaste físico e mental e de sua vida social; os bancários das colocações inferiores são pressionados pela possibilidade de desemprego ou descomissionamento.

Essa cláusula ataca diretamente um dos principais elementos do assédio moral organizacional. Soma-se ao Protocolo de Prevenção de Conflitos no Ambiente de Trabalho da CCT anterior enquanto conquistas sindicais alentadoras. Nas duas últimas convenções coletivas, os bancários começaram a colher os frutos das campanhas nacionais de combate ao assédio moral organizacional elaboradas desde 2006.

Espera-se mais conquistas que resultem no fim dos instrumentos de gestão baseados na instrumentalização dos bancários com o intuito de atingir os objetivos e metas dos bancos. Instrumentos de gestão calcados em um ambiente de trabalho destrutivo, que degrada a saúde física e psíquica dos empregados. Instrumentos de gestão que agridem a dignidade da pessoa humana, os direitos de personalidade e o direito à saúde.

A categoria bancária é forte e organizada. Suas lutas e conquistas incentivam e trazem esperanças para outros sindicatos. É difícil crer que a Justiça do Trabalho resolva o problema do assédio organizacional, seja por dificuldades processuais e probatórias, seja pela necessária interpretação constitucional que, infelizmente, não é a práxis dos tribunais brasileiros.

A organização sindical bancária tem nas negociações coletivas o palco adequado para afirmar a dignidade dos trabalhadores e acumular forças com vistas à mais ampla, plena e irrestrita liberdade sindical. 


\section{CONCLUSÃO}

O capital financeiro em geral e os bancos em particular adquiriram uma centralidade para a economia como nunca antes vista. $O$ processo de acumulação e enriquecimento desse setor do capitalismo é histórico e vem desde o século XIX, mas adquiriu as proporções dominantes atuais em fins do século XX. Neste início de século XXI, a maioria das mais poderosas empresas globais pertence ao capital portador de juros.

No Brasil, o quadro não é diferente e os bancos tem um espaço de destaque. O país acostumou-se a ver os lucros bancários baterem recordes todos os anos, mesmo em tempos de crise. Boa parte desses lucros fabulosos deve-se ao desenvolvimento econômico e ao acesso aos produtos bancários por milhões de pessoas e empresas. Mas uma parte desses lucros deve-se à superexploração a que são submetidos os trabalhadores bancários.

Os bancos terceirizaram quase metade da força de trabalho bancária de forma absolutamente ilegal e imoral. Estes terceirizados enriquecem os bancos com salários mais baixos, jornada diária mais elástica e sem acesso a uma série de direitos conquistados através das convenções coletivas da categoria. O Estado é em muito responsável por esse quadro: o Poder Executivo por estimular irregularmente a terceirização através dos correspondentes bancários, o Poder Legislativo por manter estruturas sindicais corporativistas que impedem a organização sindical por ramo econômico e o Poder Judiciário por mostrar-se incapaz de aplicar a lei corretamente e dar um fim à situação.

Os empregados bancários diretamente contratados pelos bancos sofrem com formas de gestão "modernas" que lhes oprime e lhes joga sobre os ombros os riscos do negócio. Os lucros absorvidos pelos empregadores são garantidos por metas draconianas e cobranças diárias que atormentam a categoria. O resultado é um quadro dramático onde as lesões por esforço repetitivo mantem-se em níveis altíssimos, mas perdem o predomínio das patologias entre os bancários para as lesões mentais. Estresse, depressão, insônia, suicídio. Trabalhar em um banco significa enfrentar um dos mais poderosos conglomerados econômicos brasileiros e arcar com as consequências.

Quando essa dissertação encontrava-se em vias de conclusão, três fatos ocorriam simultaneamente de forma alentadora.

Primeiro, o governo federal iniciou um processo de enfrentamento direto com os bancos como não se tem notícia na história recente. Por pressão do Palácio do Planalto, o 
Banco Central implementou sucessivas quedas da taxa de juros que já atingiram o nível mais baixo de sua história. A partir disso, os grandes bancos públicos acompanharam a tendência e promoveram uma queda geral em suas taxas de juros, o que encontrou resistência inicial por parte dos bancos privados, mas estes foram obrigados a ceder sob pena de perda de mercado. O atual presidente do Banco Central é um servidor público de carreira, sendo o primeiro presidente do BC não oriundo de instituições financeiras privadas. Esses fatos sugerem que o Banco Central do Brasil tornou-se independente de fato: independente do mercado financeiro.

Segundo, a CONTRAF anunciou que prepara uma proposta ao governo federal para que convoque uma conferência nacional do sistema financeiro, à semelhança das dezenas de conferências temáticas que discutem políticas públicas. A CONTRAF entende que os bancos são concessões públicas e seu papel não pode objeto de deliberação restrita aos seus interesses privados. A entidade propõe que os bancos deveriam ter metas sociais que garantam juros baixos à sociedade, condições dignas de trabalho e ampliação do acesso de seus produtos - mais de 2.000 municípios brasileiros não possuem uma agência bancária sequer. Ao propor essa conferência, a categoria bancária aponta caminhos de controle social sobre a propriedade privada, que tem função social prevista pela Constituição. Uma conferência nacional do setor traria publicidade aos problemas enfrentados pelos trabalhadores bancários e pela sociedade em relação aos bancos.

Terceiro, um bancário foi indicado para assumir a presidência da CUT em seu $11^{\circ}$ Congresso Nacional a ser realizado em julho de 2012. Será a primeira vez que a maior central sindical da América Latina será presidida por um empregado bancário, o que demonstra que a categoria consolida-se como uma das mais importantes do movimento sindical brasileiro e de experiências mais avançadas.

Esses três fatos combinados apontam para a contestação do domínio do capital portador de juros sobre a sociedade e do assédio moral em caráter organizacional que impõe sobre seus empregados. Após décadas de hegemonia do capital financeiro e de ataques à dignidade, à personalidade e à saúde dos trabalhadores bancários, a sociedade brasileira e os sindicatos da categoria parecem ter acumulado forças suficientes para virar o jogo. As campanhas nacionais contra o assédio organizacional dos bancários e suas conquistas expressadas nas recentes convenções coletivas começam a dar resultados. É nesse contexto que essa dissertação foi elaborada. 
O presente trabalho dividiu-se em três partes. Na primeira, analisou-se o fenômeno do assédio moral observado inicialmente pelas ciências do trabalho e absorvido posteriormente pelo Direito. Viu-se que o instituto do assédio, mormente em nível organizacional, é plenamente repelido pelo Direito pátrio a despeito da inexistência de uma lei própria, o que dificulta o seu combate no Poder Judiciário. A interpretação sistemática do Direito Constitucional, Civil, Trabalhista e Previdenciário protegem os bens jurídicos fundamentais atacados pelo assédio organizacional: a dignidade da pessoa humana e seus consequentes direitos da personalidade e da saúde do trabalhador.

$\mathrm{Na}$ segunda parte, analisou-se como o capital bancário desenvolve-se a partir do desenvolvimento geral da economia e submete esta aos seus desígnios. O duplo negativo deste segmento do capital é o trabalho bancário, cujas técnicas de gestão e dominação baseiam-se em medo, injúria, estresse. Observou-se informações quantitativas e qualitativas de como a organização dos recursos humanos dos bancos degradam a saúde física e mental de seus empregados, originando um quadro de adoecimento generalizado e, em casos extremos, de índices elevados de suicídio. A questão central aqui é o sistema de avaliação quantofrênica baseado em metas abusivas e a redução dos indivíduos a números produzidos que desconsideram a humanidade dos trabalhadores em detrimento de lucros.

A terceira parte é uma crítica à manutenção, pela Carta Magna, dos elementos fundamentais da estrutura corporativista que amarram os sindicatos e impedem a sua livre organização e atuação. A Constituição Federal de 1988 é uma expressão da vontade geral pela democracia, mas manteve o espírito autoritário da CLT no que tange às amarras à liberdade sindical, ferindo de morte a dignidade da pessoa humana associada à figura do trabalho subordinado. Analisou-se a organização sindical bancária e as conquistas vanguardistas obtidas pela categoria através das negociações coletivas e de suas convenções coletivas nacionais para mostrar que a urgente e necessária democratização das relações entre capital e trabalho é o caminho mais adequado a resolver os conflitos. É isso o que afirma a doutrina do Direito do Trabalho. É isso o que preceitua a OIT.

Essa dissertação é fruto das experiências individuais do seu autor, que já trabalhou com quatro sindicatos de quatro categorias diversas, associadas às teorizações produzidas pela Faculdade de Direito da Universidade de São Paulo e às sínteses da ação prática das entidades sindicais bancárias, uma vez que o autor trabalhou no Sindicato dos Bancários do $\mathrm{ABC}$, onde este projeto foi desenvolvido. 
Os objetivos dessa pesquisa foram denunciar a situação de assédio moral organizacional que existe nos bancos e defender enfaticamente a liberdade sindical, liberdade essa incompatível com o ordenamento jurídico brasileiro. A acumulação de capital exorbitante realizada anualmente pelos bancos tem-se baseado na máxima exploração da sociedade brasileira, que arca com altíssimas taxas de juros que entravam seu desenvolvimento, e na máxima exploração da força de trabalho bancária, mobilizada subjetiva e objetivamente para o cumprimento de metas de produtividade unilaterais de dramático impacto no corpo e na mente dos bancários.

Frente à incapacidade dos poderes públicos em resolver o quadro de degradação física e psíquica dos empregados dos bancos, cabe a estes resolverem este quadro a partir de sua luta coletivamente organizada. É fundamental que o Brasil reforme sua legislação trabalhista que bloqueia o fortalecimento dos trabalhadores para que estes conquistem de fato a dignidade negada pela mesma Constituição que a preceitua. A organização sindical bancária tem a tarefa de acabar com a superexploração dos bancos para com a sua força de trabalho. Fazendo-o, os bancários acabam também com a superexploração dos bancos para com a sociedade brasileira.

Essa dissertação é uma defesa da mais ampla, plena e irrestrita liberdade sindical. 


\section{REFERÊNCIAS BIBLIOGRÁFICAS}

ACERTE PESQUISA E COMUNICAÇÃO. Pesquisa: O Impacto da Organização e do Ambiente de Trabalho Bancário na Saúde Física e Mental da Categoria. Pesquisa realizada entre novembro de 2010 e janeiro de 2011, gentilmente cedida pela CONTRAF.

ACORDO ADITIVO PARA PREVENÇÃO DE CONFLITOS NO AMBIENTE DE TRABALHO. Disponível em www.contrafcut.org.br. Acesso em 13/06/2012.

BARACAT, Eduardo Milléo. A Boa-Fé no Direito Individual do Trabalho. São Paulo, 2003, LTR.

BARRETO, Margarida. Violência, Saúde e Trabalho (Uma Jornada de Humilhações). São Paulo, 2006, Editora da PUC-SP.

BOUYER, Gilbert Cardoso. Entre o Número e a Vivência: Qual Ergonomia Praticar? In SZNELWAR, Laerte Idal (Org.). Saúde dos Bancários. São Paulo, 2011, Publisher Brasil, p. $187-206$.

BRANDÃO, Andréa Gonçalves, HORTA, Bernardo Lessa, TOMASI, Elaine. Sintomas de Distúrbios Osteomusculares em Bancários de Pelotas e Região: Prevalência e Fatores Associados. In ASSOCIAÇÃO BRASILEIRA DE SAÚDE COLETIVA (ABRASCO). Revista Brasileira de Epidemiologia, vol. 8. São Paulo, 2005, ABRASCO, p. 295 - 305.

BRUNO, Walcir Previtale. Bancários não são Máquinas. In SZNELWAR, Laerte Idal (Org.). Saúde dos Bancários. São Paulo, 2011, Publisher Brasil, p. 21 - 32.

CAHALI, Yussef Said. Dano Moral. São Paulo, 2005, Editora Revista dos Tribunais.

CARVALHO Neto, Antônio Moreira de. Liberdade e Autonomia Sindical no Brasil: Meio Século de Atraso na Aplicação da Convenção No 87 da OIT. In Organização Internacional 
do Trabalho (Org.). Reforma Sindical e Negociação Coletiva. Brasília, 2001, OIT, p. 67 80.

CASTRO, Maria Sílvia Portella. Opções Estratégicas de Organização dos Sindicatos de Trabalhadores. In Organização Internacional do Trabalho (Org.). Reforma Sindical $e$ Negociação Coletiva. Brasília, 2001, OIT, p. 107 - 130.

CHESNAIS, François. A Finança Mundializada. São Paulo, 2011, Boitempo Editorial.

COELHO, Fábio Ulhoa. Curso de Direito Comercial - Direito de Empresa, volume 1. São Paulo, 2009, Editora Saraiva.

CONFEDERAÇÃO NACIONAL DOS TRABALHADORES DO RAMO FINANCEIRO

- CONTRAF-CUT. Assédio Moral, Violência Organizacional e Metas Abusivas. In Cadernos, nº 01. São Paulo, 2010, Bangraf.

Revista dos Bancários. São Paulo, 2008, Bangraf.

Terceirização no Sistema Financeiro. In Terceirização no Brasil - Do Discurso da Inovação à Precarização do Trabalho (Atualização do Debate e Perspectivas). São Paulo, 2009, Annablume Editora.

CONVENÇÃO COLETIVA DOS BANCÁRIOS 2010/2011. Disponível em www.bancariosabc.org.br. Acesso em 13/06/2012.

CONVENÇÃO COLETIVA DOS BANCÁRIOS 2011/2012. Disponível em www.bancariosabc.org.br. Acesso em 13/06/2012.

CORREIA, Marcus Orione Gonçalves. Interpretação dos Direitos Fundamentais Sociais, Solidariedade e Consciência de Classe. In CANOTILHO, J. J., CORREIA, Marcus Orione 
Gonçalves, CORREIA, Érica Paula Barcha (Orgs.) Direitos Fundamentais Sociais. São Paulo, 2010, Editora Saraiva.

COUTINHO, Grijalbo Fernandes. Terceirização Bancária no Brasil - Direitos Humanos Violados pelo Banco Central. São Paulo, 2011, LTR.

CRIVELLI, Ericson. Democracia Sindical no Brasil. São Paulo, 2000, LTR.

Direito Internacional do Trabalho Contemporâneo. São Paulo, 2010, LTR.

Modelo Corporativo no Brasil - Ensaio para uma Teoria de Transição. In Organização Internacional do Trabalho (Org.). Reforma Sindical $e$ Negociação Coletiva. Brasília, 2001, OIT, p. 131 - 146.

DELGADO, Mauricio Godinho. Curso de Direito do Trabalho. São Paulo, LTR, 2007.

DEJOURS, Christophe. A Avaliação do Trabalho Submetida à Prova do Real-Crítica aos Fundamentos da Avaliação. Cadernos de TTO nº 2. São Paulo, 2008, Editora Blucher.

DEPARTAMENTO INTERSINDICAL DE ESTATÍSTICA E ESTUDOS SOCIOECONÔMICOS - DIEESE. A Situação do Trabalho no Brasil na Primeira Década dos Anos 2000. São Paulo, 2012b, DIEESE.

. Balanço das Greves em 2009 e 2010. São Paulo, 2012.

Disponível em www.dieese.org.br . Acessado em 06/06/2012a.

. Desempenho dos Cinco Maiores Bancos em 2011. 2011a. Disponível em www.dieese.org.br. Acessado em 16/03/2012.

. Fusão no Setor Bancário - Emprego e Concorrência. 2007, disponível em www.dieese.org.br. Acessado em 23/03/2012. 
Pesquisa de Emprego Bancário. 2011b, Disponível em www.dieese.org.br. Acessado em 23/03/2012.

DINIZ, Maria Helena. Curso de Direito Civil Brasileiro - Teoria Geral do Direito Civil. São Paulo, 2009, Editora Saraiva.

DURANTI, Cláudia Maria Beatriz S. Vantagens e Desvantagens da Ratificação pelo Brasil da Convenção No 87 da OIT. In Organização Internacional do Trabalho (Org.). Reforma Sindical e Negociação Coletiva. Brasília, 2001, OIT, p. 37 - 48.

EBERLE, André Davi, SOBOLL, Lis Andréa Pereira, HORST, Ana Carolina. Avaliação Comparativa de Resultados e Assédio Moral Organizacional: Concorrência Generalizada, Individualismo e Adoecimento no Trabalho. In MENDES, Ana Magnólia, MERLO, Álvaro Roberto Crespo, MORRONE, Carla Faria, FACAS, Emílio Peres (Orgs.). Psicodinâmica e Clínica do Trabalho: Temas, Interfaces e Casos Brasileiros. Curitiba, 2010, Juruá, p. 519 - 535.

FARIA, Glauco. O Governo Lula e o Novo Papel do Estado Brasileiro. Brasil em Debate, volume 3. São Paulo, 2010, Editora Perseu Abramo.

FEDERAÇÃO BRASILEIRA DOS BANCOS - FEBRABAN. Balanço Social dos Bancos. 2003, disponível em www.febraban.org.br, acessado em 23/13/12.

- O Setor Bancário em

Números. 2011, disponível em www.febraban.org.br, acessado em 23/03/2012.

- Relatório Anual 2010.

2010, disponível em www.febraban.org.br, acessado em 23/03/2012.

FILHO, Rodolfo Pamplona. O Dano Moral na Relação de Emprego. São Paulo, 1998, LTR. 
FREITAS, Maria de Ester, HELOANI, Roberto, BARRETO, Margarida. Assédio Moral no Trabalho. Coleção Debates em Administração. São Paulo, 2009, Cengage Learning.

FREITAS Jr., Antônio Rodrigues de. Vantagens, Desvantagens e Implicações da Convenção $\mathrm{N}^{\circ} 87$ da OIT para as Relações de Trabalho no Brasil. In Organização Internacional do Trabalho (Org.). Reforma Sindical e Negociação Coletiva. Brasília, 2001, OIT, p. 49 - 54.

FRENCH, John D. Afogados em Leis - A CLT e a Cultura Política dos Trabalhadores Brasileiros. São Paulo, 2001, Fundação Perseu Abramo.

GAULEJAC, Vincent de. Gestão como Doença Social - Ideologia, Poder Gerencialista e Fragmentação Social. Aparecida, 2007, Editora Idéias e Letras.

GENRO, Tarso Fernando. Direito Individual do Trabalho. São Paulo, 1994, LTR. Contribuição à Crítica do Direito Coletivo do Trabalho. Porto Alegre, sem data informada, Síntese.

GOSDAL, Thereza Cristina. Dignidade do Trabalhador - Um Conceito Constituído sob o Paradigma do Trabalho Decente e da Honra. São Paulo, 2007, LTR.

, SOBOLL, Lis Andrea Pereira (Org.). Assédio Moral Interpessoal e Organizacional. São Paulo, 2009, LTR.

GUEDES, Marcia Novaes. Terror Psicológico no Trabalho. São Paulo, 2008, LTR.

GUILHOT, Nicolas. Uma Galeria de Criminosos Respeitável. In Le Monde Diplomatique Brasil, Dossiê 08 - Crise Bancária, o Roubo do Século. São Paulo, 2011, Instituto Pólis, p. $9-16$.

HALIMI, Serge. Depois de Tobin. Le Monde Diplomatique Brasil, Ano 5, $\mathrm{n}^{\circ}$ 5, fevereiro 2012. São Paulo, Instituto Pólis, 2012. 
HIRIGOYEN, Marie-France. Assédio Moral - A Violência Perversa no Cotidiano. Rio de Janeiro, 2009, Bertrand Brasil.

. Mal-Estar no Trabalho - Redefinindo o Assédio Moral. Rio de Janeiro, 2010, Bertrand Brasil.

HUBAULT, François. Os Desafios Relacionados à Mobilização da Subjetividade na Relação de Serviço. In SZNELWAR, Laerte Idal (Org.). Saúde dos Bancários. São Paulo, 2011, Publisher Brasil, p. 125 - 150.

JINKINGS, Nise. O Mister de Fazer Dinheiro - Autonomização e Subjetividade do Trabalho Bancário. São Paulo, 1996, Boitempo Editorial.

Trabalho e Resistência na Fonte Misteriosa - Os Bancários no Mundo da Eletrônica e do Dinheiro. Campinas, 2002, Editora da UNICAMP.

LAZEAR, Edward P. Personnel Economics. Massachussets, 1995, The MIT Press.

LENIN, Vladimir Ilich Ulianov. Sobre os Sindicatos. São Paulo, 1979, Editorial Livramento.

LENINE, V. L.. O Imperialismo - Fase Superior do Capitalismo. São Paulo, 2008, Centauro.

MAENO, Maria. LER e Transtornos Psíquicos Relacionados ao Mundo do Trabalho: Faces de Uma Mesma Moeda. In SZNELWAR, Laerte Idal (Org.). Saúde dos Bancários. São Paulo, 2011, Publisher Brasil, p. 207 - 300.

MAGANO, Octávio Bueno. Implicações da Convenção Nº 87 da OIT Para as Relações de Trabalho no Brasil. In Organização Internacional do Trabalho (OIT). Reforma Sindical e Negociação Coletiva. Brasília, 2001, OIT, p. 17 - 22. 
MAIOR, Jorge Luiz Souto. Breves Considerações sobre a História do Direito do Trabalho no Brasil. In CORREIA, Marcus Orione Gonçalves (Org.). Curso de Direito do Trabalho, vol. I - Teoria Geral do Direito. São Paulo, 2007, LTR.

Fundamentos para a Solução dos Conflitos Coletivos de Trabalho. In MAIOR, Jorge Luiz Souto, CORREIA, Marcus Orione Gonçalves. Curso de Direito do Trabalho - Volume III, Direito Coletivo do Trabalho, Coleção Pedro Vital Neto. São Paulo, 2008, LTR, p. 98 - 107.

MARGIN Call - O Dia antes do Fim. Produzido por Robert Ogden Barnum, Michael Benaroya, Neal Dodson, Joe Jenckes, Corey Moosa, Zazhary Quinto. Dirigido por J. C. Chandor. Paris Filmes (109 min.). EUA, 2011.

MARX, Karl. O Capital - Crítica da Economia Política. Livro 3, volume 5: O Processo Global de Produção Capitalista. Rio de Janeiro, 2008, Civilização Brasileira.

MENDES, Ana Magnólia, MERLO Álvaro Roberto Crespo, MORRONE, Carla Faria, FACAS, Emílio Peres (Org.). Psicodinâmica e Clínica do Trabalho - Temas, Interfaces e Casos Brasileiros. Curitiba, 2010, Editora Juruá.

MENDES, Ana Magnólia, ARAÚJO, Luciane. Os Modelos de Avaliação de Desempenho. In REGO, Vitor Barros (Org.). Adoecimento Psíquico no Trabalho Bancário: da Prestação de Serviços à (De)Pressão por Vendas. Brasília, 2011, Editora Ex Libris, p. 87 - 112.

MORAES, Evaristo de. Apontamentos de Direito Operário. São Paulo, 1998, LTR.

NASCIMENTO, Amauri Mascaro. Curso de Direito do Trabalho. São Paulo, 2009, Editora Saraiva.

SALOMÃO Neto, Eduardo. Direito Bancário. São Paulo, 2011, Editora Atlas.

OLIVEIRA, Paulo Eduardo Vieira. Negociação Coletiva. In MAIOR, Jorge Luiz Souto, CORREIA, Marcus Orione Gonçalves. Curso de Direito do Trabalho - Volume III, 
Direito Coletivo do Trabalho, Coleção Pedro Vital Neto. São Paulo, 2008, LTR, p. 108 128.

.O Dano Pessoal no Direito do Trabalho. São Paulo,

2010, LTR.

, CERQUEIRA, Vinicius da Silva. Relações de

Trabalho, Justiça e Democracia. In Revista dos Tribunais, vol. 918. São Paulo, 2012, Editora Revista dos Tribunais, p. $571-590$.

OLIVEIRA, Sebastião Geraldo de. Proteção Jurídica à Saúde do Trabalhador. São Paulo, 2010, LTR.

PAVÃO, Plinio. La Lucha de los Sindicatos de Bancários de Brasil contra el Acoso Moral. Artigo ainda não publicado, gentilmente cedido pelo camarada.

PLIHON, Dominique. Pobres Normas Internacionais. In Le Monde Diplomatique Brasil, Dossiê 08 - Crise Bancária, o Roubo do Século. São Paulo, 2011, Instituto Pólis, p. 29 31.

RAINHO, Luís Flávio, BARGAS, Osvaldo Martines. As Lutas Operárias e Sindicais dos Metalúrgicos em São Bernardo (1977 - 1979). São Bernardo do Campo, 1983, FG.

REGO, Vitor Barros. A Qualidade Total. In REGO, Vitor Barros (Org.). Adoecimento Psíquico no Trabalho Bancário: da Prestação de Serviços à (De)Pressão por vendas. Brasília, 2011a, Editora Ex Libris, p. 77 - 86.

As Práticas de Marketing Interno nos Bancos. In REGO, Vitor

Barros. Adoecimento Psíquico no Trabalho Bancário: da Prestação de Serviços à (De)Pressão por vendas. Brasília, 2011b, Editora Ex Libris, p. 65 - 76. 
As Práticas Neoliberais. In REGO, Vitor Barros. Adoecimento

Psíquico no Trabalho Bancário: da Prestação de Serviços à (De)Pressão por vendas. Brasília, 2011c, Editora Ex Libris, p. 51 - 64.

Adoecimentos Relacionados ao Trabalho: Estudo de Casos. In

REGO, Vitor Barros. Adoecimento Psíquico no Trabalho Bancário: da Prestação de Serviços à (De)Pressão por vendas. Brasília, 2011d, Editora Ex Libris, p. 179 - 248.

RIMBERT, Pierre. Arquitetos de Ruínas. In Le Monde Diplomatique Brasil, Dossiê 08 Crise Bancária, o Roubo do Século. São Paulo, 2011, Instituto Pólis, p. 6 - 7.

RODRIGUES, Iram Jácome. Sindicalismo e Política - A Trajetória da CUT (1983 a 1993). São Paulo, 2011, LTR.

RODRIGUES, Suzineide, MACIELA, Regina Heloisa, BITU, Francisco Gonzaga, SARAIVA, Luís, HORA, Andrea da. Assédio Moral no Trabalho Bancário: Impactos sobre a Saúde e sua Relação com Gênero e Raça. Pesquisa realizada em 2006 gentilmente cedida pela CONTRAF.

ROMITA, Arion Sayão. Liberdade Sindical no Brasil: A Ratificação da Convenção No 87 da OIT. In Organização Internacional do Trabalho (Org.). Reforma Sindical e Negociação Coletiva. Brasília, 2001, OIT, p. 23 - 36.

ROSSI, Elisabeth Zumira. Análise Clínica da Organização do Trabalho Bancário e o processo de adoecimento por LER/DORT. In MENDES, Ana Magnólia, MERLO, Álvaro Roberto Crespo, MORRONE, Carla Faria, FACAS, Emílio Peres (Orgs.). Psicodinâmica e Clínica do Trabalho: Temas, Interfaces e Casos Brasileiros. Curitiba, 2010, Juruá, p. 381 396.

SADER, Eder. Quando Novos Personagens Entraram em Cena - Experiências e Lutas dos Trabalhadores da Grande São Paulo 1970 - 1980. São Paulo, 2010, Paz e Terra.

SADY, João José. Curso de Direito Sindical. São Paulo, 1998, LTR. 
SANTOS, Marcelo Augusto Finazzi. Patologia da Solidão: o Suicídio de Bancários no Contexto da Nova Organização do Trabalho. Dissertação de Mestrado defendida perante a Faculdade de Economia, Administração, Contabilidade e Ciências da Informação da Universidade de Brasília. Brasília, 2009. Disponível em www.unb.br.

SANTOS, Ronaldo Lima dos. Teoria das Normas Coletivas. São Paulo, LTR, 2009.

SARLET, Ingo Wolfgang. Dignidade da Pessoa Humana e Direitos Fundamentais na Constituição Federal de 1988. Porto Alegre, 2010, Livraria do Advogado.

SILVA, Jair Batista da. A Face Privada de um Banco Público: Os Experimentos Flexíveis do Banco do Brasil. In ANTUNES, Ricardo (Org.). Riqueza e Miséria do Trabalho no Brasil. São Paulo, 2009, Boitempo Editorial, p. 207 - 236.

SILVA, José Afonso da. Curso de Direito Constitucional Positivo. São Paulo, 2007, Malheiros.

SILVA, Otávio Pinto e. A Questão da Liberdade Sindical. In MAIOR, Jorge Luiz Souto, CORREIA, Marcus Orione Gonçalves. Curso de Direito do Trabalho - Volume III, Direito Coletivo do Trabalho. Coleção Pedro Vidal Neto. São Paulo, LTR, 2008, p. 66 - 85.

SILVA, Vinicius da. Sobre o Projeto (ACE) dos Metalúrgicos do ABC. Disponível em www.smabc.org.br, acesso em 11/06/2012.

SIMÃO, Azis. Sindicato e Estado. São Paulo, 1981, Editora Ática.

SIMÓN, Sandra Lia. A Proteção Constitucional da Intimidade e da Vida Privada do Empregado. São Paulo, 2000, LTR.

SINDICATO DOS BANCÁRIOS DO ABC. Revista dos Bancários do ABC. 2012, Quanta Editora. 
- Trabalho + Saúde = Qualidade de Vida.

Informativo da Secretaria de Saúde e Condições de Trabalho.

SINDICATO DOS BANCÁRIOS E FINANCIÁRIOS DE SÃO PAULO, OSASCO E REGIÃO. Participação dos Trabalhadores Bancários nos Lucros e Resultados - Balanço e Perspectivas (1995 - 2011). São Paulo, 2011, Bangraf.

- Metas + Saúde. In Folha Bancária, no 61. São Paulo, 2012, Bangraf.

. Cartilha Assédio Moral-Denuncie. São Paulo.

. Cartilha - Metas + Saúde. São Paulo, Bangraf.

, INSTITUTO BRASILEIRO DE DEFESA DO CONSUMIDOR (IDEC). Venda

Responsável de Produtos e Serviços Financeiros. São Paulo, Bangraf.

SINDICATO DOS METALÚRGICOS DO ABC, SINDICATO DOS METALÚRGICOS DE TAUBATÉ, SINDiCATO DOS METALÚRGICOS DE SOROCABA E REGIÃO, SINDICATO DOS METALÚRGICOS DE SALTO. Acordo Coletivo Especial (ACE). Gráfica Simetal.

SIQUEIRA Neto, José Francisco. Liberdade Sindical e Representação dos Trabalhadores nos Locais de Trabalho. In Organização Internacional do Trabalho (Org.). Reforma Sindical e Negociação Coletiva. Brasília, 2001, OIT, p. 81 - 106.

SOUSA JR., José Geraldo de. Movimentos Sociais - Emergência de Novos Sujeitos: O Sujeito Coletivo de Direito. In: SOUTO, Cláudio; FALCÂO, Joaquim (Orgs.). Sociologia e Direito: Textos Básicos para a Disciplina Sociologia Jurídica. $2^{\text {a }}$ Ed. São Paulo, 1999, Editora Pioneira, p. 255 - 263. 
SOUZA, Samuel Fernando de. "Batismo de Fogo": O Ministério do Trabalho e o Controle Sindical nos anos 1930. In Perseu - História, Memória e Política. № 2, Ano 2. São Paulo, 2008, Fundação Perseu Abramo, p. 177 - 202.

SZNELWAR, Laerte Idal, PEREIRA, Luciano. Trajetórias de Trabalhadores Bancários Entre o Sonho e o Real do Sofrimento. In SZNELWAR, Laerte Idal (Org.). Saúde dos Bancários. São Paulo, 2011, Publisher Brasil, p. 45 - 62.

SÜSSEKIND, Arnaldo. Direito Constitucional do Trabalho. Rio de Janeiro, 2010, Renovar.

TEIXEIRA, Gilnei Mourão. Liberdade Sindical no Brasil: Uma Visão Estratégica. In Organização Internacional do Trabalho (Org.). Reforma Sindical e Negociação Coletiva. Brasília, 2001, OIT, p. 55 - 66.

TERTRE, Christian Du. Bancos e Produtividade: Entre Dinâmica Industrial e Serviçal?. In SZNELWAR, Laerte Idal (Org.). Saúde dos Bancários. São Paulo, 2011, Publisher Brasil, p. $63-82$.

TRABALHO Interno (Inside Job). Produzido por Charles Ferguson e Audrey Marrs. Dirigido por Charles Ferguson. Sony Pictures Classics. DVD (109 min.). EUA, 2010. 


\section{ANEXOS}

Anexo I - Roteiro da entrevista com os bancários

Qual a sua idade atual e a que ingressou no banco?

Qual a sua escolaridade atual e a que ingressou no banco?

Qual o seu cargo atual e os anteriores?

Como se dá o marketing interno do banco?

O que você entende por serviço de excelência?

Você acha que o trabalho no banco é mais intenso e estressante do que os demais?

Como eram distribuídas as metas?

Você acha que suas metas eram justas e realizáveis ou abusivas?

Como se dava a cobrança pelo cumprimento das metas?

Que sentimentos essa cobrança lhe despertava?

Você acha que as condições de trabalho no banco favoreciam o desenvolvimento de doenças?

O que o banco fazia para amenizar o problema?

Você teve algum problema de saúde físico ou psíquico por causa do trabalho no banco?

Qual foi a sua reação diante do problema?

Como isso lhe prejudicou?

Qual avaliação global você faz do trabalho em banco? Benefícios x malefícios? 
Anexo II - Roteiro da entrevista com os gestores

Quais mecanismos de mobilização subjetiva dos empregados são utilizados para manter os empregados motivados e produtivos?

O que o banco entende por serviço de excelência?

Como o banco organiza o seu marketing interno?

Em um setor da economia de alta rotatividade da mão-de-obra, o que o banco faz para manter os seus empregados?

Qual o perfil do bancário que o banco busca atualmente?

Quais mecanismos de avaliação de desempenho individual e coletivo são utilizados pelo banco?

Como é organizada a distribuição das metas de desempenho? Por pessoa? Por unidade? Por região?

Como são organizados os rankings de desempenho?

Há premiações aos mais produtivos e/ou punições aos menos produtivos?

Em sua avaliação, a categoria bancária é mais pressionada que outras categorias de trabalhadores?

O trabalho em banco é mais intenso e/ou estressante que outras categorias?

Em sua avaliação, o trabalho em banco pode prejudicar a saúde dos empregados?

O banco tem alguma preocupação especial com a saúde física e/ou psíquica dos seus empregados? O que o banco faz para amenizar a situação?

Como o banco acha que é visto por seus empregados? Como o banco gostaria de ser visto por seus empregados? 